\author{
UNIVERSIDADE DE SÃO PAULO \\ ESCOLA DE ENGENHARIA DE SÃO CARLOS \\ DEPARTAMENTO DE ENGENHARIA DE ESTRUTURAS
}

MARGOT FABIANA PEREIRA

Análise experimental e numérica de pilares mistos parcialmente revestidos 



\section{MARGOT FABIANA PEREIRA}

\section{Análise experimental e numérica de pilares mistos parcialmente revestidos}

\section{VERSÃO CORRIGIDA}

A versão original encontra-se na Escola de Engenharia de São Carlos

Dissertação apresentada à Escola de Engenharia de São Carlos da Universidade de São Paulo, como parte dos requisitos para a obtenção do Título de Mestre em Ciências, Programa de Engenharia Civil (Estruturas).

Orientadora: Prof. . Associada Ana Lúcia Homce de Cresce El Debs. 
AUTORIZO A REPRODUÇ̃̃ TOTAL OU PARCIAL DESTE TRABALHO, POR QUALQUER MEIO CONVENCIONAL OU ELETRÔNICO, PARA FINS DE ESTUDO E PESQUISA, DESDE QUE CITADA A FONTE.

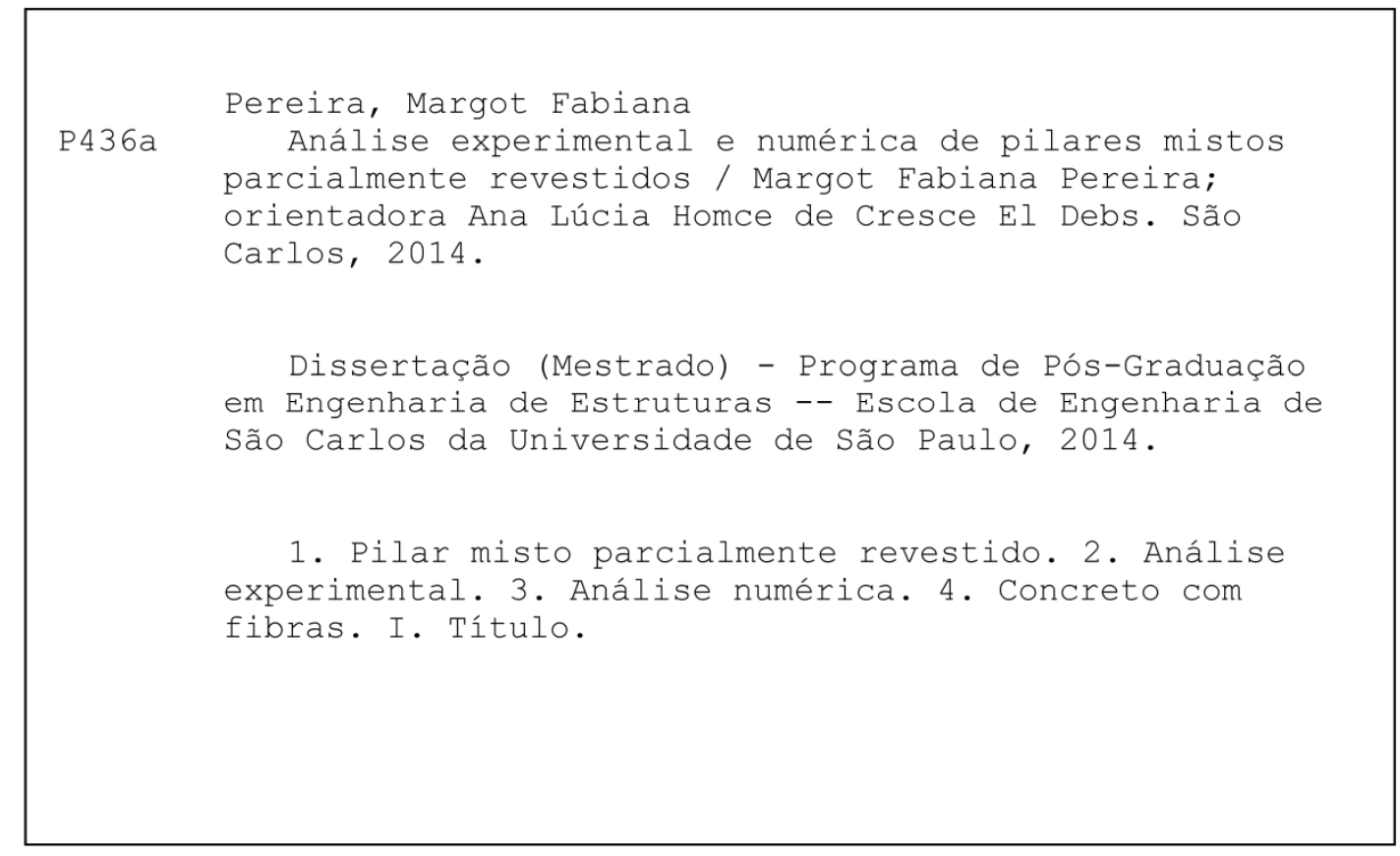




\section{FOLHA DE JULGAMENTO}

Candidata: Engenheira MARGOT FABIANA PEREIRA.

Título da dissertação: "Análise experimental e numérica de pilares mistos parcialmente revestidos".

Data da defesa: 28/02/2014

\section{Comissão Julgadora:}

Resultado:

Profa. Associada Ana Lúcia Homce de Cresce El Debs (Orientadora) APROV ADA (Escola de Engenharia de São Carlos/EESC)

Prof. Dr. Leandro Mouta Trautwein

APROVAOA

(Universidade Estadual de Campinas/UNICAMP)

Profa. Dra. Silvana De Nardin

APROVADA

(Universidade Federal de São Carlos/UFSCar)

Coordenadora do Programa de Pós-Graduação em Engenharia Civil (Engenharia de Estruturas):

Profa. Associada Ana Lucia Homce de Cresce El Debs

Presidente da Comissão de Pós-Graduação:

Prof. Titular Denis Vinicius Coury 

Á minha querida avó, Maria da Conceição (†) 



\section{Agradecimentos}

A Deus, pelas belas oportunidades de aprendizado que colocou em meu caminho...

À minha avó, que apesar de todas as dificuldades da vida, soube a seu modo me dar as diretrizes para a vida.

Aos meus pais, Mario e Delma, pelo apoio, dedicação e amor incondicional.

Às mães emprestadas que a vida me deu, entre elas Bianca Ozório.

Aos meus queridos irmãos, Mario e Mayara, pelo companheirismo e conversas bobas que alegravam os finais de tarde.

Ao Marcelo Masiero pelo carinho, paciência e compreensão.

À minha Orientadora, Professora Ana Lúcia H. C. El Debs, pela paciência e apoio indispensável. Por ser mais que uma orientadora, um modelo.

Às amigas, Suzane Pigossi, Talita Schiavon e Ana Karolina, pelos conselhos e compreensão que nem o tempo e a distância modificam.

Ao Matheus Fernandes, pela ajuda com o programa computacional DIANA.

Ao Hidelbrando José F. Diógenes pela solicitude em me auxiliar na dissertação e artigos desenvolvidos.

Aos amigos que conquistei no decorrer do trabalho, em especial, Paulo Vitorio, Pablo Krahl, Gabriela Fernandes, Gisele Martins e Diôgo Oliveira.

Aos professores e funcionários do Departamento de Estruturas pela ajuda recebida em vários momentos.

Aos técnicos do Laboratório de Engenharia de Estruturas pela dedicação na realização do programa experimental

À CAPES pelo financiamento das primeiras bolsas de mestrado.

À FAPESP pela bolsa de estudos e auxílio financeiro. 

“A evolução é a transição do ser da condição de escravo à condição de senhor do próprio destino."

\section{Lameira de Andrade}





\section{RESUMO}

PEREIRA, M. F. (2014). Análise Experimental e Numérica de Pilares Mistos de Aço e Concreto. Dissertação (Mestrado) - Escola de Engenharia de São Carlos, Universidade de São Paulo, São Carlos, 2014.

O pilar misto parcialmente revestido é fruto da associação de um perfil metálico e concreto trabalhando em conjunto. Nestes pilares o perfil metálico, normalmente perfil I ou H, não é totalmente envolvido por concreto, sendo apenas a região entre as mesas preenchida. No Brasil, a utilização de pilares mistos parcialmente revestidos é ainda incipiente. Contudo a introdução do dimensionamento de elementos mistos na ABNT - NBR 8800:2008 e as vantagens construtivas inerentes aos elementos mistos tem viabilizado a utilização destes elementos em obras pelo país afora, especialmente naquelas de grande porte. Neste contexto, o objetivo principal do trabalho é analisar o comportamento estrutural destes pilares e avaliar a possibilidade de substituição das armaduras tradicionais compostas por vergalhões por alternativas como telas de aço soldadas ou adição de fibras de aço ao concreto (taxa de 1,5\% de fibras de $25 \mathrm{~mm}$ de comprimento). Para isto, foram feitos ensaios experimentais de cinco modelos físicos de pilares mistos parcialmente revestidos solicitados por compressão centrada e de um modelo solicitado por compressão excêntrica. Os resultados demonstraram-se promissores no que tange à substituição da armadura, mesmo para a situação com excentricidade na força aplicada. Em complemento, foi desenvolvida uma simulação numérica dos modelos físicos ensaiados utilizando o pacote computacional DIANA ${ }^{\circledR}$, fundamentado no método dos elementos finitos, com o pré e pós-processador FX+. Apesar da hipótese simplificadora de aderência perfeita entre o aço e o concreto, o modelo numérico representou adequadamente o comportamento dos pilares mistos.

Palavras-chave: Pilares mistos parcialmente revestidos. Elementos mistos de aço-concreto. Análise Experimental. Análise Numérica. 

PEREIRA, M. F. (2014). Experimental and Numerical Analysis of Partially Encased Composite Columns. Thesis (Masters Degree) - Scholl of Engineering of São Carlos, University of São Paulo, São Carlos, 2014.

Partially encased composite columns are the result of the association of a steel profile and concrete filling working together. The most commonly used steel profiles have I or $\mathrm{H}$ cross sections not completely covered by concrete, with filling only in the region between flanges. In Brazil, the use of partially encased composite columns is still incipient. However, the introduction of design procedures for these columns in Brazilian Code ABNT - NBR 8800:2008 and also their inherent constructive advantages have enabled the use of these elements in buildings across the country, especially for large constructions. In this context, the main objective of this work is to analyze the structural behavior of these columns and evaluate the possibility of replacing the traditional reinforcement using steel rebar for alternatives such as welded steel meshes or steel fibers added to the concrete (rate of $1.5 \%$ and $25 \mathrm{~mm}$ long). To achieve these goals, experimental tests on five models of partially encased composite columns submitted to axial loading and one model subjected to eccentric loading were performed. The results proved to be promising in terms of replacing the traditional reinforcement, even for the situation with eccentricity of the applied force. In addition, a numerical modeling of the studied columns was developed, using finite element based software DIANA ${ }^{\circledR}$ with FX + . Despite simplifying assumptions of perfect bond between steel and concrete, the numerical model adequately represented the behavior of the columns.

Keywords: Partially encased.composite columns, steel-concrete composite columns. experimental analysis, numerical modeling. 



\section{LISTA DE SÍMBOLOS e ABREVIATURAS}

\begin{tabular}{|c|c|c|}
\hline$A_{a}$ & - & Área de aço \\
\hline$A_{c}$ & - & Área de concreto \\
\hline$A_{s}$ & - & Área da seção transversal da armadura \\
\hline$A_{\text {sn }}$ & - & Soma das áreas das barras da armadura na região de altura $2 \mathrm{~h}_{\mathrm{n}}$ \\
\hline$A_{\text {sni }}$ & - & Área de cada barra da armadura na região de altura $2 \mathrm{~h}_{\mathrm{n}}$ \\
\hline$A_{\text {lig }}$ & - & Área da superfície de fratura acima do entalhe projetada no plano \\
\hline & & ortogonal ao eixo longitudinal do corpo-de-prova \\
\hline$b_{f}$ & - & Largura da mesa \\
\hline $\mathrm{d}$ & - & Altura total da seção transversal; distância; dimensão \\
\hline $\mathrm{D}$ & - & Diâmetro \\
\hline e & - & Excentricidade \\
\hline $\mathrm{E}, \mathrm{E}_{\mathrm{a}}$ & - & Módulo de elasticidade do aço \\
\hline $\mathrm{E}_{\mathrm{c}}, \mathrm{E}_{\mathrm{cs}}$ & - & Módulo de elasticidade secante de concreto \\
\hline $\mathrm{E}_{\mathrm{c}, \mathrm{Red}}$ & - & $\begin{array}{l}\text { Módulo de elasticidade reduzido do concreto devido aos efeitos } \\
\text { de retração e fluência }\end{array}$ \\
\hline $\mathrm{E}_{\mathrm{s}}$ & - & Módulo de elasticidade do aço da armadura do concreto \\
\hline $\mathrm{e}_{\mathrm{yi}}$ & - & Distância do eixo da barra da armadura ao eixo $\mathrm{X}$ \\
\hline$e_{x i}$ & - & Distância do eixo da barra da armadura ao eixo $\mathrm{Y}$ \\
\hline $\mathrm{f}_{\mathrm{cd}}$ & - & Resistência de cálculo do concreto à compressão \\
\hline $\mathrm{f}_{\mathrm{ck}}$ & - & Resistência característica do concreto à compressão \\
\hline $\mathrm{f}_{\mathrm{cm}}$ & - & Resistência média à compressão do concreto \\
\hline $\mathrm{f}_{\mathrm{ct}}$ & - & Resistência do concreto à tração \\
\hline $\mathrm{f}_{\mathrm{y}}$ & - & Resistência ao escoamento do aço \\
\hline $\mathrm{f}_{\mathrm{yd}}$ & - & Resistência de cálculo ao escoamento do aço \\
\hline$f_{\text {ys }}$ & - & Resistência ao escoamento do aço da armadura \\
\hline $\mathrm{f}_{\mathrm{yd}}$ & - & Resistência de cálculo ao escoamento do aço da armadura \\
\hline $\mathrm{G}_{\mathrm{f}}$ & - & Energia de fraturamento do concreto (modo I) \\
\hline $\mathrm{G}_{\mathrm{c}}$ & - & Energia de fraturamento do concreto à compressão \\
\hline $\mathrm{h}$ & - & Altura de seção, largura de banda \\
\hline$h_{n}$ & - & Distância entre o centro geométrico e a linha neutra \\
\hline
\end{tabular}




\begin{tabular}{|c|c|c|}
\hline$I_{a}, I_{c}, I_{s}$ & - & $\begin{array}{l}\text { Momento de inércia do perfil de aço, concreto e barras da } \\
\text { armadura, respectivamente }\end{array}$ \\
\hline $\mathrm{k}$ & - & Parâmetro em geral \\
\hline 1 & - & Comprimento \\
\hline $\mathrm{L}_{\mathrm{x}}, \mathrm{L}_{\mathrm{y}}$ & - & Comprimento de flambagem na direção x e na direção y \\
\hline$M_{x, R d}, M_{y, R d}$ & - & Momentos fletores resistentes de cálculo com relação aos eixos x e y \\
\hline $\mathrm{M}_{\mathrm{pl}, \mathrm{x}, \mathrm{Rd}}, \mathrm{M}_{\mathrm{pl}, \mathrm{y}, \mathrm{I}}$ & $y, \mathrm{Rd}$ & $\begin{array}{l}\text { Momentos fletores resistentes de cálculo com } \\
\text { relação aos eixos x e y }\end{array}$ \\
\hline $\mathrm{M}_{\mathrm{x}, \mathrm{i}, \mathrm{Sd}}, \mathrm{M}_{\mathrm{y}, \mathrm{i}, \mathrm{Sd}}$ & & $\begin{array}{l}\text { Momentos devidos às imperfeições ao longo do pilar, em relação } \\
\text { ao eixo x e ao eixo y }\end{array}$ \\
\hline $\mathrm{M}_{\mathrm{x}, \mathrm{Sd}}$ e $\mathrm{M}_{\mathrm{y}, \mathrm{Sd}}$ & - & Momentos fletores solicitantes em relação aos eixos x e y \\
\hline $\mathrm{M}_{\mathrm{x}, \mathrm{tot}, \mathrm{Sd}}, \mathrm{M}_{\mathrm{y}, \mathrm{to}}$ & tot,Sd & $\begin{array}{l}\text { Momentos fletores solicitantes de cálculo totais em relação aos } \\
\text { eixo x e y }\end{array}$ \\
\hline $\mathrm{M}_{\mathrm{Sd}}$ & - & Momento solicitante de cálculo \\
\hline $\mathrm{N}_{\mathrm{e}}$ & - & Força crítica de Euler \\
\hline $\mathrm{N}_{\mathrm{G}, \mathrm{Sd}}$ & - & Parcela permanente e quase permanente de Nsd \\
\hline $\mathrm{N}_{\mathrm{pl}, \mathrm{a}, \mathrm{Rd}}$ & - & Força axial resistente de cálculo à plastificação total do perfil \\
\hline $\mathrm{N}_{\mathrm{pl}, \mathrm{c}, \mathrm{Rd}}$ & - & Força axial resistente de cálculo à plastificação total do concreto \\
\hline $\mathrm{N}_{\mathrm{pl}, \mathrm{s}, \mathrm{Rd}}$ & - & $\begin{array}{l}\text { Força axial resistente de cálculo à plastificação total das barras de } \\
\text { armadura }\end{array}$ \\
\hline $\mathrm{N}_{\mathrm{pl}, \mathrm{Rd}}$ & - & $\begin{array}{l}\text { Força axial resistente de cálculo da seção transversal do pilar } \\
\text { misto à plastificação total; }\end{array}$ \\
\hline $\mathrm{N}_{\mathrm{Rd}}$ & - & Força axial resistente de cálculo de tração ou compressão \\
\hline $\mathrm{N}_{\text {Sd }}$ & - & Força normal solicitante no pilar \\
\hline$t_{f}$ & - & Espessura da mesa do perfil metálico \\
\hline$t_{w}$ & - & Espessura da alma do perfil metálico \\
\hline $\mathrm{V}_{\mathrm{Sd}}$ & - & força cortante de cálculo \\
\hline$V_{f}$ & - & Volume de fibras \\
\hline $\mathrm{W}_{0}$ & - & $\begin{array}{l}\text { Área abaixo da curva força vs. deslocamento obtida pelo ensaio } \\
\text { de flexão sob três pontos }\end{array}$ \\
\hline $\mathrm{Z}_{\mathrm{a}}, \mathrm{Z}_{\mathrm{c}}, \mathrm{Z}_{\mathrm{s}}$ & - & $\begin{array}{l}\text { Módulo de resistência plástico da seção do perfil de aço, concreto } \\
\text { fissurado e armadura }\end{array}$ \\
\hline
\end{tabular}




\begin{tabular}{|c|c|c|}
\hline $\mathrm{Z}_{\mathrm{an}}, \mathrm{Z}_{\mathrm{cn}}, \mathrm{Z}_{\mathrm{sn}}$ & - & Módulo de resistência plástico \\
\hline$\alpha_{c}$ & - & Fator de contribuição do concreto na capacidade resistente \\
\hline$\beta$ & - & Coeficiente de retenção ao cisalhamento \\
\hline$\delta$ & - & $\begin{array}{l}\text { Relação entre a resistência de cálculo da seção de aço e a } \\
\text { resistência de cálculo da seção mista }\end{array}$ \\
\hline$\delta_{0}$ & - & Flecha última registrada no ensaio de flexão \\
\hline$\varepsilon_{\mathrm{c}}$ & - & Deformação do concreto \\
\hline$\varepsilon_{\mathrm{c} 1}$ & - & Deformação de pico de acordo com a resistência do concreto \\
\hline$\lambda_{0, \mathrm{~m}}$ & - & Índice de esbeltez reduzido \\
\hline$\sigma$ & - & Tensão normal \\
\hline$\tau$ & - & Tensão de cisalhamento \\
\hline$\varphi$ & - & Coeficiente de fluência do concreto \\
\hline$\chi$ & - & Fator de redução de acordo com o índice de esbeltez reduzido \\
\hline ABNT & - & Associação Brasileira de Normas Técnicas \\
\hline ASTM & - & American Society for Testing and Materials \\
\hline CEB & - & Comité Euro-International du Beton \\
\hline $\mathrm{CP}$ & - & Corpo de prova \\
\hline EESC & - & Escola de Engenharia de São Carlos da Universidade de São Paulo \\
\hline FAPESP & - & Fundação de Aparo à Pesquisa do Estado de São Paulo \\
\hline LE-EESC & - & Laboratório de Estruturas do Departamento de Engenharia de Estruturas \\
\hline PMPR & - & Pilar misto parcialmente revestido \\
\hline $\mathrm{ZIC}$ & - & Zona de introdução de carga \\
\hline
\end{tabular}





\section{SUMÁRIO}

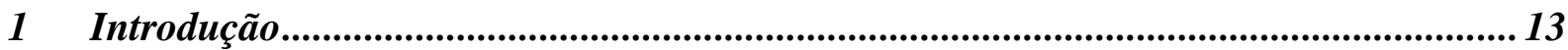

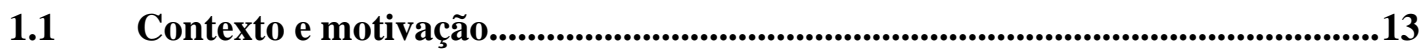

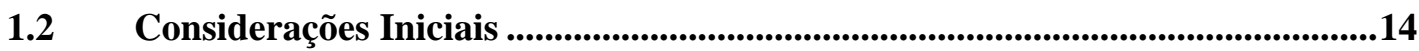

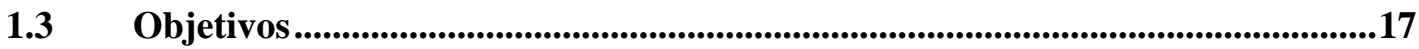

1.4 Metodologia .............................................................................................................18

1.5 Organização da dissertação ..............................................................................................18

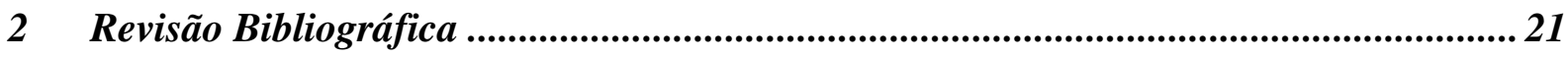

2.1 Considerações iniciais...................................................................................................21

2.2 Componentes da Seção Mista ......................................................................21

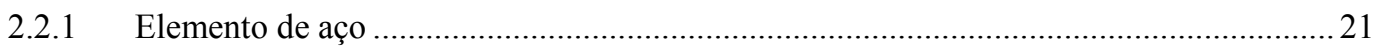

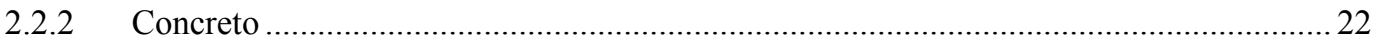

2.3 Concreto com adição de fibras de aço.............................................................23

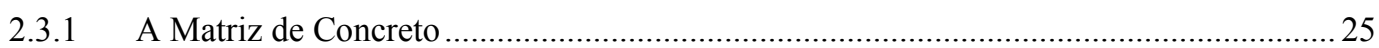

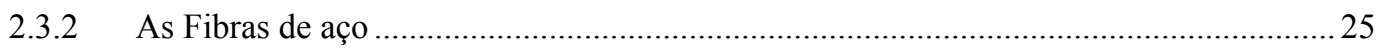

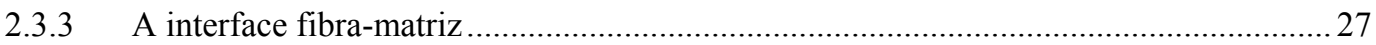

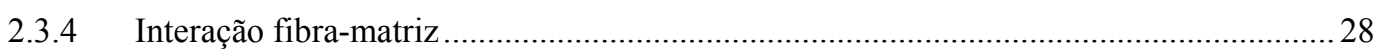

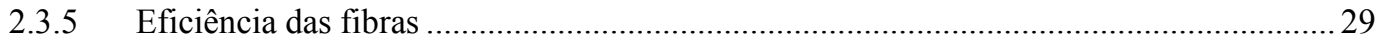

2.3.6 Comportamento do concreto com adição de fibras ........................................................... 31

2.4 Pesquisas a respeito de Pilares mistos parcialmente revestidos (PMPR) ..........33

2.4.1 PMPR com seções padronizadas ............................................................................... 33

2.4.2 PMPR fabricado com seções soldadas de chapa fina ..................................................... 36

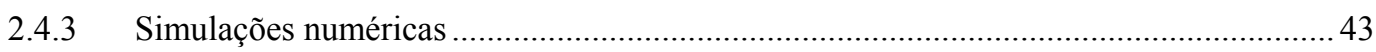

2.5 Ligações entre o pilar misto e demais elementos estruturais .................................45

2.6 Panorama Nacional ..........................................................................................................48

2.7 Considerações Finais ........................................................................................................51

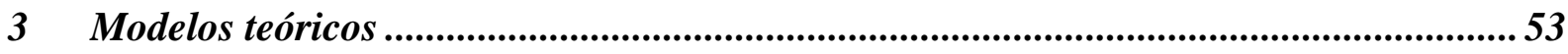

3.1 Considerações iniciais.................................................................................................53

3.2 Norma brasileira: ABNT - NBR 8800:2008 .................................................53

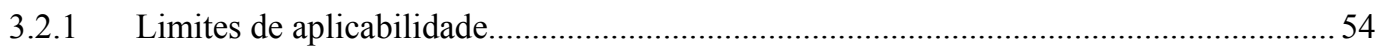

3.2.2 Flambagem local dos elementos de aço …………………………………………….... 56

3.2.3 Cisalhamento nas superfícies de contato aço e concreto .................................................. 56

3.2.4 Dimensionamento de pilares mistos parcialmente revestidos segundo a ABNT - NBR 8800:2008 57

3.2.5 Comentário sobre as normas de dimensionamento de pilares mistos..... 
3.3 Estimativa das propriedades mecânicas do concreto.............................................. 65

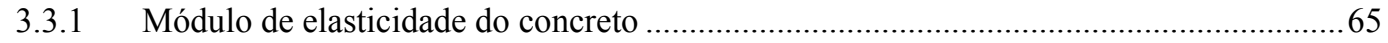

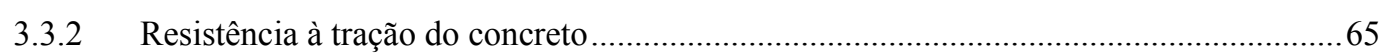

3.3.3 Energia de fraturamento do concreto........................................................................65

Considerações finais.................................................................................. 67

$4 \quad$ Investigação experimental .....................................................................................................69

4.1 Considerações iniciais .............................................................................................69

4.2 Características gerais dos modelos físicos.................................................................. 69

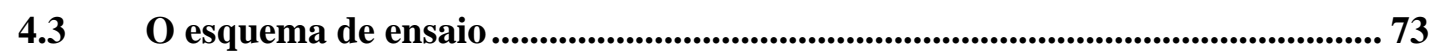

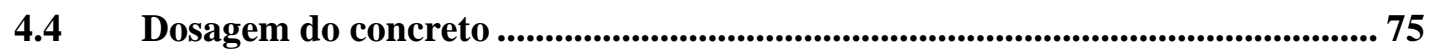

4.5 Instrumentação dos modelos dos pilares parcialmente revestidos .................... 76

4.5.1 Registros de deformações .................................................................................... 76

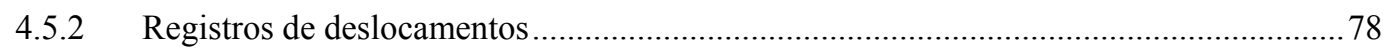

4.6 Moldagem, adensamento e cura do concreto.......................................................... 79

4.7 Caracterização dos materiais .......................................................................... 81

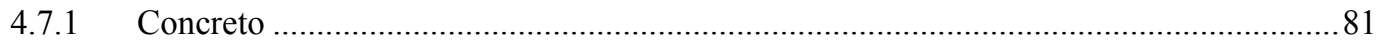

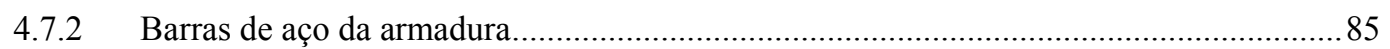

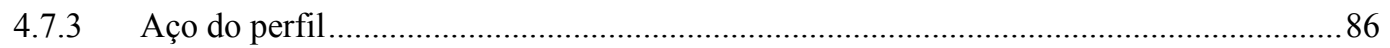

4.8 Pilares parcialmente revestidos: resultados e discussão ........................................ 87

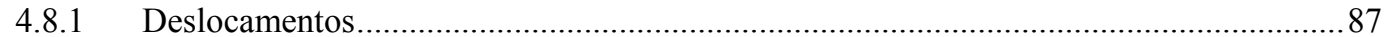

4.8.2 Deformação na mesa do perfil metálico ..................................................................... 95

4.8.3 Deformações na alma do perfil metálico ..................................................................98

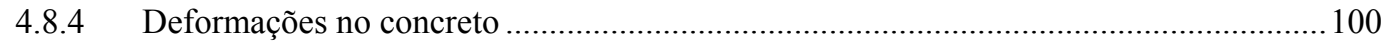

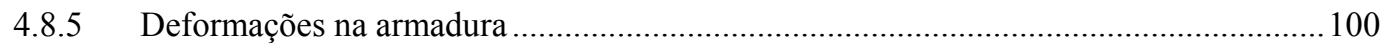

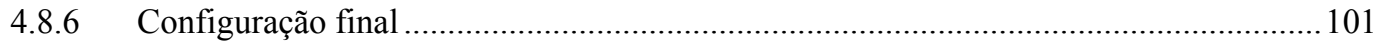

4.9 Comparação entre os resultados experimentais e normativos........................... 106

4.10 Considerações finais.............................................................................................. 107

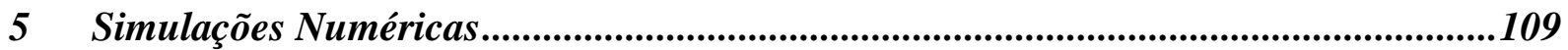

5.1 Considerações iniciais .......................................................................................... 109

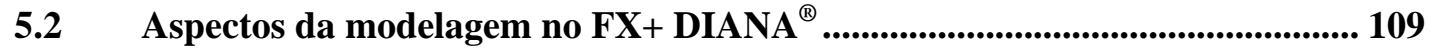

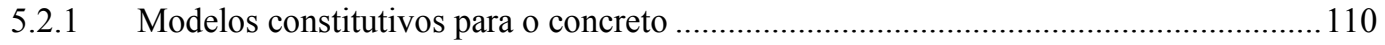

5.3 Determinação indireta da energia de fraturamento em prismas de concreto com fibras 111

5.3.1 Hipóteses adotadas na análise inversa do ensaio de tenacidade ................................... 112

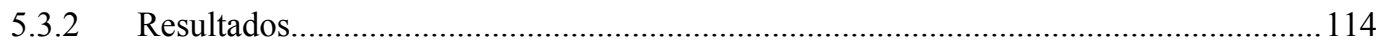

5.4 Simulações numéricas de pilares mistos parcialmente revestidos .................... 115

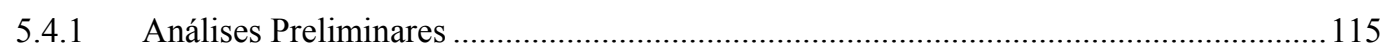




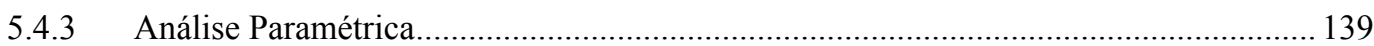

5.4.4 Avaliação qualitativa da influência da consideração da interface aço-concreto............ 143

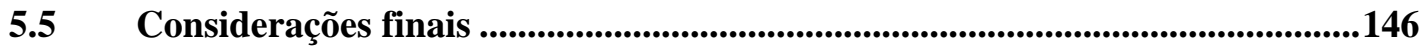

$6 \quad$ Conclusões e sugestões para novas pesquisas.................................................................. 149

6.1 Sugestão para pesquisas futuras.......................................................................152

Referências bibliográficas ................................................................................................................. 153

Apêndice A ...................................................................................................................................... 157 



\section{Introdução}

\subsection{Contexto e motivação}

Ao longo da história, as concepções estruturais se adaptaram aos materiais e técnicas disponíveis no período. Entre as diferentes combinações de materiais possíveis, a mais popular é a associação entre o aço e concreto devido a aspectos econômicos e a disponibilidade dos materiais. Essa associação é realizada tradicionalmente no concreto armado, onde barras de aço são envolvidas por concreto estrutural. A associação entre o aço e o concreto, em termos do que hoje conhecemos como estruturas mistas, remonta ao início do século XX.

O elemento misto de aço e concreto é a associação de perfis estruturais de aço com concreto estrutural simples ou armado, de maneira a formarem uma seção resistente composta. Neste sistema, a união do aço com o concreto visa agrupar as vantagens de cada um dos referidos materiais em um só elemento.

Graças à rigidez e à resistência do concreto, o comportamento à compressão dos perfis frente aos problemas de instabilidades locais ou globais é melhorado, ao passo que na região de concreto comprimido, o seu comportamento passa a ser mais dúctil, quando da comparação com os elementos estruturais não compostos (perfil de aço isolado ou pilar de concreto armado)

Pode-se descrever ainda como vantagens dos sistemas mistos de aço e concreto a redução das dimensões dos elementos, com consequente economia de materiais, mão-de-obra e maior área livre por pavimento, além de grande resistência, rigidez e ductilidade.

Destaca-se entre os elementos mistos o pilar misto parcialmente revestido que é objeto de estudo deste trabalho. Neste capítulo é feita uma breve descrição das suas principais características, destacando aspectos construtivos e estruturais.

Este capítulo tem por finalidade ressaltar a importância de estudos como este, apresentando as justificativas e os objetivos do trabalho. Além disso, descrever a metodologia empregada para o seu desenvolvimento. Por fim apresenta-se a organização dos capítulos da dissertação com uma breve descrição do conteúdo presente em cada um deles. 


\subsection{Considerações Iniciais}

Pilares mistos de aço e concreto são elementos estruturais sujeitos predominantemente a esforços de compressão, cuja seção transversal é formada por um perfil metálico e concreto trabalhando solidariamente. De acordo com a disposição do concreto na seção mista, os pilares mistos podem ser classificados como preenchidos, revestidos ou parcialmente revestidos (Figura 1.1).

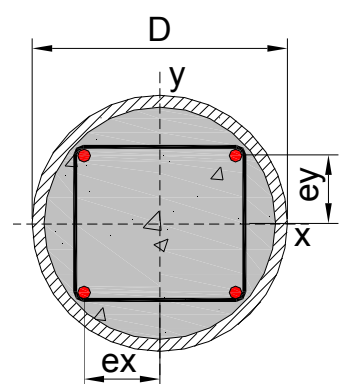

a) Preenchidos

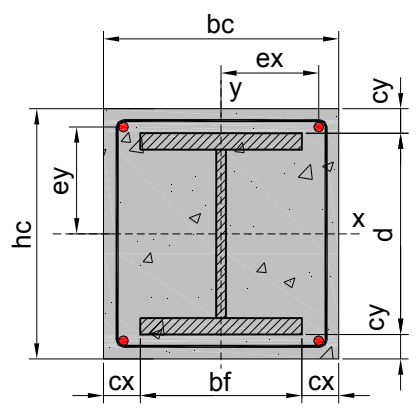

b) Revestidos

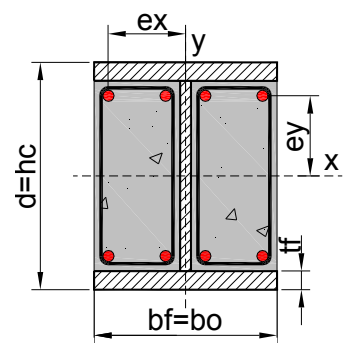

c) Parcialmente revestidos

Figura 1.1- Exemplos de Pilares Mistos de Aço e concreto

Os pilares mistos preenchidos são formados por perfis tubulares (circulares ou retangulares) preenchidos com concreto estrutural (Figura 1.1 - (a)). Neste caso, o perfil metálico funciona como forma permanente, minimizando os custos. Nestes pilares a capacidade resistente é incrementada pelo confinamento do concreto exercido pelo perfil de aço, além disso, o concreto ajuda a evitar a flambagem local do perfil tubular. Segundo De Nardin (1999) este tipo de pilar apresenta excelente comportamento frente às ações de sismo devido à alta resistência, rigidez e ductilidade além de menores dimensões e massa.

Já os pilares mistos revestidos (Figura 1.1 - (b)) caracterizam-se pelo completo envolvimento do perfil metálico pelo concreto, este tipo de pilar, ainda pode ser composto por um ou mais perfis de aço na mesma seção. Este tipo de pilar exige a utilização de formas para concretagem e armaduras (longitudinal e transversal) a fim de evitar fissuras no concreto, isto é, um processo construtivo similar ao realizado em pilares de concreto armado.

Finalmente há o pilar misto parcialmente revestido, objeto de estudo deste trabalho, que é formado pelo perfil metálico, normalmente com seções "I" ou "H", tendo a região entre as mesas preenchida por concreto (Figura 1.1 - (c)). Nestes pilares é obrigatório o uso de armadura longitudinal e transversal, similar ao pilar revestido, especialmente para prevenir 
fissuras e fendilhamento do concreto, impedir o seu descolamento do perfil e contribuir em situações de incêndio (ABNT - NBR 8800: 2008). Além disso, as porções da mesa que ficam expostas podem requerer algum tipo de proteção contra incêndio, como por exemplo, a pintura.

É pertinente salientar que o emprego de elementos mistos constitui não só uma opção de sistema estrutural, mas também de um processo construtivo, portanto, desde que sejam adotadas técnicas construtivas adequadas ao sistema, pode-se dizer que as estruturas mistas apresentam também vantagens em termos do processo construtivo. Por exemplo, comparando as estruturas mistas com as estruturas em concreto armado, verifica-se a possibilidade de reduzir ou dispensar formas e escoramentos, diminuir custos provenientes de materiais e mãode-obra, reduzir o peso próprio da estrutura - utilização de elementos mistos estruturalmente mais eficientes - e aumentar a precisão dimensional dos elementos.

As estruturas mistas de aço e concreto respondem satisfatoriamente aos requisitos racionalização da construção, pois tanto os elementos de aço quanto os de concreto podem ser pré-fabricados industrialmente, ficando apenas as etapas de içamento e montagem para serem realizadas in-loco.

Um bom exemplo de aplicação de estruturas mistas é o Hotel Ibis Canoas, construído em Canoas (RS), no qual foi utilizado um sistema construtivo industrializado que garantiu agilidade à obra, construída em apenas 67 dias. No referido empreendimento foi adotado um sistema misto em aço e concreto a fim de aproveitar as características positivas de cada um destes materiais e contribuir para uma obra mais limpa e precisa. A estrutura mista foi composta por pilares de aço parcialmente revestidos, lajes com forma de aço incorporada e vigas metálicas trabalhando em conjunto com as lajes. Já as fachadas e vedações foram executadas com o sistema steel framing, no qual os perfis leves de aço foram revestidos por placas à base de argamassa de cimento e gesso (ARQUITETURA \& AÇO, 2013).

Ainda em relação à obra do Hotel Ibis Canoas, foram ponderados aspectos estruturais e econômicos para a escolha da solução a ser adotada para os pilares da obra. Para tanto foram avaliadas as seguintes soluções para os pilares: pilar de aço isolado, parcialmente revestido, revestido e preenchido de concreto. A utilização do pilar de aço isolado foi descartada devido à necessidade de proteção passiva, por exemplo, a pintura intumescente, que apresenta elevado custo. Já o pilar revestido tornou-se inviável por necessitar o uso de formas que elevam os custo e tempo de execução da obra. Finalmente, ainda que o pilar misto preenchido apresentasse a melhor resposta estrutural, o preço elevado dos perfis tubulares e as limitações 
de suas dimensões comerciais inviabilizaram a sua utilização (informação pessoal) ${ }^{1}$. Desta forma, o pilar misto parcialmente revestido mostrou-se o mais competitivo no que tange a aspectos econômicos e estruturais.

Os pilares mistos parcialmente revestidos utilizados na obra do Hotel Ibis Canoas (RS) eram compostos por perfis do tipo "I" e a região entre as mesas foi preenchida por concreto. Para garantir o comportamento conjunto do aço e do concreto utilizou-se armadura de vergalhões e conectores de cisalhamento como indicado na Figura 1.2.
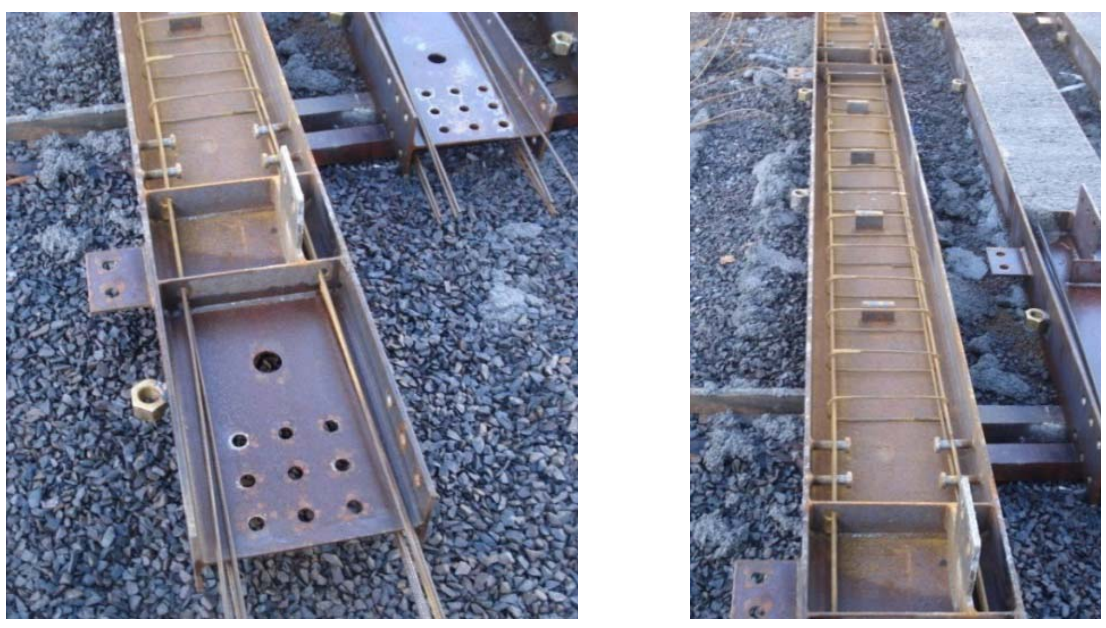

Figura 1.2 - Perfil metálico, armadura e conectores de cisalhamento (informação pessoal) ${ }^{1}$

Além disso, para contribuir para a agilidade do processo construtivo e economizar no custo total da obra, a concretagem do pilar foi executada no canteiro de obras com os pilares posicionados na posição horizontal, eliminando a necessidade de utilização de formas (Figura $1.3)$.

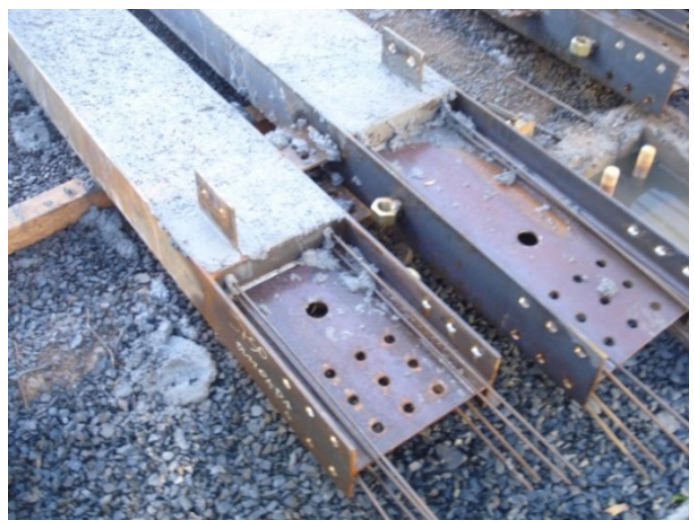

Figura 1.3 - Concretagem dos pilares mistos na posição horizontal (informação pessoal) ${ }^{1}$

\footnotetext{
${ }^{1}$ Gilsimar, S. N. Hotel Ibis Canoas. Mensagem recebida por: gilsimar.nogueira@medabrilcom.br em 4
} ago. 2013 . 
Vale salientar que o pilar misto parcialmente revestido apresenta dificuldades na execução das ligações, e em muitos casos é necessária a interrupção da concretagem na região da ligação; maiores detalhes podem ser vistos no item 2.5 do Capítulo 2.

Outra dificuldade no processo executivo dos pilares mistos parcialmente revestidos está na obrigatoriedade de utilização de armaduras longitudinal e transversal para garantir a integridade do concreto. Segundo a ABNT-NBR 8800:2008, as armaduras transversais devem ser ancoradas no perfil de aço através de furos na alma ou conectores de cisalhamento com espaçamento não superior a $500 \mathrm{~mm}$ ou ainda ser soldadas à alma, o que dificulta ainda mais o processo executivo. Desta forma, verifica-se a necessidade de estudos específicos abordando esta questão, dada a sua importância para o comportamento dos pilares mistos especialmente no tocante a integridade do concreto.

Neste sentido, objetivando a melhoria do processo construtivo, propõe-se o desenvolvimento de análises experimentais e numéricas a fim de se discutir a viabilidade de substituição das armaduras transversais nos pilares parcialmente revestidos, desde que sejam mantidas as características de ductilidade do pilar e a integridade do concreto.

\subsection{Objetivos}

Este trabalho tem por objetivo geral estudar o comportamento estrutural de pilares constituídos de perfil de aço parcialmente revestido de concreto, especialmente a resistência da seção transversal e a integridade do concreto.

Para atingir o objetivo geral do presente estudo foram traçadas as seguintes metas:

- Investigar experimentalmente a capacidade resistente da seção mista em modelos experimentais de pilares mistos parcialmente revestidos;

- Validar modelos numéricos desenvolvidos com o pacote computacional Fx+ for DIANA ${ }^{\circledR}$ v. 9.4.4, que permitam extrapolar os resultados experimentais;

- Realizar uma análise paramétrica;

- Avaliar a possibilidade de substituição da armadura de pilares mistos parcialmente revestidos por telas de aço soldadas entre as mesas do perfil metálico ou pela utilização de concreto com adição de fibras metálicas. 


\subsection{Metodologia}

A metodologia proposta no presente trabalho pode ser dividida em cinco grandes etapas: revisão bibliográfica, investigação experimental, simulação numérica e análise e discussão dos resultados. Cada etapa é descrita resumidamente abaixo:

i. Revisão bibliográfica realizada com o objetivo de compreender o comportamento estrutural de elementos mistos de aço e concreto, isto é, compreender fenômenos relacionados à aderência, à transferência de forças na interface aço-concreto e aos possíveis modos de falhas. Além disso, devem-se coletar e avaliar resultados de estudos já realizados neste sentido, sobretudo com pilares mistos parcialmente revestidos;

ii. Investigação experimental visando obter dados sobre o comportamento de pilares mistos parcialmente revestidos com ou sem a utilização de armaduras transversais;

iii. Simulação numérica realizada com o pacote computacional $\mathrm{Fx}+$ for DIANA ${ }^{\circledR}$ v. 9.4.4, a fim de simular numericamente o comportamento e a capacidade resistente dos pilares mistos parcialmente revestidos. Foi realizada ainda uma análise paramétrica para avaliação de parâmetros relevantes que não puderam ser investigados experimentalmente;

iv. Análise e discussão dos resultados no qual serão confrontados os resultados experimentais e os obtidos com a simulação numérica. Com base nas análises e estudos comparativos desenvolvidos neste item, serão elaboradas as conclusões possíveis e pertinentes ao assunto em questão. Espera-se ainda que a análise numérica dos protótipos possibilite extrapolar os resultados experimentais;

v. Considerações finais comparando as análises e desempenho estrutural dos pilares avaliados.

\subsection{Organização da dissertação}

O corpo da dissertação foi organizado em seis capítulos. Neste primeiro capítulo são apresentadas as características dos pilares mistos parcialmente revestidos. Além disso, apresentam-se as justificativas, objetivos e metodologia da pesquisa. 
O Capítulo 2 é denominado "Revisão Bibliográfica" e foi elaborado a partir da coleta de estudos já realizados, sobretudo sobre o comportamento dos pilares mistos parcialmente revestidos. Além disso, é abordado o comportamento do concreto com fibras de aço.

O Capítulo 3 aborda modelos teóricos para dimensionamento e verificação de pilares mistos parcialmente revestidos presentes em algumas normas técnicas. Em seguida, são descritos procedimentos para estimar as propriedades mecânicas do concreto simples e com fibras.

O Capitulo 4 apresenta a metodologia adotada no programa experimental e os resultados obtidos.

O Capítulo 5 apresenta os procedimentos adotados para a simulação numérica dos pilares mistos e uma análise paramétrica. São feitas comparações e conclusões sobre o comportamento dos pilares mistos avaliados.

Finalmente o Capítulo 6 traz as conclusões do trabalho, de acordo com a análise comparativa dos resultados decorrentes das simulações numéricas e investigação experimental, e sugestões para novas pesquisas nesta área. 
20 Introdução 


\section{Revisão Bibliográfica}

\subsection{Considerações iniciais}

Neste capítulo são apresentados os fundamentos teóricos sobre os elementos que constituem os pilares mistos parcialmente revestidos (aço do perfil, armadura e concreto) em especial os conceitos relacionados ao concreto com adição de fibras.

Além disso, são descritos os diversos trabalhos relacionados a pilares mistos parcialmente revestidos (PMPR) encontrados na literatura técnica. Os trabalhos técnicos foram organizados em dois grupos: os PMPR fabricados com seções soldadas de chapas finas e os PMPR fabricações com seções padronizadas, a fim de possibilitar uma visão geral dos parâmetros mais estudados e de como estes interferem no comportamento de cada um dos grupos.

Finalmente, apontam-se alguns aspectos e hipóteses relativos a simulações numéricas de PMPR permitindo nortear as simulações desenvolvidas neste trabalho.

\subsection{Componentes da Seção Mista}

Nos elementos mistos, o aço e o concreto são associados de forma que a seção mista incorpore as qualidades de cada um dos materiais. Desta forma, o comportamento estrutural da seção mista depende das propriedades mecânicas de aço e concreto, as quais podem ser avaliadas por ensaios de caracterização ou estimadas por meio de modelos teóricos.

\subsubsection{Elemento de aço}

Nos pilares mistos o aço é utilizado nos perfis metálicos, nas barras da armadura e nos conectores de cisalhamento. As principais características mecânicas associadas ao aço são a alta resistência e a ductilidade, isto é, este apresenta grandes deformações antes da ruptura. A ductilidade é indispensável, pois permite que sofram deformação plástica sem que ocorra ruptura. Salienta-se que o aço pode ter suas propriedades alteradas de acordo com a conformação mecânica ou tratamento térmico.

Por meio de ensaios de tração podem-se obter os diagramas tensão vs. deformação do aço. Ao se observarem esses diagramas, verifica-se que o comportamento linear, definido pelo módulo de elasticidade, se limita a uma faixa muito estreita de deformações. Ao entrar no 
regime de escoamento o material pode apresentar basicamente dois tipos de comportamento: com ou sem patamar de escoamento. Após isso, se observa no diagrama um trecho de encruamento onde há um aumento da resistência. Os aços dos perfis estruturais normalmente apresentam patamar de escoamento definido. Já os aços da armadura apresentam diagramas sem patamar de escoamento. São aços que passaram por tratamentos a frio ou térmicos durante a fabricação (Figura 2.1(b)).

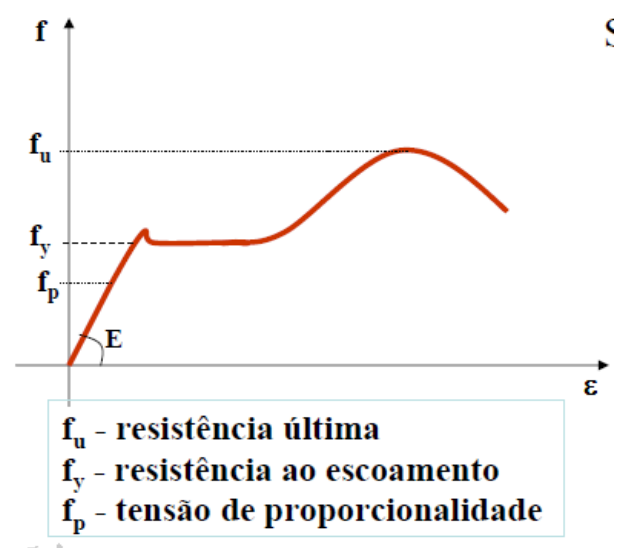

a)

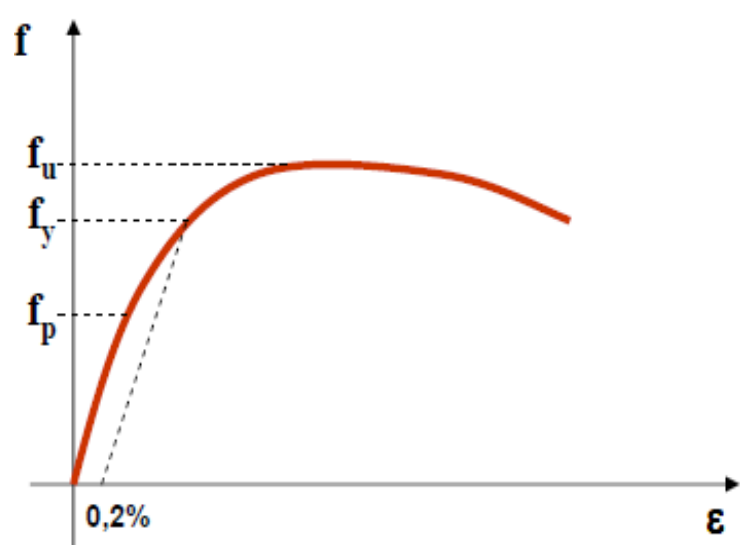

b)

Figura 2.1 - Diagrama de tensão x deformação a) com patamar definido b) sem patamar definido

\subsubsection{Concreto}

O concreto é um dos materiais mais difundidos na construção civil devido às suas características de resistência e durabilidade, além de possibilitar a execução de peças com as mais variadas formas, dando liberdade aos projetos arquitetônicos. No caso específico de elementos mistos, o concreto é utilizado para revestir ou preencher os perfis metálicos e promover a rigidez da estrutura.

Trata-se de um compósito constituído por um meio aglomerante (matriz de cimento) e partículas de agregados. As propriedades mecânicas do concreto são influenciadas pela microestrutura do mesmo, isto é, pelo tamanho, forma e distribuição das fases presentes, que são complexas e heterogêneas (METHA e MONTEIRO, 2008).

Desta forma, a caracterização mecânica do concreto depende das características e proporções de cada material constituinte. Para obter estas propriedades podem-se utilizar modelos teóricos ou realizar ensaios de caracterização.

Tradicionalmente, a resistência à compressão do concreto é a propriedade mais valorizada no cálculo estrutural ou no controle de qualidade, apesar de outras características, 
como permeabilidade e durabilidade, serem também relevantes para o comportamento do concreto. Isto ocorre porque os ensaios para obter valores de resistência à compressão são mais simples de serem executados do que os ensaios para obter outras propriedades, como o módulo de elasticidade, e também porque grande parte das propriedades mecânicas do concreto pode ser relacionada à resistência a compressão. Geralmente em projetos estruturais de concreto armado, para o cálculo da capacidade resistente do elemento considera-se que o concreto resiste apenas a tensões de compressão, entretanto as tensões de tração devem ser levadas em consideração, pois estão associadas à fissuração a qual altera propriedades importantes como permeabilidade e durabilidade.

O concreto apresenta um comportamento tensão vs. deformação não linear devido às características de sua microestrutura complexa onde matriz e zona de transição na interface apresentam uma distribuição heterogênea da face sólida, poros e microfissuração. Apesar disto, é importante estimar o módulo de elasticidade para determinar as tensões induzidas pelas deformações associadas a efeitos do meio ambiente, além de ser um parâmetro relevante no projeto estrutural.

Além disso, os pilares mistos parcialmente revestidos convencionalmente possuem armaduras longitudinais e transversais. Devido à presença do perfil metálico e armaduras há um certo confinamento no concreto, como indicado na Figura 2.2.

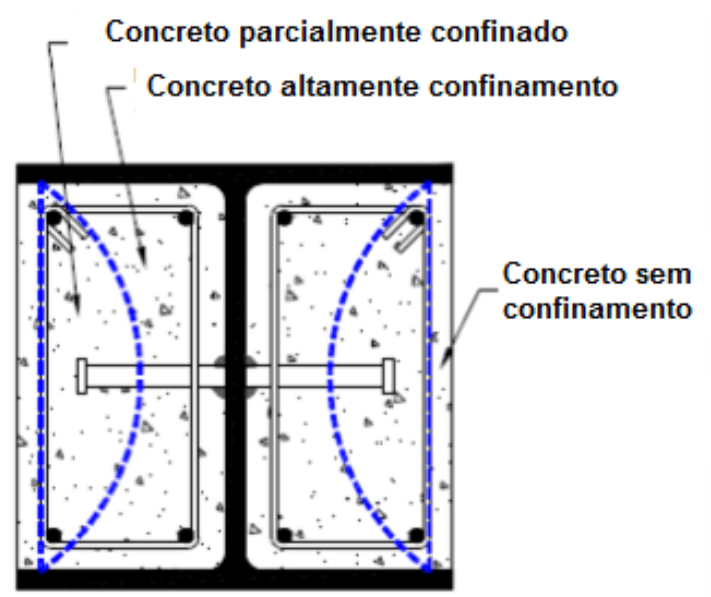

Figura 2.2 - Componentes em uma seção genérica do pilar parcialmente revestido (GAIGA, 2008)

\subsection{Concreto com adição de fibras de aço}

A fim de aprimorar as propriedades do concreto que não são adequadas para utilização estrutural e melhorar o comportamento em estado fresco, há várias pesquisas para o 
desenvolvimento de concretos especiais, dentre os quais se destaca o concreto com adição de fibras. O concreto com adição de fibras é um material compósito constituído pela matriz de concreto de cimento Portland e por fibras descontínuas e distribuídas aleatoriamente.

Para fins de reforço do concreto, podem ser utilizadas fibras sintéticas (polipropileno e nylon) e fibras de aço. As fibras sintéticas são classificadas como fibras de baixo módulo, pois possuem o módulo de elasticidade inferior ao do concreto endurecido. Sua aplicação destinase, basicamente, ao controle da fissuração do concreto nas primeiras idades. Já as fibras de aço podem ser classificadas como fibras de alto módulo. Estas não se destinam somente ao controle da fissuração, pois alteram também outras propriedades do concreto, tanto no estado fresco quanto endurecido.

A adição de fibras de aço aos concretos minimiza o comportamento frágil característico do concreto. Como consequência desta adição, o concreto apresenta uma resistência residual aos esforços aplicados, mesmo após sua fissuração. As fibras também agem durante o endurecimento do concreto inibindo o desenvolvimento de microfissuras prematuras. As características das fibras, da matriz e a interação entre elas influenciam o comportamento final do compósito.

As principais características mecânicas incrementadas pela introdução de fibras de aço no concreto são a tenacidade à flexão, a fadiga, o impacto, ductilidade e controle de fissuração. Lima Júnior (2003) destaca que a adição de fibras de aço também aprimora propriedades mecânicas do concreto como a ductilidade, e a capacidade de controle do processo de fissuração e perda de massa.

Essas características proporcionadas ao concreto pela incorporação de fibras impulsionaram um aumento significativo do uso do concreto com adição de fibras em todo mundo. Pesquisas recentes abordam desde aspectos básicos sobre a composição e comportamento mecânico do concreto com adição de fibras até a viabilidade de aplicação deste material em situações onde a armadura contínua não é essencial, utilizada com o objetivo de melhorar a ductilidade e garantir a integridade do concreto.

No Brasil, dentre os diversos tipos de fibras possíveis de utilização no concreto, a utilização das fibras de aço deu-se mais recentemente, a partir do momento em que se passou a dispor de fibras de aço produzidas especialmente para reforço do concreto (FIGUEIREDO, 1997). 


\subsubsection{A Matriz de Concreto}

A microestrutura do concreto apresenta uma zona de transição na interface entre o agregado graúdo e a pasta de cimento, normalmente mais fraca do que os outros dois constituintes e que, portanto, limita a resistência do concreto (METHA; MONTEIRO, 2008). A zona de transição é a região mais suscetível à microfissuração, podendo apresentar microfissuras mesmo antes do carregamento, causadas por movimentações diferenciais entre agregado e pasta de cimento. Essas descontinuidades dificultam o processo de transferência de tensões, prejudicando especialmente a resistência à tração do concreto.

Na produção do concreto com adição de fibras não há restrições para o tipo de cimento utilizado. Salienta-se a necessidade de garantir a trabalhabilidade com a utilização de concretos cujo abatimento seja relativamente maior antes da adição da fibra de aço. A adição de fibras compromete a trabalhabilidade do concreto devido à sua elevada área superficial que aumenta o atrito e restringe a mobilidade da mistura (LIMA JÚNIOR, 2003).

Especial atenção deve ser dada à escolha dos agregados. Segundo Nunes (2006), o uso de agregados com dimensão máxima característica maior que o comprimento das fibras prejudica o desempenho pós-fissuração do compósito. O agregado, por ser maior que a fibra, intercepta a fissura, que se propaga mais facilmente ao longo da interface agregado-matriz que ao longo ou através da fibra (Figura 2.3). Desta forma, para a escolha da dimensão do agregado, deve-se considerar a probabilidade da fissura ser interceptada pela fibra, de modo que haja uma compatibilidade dimensional entre a fibra e o agregado.

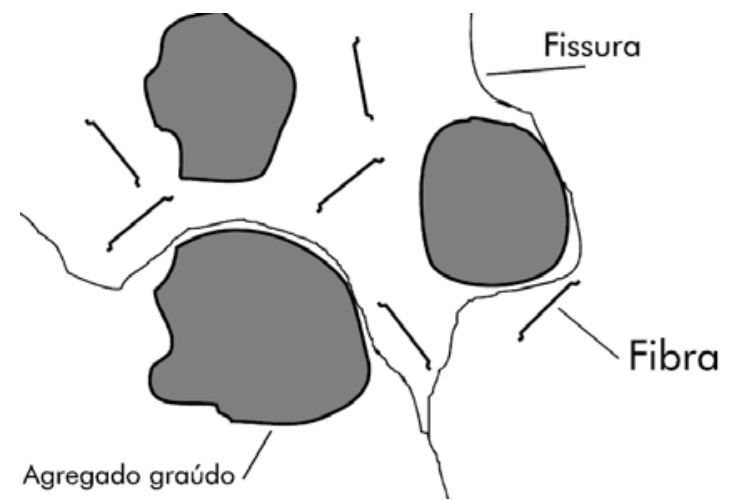

Figura 2.3 - Propagação preferencial da fissura na interface agregado-matriz (NUNES, 1998)

\subsubsection{As Fibras de aço}

As fibras adicionadas ao concreto possuem comprimentos que normalmente variam entre $25 \mathrm{~mm}$ e $63,5 \mathrm{~mm}$. Dependendo do processo de fabricação, as fibras possuem seções 
transversais variadas. As fibras podem ser fornecidas soltas ou coladas em pentes, neste último caso, verifica-se uma melhora na trabalhabilidade do concreto reforçado com fibras de aço devido a menor área superficial.

A ABNT - NBR 15530:2007 traz especificações para as fibras de aço aplicáveis ao concreto. Esta norma estabelece os parâmetros de classificação para as fibras de aço de baixo teor de carbono e os requisitos mínimos de forma geométrica, tolerâncias dimensionais, defeitos de fabricação e resistência à tração e ao dobramento. A Tabela 2.1 apresenta os tipos e classes de fibras de aço.

A ABNT - NBR 15530:2007 prevê três tipos básicos de fibras que são função de sua conformação geométrica:

- Tipo A: fibra de aço com ancoragens nas extremidades;

- Tipo C: fibra de aço corrugada e;

- Tipo R: fibra de aço reta.

Além disso, de acordo com o aço que deu origem às mesmas, as fíbras de aço são classificadas em três classes:

- Classe I: fibra oriunda de arame trefilado a frio;

- Classe II: fibra oriunda de chapa laminada cortada a frio e;

- Classe III: fibra oriunda de arame trefilado e escarificado.

Tabela 2.1- Classificação das fibras de aço (FIGUEIREDO; NETO; FARIA, 2008)

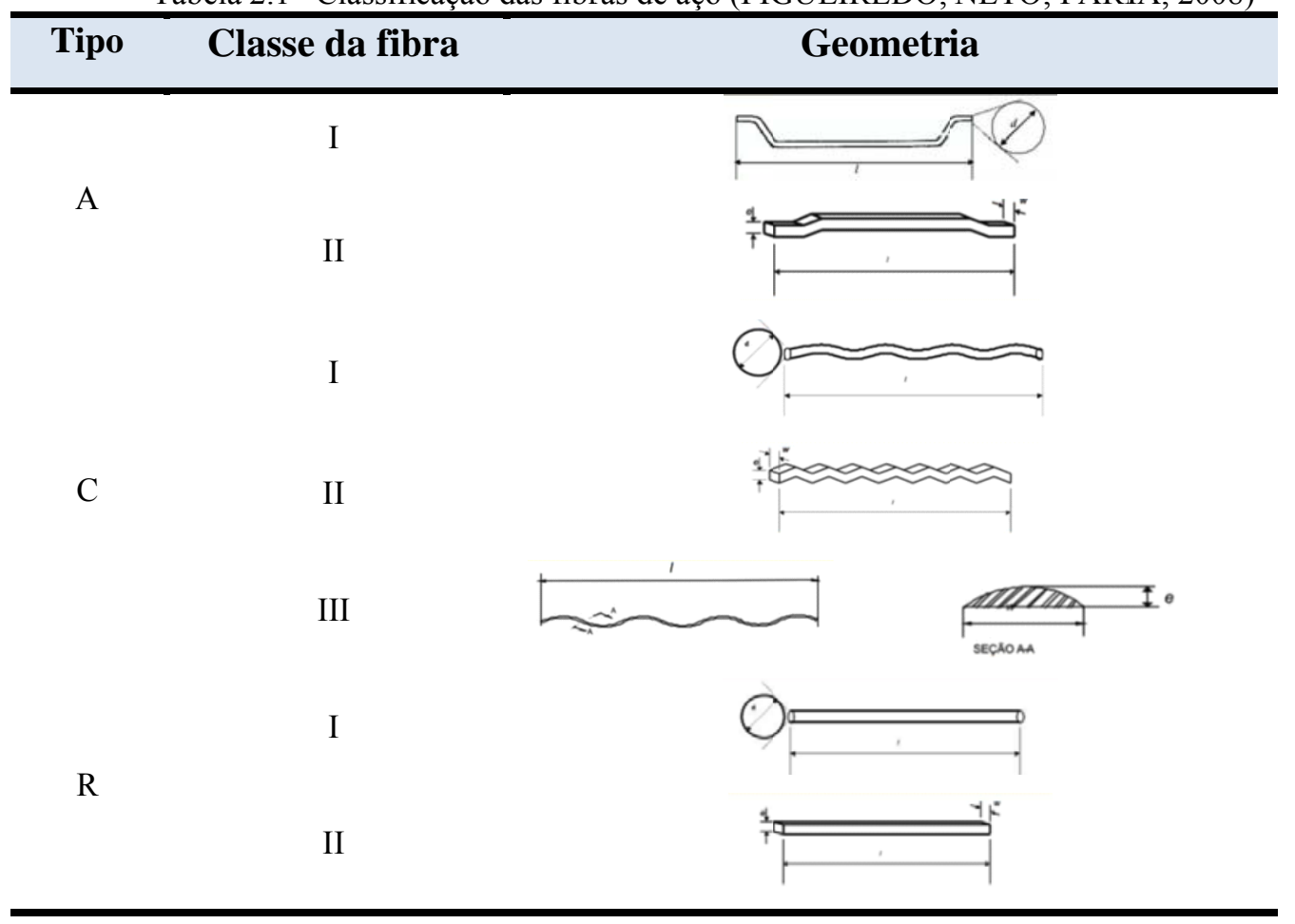


A partir da classificação proposta pela norma ABNT - NBR 15530:2007 pode-se determinar o tipo de aço utilizado na fabricação, a seção transversal e a geometria das fibras. Desta forma, é possível determinar propriedades relevantes da fibra de aço tais como o módulo de elasticidade e a resistência mecânica.

Segundo Nunes (1998), a geometria das fibras é um dos principais aspectos que interferem no desempenho do material no concreto reforçado com fibras. As deformações nas fibras (ancoragens em gancho, cones ou ondulações nas fibras) ajudam a melhorar o desempenho da fibra quanto à aderência e ao escorregamento, por meio da ancoragem mecânica.

O principal fator relacionado à geometria e que pode ser utilizado para descrever a fibra é o fator de forma ou razão de aspecto. O fator de forma pode ser definido como o comprimento da fibra dividido por seu diâmetro equivalente. O diâmetro equivalente é definido como aquele correspondente a uma circunferência de mesma área que a seção transversal da fibra.

A importância em definir este fator, segundo Figueiredo (1997), é que quanto maior o fator de forma, maior a tenacidade conferida para o concreto reforçado com fibras. Além disso, segundo Lima Júnior (2003), o fator de forma elevado prejudica a trabalhabilidade e pode contribuir para o embolamento das fibras.

Outro aspecto importante da fibra é a resistência à tração ou ao cisalhamento. Sua capacidade de reforço pós-fissuração é influenciada pela combinação de resistência e módulo de elasticidade. Se apesar do alto módulo de elasticidade, característico das fibras de aço, a resistência for baixa, as fibras apresentarão um comportamento frágil com pouca capacidade de deformação elástica e, portanto, não terão capacidade de reforçar a matriz de concreto após a fissuração.

\subsubsection{A interface fibra-matriz}

A microestrutura da matriz pasta de cimento nas proximidades das fibras, zona de transição na interface matriz-fibra, apresenta características diferentes daquelas observadas na região distante da fibra (Figura 2.4).

As características da zona de transição na interface matriz-fibra dependem do tipo de fibra e do processo de produção do concreto e são fundamentais para a definição do comportamento mecânico do compósito e a aderência entre a fibra e a matriz. 
A zona de transição na interface matriz-fibra é mais porosa e apresenta muitos cristais de $\mathrm{CH}$ (hidróxido de cálcio) e, portanto, é mais fraca e permite a propagação preferencial das fissuras ao longo da interface.

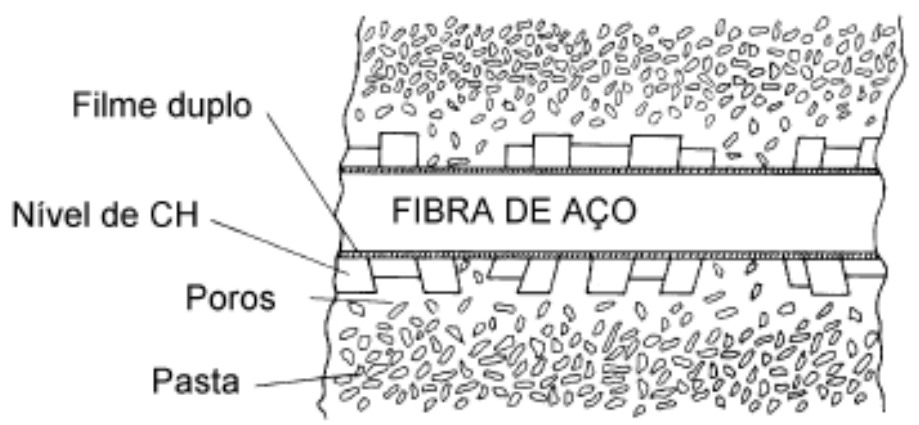

Figura 2.4 - Zona de transição na interface matriz-fibra (BENTUR e MINDESS, 1990)

\subsubsection{Interação fibra-matriz}

A interação entre a fibra e a matriz está relacionada com a transferência de tensões entre a matriz e as fibras. Sabe-se que as fibras de aço, quando adicionadas ao concreto, dificultam a propagação das fissuras, porém é de suma importância entender os mecanismos responsáveis pela transferência de tensões. Isto é importante para possibilitar a previsão da curva tensão-deformação, previsão da eficiência das fibras e previsão do modo de ruptura do concreto. (METHA; MONTEIRO, 2008).

Há grande dificuldade no desenvolvimento de modelos reais para representar o comportamento da transferência de tensões, pois seria necessário considerar a transferência por atrito, a ruptura da aderência por adesão, as tensões e deformações normais e as características reais das fibras, como ondulação e ganchos. Existem modelos analíticos simplificados que avaliam apenas as tensões de cisalhamento que se desenvolvem paralelas à interface matriz-fibra.

Quando o concreto está solicitado por baixos níveis de tensão, as deformações na fibra e na matriz são as mesmas, até a ruptura da matriz, isto é, início da fissuração. No concreto simples, a partir do momento em que surge uma fissura, esta representa uma "barreira" para a propagação de tensões, logo há a tendência de concentração de tensões na extremidade da fissura como indicado na Figura 2.5. Caso esta tensão supere a tensão crítica, ocorrerá a ruptura do material de maneira brusca, caracterizando comportamento frágil do concreto. Já para o concreto com fibras de aço, as fibras servem como ponte de transferência de tensões 
entre as fissuras e, portanto, ocorre a diminuição das tensões na extremidade da fissura e o controle da propagação e abertura das fissuras. Além disso, o concreto deixa de ter comportamento frágil e passa a ter um comportamento pseudo-dúctil, isto é, passa a ter capacidade portante pós-fissuração.
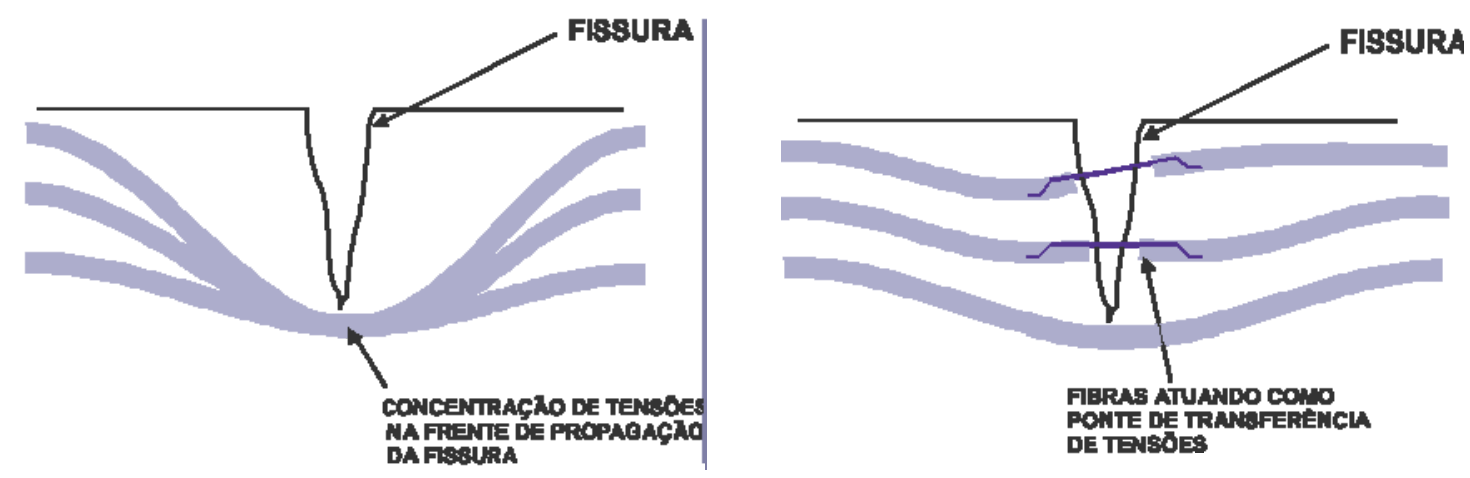

Figura 2.5 - Transferência de tensão. Adaptado (NUNES; AGOPYAN, 1998)

Vale salientar que em estágios mais avançados de carregamento, por exemplo, no estado pós-fissurado, há a ruptura da adesão entre as fibras e a matriz e o processo de transferência de tensões passa a ser controlado pelas tensões de atrito. Desta forma, aparecem deslocamentos longitudinais relativos entre a fibra e a matriz.

A transição da transferência de tensões elásticas para tensões de atrito ocorre de maneira gradual, isto é, os dois mecanismos de transferência ocorrem simultaneamente. Segundo Bastos (1999), se a matriz possui alta resistência à tração a ruptura da adesão entre a matriz e a fibra ocorre antes da fissuração da matriz, entretanto, se possui baixa resistência à tração a fissuração ocorre antes da ruptura da adesão.

Outra característica da interação matriz-fibra está relacionada com a distribuição aleatória das fibras, que promove o reforço em toda a peça e não em uma determinada posição, como é o caso das armaduras convencionais. Esta característica é interessante para estruturas contínuas como os pavimentos, já que as fibras podem reduzir a fissuração devido aos efeitos da retração e secagem.

\subsubsection{Eficiência das fibras}

A capacidade de reforço das fibras depende do teor de fibra utilizado. Quanto maior o teor de fibras no concreto, maior é o número de fibras atuando como ponte de transferência de tensão ao longo da fissura e, portanto maior o reforço no concreto. 
Desta forma, o teor de fibras pode ser considerado como o principal parâmetro definidor do comportamento dos compósitos. No entanto, embora a redução da fissuração esteja diretamente relacionada ao teor de fibras, este fica limitado à possibilidade de misturar adequadamente as fibras à matriz de concreto.

Neste sentido, um conceito importante relacionado à eficiência das fibras é o volume crítico de fibras. Define-se volume crítico de fibras como o teor de fibras que mantém a mesma capacidade resistente para o compósito a partir da ruptura da matriz como ilustrado na Figura 2.6 nas curvas de força vs. deslocamento obtido em ensaios de tração na flexão de prismas de concreto com fibras. (FIGUEIREDO, 2000)

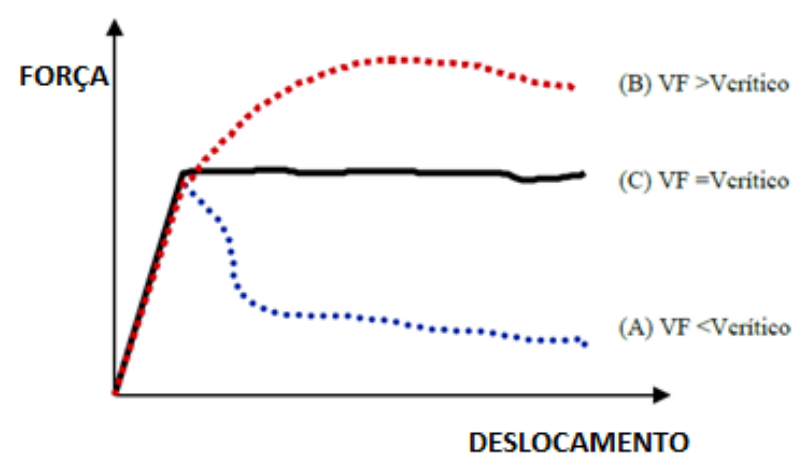

Figura 2.6 - Comportamento dos compósitos reforçados com fibras em função do volume de fibras (FIGUEIREDO, 2000)

Observa-se que abaixo do volume crítico de fibras, há perda de capacidade resistente progressiva após a fissuração da matriz e para um volume de fibras acima do volume crítico ocorre um ganho de capacidade resistente após a fissuração da matriz.

Além disso, a capacidade de absorção de energia e a resistência do concreto com adição de fibras estão relacionadas com o comprimento das fibras de aço. Para avaliação deste efeito é definido um parâmetro, comprimento crítico (Lc), o qual está relacionado com o mecanismo de transferência de tensões entre a fibra e a matriz do concreto.

O comprimento crítico de uma fibra (Lc) corresponde ao dobro do comprimento mínimo da fibra que deve estar envolvido pela matriz de concreto para que as tensões de aderência solicitem a fibra em uma tensão igual à tensão de ruptura desta (Figura 2.7). Para fibras com comprimento menor que o crítico a força de arrancamento devido ao embutimento na matriz é insuficiente para gerar tensão superior à resistência da fibra. Desta forma, com o aumento progressivo da abertura da fissura, a fibra será arrancada no lado com menor comprimento embutido. 
Fibras com comprimentos maiores que o crítico rompem no momento em que a fissura surge, reduzindo a resistência residual. Além disso, fibras com grandes comprimentos dificultam a trabalhabilidade da mistura no concreto fresco. Desta forma, não contribuem para a redução do comportamento frágil do concreto. Portanto, as fibras normalmente utilizadas possuem comprimentos inferiores ao crítico de modo que o processo de arrancamento da fibra garanta tenacidade ao compósito.
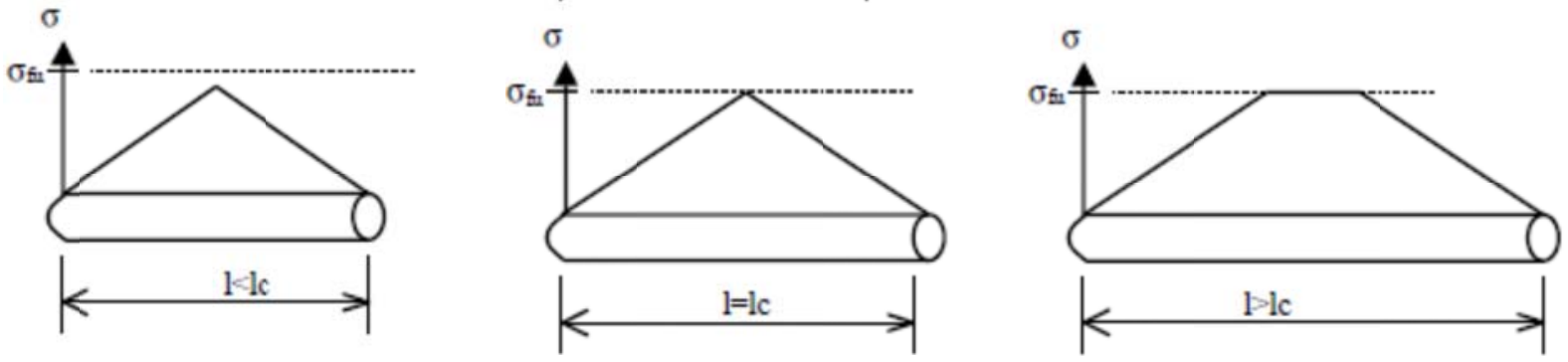

Figura 2.7 - Distribuições de tensões ao longo da fibra em função do comprimento. (Adaptado BENTUR e MINDESS, 1990).

Com base no que foi exposto pode-se dizer que o comportamento e o desempenho do concreto reforçado com fibras depende dos seguintes parâmetros:

- Características do aço da fibra como resistência e módulo de elasticidade;

- Geometria da fibra: ancoragem, fator de forma e comprimento;

- Teor de fibra e;

- Resistência e módulo de elasticidade da matriz cimentícia.

\subsubsection{Comportamento do concreto com adição de fibras}

A adição de fibras ao concreto em taxas inferiores a $2 \%$ em volume tem pouca influência na resistência a compressão e módulo de elasticidade. Todavia observa-se que a introdução de fibras incrementa propriedades do concreto como tenacidade à flexão, fadiga e impacto, ductilidade pós-fissuração e capacidade de absorção de energia pós-pico do concreto.

Para avaliação do desempenho de um material compósito, devem-se observar os mecanismos envolvidos na ruptura, o que pode ser feito por meio do gasto energético envolvido na fratura. Segundo Bentur e Mindess (1990), em concretos reforçados com fibras, grande parte do trabalho total para ruptura está relacionado com a energia dissipada na ruptura 
da aderência entre a fibra e a matriz e posteriormente, no arrancamento das fibras. Desta forma, é possível avaliar o desempenho do concreto com adição de fibras utilizando a quantificação desta energia absorvida.

Os parâmetros relevantes na definição das características do compósito são a tenacidade e a energia de fraturamento.

A tenacidade $\left(\mathrm{T}_{\mathrm{b}}\right)$ geralmente é definida como área total sob a curva tensão por deformação específica. Entretanto no caso dos compósitos há grande dificuldade em determinar a tensão após a fissuração da matriz, desta forma, a tenacidade pode ser interpretada como a área sob a curva força vs. deslocamento (Figueiredo 2000), isto é, o trabalho dissipado no material até certo nível de deslocamento. Entretanto, segundo Figueiredo (2000), esta medida depende do sistema de aplicação das forças e das dimensões do corpo-de-prova.

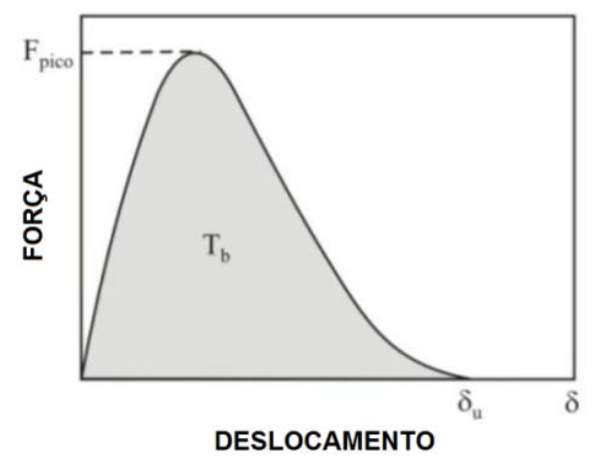

Figura 2.8 - Interpretação da tenacidade

Normalmente realizam-se ensaios de flexão sob quatro pontos de carga em corpos-deprova prismáticos para determinação do índice de tenacidade do material, o qual é calculado pela curva força vs. deslocamento vertical no meio do vão. Um dos métodos é o proposto pela norma japonesa JSCE SF-4:1984, o qual recomenda a determinação da capacidade de absorção de energia até um deslocamento limite, medido no meio do vão, equivalente a L/150, onde L é o vão do corpo-de prova.

Já a energia de fraturamento do concreto é definida como a energia necessária para a abertura de uma fissura de área unitária. O ensaio de determinação da energia de fratura depende do modo de fratura que se deseja avaliar. Para a determinação do modo I, também chamado modo de abertura, pode-se utilizar o ensaio de tração simples ou, mais usualmente, o ensaio de flexão sob três pontos de carga. Neste o corpo de prova prismático possui um entalhe na borda inferior na seção central, com a função de ser um ponto preferencial de formação de uma fissura. 


\subsection{Pesquisas a respeito de Pilares mistos parcialmente revestidos (PMPR)}

\subsubsection{PMPR com seções padronizadas}

Neste item são apresentadas as principais investigações sobre o pilar misto parcialmente revestido composto por perfis padronizados. Entende-se aqui como seção padronizada aquela que não apresenta os efeitos de instabilidades locais, por respeitar a relação entre as largura e espessura das mesas. Em geral, são perfis I ou H que possuem a espessura da alma menor que a espessura da mesa.

\subsubsection{Hunaiti e Abdel Fattah (1994)}

O estudo dos elementos estruturais mistos de aço e concreto pressupõe como hipótese básica o comportamento conjunto entre os componentes da seção transversal. Para isto, é necessário que haja compatibilidade de deformação entre aço e concreto, garantido pelo mecanismo de aderência. Tradicionalmente a aderência natural é dividida em: aderência química, aderência por atrito e aderência mecânica.

A aderência química, também chamada de adesão, representa apenas uma pequena parcela da aderência que surge durante as reações de pega do cimento. Esta parcela atua apenas nos primeiros estágios de carregamento antes do surgimento de deslocamentos. A aderência por atrito se manifesta quando há tentativa de deslocamento relativo entre aço e concreto e depende do coeficiente de atrito dos materiais e da força normal aplicada. Finalmente, a aderência mecânica está relacionada com engrenamento mecânico entre o concreto e as irregularidades na superfície do aço, é relevante enquanto as superfícies de aço e concreto estiverem em contato.

Neste contexto, Hunaiti e Abdel Fattah (1994) testaram 19 pilares parcialmente revestidos submetidos à flexão no eixo de menor inércia, buscando avaliar a existência do comportamento conjunto aço e concreto e a necessidade de conectores de cisalhamento. Os resultados experimentais mostraram que os pilares mesmo quando solicitados a carregamentos excêntricos e sem os conectores de cisalhamento apresentam comportamento conjunto. Além disso, os resultados revelam o mesmo modo de ruptura para todos os pilares ensaiados, caracterizado pelo escoamento do aço combinado com o esmagamento do concreto, acompanhado por grandes deflexões laterais próximas à carga última. As 
capacidades resistentes dos pilares mistos parcialmente revestidos com concreto simples foram muito próximas das obtidas para os pilares com conectores de cisalhamento.

Apesar destes resultados experimentais que atestam o comportamento conjunto na ausência de conectores de cisalhamento, Hunaiti e Abdel Fattah (1994) destacam a importância de utilizar tais conectores em situações de projeto, pois em situações reais a interface entre os dois materiais pode ser alterada por fatores como a idade do concreto e esgotamento dos vínculos entre concreto e aço.

\subsubsection{Pecce e Ceroni (2010)}

Pecce e Ceroni (2010) também analisaram o comportamento do mecanismo de aderência na interface aço-concreto de pilares mistos parcialmente revestidos. Avaliaram-se modelos físicos compostos por perfis metálicos com altura e largura da mesa com $180 \mathrm{~mm}$ parcialmente revestidos por concreto com resistência à compressão de $22 \mathrm{MPa}$ ou $35 \mathrm{MPa}$ submetidos a carregamentos monotônicos de compressão e tração.

Consideraram-se pilares com e sem armadura em forma de barras longitudinais e estribos, além disso, avaliaram a influência da rugosidade da superfície com a aplicação de óleo na superfície antes da concretagem.

Pecce e Ceroni (2010) concluíram por meios dos ensaios de compressão que a parte inicial da curva força vs. deslizamento é fortemente influenciada pelas parcelas de aderência por adesão e por atrito o que resulta em um trecho inicial bastante rígido. Após isto a curva apresenta um pico de máxima força de aderência seguido por um ramo descendente íngreme, finalmente há um trecho final horizontal com força de aderência constante (Figura 2.9). Já os ensaios de tração demostraram que a adesão e a aderência por atrito são menores quando comparados com os ensaios de compressão de modo que são observados deslizamentos consideráveis para níveis de carga mais baixos. Este resultado deve estar relacionado com a tendência de expansão lateral do concreto nos ensaios de compressão o que contribui positivamente para o aumento da parcela de aderência por atrito. 


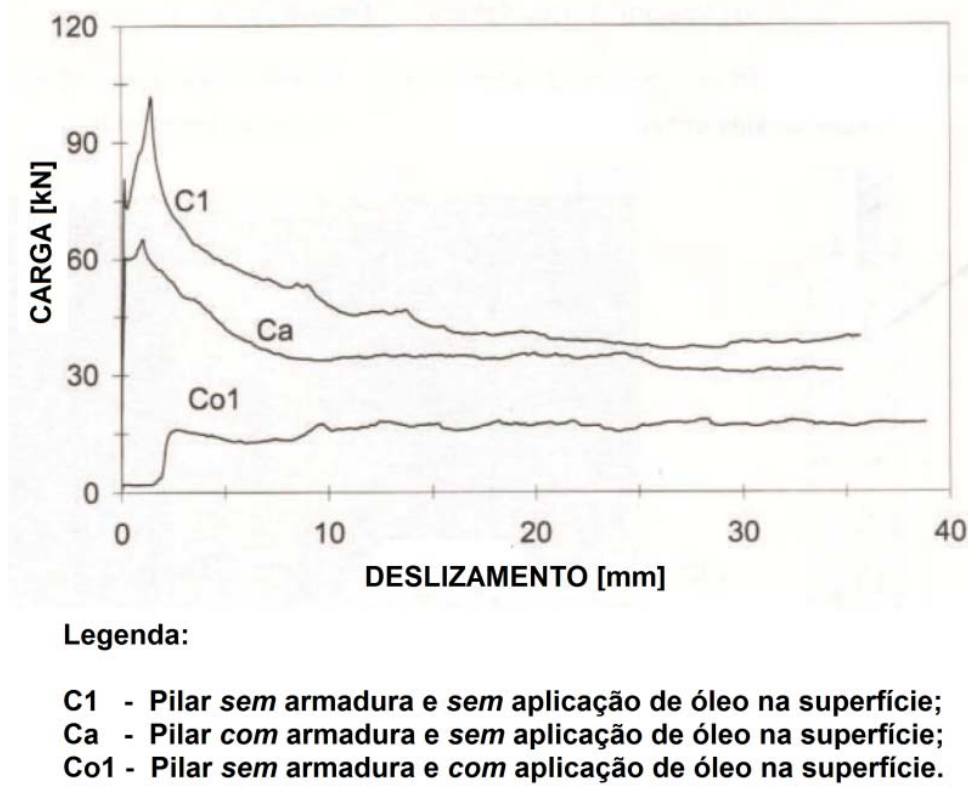

Figura 2.9 - Curva carga vs. deslizamento para pilares mistos submetidos a compressão. (PECCE e CERONI, 2010)

O valor da tensão de aderência é pouco influenciado pela resistência do concreto (quando a resistência à compressão do concreto foi aumentada em $50 \%$ a aderência aumentou 24\%), mas depende fortemente da rugosidade já que reduziu cerca de $50 \%$ com a aplicação do óleo na superfície (Figura 2.9).

Além disso, para investigar o comportamento dos pilares mistos parcialmente revestidos sob ações sísmicas, foram realizados ensaios com carregamentos cíclicos na compressão e na tração. Estes demostraram degradação da rigidez e da resistência na curva tensão vs. deslizamento devido à redução do atrito.

\subsubsection{Korzen, Rodrigues e Correia (2010)}

Em seu trabalho, Korzen, Rodrigues e Correia (2010) avaliaram a capacidade resistente do pilar misto parcialmente revestido submetido a situação de incêndio com deformações impedidas. Os pilares mistos apresentam comportamento diferente dos pilares de aço isolado, pois o concreto tem além da função resistente a função de proteção ao fogo. Neste contexto, um dos objetivos da pesquisa é avaliar se a rigidez da estrutura em torno do pilar influencia na capacidade resistente deste pilar em altas temperaturas. Para isto foram realizados ensaios de resistência ao fogo com restrições axiais na Universidade de Coimbra e no Instituto Federal de Pesquisa e Ensaios de Materiais, em Berlim, Alemanha. 
$\mathrm{Na}$ Universidade de Coimbra o sistema de ensaio é composto por um pórtico de reação de rigidez variável que tinha a função de simular restrição e rigidez semelhantes às condições reais de um edifício. Já no Instituto Federal de Pesquisa e Ensaios de Materiais, em Berlim, o sistema de ensaio era composto apenas pelo pilar misto isolado e o forno. As ações mecânicas e térmicas eram aplicadas ao pilar por meio de dispositivos (controle eletro-hidráulico) no forno, de modo a simular os esforços oriundos da estrutura que envolve o pilar, como uma estrutura virtual.

Os autores observaram respostas semelhantes ao comparar os dois métodos de ensaios. A principal diferença observada está no fato que a amostra no forno do Instituto Federal de Pesquisa e Ensaios de Materiais, em Berlim, é aquecida ao longo de todo o seu comprimento enquanto no forno na Universidade de Coimbra cerca de $8 \%$ em cada extremidade não é aquecida. Desta forma, a resistência ao fogo mostrou-se menor para o forno em Berlim.

Pode-se concluir que a estrutura que envolve a coluna tem influência no desenvolvimento de forças axiais nos pilares ensaiados, de modo que quanto maior a rigidez da estrutura envolvente maior são as forças axiais geradas durante a ação do fogo.

\subsubsection{PMPR fabricado com seções soldadas de chapa fina}

Na década de 1990 o Grupo Canam Manac Inc. desenvolveu um novo tipo de pilar misto parcialmente revestido com o objetivo de torná-lo mais econômico, especialmente para edifícios altos de aço, onde suportaria apenas as cargas verticais enquanto outros elementos seriam responsáveis por resistir aos esforços de vento. O custo seria reduzido pela diminuição do consumo de aço obtida por meio do aumento da contribuição do concreto para compor a capacidade resistente do elemento, de modo que o perfil metálico era projetado apenas para resistir às solicitações de construção e uma pequena parcela da solicitação total.

Este novo tipo de pilar parcialmente revestido é composto por três chapas finas de aço soldadas formando uma seção H (Figura 2.10). Entre as mesas do perfil de aço são soldadas barras transversais, igualmente espaçadas ao longo do comprimento do pilar, visando apoiar lateralmente as extremidades sem suporte do perfil metálico. Além disso, aumentam a resistência à instabilidade dos perfis e proporcionam confinamento ao concreto nestas regiões (VINCENT, 2000; VINCENT; TREMBLAY, 2001). 


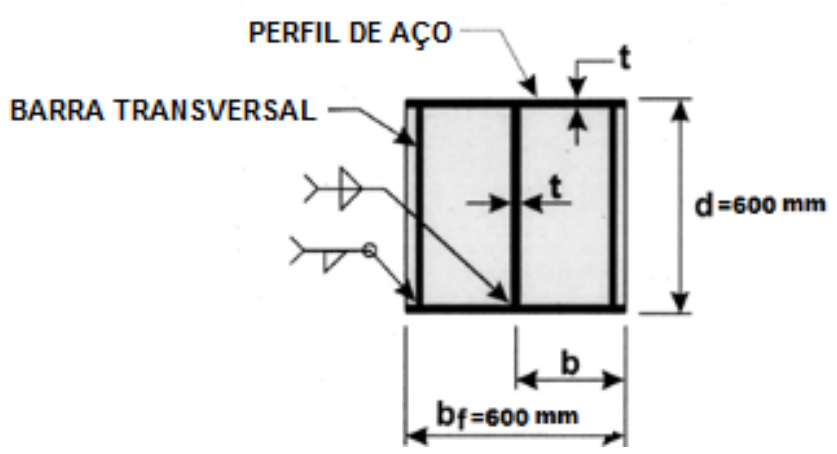

Figura 2.10 - Pilar misto parcialmente revestido composto por chapas finas (VINCENT e TREMBLAY, 2001).

Foi desenvolvido um programa experimental por quatro universidades norteamericanas (École Polytechnique em Montreal; Lehigh University em Bethlehem; University of Toronto e McGill University em Montreal) com o objetivo de estudar o comportamento dos pilares, como modos de ruptura, flambagem local e expansão lateral do concreto, investigar o efeito de parâmetros como o espaçamento, tamanho e forma das barras transversais e avaliar a influência das cargas de construção na capacidade resistente do elemento. Além disso, buscava-se propor diretrizes e equações de dimensionamento. Neste contexto, destacam-se alguns trabalhos: Vincent (2000), Vincent e Tremblay (2001), Chicoine et al. (2002), Tremblay, Chicoine e Massicote (2002), Chicoine Tremblay e Massicote (2003).

Ao todo, foram estudados 26 pilares curtos, divididos em três séries de ensaios: a série de ensaios $\mathrm{S}$ composta por 10 pilares de aço isolado, a série $\mathrm{C}$ formada por 11 pilares mistos e a finalmente a série $\mathrm{P}$ onde sete pilares mistos foram ensaiados segundo a sequência de construção prevista. Além disso, foram ensaiados quatro pilares esbeltos sendo um pilar de aço isolado (SL-1) e 3 pilares mistos (CL-1, 2 e 3) (TREMBLAY; CHICOINE; MASSICOTTE (2002); CHICOINE; MASSICOTE ; TREMBLAY (2003)).

Após isto, outros autores realizaram ensaios complementares os realizados pelo Grupo Canam Manac, como Prickett e Driver (2006) e Oh et. al (2006).

\subsubsection{Elnashai e Broderick (1994a; 1994b)}

Elnashai e Broderick (1994a; 1994b) investigaram o comportamento estrutural de pilares mistos parcialmente revestidos sob o efeito combinado de sismos e cargas axiais variadas por meio de ensaios experimentais cíclicos e pseudo-dinâmicos num total de sete pilares parcialmente revestidos. 
Nos testes cíclicos, os modelos físicos foram submetidos a uma força axial de $15 \% \mathrm{e}$ $30 \%$ da capacidade resistente. Já nos ensaios pseudo-dinâmico, os modelos foram submetidos ao efeito combinado de uma carga axial e de uma ação sísmica (sismo de El Centro de 1940, sismo de San Salvador de 1986 e sismo de Montenegro de 1979).

Buscava-se avaliar o comportamento estrutural nestas situações e também as características geométricas da seção transversal relevantes, como por exemplo, a presença de armadura transversal. Foram avaliados modelos onde havia apenas as barras transversais, como as da Figura 2.10, e modelos onde além destas barras havia armadura transversal na forma de estribos. Comparando-se as alternativas observou-se que não havia mudança significativa na capacidade resistente da seção transversal, já que o confinamento não era drasticamente afetado.

Os resultados experimentais demonstraram excelente desempenho do elemento misto e reafirmam a possibilidade de utilização de elementos mistos para edifícios de múltiplos pavimentos em locais com ocorrência de sismos.

\subsubsection{Tremblay, Chicoine e Massicotte (2002)}

Tremblay, Chicoine e Massicote (2002) apresentaram, entre outras coisas, que a ruína dos pilares da série $\mathrm{S}$, isto é, pilares de aço isolados, ocorria após a flambagem local das mesas e alma do perfil metálico. Observou-se que o modo de instabilidade era influenciado pela presença e espaçamento das barras transversais. Já o pilar SL-1, mais esbelto, teve a ruptura devido aos efeitos combinados dos fenômenos de instabilidade local e global.

\subsubsection{Chicoine et al. (2002)}

Chicoine et al. (2002) investigaram pilares mistos parcialmente revestidos compostos de chapas finas (Série C) com as propriedades dos materiais e procedimentos de ensaio similares aos desenvolvidos por Tremblay et al. (1998), entretanto utilizando seções transversais maiores. O objetivo principal da pesquisa era comparar seus resultados com aqueles obtidos no estudo de Tremblay et al. (1998), com a finalidade de quantificar a influência das dimensões da seção transversal na capacidade resistente à compressão.

Neste estudo, avaliou-se o comportamento de cinco pilares mistos parcialmente revestidos com seção transversal de dimensões 600 x 600 mm, altura de 3m (Figura 2.11), em 
complemento aos estudos por Tremblay et al. (1998) com dimensões da seções de 450 x 450 $\mathrm{mm}$ e $300 \times 300 \mathrm{~mm}$ (totalizando 11 pilares avaliados).

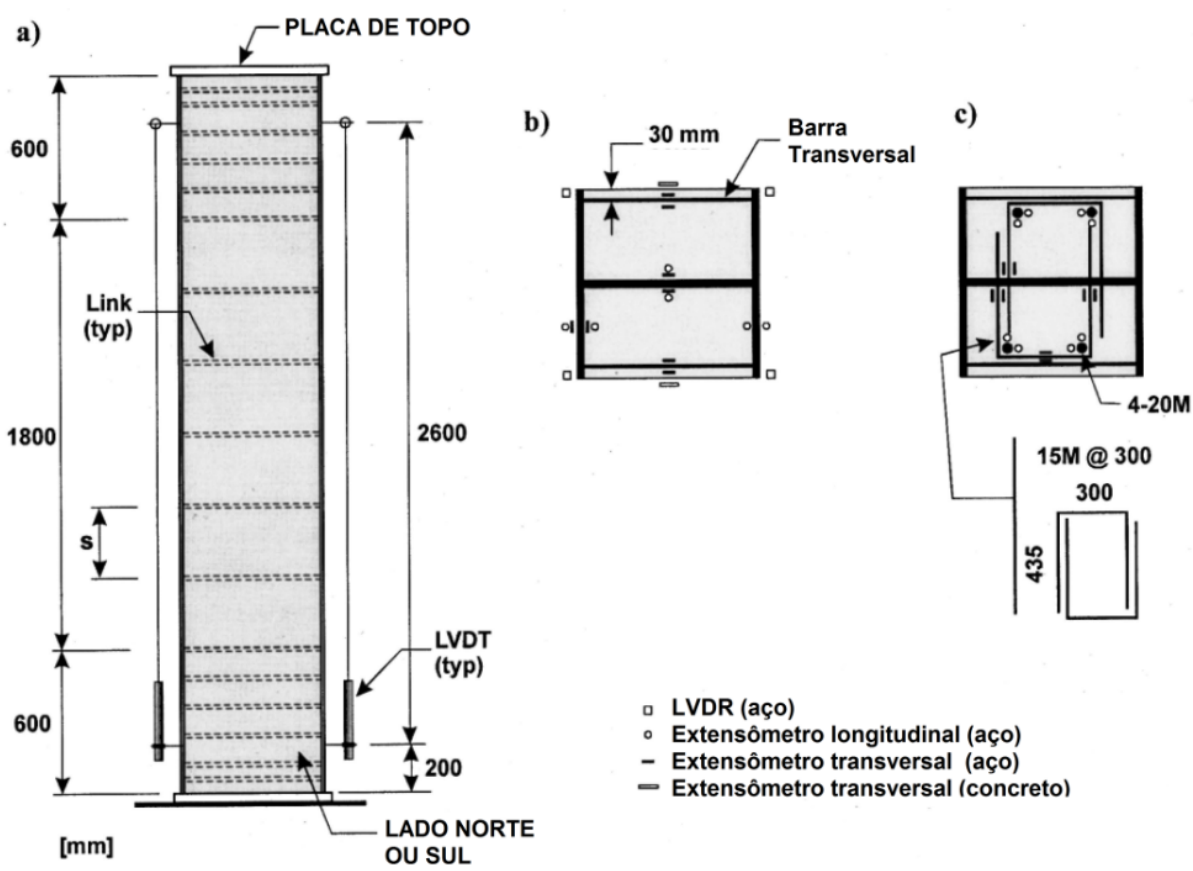

Figura 2.11 - Geometria e instrumentação a) Elevação; b) Seção transversal típica; c) Seção transversal com armadura adicional para o modelo C-12 (CHICOINE et. al., 2002)

A Tabela 2.2 apresenta as propriedades dos modelos investigados por Chicoine et. al. (2002). Foram utilizadas barras transversais de $16 \mathrm{~mm}$ soldadas entre as mesas do perfil de aço. Nos modelos C-8 a C-12 foram utilizadas barras transversais adicionais, além de concreto com maior resistência em uma região de altura d dos extremos do pilar, para prevenir que a ruptura ocorresse neste local devido à possibilidade de haver um carregamento desigual.

Tabela 2.2 - Propriedade dos modelos avaliados por Chicoine et. al. (2002)

\begin{tabular}{cccccccccc}
\hline Modelo & $\boldsymbol{b}_{\boldsymbol{f}} \boldsymbol{x} \boldsymbol{d}$ & $\boldsymbol{T}$ & $\boldsymbol{b}_{\boldsymbol{f}} / \mathbf{t}$ & $\boldsymbol{s}$ & \multicolumn{2}{c}{$\boldsymbol{\delta}_{\boldsymbol{0}}(\mathbf{m m})$} & $\boldsymbol{f}_{\boldsymbol{y}}$ & $\boldsymbol{f}_{\boldsymbol{c}}$ & $\boldsymbol{P}_{\text {u,exp. }}$ \\
\hline & $(\mathrm{mm})$ & $(\mathrm{mm})$ & & $(\mathrm{mm})$ & $\mu$ & $\sigma$ & $(\mathrm{MPa})$ & $(\mathrm{MPa})$ & $(\mathrm{kN})$ \\
$\mathbf{C - 8}$ & $600 \times 600$ & 12,88 & 23,3 & 600 & 1,43 & 1,38 & 360 & 34,2 & 16470 \\
$\mathbf{C - 9}$ & $600 \times 600$ & 12,91 & 23,2 & 600 & 2,02 & 0,36 & 360 & 34,2 & 16610 \\
$\mathbf{C - 1 0}$ & $600 \times 600$ & 12,81 & 23,4 & 300 & 0,38 & 0,15 & 360 & 34,2 & 16240 \\
$\mathbf{C - 1 1}$ & $600 \times 600$ & 9,71 & 30,9 & 600 & 0,71 & 0,46 & 345 & 34,2 & 14930 \\
C-12 & $600 \times 600$ & 12,86 & 23,3 & 300 & 0,37 & 0,15 & 360 & 34,2 & 17450 \\
\hline
\end{tabular}

$\mathrm{s}$ - Espaçamento entre as barras transversais;

$\delta_{0}$ - Imperfeições iniciais nas chapas; 
$P_{u, \text { exp. }}-$ Carga última esperada.

Observou-se ainda que os modelos de $450 \mathrm{~mm}$ e $600 \mathrm{~mm}$ apresentaram comportamento semelhante. Quando comparados com modelos maiores com as mesmas características, os modelos de $300 \mathrm{~mm}$ não apresentaram flambagem local antes da força de pico e tiveram falha mais gradual, porém exibiram a mesma resposta pós-pico. A partir dos resultados obtidos, Chicoine et al. (2002) afirmam que as dimensões das seções transversais dos pilares não afetam diretamente o comportamento e a capacidade resistente dos mesmos, já que os resultados obtidos eram similares aos apresentados por Tremblay et al. (1998) em termos de modos de falha e comportamento pós pico. Foi observado em todos os casos que a ruptura se dá pelo esmagamento do concreto combinado com a instabilidade local das abas do perfil de aço.

A Figura 2.12 apresenta o gráfico: Força aplicada vs. deformação axial média no pilar. Esta última corresponde ao encurtamento médio da coluna medido pelos transdutores longitudinais localizados nos quatro cantos de cada modelo dividido pela distância entre pontos de fixação.

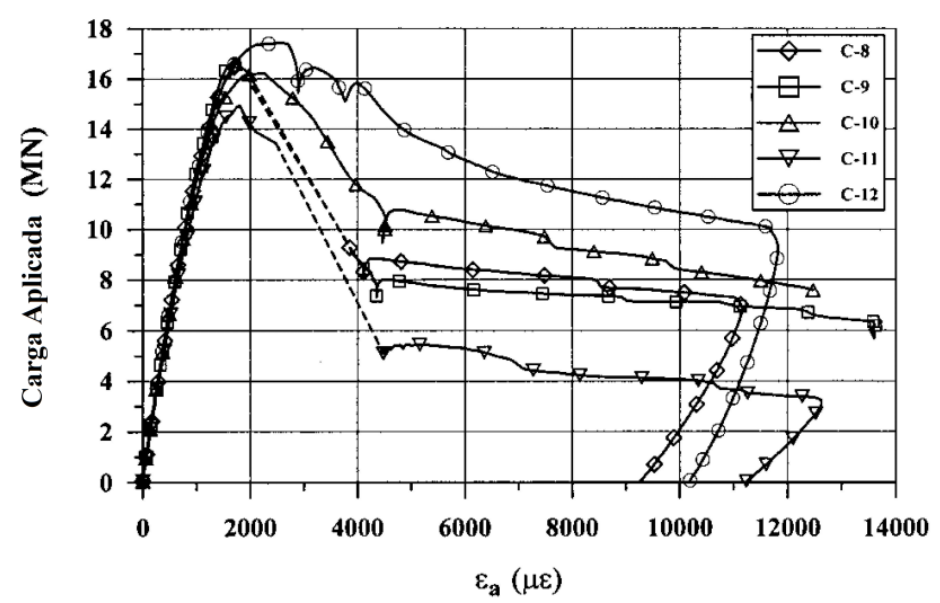

Figura 2.12 - Curva Força x Deformação média para os modelos (CHICOINE et. al., 2002)

Nos modelos onde as barras transversais tinham um espaçamento igual a " $d$ " $(d=$ profundidade do pilar), a flambagem local aparece aproximadamente com $75 \%$ da força de pico. Nestes modelos a falha ocorreu pelo esmagamento do concreto e a flambagem local de forma frágil e repentina. Já nos modelos onde as ligações transversais tinham um espaçamento igual a " $\mathrm{d} / 2$ ”, os sinais de flambagem local só puderam ser vistos logo antes de atingir a força de pico. Novamente observou-se que a falha destes modelos ocorreu pelo esmagamento do concreto e a flambagem local, entretanto de maneira mais dúctil e 
progressiva do que nos modelos com maior espaçamento. Além disto, para alguns modelos houve falha na solda das barras transversais. Verificou-se, portanto que as barras transversais adicionais melhoram a ductilidade e a resposta pós-pico do pilar, mas não há ganho na capacidade resistente. Desta forma, os autores sugerem que as distâncias entre as barras transversais não devem superar a metade da altura da seção transversal.

\subsubsection{Chicoine, Massicote e Tremblay (2003)}

Chicoine, Massicote e Tremblay (2003) avaliaram o comportamento estrutural de pilares mistos parcialmente revestidos com chapas finas sob a ação das cargas aplicadas na sequência típica de construção e ação de cargas de longo prazo. Além disso, avaliaram o efeito da retração e fluência nas deformações e tensões no aço e concreto.

Foram estudados cinco pilares com seção transversal de 300 x $300 \mathrm{~mm}$ e dois com seção de 450 x $450 \mathrm{~mm}$. Para cada modelo, a fim de determinar a evolução da deformação axial com o tempo, mediram-se as deformações durante o período de aproximadamente 150 dias. Cinco dos modelos foram carregados até a ruína e quatro foram carregados de acordo com a sequência de construção prevista seguindo três estágios. No estágio 1 foi aplicada uma carga P1 no perfil metálico para introduzir uma tensão nominal de $100 \mathrm{MPa}$. No estágio 2, após 14 dias da concretagem, a carga aplicada é aumentada produzindo uma tensão de aproximadamente $170 \mathrm{MPa}$ no aço e 10MPa no concreto. Esta carga é mantida por 150 dias. Finalmente no estágio 3 a carga é aumentada até a ruptura.

Para os modelos ensaiados até a carga última observou-se que o início da flambagem local deu-se logo antes ou logo após a carga de pico. A ruína ocorreu de forma dúctil e progressiva ao contrário do modo de falha observado por Chicoine et. al. (2002) em modelos com seções transversais de altura igual a $600 \mathrm{~mm}$ ensaiados com o mesmo carregamento.

Além disso, observou-se que os modos de falha foram os mesmos entre os modelos analisados com carga de longa duração e curta duração, isto é, esmagamento do concreto entre duas barras transversais junto com a flambagem local das abas do perfil de aço. A falha ocorreu em ambas as faces quase que simultaneamente, mas em alturas diferentes do modelo. Verificou-se também que a carga última foi aproximadamente a mesma, independente da forma de aplicação da carga sugerindo que a retração e a fluência do concreto não tiveram efeito significativo. 


\subsubsection{Prickett e Driver (2006)}

Em seu trabalho Prickett e Driver (2006) avaliaram a influência da resistência do concreto no comportamento de pilares mistos parcialmente revestidos com chapas finas. Foram utilizados concretos com resistência à compressão de $60 \mathrm{MPa}$ e $30 \mathrm{MPa}$, e em dois modelos foram adicionadas fibras de aço para avaliar os possíveis benefícios na ductilidade e resposta pós-pico. Os resultados mostraram que pilares com concreto de resistência usual possuem maior ductilidade que aqueles com concreto de alta resistência. Porém, aproximando as barras transversais e adicionando fibras de aço ao concreto de alta resistência, os pilares revestidos por este concreto terão ruptura mais dúctil.

Nos ensaios com forças concentradas e com forças excêntricas o modo de ruptura verificado por Prickett e Driver (2006) é semelhante ao já descrito por Tremblay et al. (1998) e Chicoine et al. (2003), isto é, esmagamento do concreto combinado com flambagem local nas mesas. Já o modo de falha dos pilares submetidos a forças excêntricas depende do eixo de flexão. Quando a flexão ocorre em torno do eixo de maior inércia, nota-se que a máxima compressão e as tensões elásticas das fibras concentram-se no aço e a formação de fissuras ocorria de forma gradual devido ao confinamento garantido ao concreto pelas mesas do perfil de aço. Já quando o eixo de flexão encontra-se no eixo de menor inércia, o modo de falha se caracterizava pela perda repentina da resistência.

\subsubsection{Oh et. al. (2006)}

Oh et. al. (2006) realizaram ensaios em quatro pilares mistos parcialmente revestidos com barras transversais submetidos a esforços de compressão e flexão simultâneos. Foi utilizado um atuador para aplicar uma força axial e outros dois atuadores para gerar uma dupla curvatura. Todos os modelos usados tinham 350 x $350 \mathrm{~mm}$ e $4440 \mathrm{~mm}$ de comprimento, mesa e alma com $7 \mathrm{~mm}$ de espessura e a relação largura/espessura era de 25 .

Durante o carregamento axial, não foi observado fissuração em nenhum modelo. Quando os pilares foram solicitados por esforços de flexão foi observado o surgimento de fissuras que aumentaram em número e tamanho com o aumento da solicitação no concreto especialmente na região tracionada. Com o aumento do deslocamento houve a separação gradual da superfície de contato do concreto e do aço resultando esmagamento do concreto e logo após isto a flambagem local da mesa do perfil metálico entre as barras transversais. A Figura 2.13 mostra a falha padrão de um dos modelos analisados por Oh et. Al. (2006). 


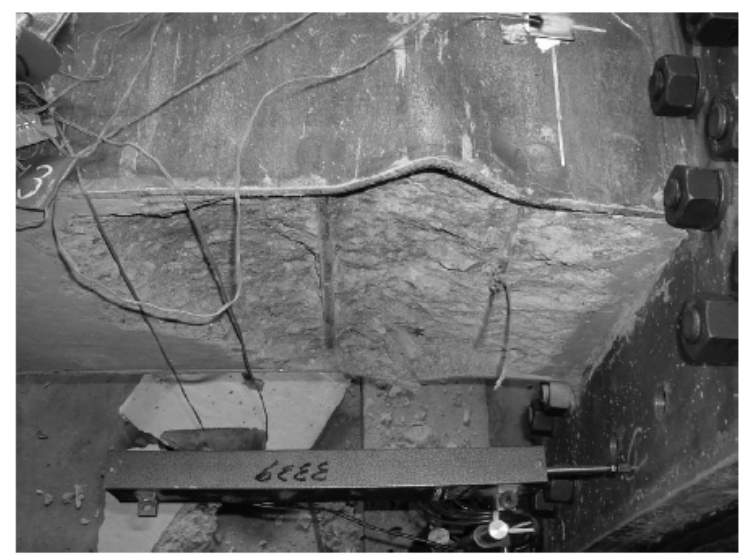

Figura 2.13 - Falha padrão de um dos modelos analisados (B4-WP40). (OH et. al., 2006)

Para a flexão no eixo de maior inércia o momento se torna maior com o aumento da carga axial, enquanto o correspondente momento se torna menor no caso da flexão no eixo de menor inércia.

\subsubsection{Simulações numéricas}

\subsubsection{Chen et. al (2010)}

Apesar do mecanismo do concreto nos pilares mistos parcialmente revestidos ser tridimensional, Chen et. al (2010) desenvolveram um modelo numérico simplificado. Para simular a complexa interação entre o aço e o concreto em um elemento misto o comportamento do concreto é separado em longitudinal e transversal. A seguir são apresentados os aspectos relevantes adotados no modelo numérico:

- Foram realizadas análises considerando a não linearidade física e geométrica;

- O perfil metálico foi simulado por meio de elementos de casca e para a relação constitutiva do material considerou-se uma relação bilinear com encruamento cinemático;

- Para simular a função do concreto de resistir a cargas de compressão e de tração foram empregadas molas verticais de tração e compressão;

- Para simular a função do concreto de inibir a flambagem local das chapas do perfil foram empregadas molas transversais de compressão, apenas;

- Foram criados conectores imaginários fixando a mola transversal que representa o concreto ao perfil metálico, de modo a garantir que não haja deslocamento do ponto médio destas molas; 
- As barras transversais entre as mesas do perfil foram simuladas utilizando molas de tração;

- Para simular o comportamento das barras da armadura longitudinal antes da fissuração do concreto foram empregadas molas de compressão e tração. Após a fissuração do concreto estas molas passam a ter capacidade de resistência apenas à tração.

As comparações com os resultados experimentais demostraram que a adoção de um modelo simplificado é factível. Mesmo o concreto sendo representado por uma combinação de funções uniaxiais foi possível obter uma simulação satisfatória para o comportamento do pilar misto parcialmente revestido, uma vez que a restrição da flambagem local só induz uma pequena força na direção horizontal a qual não afeta as propriedades do concreto na direção vertical .

\subsubsection{Begum e Ghosh (2011)}

Begum e Ghosh (2011) obtiveram a seção de aço equivalente para oito pilares mistos parcialmente revestidos ensaiados por Tremblay et. al. (1998) e Chicoine et. al. (2002). Com estas seções de aço equivalentes realizaram uma simulação numérica no software ABAQUS onde os pilares foram submetidos à compressão axial e os resultados comparados com os resultados experimentais e com os resultados obtidos de uma simulação numérica onde a seção mista fora discretizada em elementos de aço e concreto. As simulações com a seção de aço equivalente obtiveram boa correlação com os resultados experimentais e o modelo numérico com a seção mista até a carga limite. Entretanto após a carga limite o modelo proposto por Begum e Ghosh (2011) apresenta valores de deformação mais baixos que os obtidos experimentalmente. Isto se deve ao fato da formulação da seção equivalente considerar o material com comportamento elástico linear e, portanto, não considerar o comportamento real, não linear do material concreto.

\subsubsection{Ellobody e Young (2011)}

Ellobody e Young (2011) desenvolveram um modelo tridimensional não linear em elementos finitos (elementos sólidos) para investigar o comportamento de pilares mistos de aço revestidos submetidos a carregamento axial. A seguir são apresentados os aspectos relevantes adotados no modelo numérico: 
- As extremidades dos pilares foram consideradas como apoiadas. Isto foi simulado por meio de chapas rígidas posicionadas nas extremidades, as quais eram livres para girar em relação ao eixo paralelo à seção transversal;

- Foi adotado para o comportamento dos materiais relações não-lineares (aço, concreto e barras da armadura);

- O efeito do confinamento do concreto é promovido pelo perfil metálico e barras da armadura. Por isso, foram consideradas três zonas de confinamento: concreto fortemente confinado adjacente ao perfil, concreto parcialmente confinado e concreto não confiando;

- As superfícies entre o aço do perfil e o concreto e entre as barras da armadura e o concreto foram discretizadas com elementos de interface a fim de possibilitar a avaliação do comportamento da aderência nestas interfaces;

- Consideração das imperfeições geométricas iniciais.

O modelo numérico desenvolvido foi calibrado utilizando resultados experimentais disponíveis na literatura. Observou-se boa correlação entre os resultados obtidos para a capacidade resistente do pilar misto com o modelo numérico e com os ensaios experimentais, além disso, o modelo numérico representou adequadamente o modo de falha observado experimentalmente. Ao se comparar a capacidade resistente obtida pelo modelo numérico com a obtida pelos procedimentos propostos pelo Eurocode 4:2004 notou-se que os modelos simplificados dos códigos normativos representam satisfatoriamente os pilares quando respeitados os limites de aplicabilidade descritos na norma. Já os valores obtidos pelo AISC:2005 se mostram conservativos para os pilares mistos revestidos.

\subsection{Ligações entre o pilar misto e demais elementos estruturais}

Apesar das vantagens dos elementos mistos em aspectos estruturais, construtivos e econômicos apresentadas no Capítulo 1, a principal preocupação com estes elementos está associada à ligação do elemento misto com outros elementos estruturais. As preocupações com as ligações estão relacionadas às características estruturais e construtivas, pois estas devem garantir a compatibilidade de deslocamentos entre o aço e concreto no ponto de introdução de carga por meio de detalhes simples, de fácil execução e, preferencialmente, baixo custo.

Para seções totalmente revestidas a ligação é feita diretamente no perfil de aço, com a viga passando através do concreto (MUISE, 2000). Em pilares preenchidos, segundo De 
Nardin (2003), os detalhes de ligações disponíveis na literatura internacional são, na maioria, desenvolvidos para perfis tubulares laminados. No Brasil, os perfis tubulares são geralmente obtidos da associação de dois perfis U, desta forma, De Nardin (2003) propõe algumas alternativas apropriadas à realidade brasileira. As tipologias de ligação são mostradas na Figura 2.14. Para a tipologia (a) foi considerada a situação com aderência entre os parafusos e o núcleo de concreto e a situação sem aderência entre eles. Ao se comparar estas situações verificou-se que não havia alterações na capacidade resistente devido à existência de aderência, mas ocorriam alterações nas distribuições de deformação na chapa de topo. Ao se comparar a tipologia (b) e (c), De Nardin (2003) concluiu que a adição de cantoneiras internas na região tracionada da ligação viga-pilar preenchido contribui para o aumento da rigidez e da capacidade resistente e para a redução das deformações.

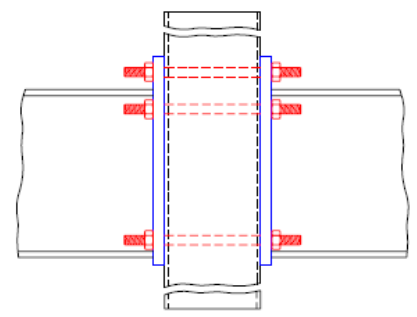

a) ligação parafusada - chapa de extremidade + barras rosqueadas

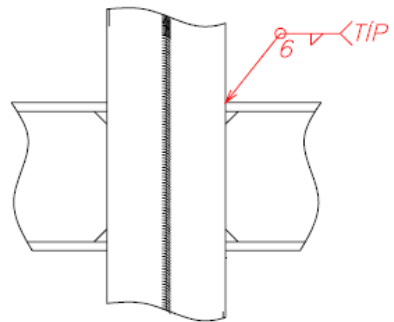

b) ligação soldada

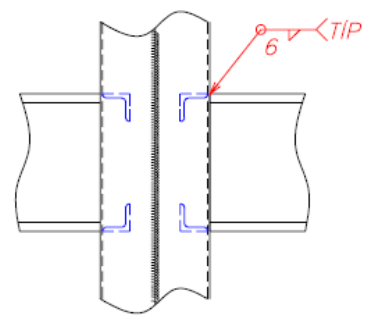

c) ligação soldada + cantoneiras enrijecedoras

Figura 2.14 -Detalhe de ligação entre pilares preenchidos e viga I de aço. (DE NARDIN, 2003)

Em pilares mistos parcialmente revestidos a execução das ligações é feita, geralmente, no perfil metálico. Para ligações viga-pilar no eixo de maior inércia, as vigas podem ser conectadas ao pilar por meio da mesa do perfil metálico ao qual fica exposta segundo várias configurações (Figura 2.15).
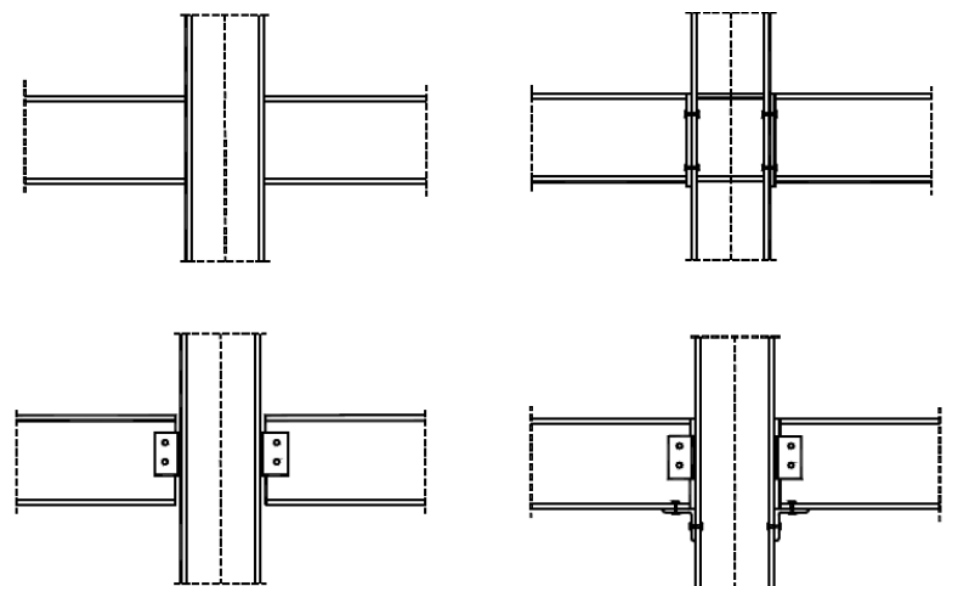

Figura 2.15 -Possibilidades de ligações viga-pilar misto parcialmente revestido. (MUISE, 2000) 
A dificuldade está na execução de ligações viga-pilar no eixo de menor inércia e em ligações pilar-pilar em estruturas de múltiplos pavimentos. Neste caso, a concretagem, normalmente executada na horizontal, deve ser interrompida na região da ligação para ter se acesso ao perfil metálico assim poderão ser executadas. Com esta interrupção muitas vezes é necessário o uso de conectores de cisalhamento para garantir o comportamento conjunto dos materiais no elemento. A Figura 2.16 mostra a concretagem da região da ligação executada apenas com a estrutura já montada.
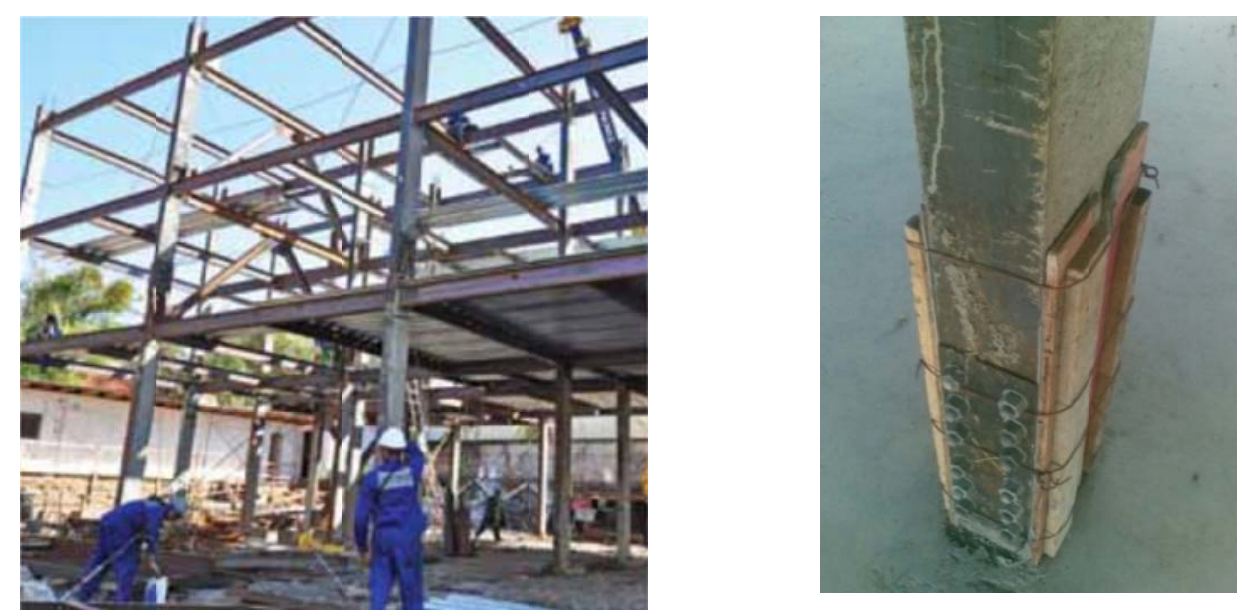

Figura 2.16 - Concretagem interrompida na região da ligação. (ARQUITERUTA \& AÇO, 2013)

Muise (2000) estudou uma configuração de ligação no eixo de menor inércia para pilares mistos parcialmente revestidos com chapas finas de aço. A ligação é feita utilizando-se uma chapa de topo exterior como indicada na Figura 2.17. Como não é interrompido o revestimento de concreto não há a necessidade de mecanismos de ancoragem adicional, como conectores de cisalhamento, para as situações estudadas. Segundo Muise (2000), precauções extras devem ser tomadas para casos com momento aplicado ou forças horizontais.

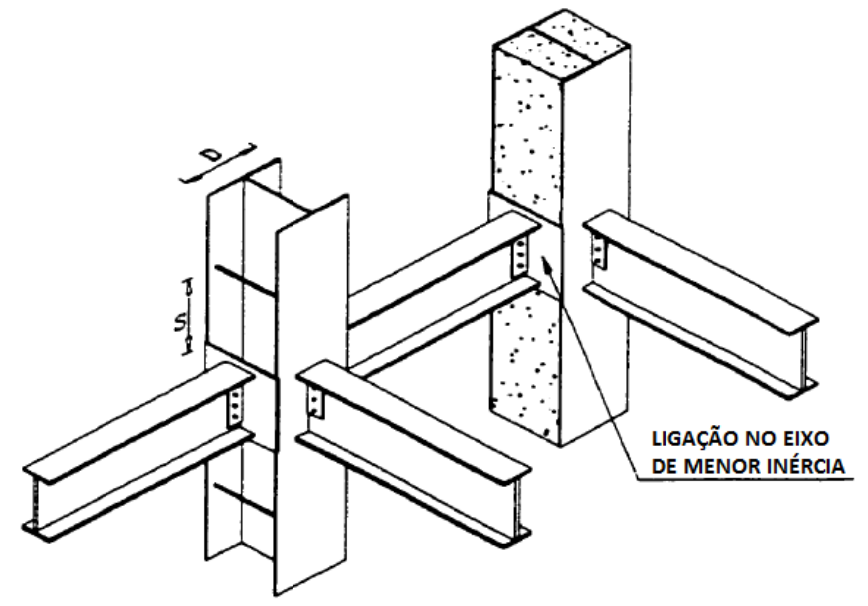

Figura 2.17 - Ligação no eixo de menor inércia. (MUISE, 2000) 


\subsection{Panorama Nacional}

No Brasil, um dos primeiros estudos experimentais em pilares mistos foi em São Carlos, na EESC-USP, com o trabalho de De Nardin (1999). Este estudo objetivava a avaliação da capacidade resistente e comportamento pós-pico do pilar misto preenchido. Além disso, pretendia-se analisar os parâmetros que afetam o confinamento promovido por tubos metálicos ao núcleo do concreto. $\mathrm{Na}$ sequência outro programa experimental foi desenvolvido por De Nardin (2003) para avaliar pilares mistos preenchidos, com seção quadrada, submetidos à compressão excêntrica. Com estes estudos verificou-se que a ruína ocorre pelo esmagamento do núcleo de concreto e escoamento do aço do perfil. Depois de ocorrida a perda da parcela resistente do concreto há a flambagem local do perfil tubular que passou a suportar toda a tensão atuante.

Dando continuação às pesquisas desenvolvidas no departamento de estruturas da EESC-USP, Oliveira (2008) realizou um amplo programa experimental do comportamento de pilares mistos preenchidos de seção circular. Avaliou a influência da resistência do concreto, da esbeltez do pilar, da espessura do tubo e forma de introdução do carregamento (no concreto ou na seção mista) no comportamento estrutural do elemento misto. Concluiu que o modo de falha depende da esbeltez global e local dos pilares. Para pilares com menores razões $\mathrm{L} / \mathrm{D}$, isto é, pilares menos esbeltos, a ruína ocorre por esmagamento do concreto em conjunto com posterior flambagem local do perfil. Enquanto para pilares muito esbeltos a ruína ocorre por cisalhamento ou instabilidade global. Além disso, notou-se que o efeito do confinamento promovido pelo tudo metálico contribui para a ductilidade dos pilares mistos, sem ganhos significativos na capacidade resistente. Entretanto, pilares esbeltos tem uma redução na ductilidade independente da resistência do concreto. Outro aspecto relevante na capacidade resistente é o sistema de aplicação do carregamento que quando aplicado somente no concreto traz ganhos a capacidade resistente em todas as situações estudadas.

Já Mantovani (2006) investigou experimentalmente pilares mistos parcialmente revestidos em escala real. Foram ensaiados seis pilares mistos, com $3000 \mathrm{~mm}$ de altura, submetidos a ensaio de flexo-compressão com ênfase na zona de introdução de carga (ZIC's). As zonas de introdução de cargas são as regiões que recebem esforços localizados devido a reações de vigas, reações da base dos pilares ou ainda transição de pilares.

As características dos pilares ensaiados são apresentadas na Figura 2.18 e Tabela 2.3. Todos os modelos ensaiados possuem armadura longitudinal composta por quatro barras de diâmetro igual a $8 \mathrm{~mm}$ e estribos de $6,3 \mathrm{~mm}$ de diâmetro dispostos a cada $120 \mathrm{~mm}$. Além 
disso, na região da ligação foram utilizados oito conectores de cisalhamentos de $75 \mathrm{~mm}$ de comprimento com diâmetro igual a $19 \mathrm{~mm}$, dispostos quatro em cada face da alma do perfil.

Tabela 2.3 - Modelos ensaiados por Mantovani (2006)

\begin{tabular}{cr}
\hline Modelo & Características \\
\hline MSM & $\begin{array}{r}\text { Perfil tipo I de } 200 \times 200 \mathrm{~mm} \text { simulando ligações de duas vigas, descarregando reações de } \\
\text { apoio nos dois lados das mesas do pilar. }\end{array}$ \\
MAA & Perfil tipo I de $200 \times 200 \mathrm{~mm}$ simulando ligações de vigas, descarregando reações de \\
apoio em um dos lados da alma do pilar misto. & Perfil tipo I de $200 \times 200 \mathrm{~mm}$ simulando ligações de duas vigas, descarregando reações de \\
MAM & Perfil tipo I de $200 \times 200 \mathrm{~mm}$ simulando ligações de vigas, descarregando reações de \\
& apoio em apenas um dos lados da mesa do pilar.
\end{tabular}
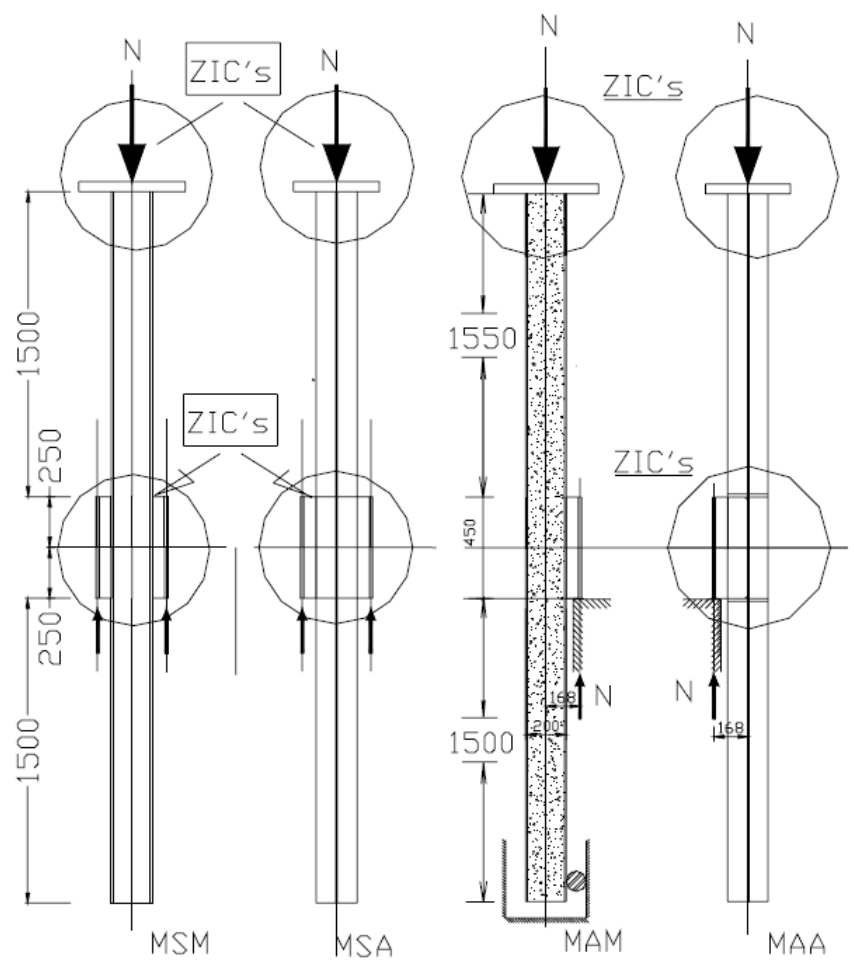

Figura 2.18 - Modelos ensaiados por Mantovani (2006)

Mantovani (2006) verificou que mesmo para altas cargas de ensaio (equivalente à capacidade resistente da zona não afetada pela introdução de cargas) os pilares e se mostraram seguros apresentando apenas fissuras em alguns ensaios. Além disso, os ensaios mostraram que as soluções utilizadas neste trabalho não diminuem a capacidade resistente do pilar misto. 
$\mathrm{Na}$ mesma linha de pesquisa, Gaiga (2008) buscou avaliar o comportamento da interface aço-concreto em pilares mistos parcialmente revestidos (Figura 2.19). Para isto, realizou simulações numéricas tridimensionais, utilizando o pacote computacional ANSYS v. 9,0 e validou os modelos numéricos com resultados experimentais disponíveis na literatura.

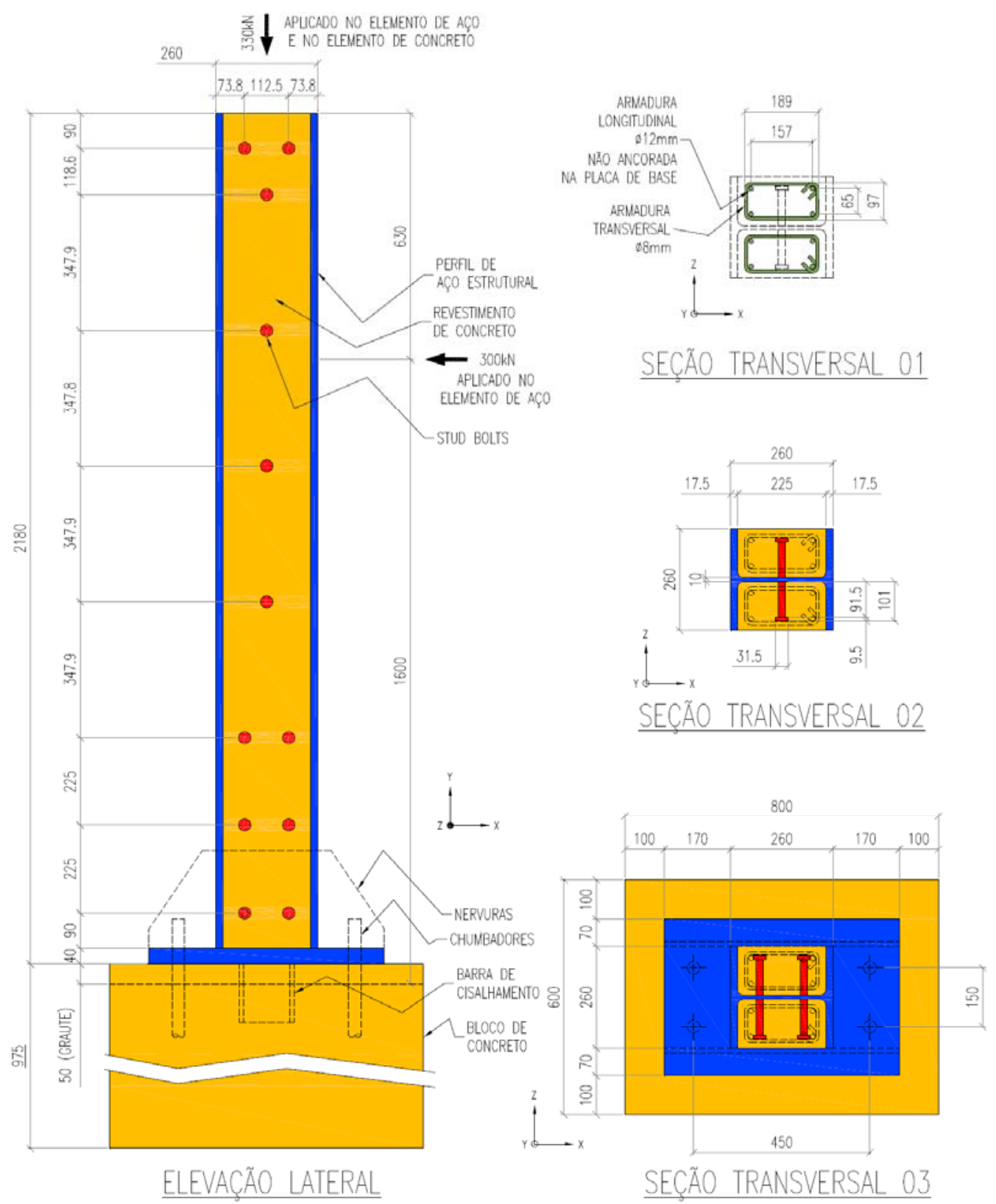

Figura 2.19 - Pilar misto parcialmente revestido estudado por Gaiga (2008)

Para simulação do perfil metálico e bloco de concreto foram utilizados elementos sólidos já para os conectores de cisalhamento utilizou-se um elemento de viga. Para a interface entre o perfil metálico e o concreto foram definidas duas superfícies: a superfície 
alvo (concreto) e a superfície de contato (perfil). Neste par de contato é possível considerar a coesão entre as partes, e o atrito (coeficiente de atrito igual a 0,3).

Nas análises realizadas, o valor máximo obtido para a tensão de cisalhamento na interface aço-concreto foi superior ao limite proposto pela norma brasileira indicando a necessidade do uso de conectores de cisalhamento. Este estudo demonstrou a importância de se entender os mecanismos de transferência de esforços das vigas e lajes para os pilares.

Já Rocha (2011) investigou a resistência ao cisalhamento na região de introdução de cargas em pilares mistos parcialmente revestidos. Foi desenvolvido estudo teóricoexperimental de modelos de pilares mistos de aço-concreto submetidos à compressão simples por meio de testes em temperatura ambiente e em altas temperaturas (situação de incêndio). Quatro configurações de seção transversal foram avaliadas: modelos sem conectores de cisalhamento e modelos com conectores de cisalhamento do tipo pino sem cabeça, com comprimento de $5 \mathrm{~cm}$ e diâmetros iguais a $12,5 \mathrm{~mm}, 16 \mathrm{~mm}$ e $19 \mathrm{~mm}$.

Nos ensaios à temperatura ambiente Rocha (2011) concluiu que a utilização de conectores de cisalhamento na região de introdução de cargas é necessária, pois contribui significativamente para o aumento da resistência na interface. Houve o desenvolvimento de fissuras nos blocos de concreto e deformações por flexão em todos os conectores de cisalhamento. Além disso, verificou-se que há um acréscimo da ductilidade do conjunto com o aumento do diâmetro do conector.

Já para os ensaios realizados a temperatura de $600^{\circ} \mathrm{C}$ houve a redução da resistência dos pinos e consequentemente da resistência ao cisalhamento, de modo que se percebeu uma redução na capacidade de carga de até 50,45\% nos protótipos com conectores de cisalhamento. Por outro lado, nos pilares sem conectores de cisalhamento esta redução foi de apenas $20 \%$. Isto pode estar associado à grande elevação da temperatura nos trechos com conectores devido a sua grande condutibilidade térmica, ocorrendo maior fissuração do concreto e assim, menor resistência do concreto.

\subsection{Considerações Finais}

Alguns aspectos são relevantes no comportamento da seção mista, como por exemplo, a flambagem local do perfil de aço. Na busca por economia de material utilizam-se chapas cada vez mais finas para compor os perfis de aço as quais estão mais sujeitas aos efeitos de instabilidade. Neste sentido, estudos mostraram que a utilização de barras transversais soldadas entre as mesas do perfil de aço aumentam a resistência à flambagem local da seção, 
conferindo maior rigidez às mesas do perfil, que passam a ter maior resistência frente à expansão lateral do concreto. Além da contenção, tais chapas contribuem para o confinamento do concreto, resultando em maior capacidade residual no trecho pós-pico e, consequentemente, pilares com maior capacidade de deformação e ductilidade. A adição de fibras de aço ao concreto também traz benefícios para a resposta estrutural e ductilidade do pilar misto parcialmente revestido.

Outro aspecto relevante são os mecanismos de aderência aço-concreto. Estes são especialmente importantes para os pilares mistos, pois o comportamento conjunto ao longo do pilar é promovido apenas pela transferência de forças de atrito sem a utilização de conectores de cisalhamento. Pesquisas avaliaram o comportamento da aderência e sua eficiência e verificou-se que o comportamento conjunto é promovido até mesmo quando o pilar misto parcialmente revestido é solicitado por carregamentos excêntricos. Além disso, investigações experimentais revelaram que a resistência à compressão do concreto tem pouca influência na aderência, entretanto o tratamento dado à superfície de contato aço-concreto, isto é, a rugosidade da superfície, tem papel determinante nas forças de aderências desenvolvidas na interface.

Atualmente, estudos do comportamento estrutural demostraram que os pilares mistos parcialmente revestidos podem ser adequados para áreas de sismos, devido à ductilidade e a capacidade de dissipação de energia observada nos ensaios com carregamentos cíclicos. Além disso, os pilares mistos em situações de incêndio possuem melhor comportamento que os pilares de aço.

Outra linha de pesquisa é o desenvolvimento de modelos numéricos simplificados que possam representar adequadamente o comportamento dos pilares mistos parcialmente revestidos. A maior dificuldade encontra-se na representação da interface aço-concreto, alguns autores utilizam elementos de interface enquanto outros buscam alternativas para evitar a discretização da interface, como por exemplo, representar o concreto por meio de molas ou com uma seção de aço equivalente.

Em suma, estudos com pilares mistos parcialmente revestidos são recentes e necessitam ser ampliados, pois há muitos questionamentos quanto ao comportamento de tais elementos estruturais. 


\section{Modelos teóricos}

\subsection{Considerações iniciais}

Este capítulo aborda o dimensionamento de pilares mistos à flexo-compressão, segundo códigos normativos. Apresenta as expressões analíticas de dimensionamento segundo a ABNT - NBR 8800:2008 e comentários sobre a metodologia utilizada pelo EUROCODE 4:2004. Além disso, apresenta expressões para estimativa das propriedades mecânicas do concreto, tais como o módulo de elasticidade, resistência à tração e energia de fraturamento do concreto.

\subsection{Norma brasileira: ABNT - NBR 8800:2008}

A ABNT - NBR 8800:2008, em seu Anexo P, trata do dimensionamento de pilares mistos. O dimensionamento é feito por um método simplificado aplicável a pilares com seções transversais total ou parcialmente revestidas com concreto e com seções preenchidas com concreto. (Figura 3.1).

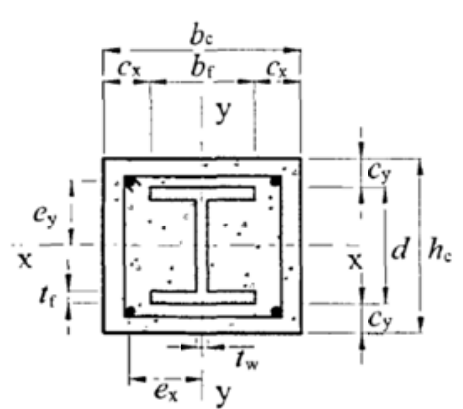

(a)

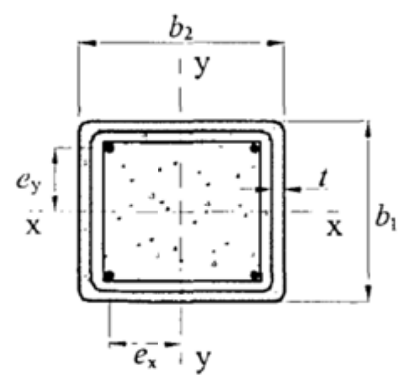

(c)

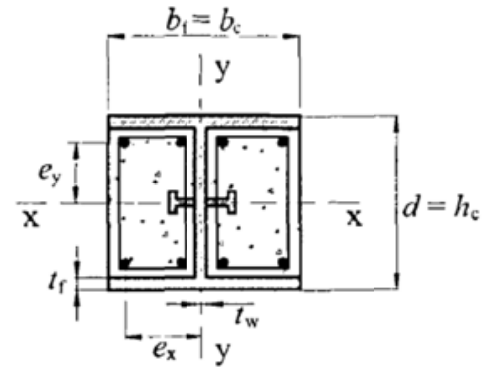

(b)

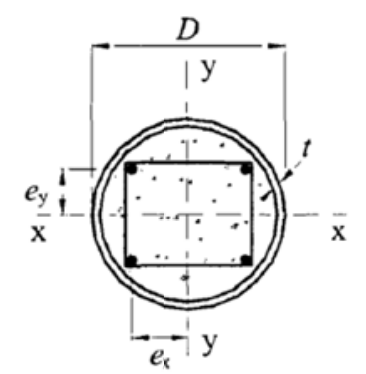

(d)

Figura 3.1 - a) seção transversal total preenchida com concreto b) seção transversal parcial revestida com concreto c) seção quadrada preenchida com concreto d) seção circular preenchiida com concreto. Fonte: 
Apenas são contemplados pela ABNT - NBR 8800:2008 perfis de aço I ou H (soldado ou laminado) ou para seções preenchidas perfis circulares ou retangulares, isto é, seções com dupla simetria. Além disso, considera-se como a hipótese básica a total interação entre o aço e o concreto, e se assume que a flambagem local não é um estado-limite último predominante.

\subsubsection{Limites de aplicabilidade}

Em seu texto a ABNT - NBR 8800:2008 traz algumas limitações de aplicabilidade do método simplificado listadas a seguir:

- Os pilares mistos devem ter dupla simetria e seção transversal constante;

- O concreto deve possuir densidade normal;

- Deve-se avaliar a contribuição do perfil metálico para a capacidade resistente da seção mista por meio do fator de contribuição do aço dado pela Equação (3.1). Este deve estar entre $0,2<\delta<0,9$. Caso $\delta$ seja igual ou inferior a 0,2 deverá ser dimensionado como pilar de concreto. Todavia se for igual ou superior a 0,9 deverá ser dimensionado como pilar de aço;

$$
\delta=\frac{A_{a} \cdot f_{y d}}{N_{p l, R d}}
$$

- As seções transversais preenchidas com concreto podem ser fabricadas sem qualquer armadura, exceto em algumas situações de incêndio. Para as seções transversais total ou parcialmente revestidas, a área da seção transversal da armadura longitudinal (As) deve estar entre: $0,3 \% \mathrm{Ac}<\mathrm{As}<4 \% \mathrm{Ac}$;

- A relação entre a altura e a largura das seções transversais mistas retangulares deve estar entre 0,2 e 5 ;

- Quando a concretagem for feita com o pilar já montado, deve-se garantir que o perfil de aço resista sozinho às ações aplicadas antes de o concreto atingir 75\% da resistência característica a compressão;

- Para as seções total ou parcialmente revestidas com concreto, deve existir armadura longitudinal e transversal para garantir a integridade do concreto. A armadura longitudinal pode ou não ser considerada na resistência e na rigidez do 
pilar misto. Nas seções parcialmente revestidas, a armadura transversal deve ser ancorada no perfil de aço através de furos da alma, ou por meio de conectores de cisalhamento.

- O projeto das armaduras deve atender aos requisitos da ABNT - NBR 6118:2007.

- Outro parâmetro que tem seu valor limitado é a esbeltez relativa do pilar, também chamado de índice de esbeltez reduzido $\left(\lambda_{0, m}\right)$, dado pela Equação (3.2), que deve ser inferior a 2,0 .

$$
\lambda_{0, m}=\sqrt{\frac{N_{p l, R}}{N_{e}}}
$$

onde, $N_{p l, R}$ e $N_{e}$ são dadas pelas Equações (3.3) e (3.4), respectivamente

$$
\begin{gathered}
N_{p l, R}=f_{y} \cdot A_{a}+\alpha \cdot f_{c k} \cdot A_{c}+f_{y s} \cdot A_{s} \\
N_{e}=\frac{\pi^{2} \cdot(E I)_{e}}{(k L)^{2}}
\end{gathered}
$$

Os efeitos de retração e fluência do concreto podem ser considerados por meio da redução do módulo de elasticidade do concreto tomando-se, no lugar de $E_{c}$, o valor de $E_{c, \text { red }}$ dado pela Equação (3.5).

$$
E_{c, \text { red }}=\frac{E_{c}}{1+\varphi\left(\frac{N_{G, S d}}{N_{S d}}\right)}
$$

onde,

Admite-se para as seções total ou parcialmente revestidas com concreto o valor de $\varphi=2,5$.

A rigidez efetiva a flexão e a compressão são dadas respectivamente pelas Equações (3.6) e (3.7). 


$$
\begin{gathered}
(E I)_{e}=E_{a} \cdot I_{a}+0,6 \cdot E_{c, \text { red }} \cdot I_{c}+E_{s} \cdot I_{s} \\
(E A)_{e}=E_{a} \cdot A_{a}+E_{c, r e d} \cdot A_{c}+E_{s} \cdot A_{s}
\end{gathered}
$$

\subsubsection{Flambagem local dos elementos de aço}

Como já delineado, a ABNT - NBR 8800:2008 não admite a utilização de perfis onde a flambagem local seja um estado-limite último predominante. Desta forma, devem-se obedecer as relações entre as dimensões do perfil metálico para garantir que todos os elementos atinjam suas resistências sem que ocorra flambagem local dos elementos.

Finalmente, para as seções formadas por perfis I ou H parcialmente revestidas com concreto, a Equação (3.8) apresenta a recomendação que devem ser respeitadas.

$$
b_{f} / t_{f} \leq 1,49 \sqrt{E / f_{y}}
$$

\subsubsection{Cisalhamento nas superfícies de contato aço e concreto}

As regiões de introdução de cargas são entendidas como regiões onde ocorrem variações localizadas dos esforços solicitantes devido à ligação entre o pilar e a viga, emendas do pilar ou em bases. Nestas regiões, as tensões de cisalhamento na interface aço/concreto, obtidas com os esforços solicitantes de cálculo $V_{l, S d}$ e $M_{l, S d}$, não devem superar os valores de $\tau_{\mathrm{Rd}}$ apresentados na Tabela 3.1.

Os valores de $V_{l, S d}$ e $M_{l, S d}$ devem ser obtidos por meio das Equações (3.9) e (3.10) para as situações onde a viga é ligada ao perfil de aço do pilar.

$$
\begin{gathered}
V_{l, S d}=V_{S d} \cdot\left(1-\frac{N_{p l, a, R d}}{N_{p l, R d}}\right) \\
M_{l, S d}=M_{S d} \cdot\left(1-\frac{M_{p l, a, R d}}{M_{p l, R d}}\right)
\end{gathered}
$$

Já quando a viga estiver ligada ao concreto do pilar deve-se obter $V_{l, S d}$ e $M_{l, S d}$ por meio das Equações (3.11) e (3.12). 


$$
\begin{aligned}
V_{l, S d} & =V_{S d} \cdot \frac{N_{p l, a, R d}}{N_{p l, R d}} \\
M_{l, S d} & =M_{S d} \cdot \frac{M_{p l, a, R d}}{M_{p l, R d}}
\end{aligned}
$$

onde, $M_{p l, a, R d}$ é a contribuição do perfil de aço para $M_{p l, R d}$ igual a $f_{y d} \cdot\left(Z_{a}-Z_{a n}\right)$

Caso essas tensões excedam os valores exibidos na Tabela 3.1, utilizam-se conectores de cisalhamento. Os conectores de cisalhamento são utilizados para garantir o fluxo de cisalhamento longitudinal entre o perfil metálico e o concreto

Tabela 3.1 - Tensão de cisalhamento resistente de cálculo $\tau_{\mathrm{Rd}}$

\begin{tabular}{cc} 
Tipo de Seção transversal do pilar misto & $\tau_{\mathbf{R d}}(\mathbf{M P a})$ \\
\hline Seção totalmente revestida com concreto & 0,30 \\
Seção tubular circular preenchida de concreto & 0,55 \\
Seção tubular retangular preenchida de concreto & 0,40 \\
Mesas de seção parcialmente revestida de concreto & 0,20 \\
Almas de seção parcialmente revestida de concreto & 0,00
\end{tabular}

Segundo a ABNT - NBR 8800:2008 nos trechos entre regiões de introdução de cargas devem ser utilizados conectores de cisalhamento se as tensões na interface ultrapassarem os valores da tensão de cisalhamento resistente de cálculo, $\tau_{\mathrm{Rd}}$, dados na Tabela 3.1. Os conectores de cisalhamento são utilizados para garantir o fluxo de cisalhamento longitudinal entre o perfil metálico e o concreto.

\subsubsection{Dimensionamento de pilares mistos parcialmente revestidos segundo a ABNT - NBR 8800:2008}

3.2.4.1 Pilares mistos parcialmente revestidos submetidos à compressão simples

Para a verificação do pilar misto devem-se conhecer as características da seção transversal, como dimensões da mesa, alma, altura total, e comprimento destravado do pilar entre contenções laterais. Nesta verificação deve-se garantir que força axial resistente de cálculo, $N_{R d}$, seja maior que a força axial solicitante de cálculo $\left(\mathrm{N}_{\mathrm{Sd}}\right)$. 
A força axial resistente de cálculo de pilares mistos pode ser calculada pela Equação (3.13).

$$
N_{R d}=\chi \cdot N_{p l, R d}
$$

A força normal resistente de cálculo à plastificação total, $N_{R d, p l}$, é a soma das forças resistentes de cálculo de cada componente do pilar misto dado pela Equação (3.14).

$$
N_{p l, R d}=N_{p l, a, R d}+N_{p l, c, R d}+N_{p l, s, R d}
$$

Onde, $N_{p l, a, R d}, N_{p l, c, R d}$ e $N_{p l, s, R d}$ podem ser estimadas pelas Equações (3.15), (3.16) e (3.17), respectivamente.

$$
\begin{gathered}
N_{p l, a, R d}=A_{a \cdot} \cdot f_{y d} \\
N_{p l, c, R d}=A_{c .} \cdot f_{c d 1}=A_{c .} \alpha f_{c d} \\
N_{p l, s, R d}=A_{s .} \cdot f_{s d}
\end{gathered}
$$

onde, $\alpha=0,85$ para pilares parcialmente revestidos.

\subsubsection{Pilares mistos parcialmente revestidos submetidos à flexo-compressão}

O dimensionamento de pilares mistos à flexo-compressão considera diagramas de interação, que simplificam a curva real de interação momento fletor-normal, cujos esforços, atuando em conjunto, levam o pilar a atingir um estado limite último. Respeitando os mesmos limites de aplicabilidade citados no item 3.2.1 os pilares submetidos à combinação de efeitos da forca axial de compressão e momento fletor, podem ser dimensionadas por meio de dois métodos de calculo: o Modelo de cálculo I e o Modelo de cálculo II.

O modelo de cálculo I trata o dimensionamento de maneira análoga ao dimensionamento de pilares de aço isolados apenas com algumas adaptações como influência do concreto entre as mesas do perfil de aço. Neste modelo a curva de interação força normal e momento fletor é composta por duas retas que delimitam sua capacidade resistente na combinação de uma força solicitante com um momento. 
Já o Modelo de calculo II a curva de interação é formada por três retas sendo que a força normal e momento fletor atuantes devem estar contidos dentro da área delimitada pela curva para que seja garantida a verificação dos esforços de flexo-compressão. A Tabela 3.2 mostra as expressões para cada um dos modelos de Cálculo.

Tabela 3.2 - Modelos de Cálculo da ABNT - NBR 8800:2008

Modelo de Cálculo I

Para $\frac{N_{S d}}{N_{R d}} \geq 0,2$

$\frac{N_{S d}}{N_{R d}}+\frac{8}{9} \cdot\left(\frac{M_{x, S d}}{M_{x, R d}}+\frac{M_{y, S d}}{M_{y, R d}}\right) \leq 1,0$

Para $\frac{N_{S d}}{N_{R d}} \leq 0,2$ :

$$
\frac{N_{S d}}{2 N_{R d}}+\left(\frac{M_{x, S d}}{M_{x, R d}}+\frac{M_{y, S d}}{M_{y, R d}}\right) \leq 1,0
$$

Onde:

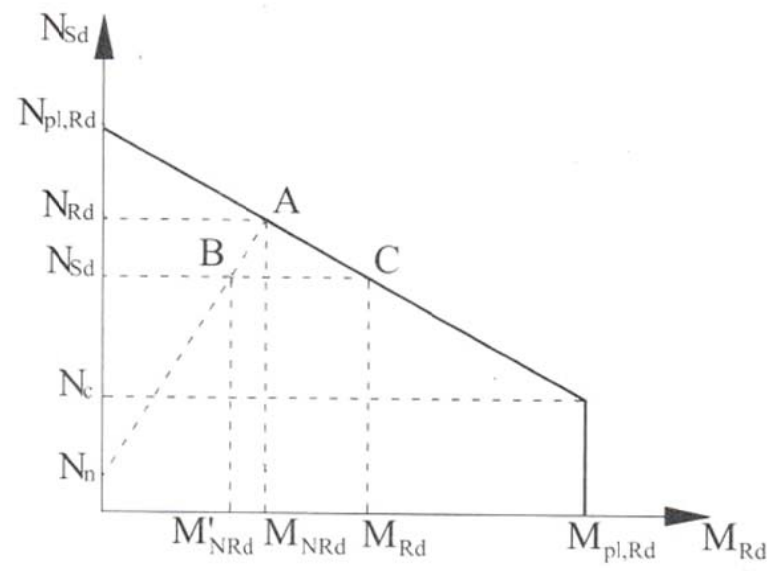

Modelo de Cálculo II

$$
\begin{gathered}
N_{S d} \leq N_{R d} \\
\frac{M_{x, t o t, S d}}{\mu_{X} M_{C, X}}+\frac{M_{y, t o t, S d}}{\mu_{y} M_{C, y}} \leq 1,0
\end{gathered}
$$

Onde,

Para $N_{S d} \geq N_{c}$

$$
\mu_{x}=1-\frac{N_{S d}-N_{p l, c, R d}}{N_{p l, R d}-N_{p l, c, R d}}
$$

$$
\begin{aligned}
& \text { Para } \frac{N_{c}}{2} \leq N_{S d} \leq N_{c} \\
& \mu_{x}=\left(1-\frac{M_{d, x}}{M_{c, x}}\right)\left(\frac{2 N_{S d}}{N_{p l, c, R d}}-1\right)+\frac{M_{d, x}}{M_{c, x}} \\
& \text { Para } 0 \leq N_{S d} \leq \frac{N_{c}}{2} \\
& \mu_{x}=1+\frac{2 N_{S d}}{N_{p l, c, R d}}\left(\frac{M_{d, x}}{M_{c, x}}-1\right)
\end{aligned}
$$

$\mu_{\mathrm{y}}$ calcula-se da mesma forma, substituindo $\mathrm{x}$ por $\mathrm{y}$.

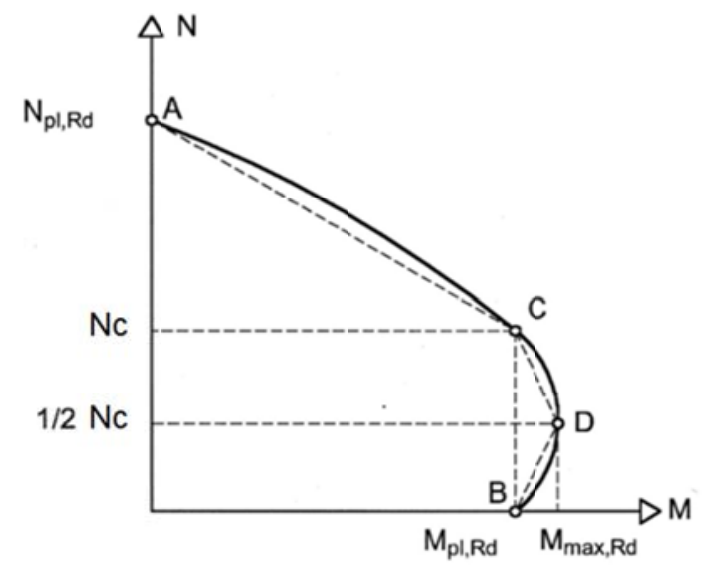

O momento de plastificação indicado na Tabela 3.2 é calculado através da Equação (3.18). 


$$
M_{p l, R d}=f_{y d}\left(Z_{a}-Z_{a n}\right)+0,5 f_{c d 1}\left(Z_{c}-Z_{c n}\right)+f_{s d}\left(Z_{s}-Z_{s n}\right)
$$

onde, $Z_{\mathrm{s}}$ é o módulo de resistência plástico da seção da armadura do concreto definido pela Equação (3.19);

$$
Z_{s}=\sum_{i=1}^{n}\left|A_{s i} \cdot e_{i}\right|
$$

onde,

$e_{i}$ é a distância do eixo da barra da armadura de área;

$A_{s i}$ é o eixo de simetria da seção.

$\mathrm{O}$ cálculo dos módulos de resistência plásticos $Z_{\mathrm{an}}, \mathrm{Z}_{\mathrm{cn}}, \mathrm{Z}_{\mathrm{sn}}$ depende da posição da linha neutra plástica e do eixo de flexão da peça. Além disso, a linha neutra é obtida a partir de um processo interativo.

A Figura 3.2 mostra uma seção I ou $\mathrm{H}$ revestida com concreto fletida em relação ao eixo $\mathrm{x}$.
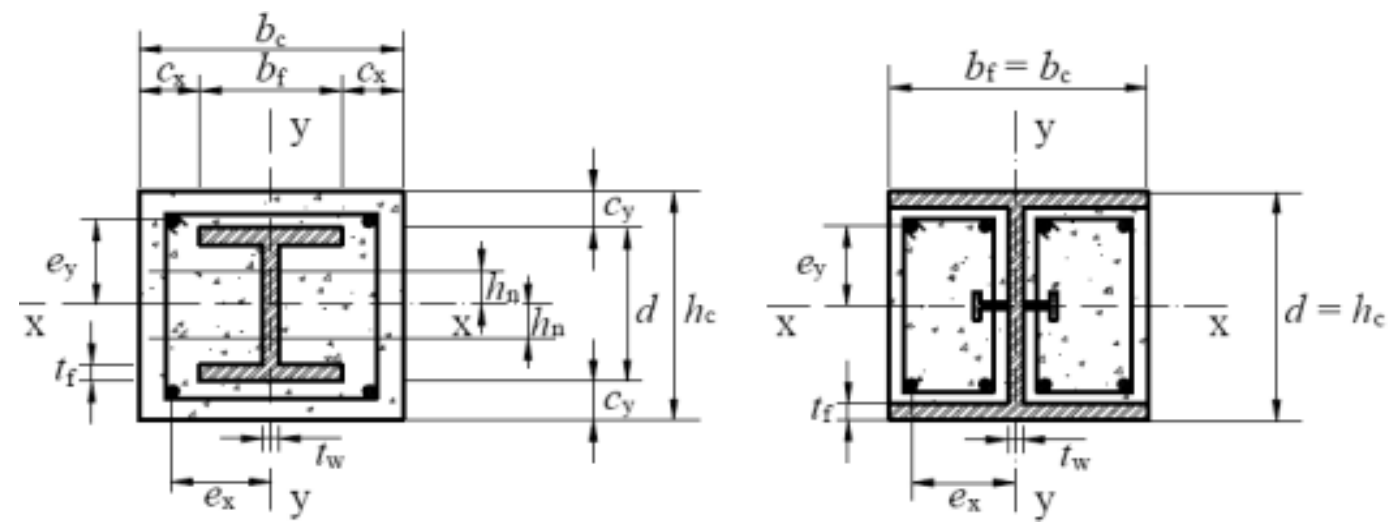

Figura 3.2 - Seção I ou H revestida com concreto fletida em relação ao eixo x. Fonte: ABNT - NBR 8800:2008

Para o eixo $\mathrm{x}$, se a posição da linha neutra plástica estiver na alma do perfil de aço dentro do intervalo de $h_{n} \leq \frac{d}{2}-t_{f}$, o cálculo da linha neutro, $\mathrm{h}_{\mathrm{n}}$, e módulos de resistência plásticos $Z_{\mathrm{an}}, Z_{\mathrm{sn}}, Z_{\mathrm{cn}}$ será dado pelas Equações (3.20), (3.21), (3.22) e (3.23), respectivamente.

$$
h_{n}=\frac{A_{c} \cdot f_{c d 1}-A_{s n} \cdot\left(2 f_{s d}-f_{c d 1}\right)}{2 b_{c} \cdot f_{c d 1}+2 t_{w} \cdot\left(2 f_{y d}-f_{c d 1}\right)}
$$




$$
\begin{gathered}
Z_{a n}=t_{w} \cdot h_{n}^{2} \\
Z_{s n}=\sum_{i=1}^{n}\left|A_{s n i} \cdot e_{y i}\right| \\
Z_{c n}=b_{c} h_{n}^{2}-Z_{a n}-Z_{s n}
\end{gathered}
$$

Entretanto, se a posição da linha neutra plástica estiver na mesa do perfil de aço dentro do intervalo de $\left.\left(\left(\frac{d}{2}-t_{f}\right)<h_{n} \leq d / 2\right)\right)$ deve-se calcular $h_{n}$ e $Z_{\text {an }}$ a pelas Equações (3.24) e (3.25). Os módulos $Z_{c n}$ e $Z_{s n}$ são calculados como já mostrado nas Equações (3.22) e (3.23).

$$
\begin{gathered}
h_{n}=\frac{A_{c} \cdot f_{c d 1}-A_{s n} \cdot\left(2 f_{s d}-f_{c d 1}\right)+\left(b_{f}-t_{w}\right)\left(d-2 t_{f}\right)\left(2 f_{y d}-f_{c d 1}\right)}{2 b_{c} \cdot f_{c d 1}+2 b_{f} \cdot\left(2 f_{y d}-f_{c d 1}\right)} \\
Z_{a n}=b_{f} h_{n}^{2}-\frac{\left(b_{f}-t_{w}\right)\left(d-2 t_{f}\right)^{2}}{4}
\end{gathered}
$$

Para os pilares parcialmente preenchidos não há o caso em que a linha neutra plástica está fora do perfil de aço.
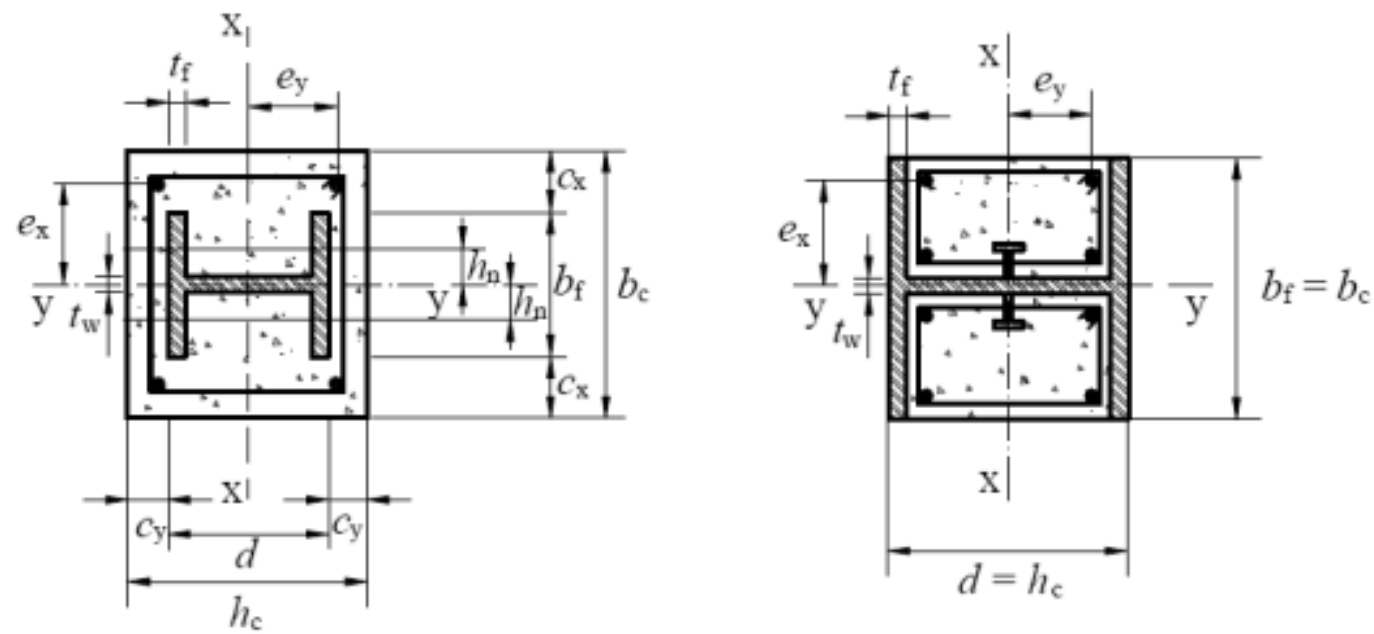

Figura 3.3 - Seção I ou H revestida com concreto fletida em relação ao eixo y. Fonte: ABNT - NBR 8800:2008

A Figura 3.3 mostra uma seção I ou H revestida com concreto fletida em relação ao eixo y. Para o eixo y se a posição da linha neutra plástica estiver na alma do perfil de aço dentro do intervalo $h_{n} \leq \frac{t_{w}}{2}$, o cálculo da linha neutro, $\mathrm{h}_{\mathrm{n}}$, e módulos de resistência plásticos $\mathrm{Z}_{\mathrm{an}}, \mathrm{Z}_{\mathrm{sn}}, \mathrm{Z}_{\mathrm{cn}}$ será dado pelas Equações (3.26), (3.27), (3.28) e (3.29), respectivamente. 


$$
\begin{gathered}
h_{n}=\frac{A_{c} \cdot f_{c d 1}-A_{s n} \cdot\left(2 f_{s d}-f_{c d 1}\right)}{2 h_{c} \cdot f_{c d 1}+2 d \cdot\left(2 f_{y d}-f_{c d 1}\right)} \\
Z_{a n}=d \cdot h_{n}^{2} \\
Z_{s n}=\sum_{i=1}^{n}\left|A_{s n i} \cdot e_{x i}\right| \\
Z_{c n}=h_{c} h_{n}^{2}-Z_{a n}-Z_{s n}
\end{gathered}
$$

Já se a posição da linha neutra plástica estiver na mesa do perfil de aço dentro do intervalo $\frac{t_{w}}{2}<h_{n} \leq \frac{b_{f}}{2}$ deve-se calcular $\mathrm{h}_{\mathrm{n}}$ e $Z_{\text {an }}$ a pelas Equações (3.30) e (3.31). Os módulos $Z_{c n}$ e $Z_{s n}$ são calculados como já mostrado nas Equações (3.22), (3.23), (3.28) e (3.29).

$$
\begin{gathered}
h_{n}=\frac{A_{c} \cdot f_{c d 1}-A_{s n} \cdot\left(2 f_{s d}-f_{c d 1}\right)+t_{w}\left(2 t_{f}-d\right)\left(2 f_{y d}-f_{c d 1}\right)}{2 h_{c} \cdot f_{c d 1}+4 t_{f} \cdot\left(2 f_{y d}-f_{c d 1}\right)} \\
Z_{a n}=2 t_{f} h_{n}^{2}+\frac{\left(d-2 t_{f}\right) t_{w}{ }^{2}}{4}
\end{gathered}
$$

Além disso, para o cálculo de pilares mistos utilizando o Modelo II da ABNT - NBR 8800:2008 é necessário conhecer os valores de $M_{c, x}$ e $M_{c, y}$ que são dados segundo as Equações (3.32) e (3.33), respectivamente.

$$
\begin{aligned}
& M_{c, x}=0,9 M_{p l, x, R d} \\
& M_{c, y}=0,9 M_{p l, y, R d}
\end{aligned}
$$

onde, $M_{p l, x, R d}$ e $M_{p l, y, R d}$ é obtido pela Equação (3.18).

Outro parâmetro importante são os valores de $M_{d, x}$ e $M_{d, y}$ que são dados segundo as Equações (3.34) e (3.35), respectivamente.

$$
\begin{aligned}
& M_{d, x}=0,8 M_{\max , p l, x, R d} \\
& M_{d, y}=0,8 M_{\max , p l, y, R d}
\end{aligned}
$$

onde, $M_{\max , p l, x \text { ou y,Rd }}$ é obtido pela Equação (3.36). 


$$
M_{\max , p l, R d}=f_{y d}\left(Z_{a}\right)+0,5 f_{c d 1}\left(Z_{c}\right)+f_{s d}\left(Z_{s}\right)
$$

Caso $M_{d, x}$ seja menor que $M_{c, x}$, então $M_{d, x}$ deve ser tomado como igual a $M_{c, x}$. O mesmo deve ser feito com $M_{d, y}$ e $M_{c, y}$.

Finalmente, os momentos fletores de cálculo totais são dadas pelas Equações (3.37) e (3.38).

$$
\begin{aligned}
& M_{x, t o t, S d}=M_{x, S d}+M_{x, i, S d} \\
& M_{y, t o t, S d}=M_{y, S d}+M_{y, i, S d}
\end{aligned}
$$

onde, $M_{x, i, S d}$ e $M_{y, i, S d}$ são os momentos devidos às imperfeições ao longo do pilar, em relação ao eixo x e ao eixo y dados pelas Equações (3.39) e (3.40), respectivamente.

$$
\begin{aligned}
M_{x, i, S d} & =\frac{N_{S d} L_{x}}{200\left(1-\frac{N_{S d}}{N_{e 2, x}}\right)} \\
M_{y, i, S d} & =\frac{N_{S d} L_{y}}{150\left(1-\frac{N_{S d}}{N_{e 2, y}}\right)}
\end{aligned}
$$

Deve-se considerar o momento devido às imperfeições ao longo do pilar em relação a apenas um dos eixos, o que proporcionar o resultado mais desfavorável.

\subsubsection{Comentário sobre as normas de dimensionamento de pilares mistos}

As normas técnicas relativas a pilares mistos parcialmente revestidos apresentam filosofias de projeto semelhantes. Comparando-se as normas técnicas ABNT - NBR 8800:2008 e EUROCODE 4:2004 observa-se que ambas apresentam métodos simplificados de dimensionamento os quais são aplicáveis apenas a seções duplamente simétricas e sem variação de seção ao longo da altura do pilar misto. Vale lembrar que o EUROCODE 4:2004 apresenta também o método geral de dimensionamento, aplicável a qualquer forma de seção 
transversal. A Tabela 3.3 sintetiza as principais limitações dos métodos simplificados apresentados pela ABNT - NBR 8800:2008 e EUROCODE 4:2004.

Uma característica comum entre as normas é a limitação da esbeltez local do perfil de aço a fim de evitar a ocorrência de flambagem local. Entretanto, a utilização de seções mais esbeltas poderia reduzir o consumo de aço e, consequentemente, o custo do pilar parcialmente revestido. Mas utilizar seções mais esbeltas implica na ocorrência de instabilidades locais que devem ser consideradas no dimensionamento. Desta forma, é necessário o estudo de seções mais esbeltas.

Tabela 3.3 - Algumas limitações normativas importantes

\begin{tabular}{ccc}
\hline Item & Norma & Prescrição \\
\hline Limite de esbeltez & EUROCODE 4:2004 & $\lambda<2,0$ \\
Instabilidade local & NBR 8800:2008 & \\
& EUROCODE 4:2004 & $b_{f} / t_{f} \leq 44 \sqrt{\frac{235}{f_{y}}}$ \\
Dimensões da seção transversal & NBR 8800:2008 & $b_{f} / t_{f} \leq 1,49 \sqrt{E / f_{y}}$ \\
& EUROCODE 4:2004 & $0,2 \leq \frac{h_{c}}{b_{c}} \leq 5,0$ \\
\hline
\end{tabular}

Nas normas de dimensionamento de pilares mistos a capacidade resistente de pilares mistos submetidos a esforços normais é estimada assumindo uma distribuição de tensões plásticas retangulares para cada um dos componentes da seção transversal.

Já o dimensionamento de pilares mistos solicitados à flexo-compressão utiliza curvas de iteração momento fletor-normal, cujos esforços, atuando em conjunto, levam o pilar a atingir um estado limite último. O Modelo de cálculo II da ABNT - NBR 8800:2008 o qual considera a curva de interação formada por três retas, é similar ao apresentado pelo EUROCODE 4:2004. 


\subsection{Estimativa das propriedades mecânicas do concreto}

\subsubsection{Módulo de elasticidade do concreto}

A ABNT - NBR 8800:2008 apresenta as Equações (3.41) e (3.42)para estimativa do módulo de elasticidade e módulo de elasticidade corrigidos devido aos efeitos de retração e fluência, respectivamente.

$$
\begin{aligned}
E c & =4760 \sqrt{f_{c k}} \\
E_{c, \text { red }} & =\frac{E c}{1+\varphi\left(\frac{N_{s d, G}}{N_{s d}}\right)}
\end{aligned}
$$

onde, $\varphi=2,5$ para pilares parcial e totalmente revestidos e $\varphi=0$ para pilares preenchidos.

Já CEB-FIB (1990) propõe que o módulo de elasticidade seja estimado segundo a equação (3.43).

$$
E_{c i}=21,5\left(f_{c k} / 10\right)^{1 / 3}(\mathrm{GPa})
$$

\subsubsection{Resistência à tração do concreto}

O valor médio da resistência à tração foi estimado pela equação (3.44).

$$
f_{c t}=1,4\left(f_{c m} / 10\right)^{2 / 3}(\mathrm{MPa})
$$

\subsubsection{Energia de fraturamento do concreto}

A energia de fratura modo I do concreto sem fibras será um parâmetro importante para descrever o comportamento do concreto na simulação numérica. $\mathrm{Na}$ ausência de dados experimentais esta pode ser estimada pela expressão do CEB-FIB (1990), definida pela equação (3.45), para concretos com resistências à compressão menor ou igual a $80 \mathrm{MPa}$. 


$$
G_{f}=G_{f o}\left(f_{c m} / f_{c m}^{0}\right)^{0,7}\left(N . m m / m m^{2}\right)
$$

sendo $f_{c m}^{0}$ igual a $10 \mathrm{MPa}$ e $G_{f o}$ estimado em função da dimensão máxima do agregado pela Tabela 3.4 .

Tabela 3.4 - Valores de $G_{f o}$ Segundo a CEB-FIP (1990)

\begin{tabular}{cc}
\hline Diâmetro do Agregado $(\mathbf{m m})$ & Energia a fratura $\boldsymbol{G}_{\boldsymbol{f o}}\left(\mathbf{N} . \mathbf{m m} / \mathbf{m m}^{\mathbf{2}}\right)$ \\
8 & 0,025 \\
16 & 0,030 \\
32 & 0,038 \\
\hline
\end{tabular}

Já a energia de fratura a tração do concreto pode ser calculada por meio das expressões propostas por Barros e Figueira (1999) representada na Equação (3.46).

$$
G_{f}^{F}=G_{f o}^{F} \cdot\left(19,935+10,506 \cdot V_{f}\right)
$$

Onde, $G_{f o}{ }^{F}$ é estimado pela Equação (3.47), válida para agregados com dimensão máxima de $9,5 \mathrm{~mm}$.

$$
G_{f o}{ }^{F}=0,0206\left(f_{c m} / 10\right)^{0,7}
$$

Já energia de fraturamento a compressão pode ser estimada, segundo Feenstra (1993), como sendo de 50 a 100 vezes o valor da energia de fraturamento à tração do concreto estudado. Entretanto análises utilizando estes valores apresentaram comportamento muito dúctil para o concreto.

Alternativamente pode-se obter a energia de fraturamento à compressão por meio da área pós-pico sob a curva tensão x deformação do concreto. Neste trabalho para a relação entre tensão e deformação do concreto foi considerada a curva proposta pelo EUROCODE 2 (2004) apresentada na Figura 3.4. 


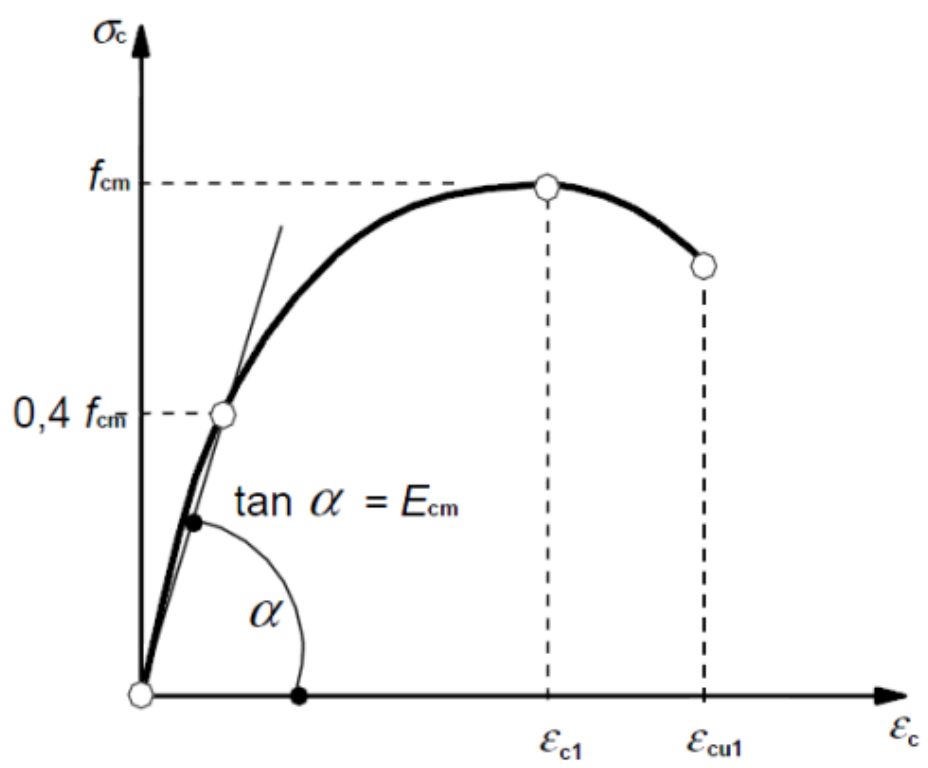

Figura 3.4 - Curva tensão-deformação do concreto considerada pelo EUROCODE 2: 2004

Este comportamento pode ser descrito pela Equação (3.48) e por meio desta equação, pode-se obter a área sob o gráfico referente à região pós-pico.

$$
\sigma_{c}=\frac{k \eta-\eta^{2}}{1+(k-2) \eta}
$$

onde,

$\eta$ é estimada pela Equação (3.49)

$$
\eta=\varepsilon_{c} / \varepsilon_{c 1}
$$

$k$ é estimado pela Equação (3.50)

$$
k=1,1 E_{c} \times\left|\varepsilon_{c 1}\right| / f_{c m}
$$

\subsection{Considerações finais}

Este capítulo serve de apoio para os capítulos que se seguem. Foram apresentadas equações analíticas para dimensionamento de pilares mistos as quais foram utilizadas para estimar a capacidade resistente dos modelos físicos ensaiados na investigação experimental e estão apresentadas no Capítulo 4. Além disso, apresenta estimativa das propriedades mecânicas do concreto utilizadas nas simulações numéricas discutidas no Capítulo 5. 
Modelos teóricos 


\section{Investigação experimental}

\subsection{Considerações iniciais}

Neste capítulo é relatada a investigação experimental acerca dos pilares mistos parcialmente revestidos realizada no âmbito deste estudo. São apresentados e descritos todos os aspectos referentes à metodologia utilizada no desenvolvimento do programa experimental referente aos pilares mistos com e sem armadura. Ademais, são fornecidos e discutidos os resultados obtidos nos ensaios, comparados a seguir com a previsão da norma ABNT - NBR 8800:2008.

\subsection{Características gerais dos modelos físicos}

Foram propostos para a investigação experimental modelos que possibilitassem avaliar a substituição da armadura convencional na forma de barras de aço por tela de aço soldada e fibras de aço descontínuas distribuídas aleatoriamente na matriz de concreto. As características gerais dos elementos ensaiados e suas quantidades são apresentadas na Tabela 4.1 .

Para cada tipo de modelo foi ensaiado um exemplar e uma réplica; isto foi feito para avaliar a variabilidade dos resultados experimentais. No estudo experimental, o exemplar com armadura convencional, aqui denominado M1, foi tomado como modelo de referência para as análises presentes no item 4.8 .

Todos os modelos foram submetidos ao ensaio de compressão axial. Cabe notar que para o modelo com adição de fibras no concreto, denominado M3, o ensaio foi realizado sob a ação de força axial centrada e força axial com excentricidade na direção do eixo de maior inércia, sendo apenas um para cada situação de carregamento (não há réplicas). O objetivo do ensaio excêntrico foi avaliar possíveis descolamentos do concreto em relação ao perfil de aço.

No tocante às armaduras dos Modelos 1 e 2, estas foram escolhidas respeitando-se o limite de armadura mínima e de modo que ambos tivessem, aproximadamente, a mesma taxa de armadura. 
Tabela 4.1 - Modelos físicos para análise experimental

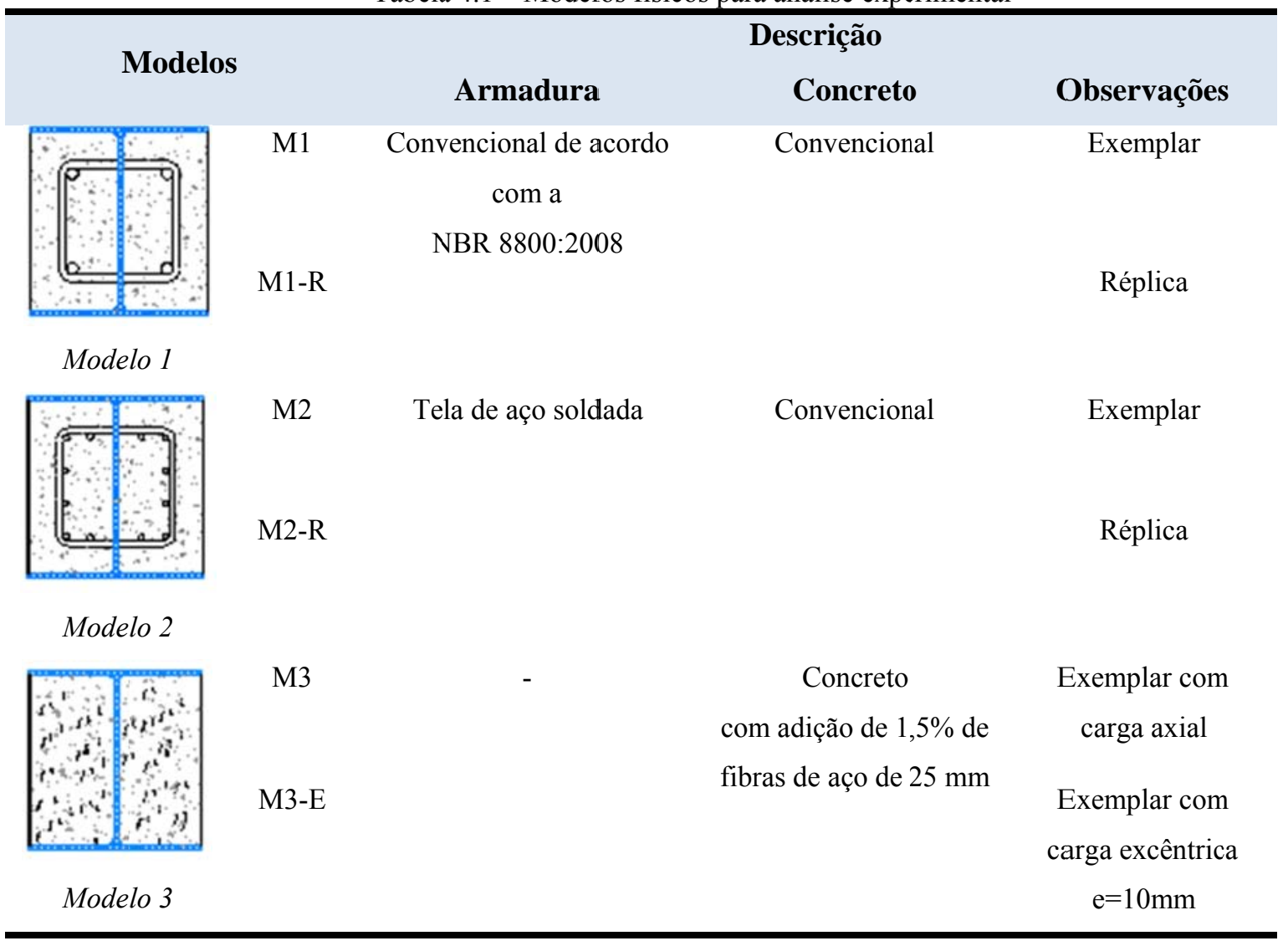

Os perfis metálicos foram obtidos a partir de chapas de aço estrutural com características semelhantes ao aço ASTM A36 de 3,18 mm de espessura soldadas com solda tipo MIG (Metal Inert Gas). Na base e no topo de cada perfil foi colocada uma chapa de aço de $12,7 \mathrm{~mm}\left(1 / 2^{\prime}\right)$ de espessura e dimensões de 171,4 x $165 \mathrm{~mm}$. O posicionamento desta chapa objetivou distribuir uniformemente os esforços na seção mista além de servir de forma.

Vale salientar que a escolha das dimensões do perfil metálico que foi norteada pela capacidade resistente da seção mista, de modo que esta fosse compatível com a capacidade da Máquina de Ensaios Universal disponível no Laboratório de Estruturas da EESC-USP. As chapas utilizadas para compor o perfil possuem a mesma espessura tanto para as mesas como a alma, apesar disto não ser a prática comum optou-se por utilizar a mesma espessura a fim facilidade e economia na produção do perfil, mas também pela importância da alma no comportamento estrutura como constado nos ensaios experimentais.

A Figura 4.1, Figura 4.2 e Figura 4.3 apresentam as características geométricas dos modelos físicos estudados experimentalmente. Vale salientar que as dimensões dos modelos foram limitadas pela capacidade nominal da máquina de ensaio universal, disponível no 
Laboratório de Estruturas da Escola de Engenharia de São Carlos, local em que os ensaios foram realizados.

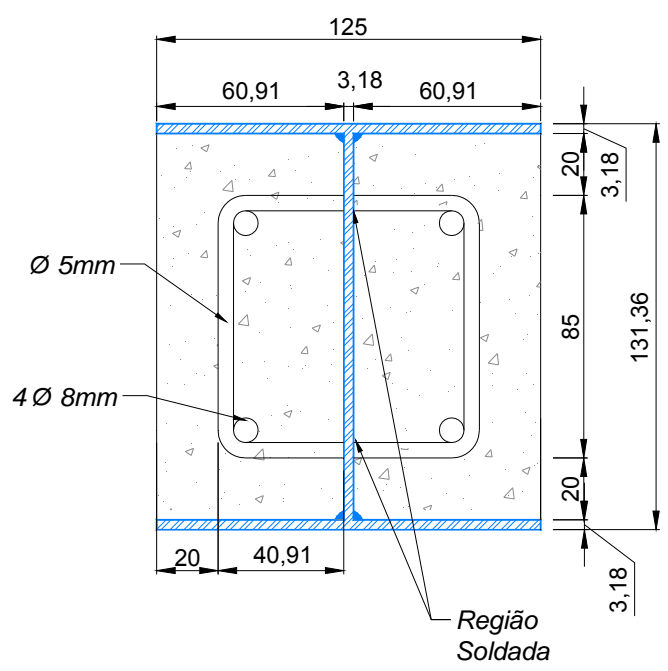

(a)

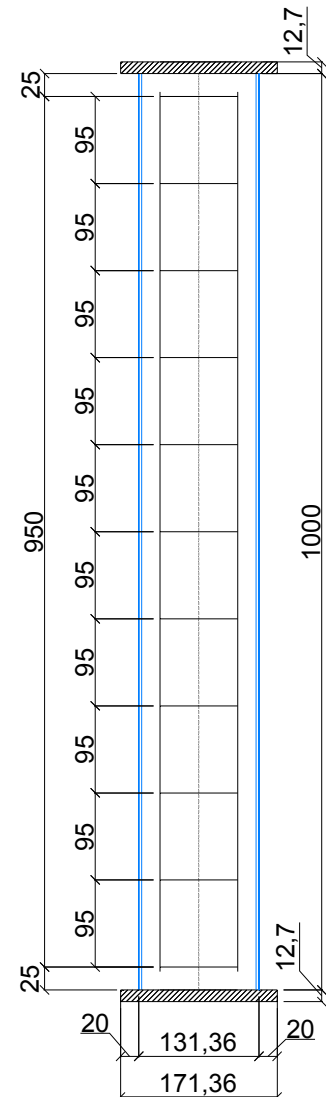

(b)

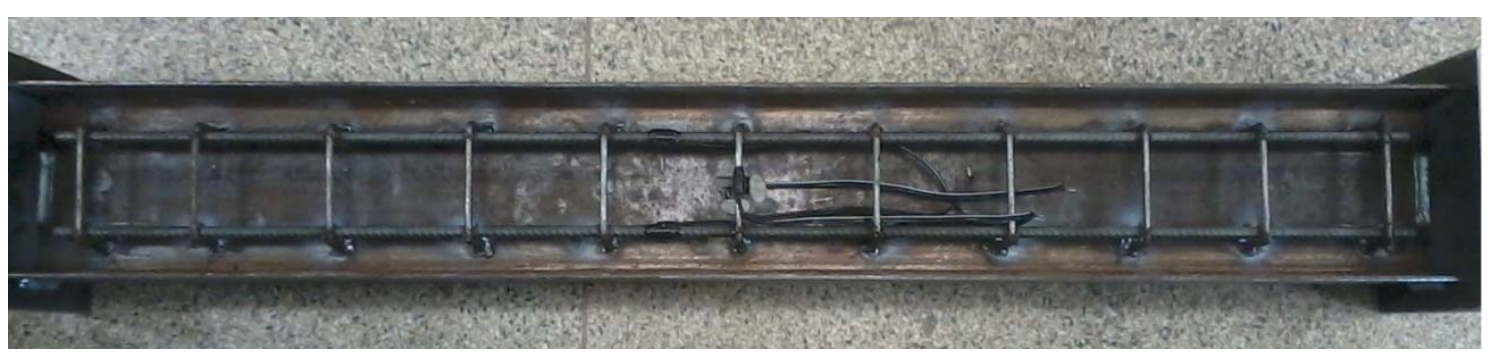

(c)

Figura 4.1 - Características geométricas do Modelo 1: (a) Seção transversal; (b) Vista lateral; (c) Ilustração 


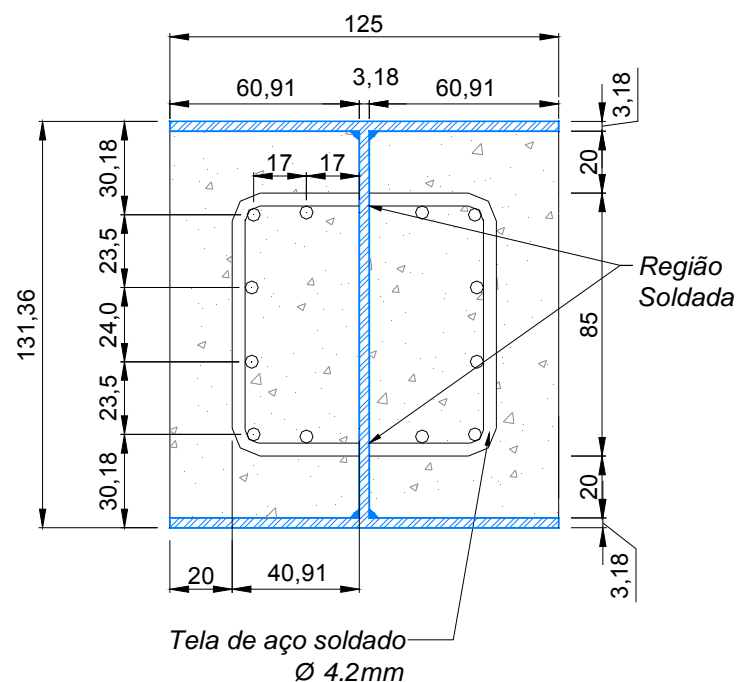

(a)

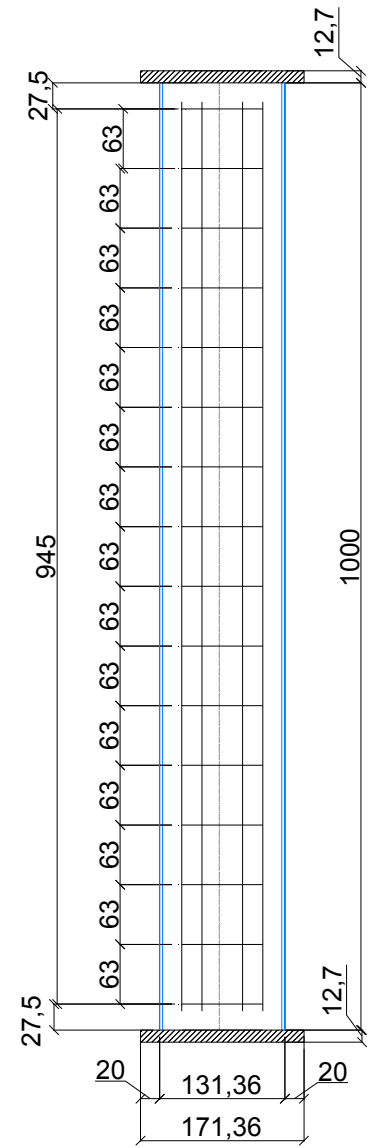

(b)

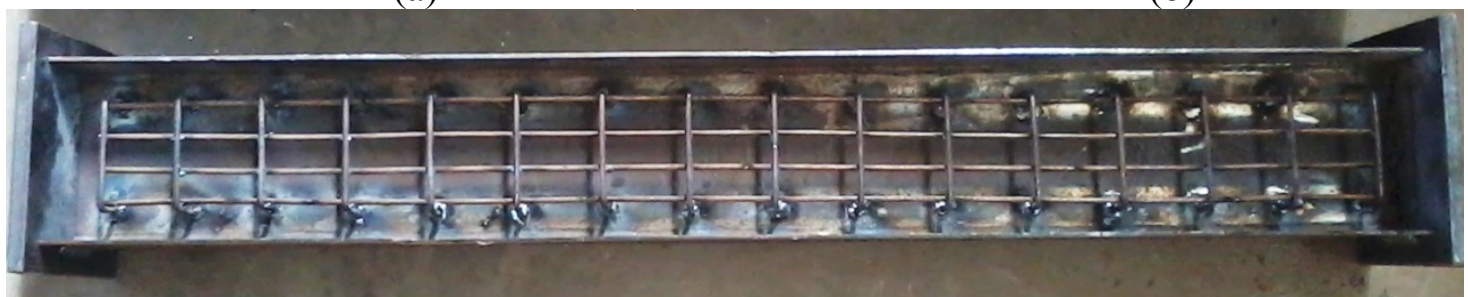

(c)

Figura 4.2 - Características geométricas do Modelo 2: (a) Seção transversal; (b) Vista lateral; (c) Ilustração 


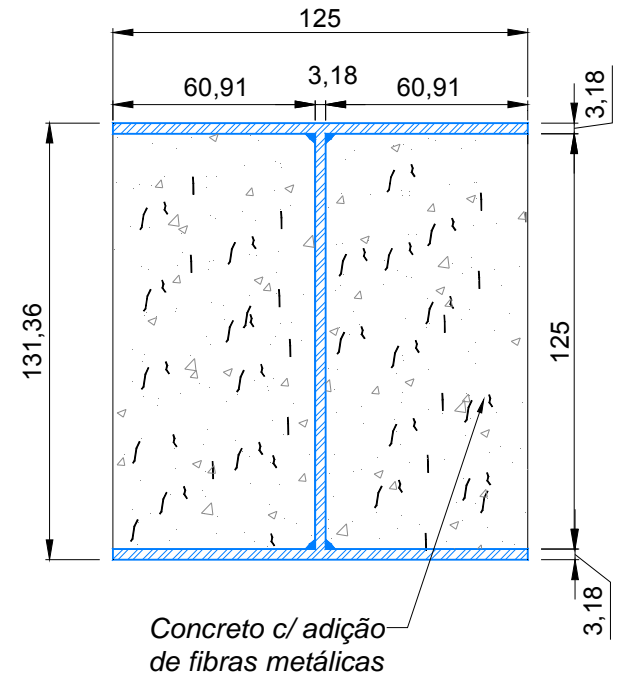

(a)

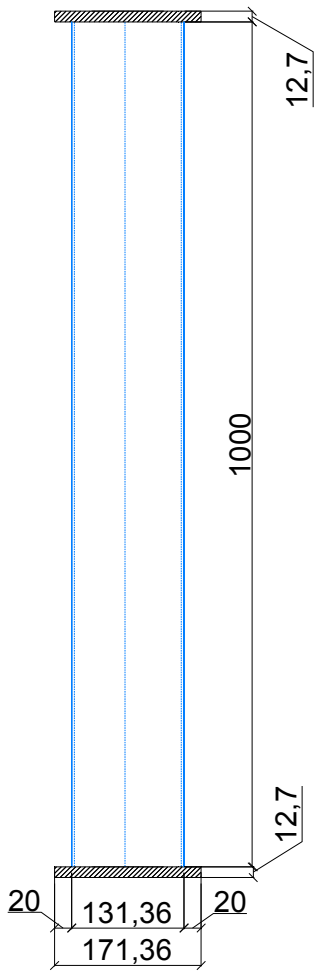

(b)

Figura 4.3 - Características geométricas do Modelo 3: (a) Seção transversal; (b) Vista lateral

\subsection{O esquema de ensaio}

O ensaio dos modelos físicos de pilares mistos foi realizado na Máquina de Ensaios Universais servo-controlada, da INSTRON Instruments, modelo 8506, com capacidade para aplicar até $2500 \mathrm{kN}$ de força na tração ou compressão. Na Figura 4.4 é apresentado o esquema de ensaio utilizado na investigação experimental dos pilares mistos.

Em relação ao esquema de carregamento, este foi feito em duas etapas: primeiro aplicou-se uma força equivalente a $30 \%$ da máxima prevista (força de escorvamento). Após a escorva, foi reiniciado o carregamento a uma velocidade de $0,005 \mathrm{~mm} / \mathrm{s}$ até atingir a força máxima resistida pelo modelo. No trecho pós-pico, a velocidade foi reduzida pela metade visando o melhor acompanhamento do trecho descendente da curva experimental do modelo. 


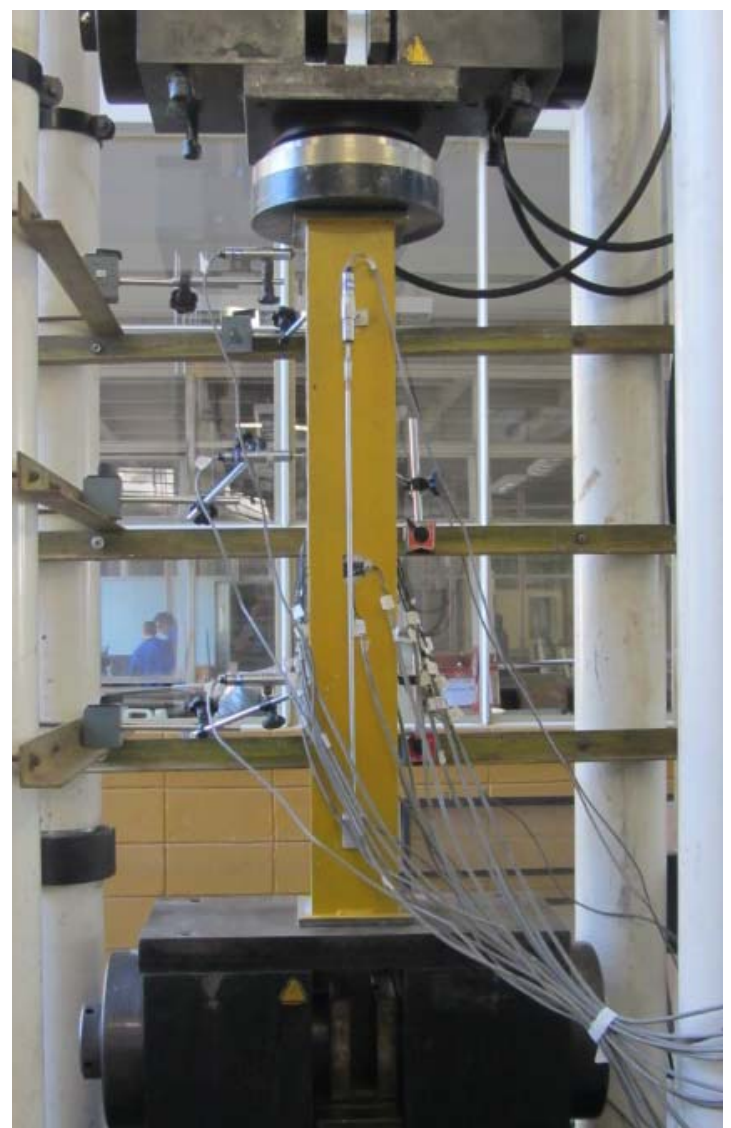

Figura 4.4 - Esquema de ensaio dos modelos de pilares mistos submetidos a força axial

Para vinculação da extremidade superior dos modelos físicos foi utilizada uma rótula, fixada na Máquina de Ensaios que permite a rotação em qualquer direção (Figura 4.5(a). Já na aplicação do carregamento excêntrico foi utilizada uma chapa na forma de meia lua, com seu centro deslocado $10 \mathrm{~mm}$ com relação ao centro do pilar, como mostra a Figura 4.5(b).

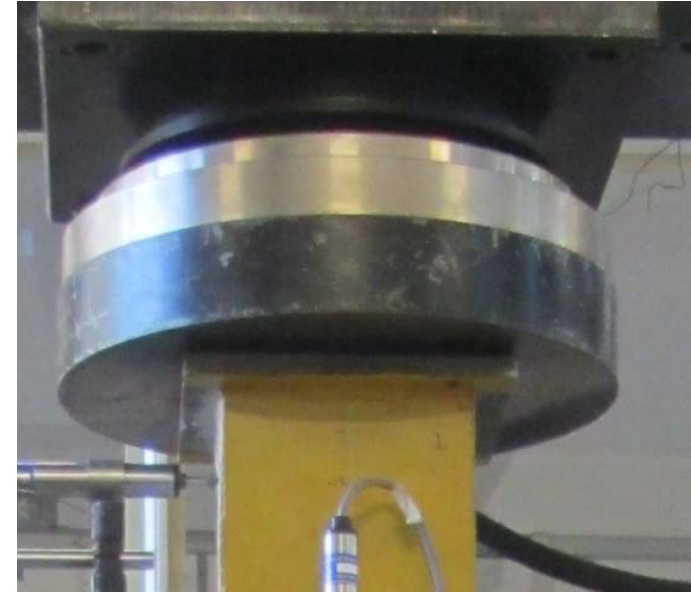

(a)

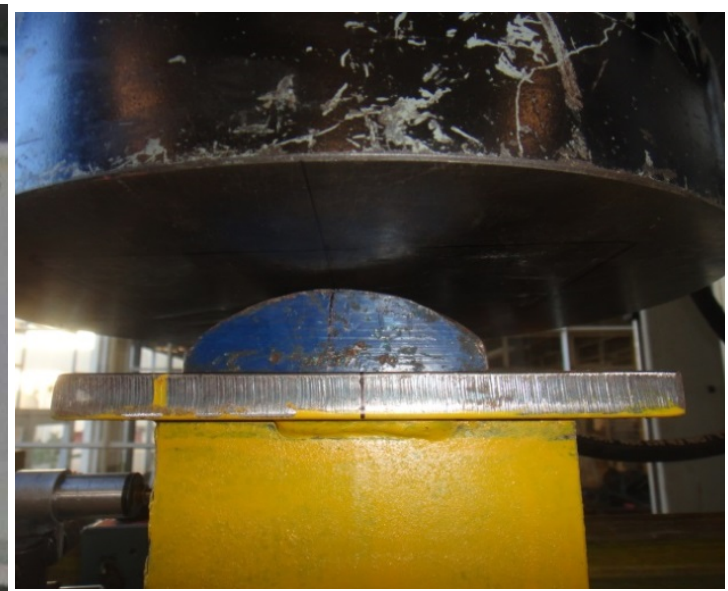

(b)

Figura 4.5 - (a) Rótula da Máquina de Ensaios; (b) Mecanismo de aplicação de carregamento excêntrico 


\subsection{Dosagem do concreto}

O revestimento do perfil metálico foi executado com concreto, convencional e com adição de fibras, cuja resistência alvo era de $50 \mathrm{MPa}$. Para isto, foi realizado um estudo de dosagem para determinação do traço mais adequado em termos de trabalhabilidade e resistência. Este estudo foi importante, sobretudo para o concreto reforçado com fibras de aço, no qual a exigência de trabalhabilidade adequada é fundamental. Em ambos, para melhorar a trabalhabilidade foi utilizado o superplastificante Glenium 51. Os traços utilizados estão indicados na Tabela 4.2.

Tabela 4.2 - Traço em massa do concreto convencional (Traço1) e com fibras (Traço 2)

\begin{tabular}{ccc}
\hline Composição & Traço 1 & Traço 2 \\
Cimento CPV-ARI & 1.00 & 1.00 \\
Areia média seca ao ar & 1.96 & 1.96 \\
Brita 0 seca ao ar & 2.24 & 2.24 \\
Fator a/c & 0.47 & 0.49 \\
Glenium 51 degussa (superplastificante) & $0.2 \%$ & $0.3 \%$ \\
Fibras aço Wirand FS8 0,75x25mm & - & $1.5 \%$ \\
Consumo de cimento $\left(\mathrm{kg} / \mathrm{m}^{3}\right.$ concreto) & & \\
\hline
\end{tabular}

A Tabela 4.3 apresenta as características geométricas e mecânicas das fibras de aço utilizadas.

Tabela 4.3 - Característica das fibras de aço

\begin{tabular}{cc}
\hline Fibras de aço & FS8 Wirand - 25 $\mathbf{~ m m}$ \\
Formato longitudinal & $0,75 \mathrm{~mm}$ \\
Diâmetro nominal & $0,4418 \mathrm{~mm}^{2}$ \\
Área da seção transversal & 33 \\
Fator de forma & $1100 \mathrm{MPa}$ \\
Tensão máxima de tração & $7850 \mathrm{~kg} / 3$ \\
Peso específico & \\
\hline
\end{tabular}




\subsection{Instrumentação dos modelos dos pilares parcialmente revestidos}

A instrumentação dos modelos físicos tem a função de permitir avaliar os valores de deslocamentos e deformações correspondentes à força aplicada pela Máquina de ensaios. A Tabela 4.4 lista os principais dispositivos de medição utilizados durante o ensaio dos pilares mistos parcialmente revestidos.

Tabela 4.4 - Equipamentos e instrumentos

\begin{tabular}{|c|c|c|c|}
\hline Equipamento & Tipo & Finalidade & Marca \\
\hline $\begin{array}{c}\text { Máquina de ensaios servo- } \\
\text { hidráulica }\end{array}$ & Modelo 8506 & $\begin{array}{c}\text { Aplicação de força de compressão } \\
\text { com controle de deslocamento do } \\
\text { atuador }\end{array}$ & INSTRON \\
\hline $\begin{array}{l}\text { Sistema de aquisição de } \\
\text { dados }\end{array}$ & System 5000 & $\begin{array}{l}\text { Coleta e gravação automática dos } \\
\text { dados }\end{array}$ & $\begin{array}{l}\text { MEASUREMENTS } \\
\text { GROUP }\end{array}$ \\
\hline $\begin{array}{l}\text { Extensômetros elétricos de } \\
\text { resistência }\end{array}$ & Biaxiais & Medir deformações & KYOWA \\
\hline $\begin{array}{l}\text { Transdutores de } \\
\text { deslocamento }\end{array}$ & - & Medir deslocamentos & KYOWA \\
\hline
\end{tabular}

\subsubsection{Registros de deformações}

A fim de registrar as deformações da seção mista e acompanhar a evolução destas com a aplicação da força de compressão, os modelos físicos foram instrumentados com extensômetros elétricos de resistência.

Foram fixados quatro extensômetros biaxiais para cada pilar misto ensaiado. A Figura 4.6 mostra a distribuição dos extensômetros utilizados para medir as deformações no aço do perfil. Cada roseta foi identificada por um par de números, por exemplo, E1-2, que indica a presença de um extensômetro na horizontal (E1) e um extensômetro na vertical (E2). 


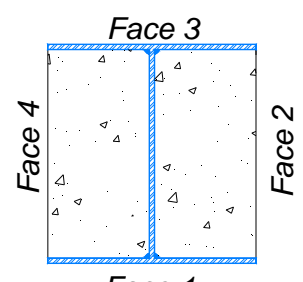

Face 1

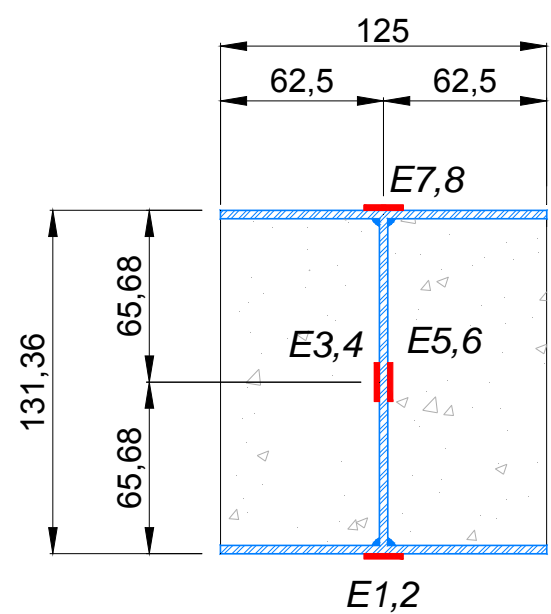

(a)

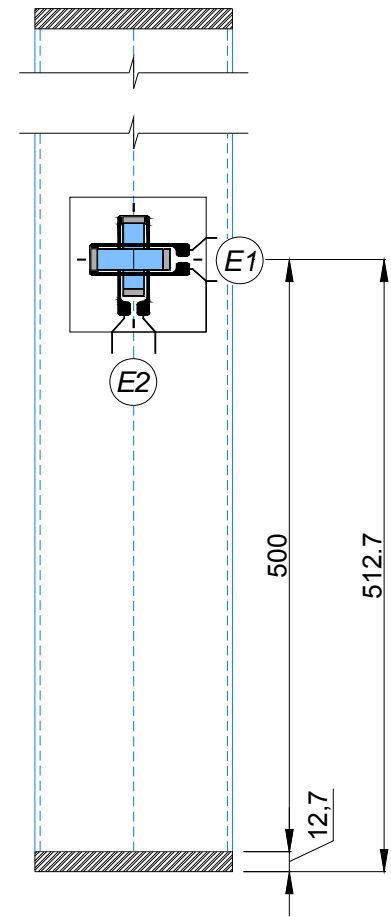

(b)

Figura 4.6 - Detalhes da Instrumentação: (a) Seção transversal; (b) Face 1

Previamente à concretagem, foram posicionados apenas os extensômetros localizados nos pontos médios das mesas do perfil de aço, localizada a $500 \mathrm{~mm}$ da base dos modelos (extensômetros 3,4,5 e 6 da Figura 4.6). No Modelo 2, que utiliza a armadura em forma de telas de aço soldadas, não foi possível posicionar estes extensômetros devido às dimensões reduzidas da tela. Desta forma, os extensômetros 3,4,5 e 6 foram posicionados, após a concretagem e preparação da superfície, na mesma localização, porém no concreto.

Para o Modelo 1, armaduras longitudinal e transversal também foram instrumentadas como indicado nas Figura 4.7 e Figura 4.8.

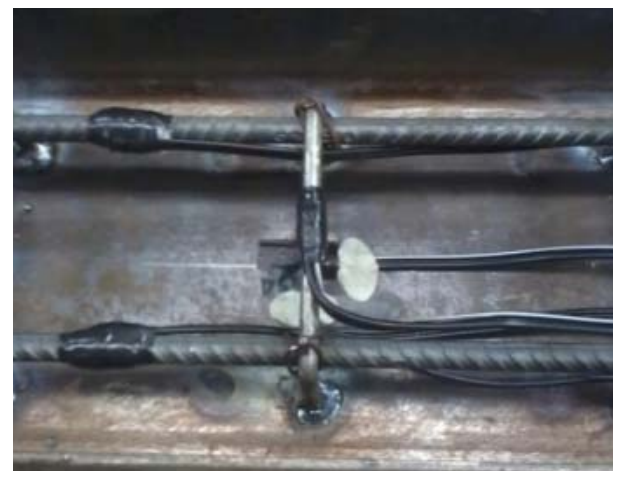

Figura 4.7 - Detalhe da instrumentação no Modelo 1 


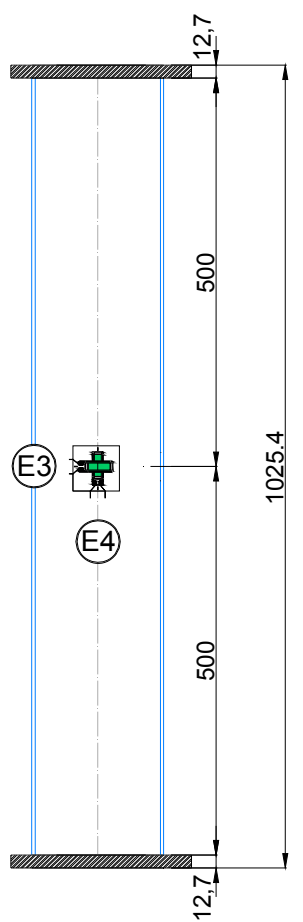

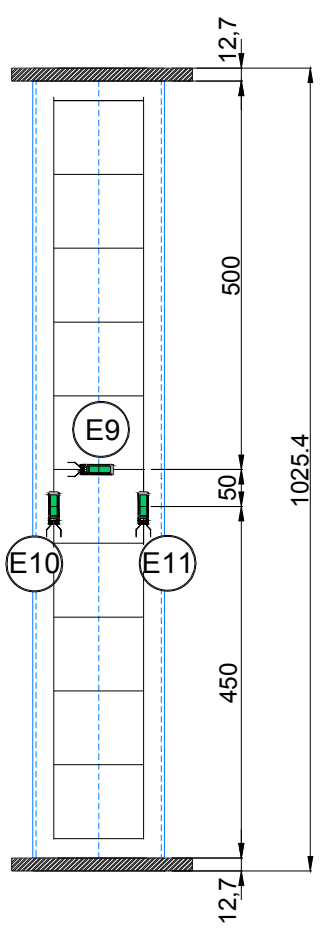

(a)

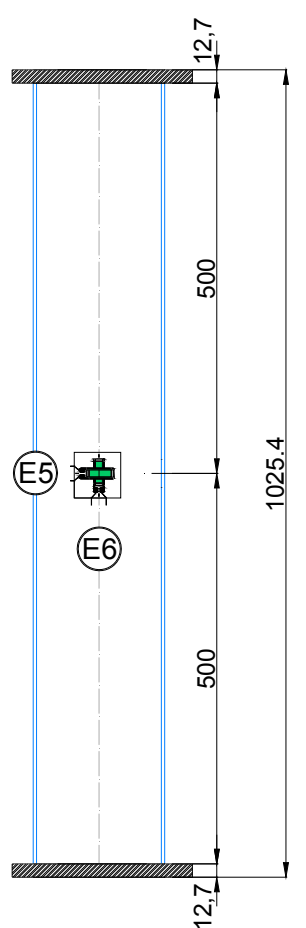

(b)

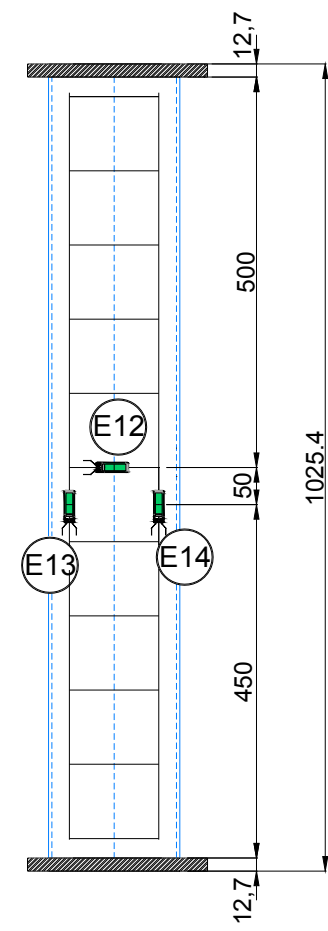$$
\text { ) }
$$

Figura 4.8 - Instrumentação Modelo 1: (a) Face 4; (b) Face 2

\subsubsection{Registros de deslocamentos}

O encurtamento do pilar foi medido por meio de um transdutor de deslocamento localizado verticalmente na face 1 (ver Figura 4.9), que captou o deslocamento relativo entre dois pontos distantes de $720 \mathrm{~mm}$. Já os deslocamentos laterais foram medidos por meio de transdutores de deslocamentos (precisão de $25 \mathrm{~mm}$ ) posicionados horizontalmente em três pontos distribuídos ao longo do comprimento do pilar em duas faces perpendiculares entre si, conforme a Figura 4.9. Estes transdutores tiveram por função verificar o aparecimento de deslocamentos transversais, os quais caracterizariam a flexão do pilar e, portanto que estaria ocorrendo uma excentricidade acidental na aplicação da força de compressão. 


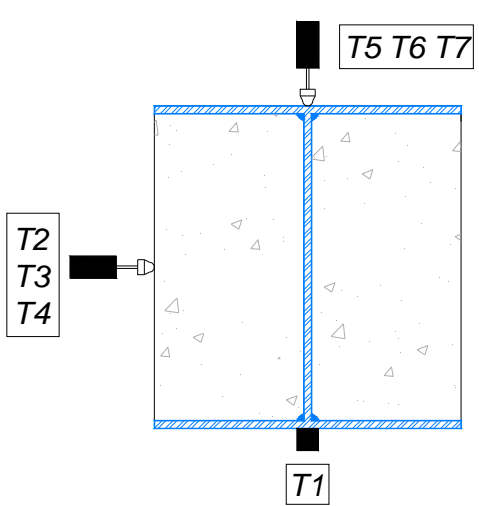

(a)

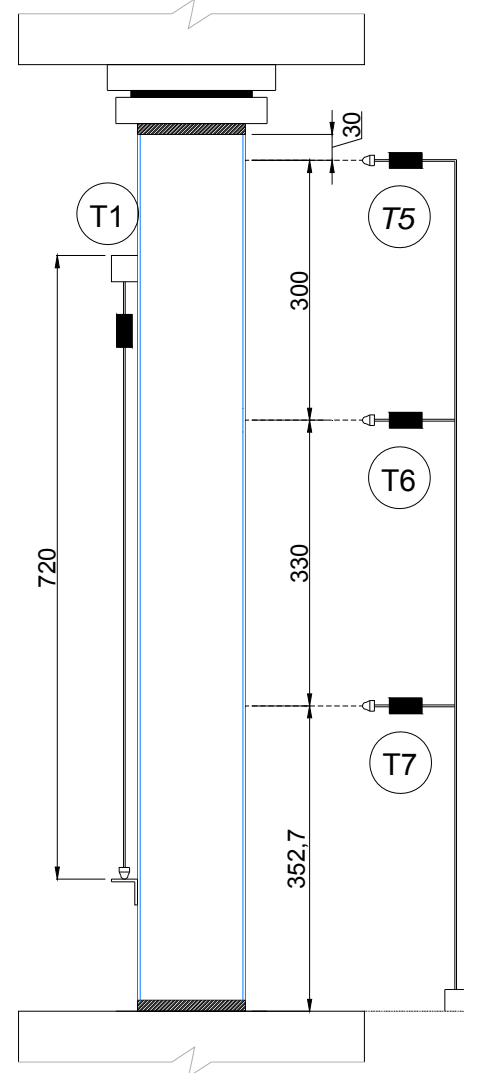

(b)

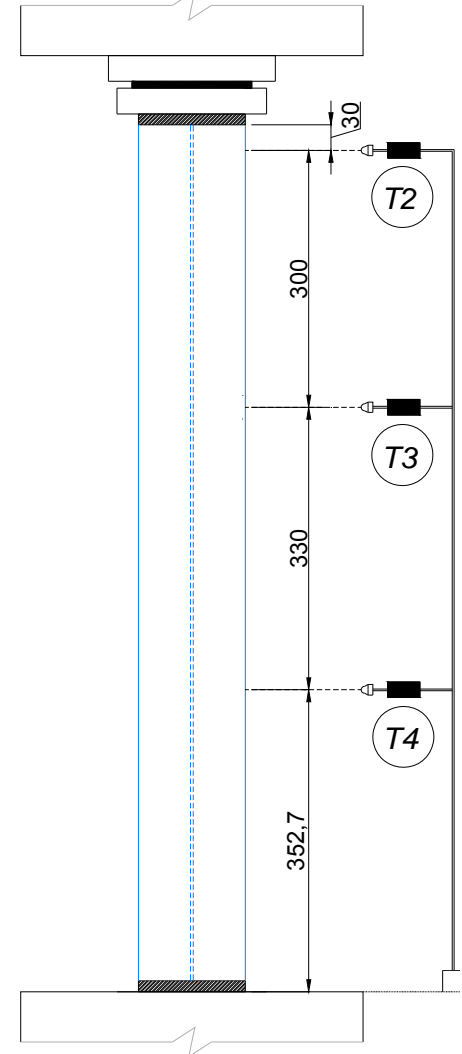

(c)

Figura 4.9 - Detalhe da instrumentação dos pilares: (a) Seção transversal; (b) Face 2; (c) Face 3

\subsection{Moldagem, adensamento e cura do concreto}

A concretagem dos pilares foi realizada em duas etapas. Inicialmente foi concretado um dos lados do pilar, e este foi submetido a um período de cura de quatro dias. Apenas após o referido período de cura do primeiro lado concretado foi realizada a concretagem do outro lado. Este procedimento de concretagem em duas etapas permitiu a eliminação de formas e uma breve avaliação de como esta etapa poderia ser feita em uma edificação.

Sucintamente as etapas de moldagem, adensamento e cura dos modelos de pilares mistos são descritas a seguir:

i. Preparação dos modelos físicos: colocação das placas de base e armaduras; colagem de extensômetros na alma do perfil metálico para os modelos do tipo M1 e M3. Vale lembrar que nos modelos M2 não houve a colagem dos extensômetros devido às pequenas dimensões da tela utilizada como armadura; 
ii. Posicionamento dos modelos na mesa vibratória. Escolheu-se este método de adensamento, pois as reduzidas dimensões do modelo dificultariam a utilização de um vibrador de imersão convencional;

iii. Concretagem e adensamento;

iv. Acabamento da superfície;

v. Moldagem dos corpos de prova.

A Figura 4.10 ilustra a etapa de concretagem e adensamento. A Figura 4.11 apresenta o aspecto final dos modelos físicos após a concretagem e pintura.
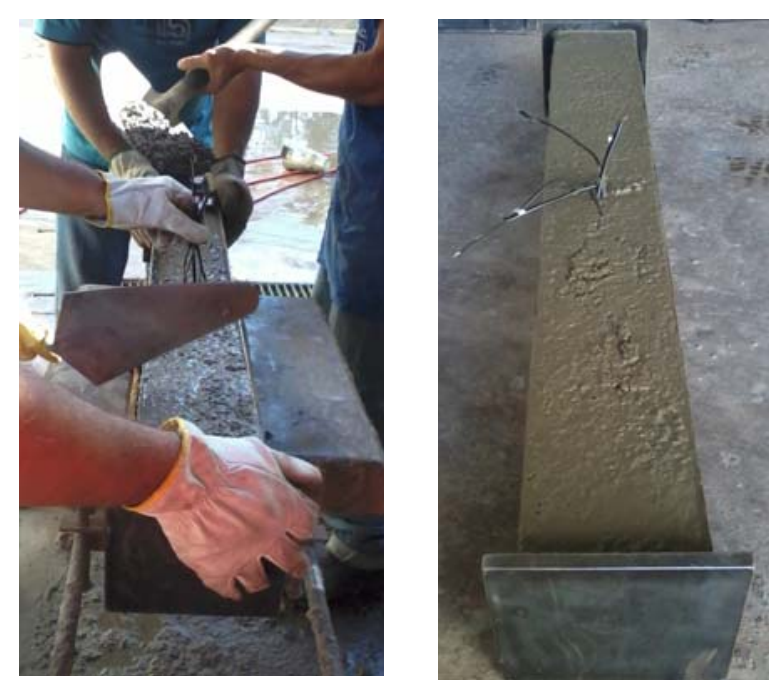

Figura 4.10 - Detalhes da concretagem

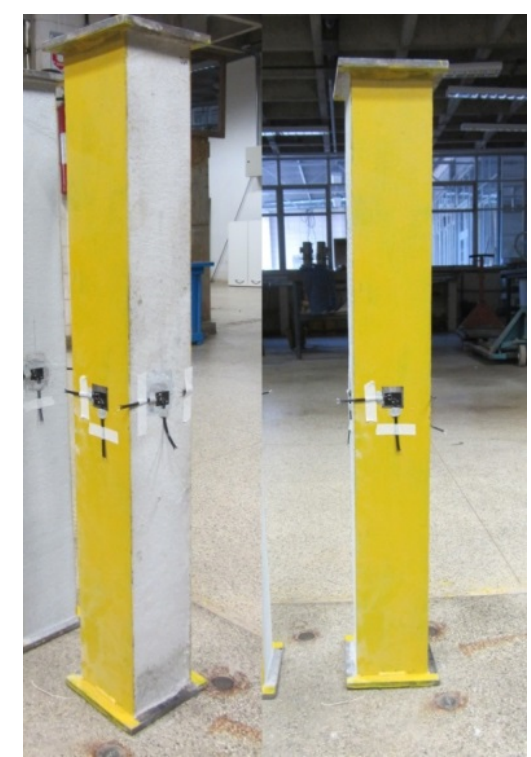

Figura 4.11 - Aspecto final dos modelos físicos 


\subsection{Caracterização dos materiais}

Neste item é descrita a metodologia utilizada para a determinação de algumas propriedades mecânicas do aço e do concreto.

\subsubsection{Concreto}

Para caracterização do concreto foram moldados, em cada dia de concretagem, dez corpos de prova cilíndricos de $(10 \times 20) \mathrm{cm}$ e cinco corpos de prova prismáticos de $(15 \times 15 \times 50) \mathrm{cm}$, os quais foram utilizados para os ensaios especificados na Tabela 4.5.

Tabela 4.5 - Caracterização do concreto de revestimento

\begin{tabular}{|c|c|c|c|}
\hline CPs & Tipo & Idade (dias) & Tipo de ensaio \\
\hline \multirow{2}{*}{6} & & & Compressão \\
\hline & Cilíndrico & & Módulos de elasticidade \\
\hline 4 & & 28 dias & Compressão diametral (tração) \\
\hline 5 & Prisma & & $\begin{array}{l}\text { Flexão sob três pontos de carga (concreto convencional) ou } \\
\text { Flexão sob quatro pontos de carga (concreto com fibras) }\end{array}$ \\
\hline
\end{tabular}

A Tabela 4.6 apresenta as propriedades mecânicas do concreto convencional e com adição de fibras obtidas a partir dos ensaios de compressão uniaxial e tração por compressão diametral para os corpos de prova cilíndricos. Ressalta-se que "Dia 1" e "Dia 2" referem-se aos dias de concretagem.

Tabela 4.6 - Valores de resistência à compressão e tração e módulo de elasticidade do concreto

\begin{tabular}{cccc} 
Concreto & \multicolumn{2}{c}{ Resistência Média } & \multicolumn{1}{c}{ Módulo de } \\
& Compressão & Tração* & Elasticidade \\
& (MPa) & (MPa) & (MPa) \\
\hline Concreto convencional - Dia 1 & 62.70 & 4.31 & 33.92 \\
Concreto convencional - Dia 2 & 46.70 & 3.66 & 31.45 \\
Concreto com fibras - Dia 1 & 53.20 & 5.57 & 33.73 \\
Concreto com fibras - Dia 2 & 41.00 & 4.08 & 27.54 \\
\hline
\end{tabular}

\footnotetext{
*por compressão diametral
} 
Como pode ser observado, houve certa variação entre as resistências médias obtidas em cada dia de concretagem. Estas variações podem estar relacionadas com as mudanças de temperatura ambiente durante os dias de concretagem ou a troca da marca do cimento, devido a problemas com o fornecedor, ainda que ambos fossem do tipo CPV-ARI.

A Figura 4.12 ilustra o aspecto dos corpos de prova após o ensaio de resistência a compressão. Pode-se constatar que as fibras impedem o estilhaçamento do corpo de prova.

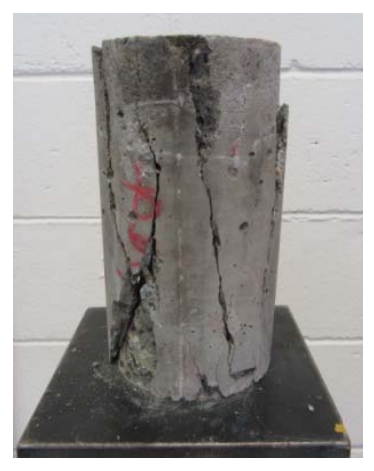

(a)

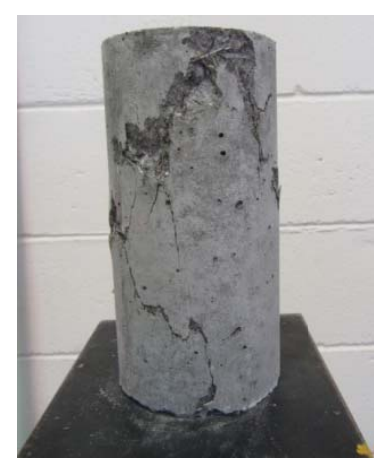

(b)

Figura 4.12 - Caracterização corpos de prova cilíndricos: (a) Concreto convencional; (b) Concreto com fibras.

No que diz respeito os corpos de prova prismáticos de concreto convencional, estes foram submetidos a ensaios de flexão por três pontos, a fim de determinar a energia de fraturamento do modo I do concreto convencional. Buscando evitar a dissipação de energia fora da zona de fratura, os corpos de prova foram entalhados no meio do vão até uma altura de $30 \mathrm{~mm}$ conforme (Figura 4.13).
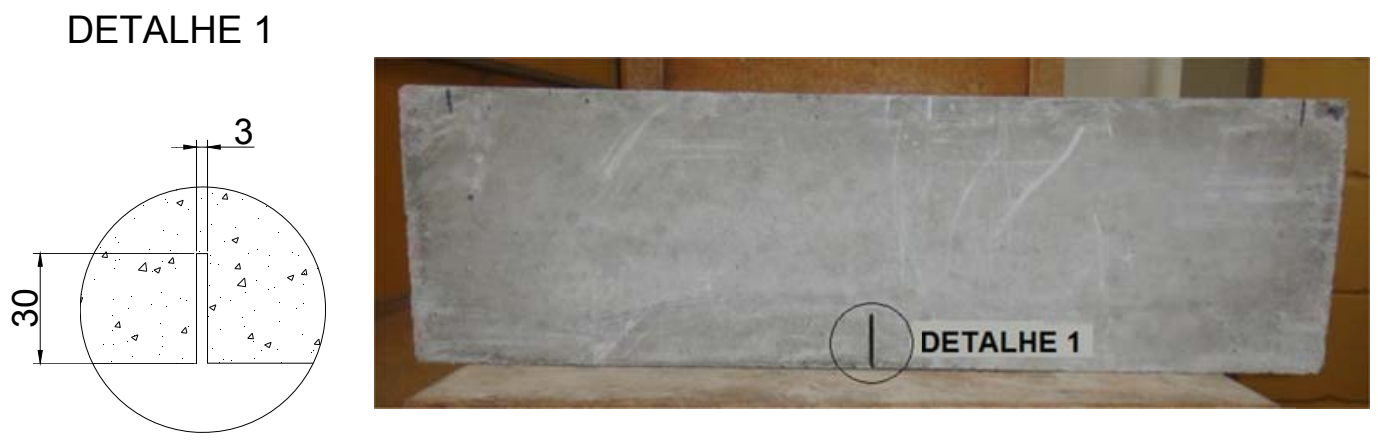

Figura 4.13 - Detalhe do entalhe no corpo de prova (Unidades em mm) 
Estes ensaios foram executados na Máquina de Ensaios Universal com capacidade de $1500 \mathrm{kN}$ e a velocidade de carregamento adotada foi de $0,0005 \mathrm{~mm} / \mathrm{s}$, com controle de deslocamento do atuador, estabelecido pela abertura do entalhe, medida por um "clip-gage". O deslocamento no meio do vão foi medido por transdutor de deslocamento resistivo com precisão de $25 \mathrm{~mm}$. O esquema de ensaio é apresentado na Figura 4.14.
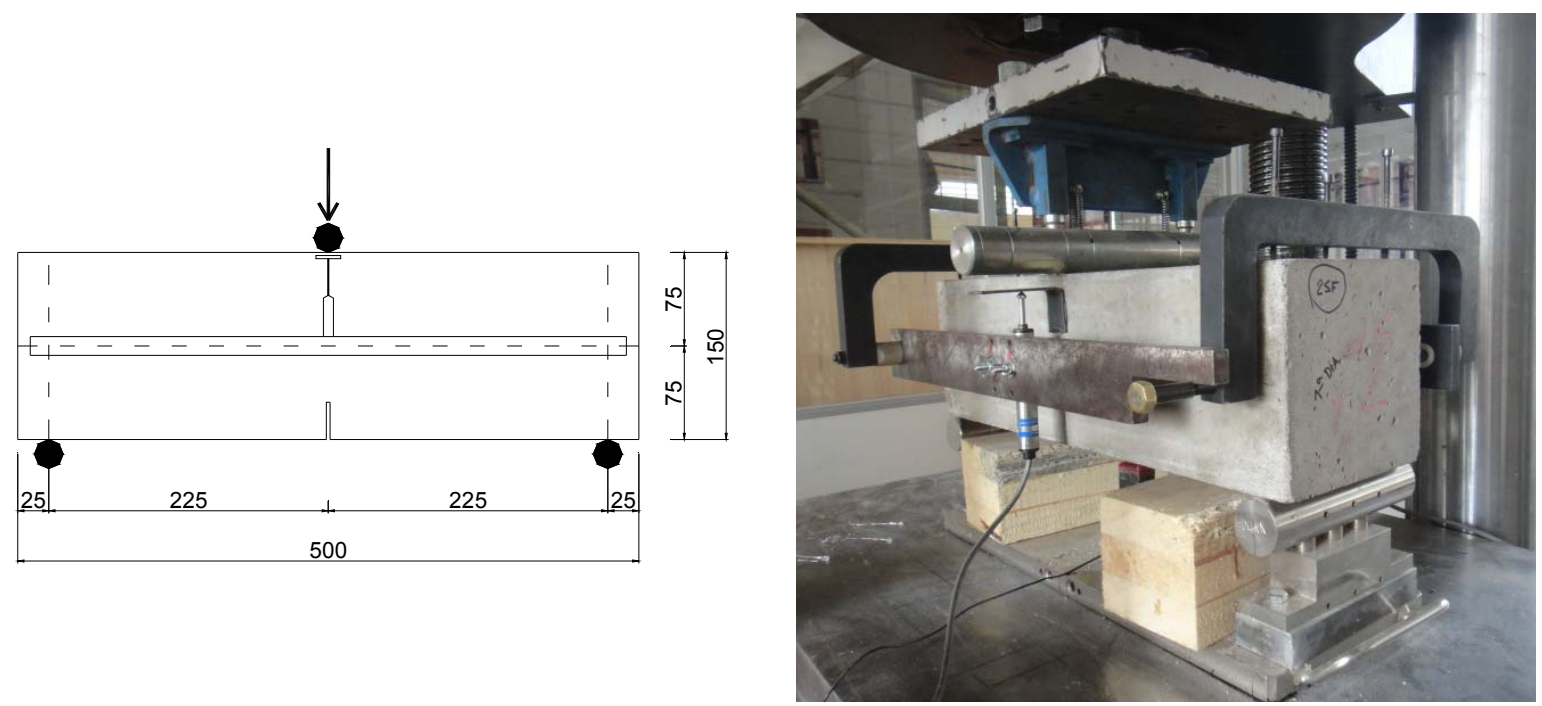

Figura 4.14 - Esquema de Ensaio de flexão sob três pontos de carga (Unidades em mm)

Segundo as recomendações da RILEM 50-FCM (1985) a energia de fraturamento $\left(G_{f}\right)$ pode ser calculada por meio da Equação (4.1).

$$
G_{f}=\frac{W_{0}+\left(m_{1}+m_{2}\right) g \delta_{0}}{A_{l i g}}
$$

onde,

$\mathrm{m}_{1}$ é a massa do corpo-de-prova entre apoios, calculada como a massa do corpo-deprova multiplicada por $\ell / L$; $\ell$ é o vão teórico do corpo-de-prova; $m_{2}$ é a massa do equipamento que acompanha a deformação do corpo-de-prova durante o ensaio e que não está acoplada ao atuador; g é a aceleração da gravidade.

A Tabela 4.7 apresenta os resultados obtidos por meio deste ensaio. 
Tabela 4.7 - Energia de fraturamento para o concreto convencional

\begin{tabular}{|c|c|c|c|c|}
\hline & $\mathbf{C P}$ & $\begin{array}{l}\text { Flecha } \\
\text { última }\end{array}$ & $\begin{array}{c}\text { Energia de } \\
\text { Fratura }\end{array}$ & $\begin{array}{c}\text { Energia de } \\
\text { Fratura média }\end{array}$ \\
\hline & & $\begin{array}{c}\delta_{0} \\
(\mathrm{~m})\end{array}$ & $\begin{array}{c}\text { Gf } \\
(\mathrm{N} / \mathrm{m})\end{array}$ & $\begin{array}{c}\text { Gf,med } \\
(\mathrm{N} / \mathrm{m})\end{array}$ \\
\hline \multicolumn{5}{|c|}{ Concreto convencional } \\
\hline \multirow[t]{4}{*}{ Dia 1} & 2 & 0,001005 & 161,62 & \\
\hline & 3 & 0,001441 & 160,84 & \\
\hline & 4 & 0,002809 & 190,13 & \\
\hline & 5 & 0,000708 & 176,32 & 172,23 \\
\hline \multicolumn{5}{|c|}{ Concreto convencional } \\
\hline \multirow[t]{4}{*}{ Dia 2} & 7 & 0,001010 & 181,85 & \\
\hline & 8 & 0,001300 & 154,03 & \\
\hline & 9 & 0,001740 & 194,14 & \\
\hline & 10 & 0,001310 & 175,14 & 176,29 \\
\hline
\end{tabular}

Vale salientar que a realização de ensaio de flexão em três pontos de carga com entalhe no meio do vão superestima a energia de fraturamento do concreto com adição de fibras, pois ocorre a múltipla fissuração e, portanto a área fissurada é maior que a área acima do entalhe. Desta maneira, este ensaio foi realizado apenas para o concreto convencional.

Não obstante, para a determinação do índice de tenacidade do material, foi realizado o ensaio de flexão por quatro pontos, nos CPs prismáticos restantes (concreto com adição de fibras). É bem verdade, que o objetivo real desses ensaios é determinar de forma indireta a energia de fraturamento do concreto com adição de fibras.

Segundo Araújo, Carmo e Prado (2007) é possível obter a curva tensão vs. deformação à tração do concreto com adição de fibras por meio de uma análise inversa do ensaio de flexão sob quatro pontos de carga utilizando um software de elementos finitos, e consequentemente a energia de fraturamento. Este procedimento é descrito no Capítulo 5.

Os ensaios de tenacidade foram realizados na máquina de ensaio universal, INSTRON, com capacidade de $2500 \mathrm{kN}$ e a velocidade de carregamento adotada foi de 0,005 $\mathrm{mm} / \mathrm{min}$. O deslocamento no meio do vão foi medido por um transdutor de deslocamento e a distância entre apoios era de $450 \mathrm{~mm}$. 

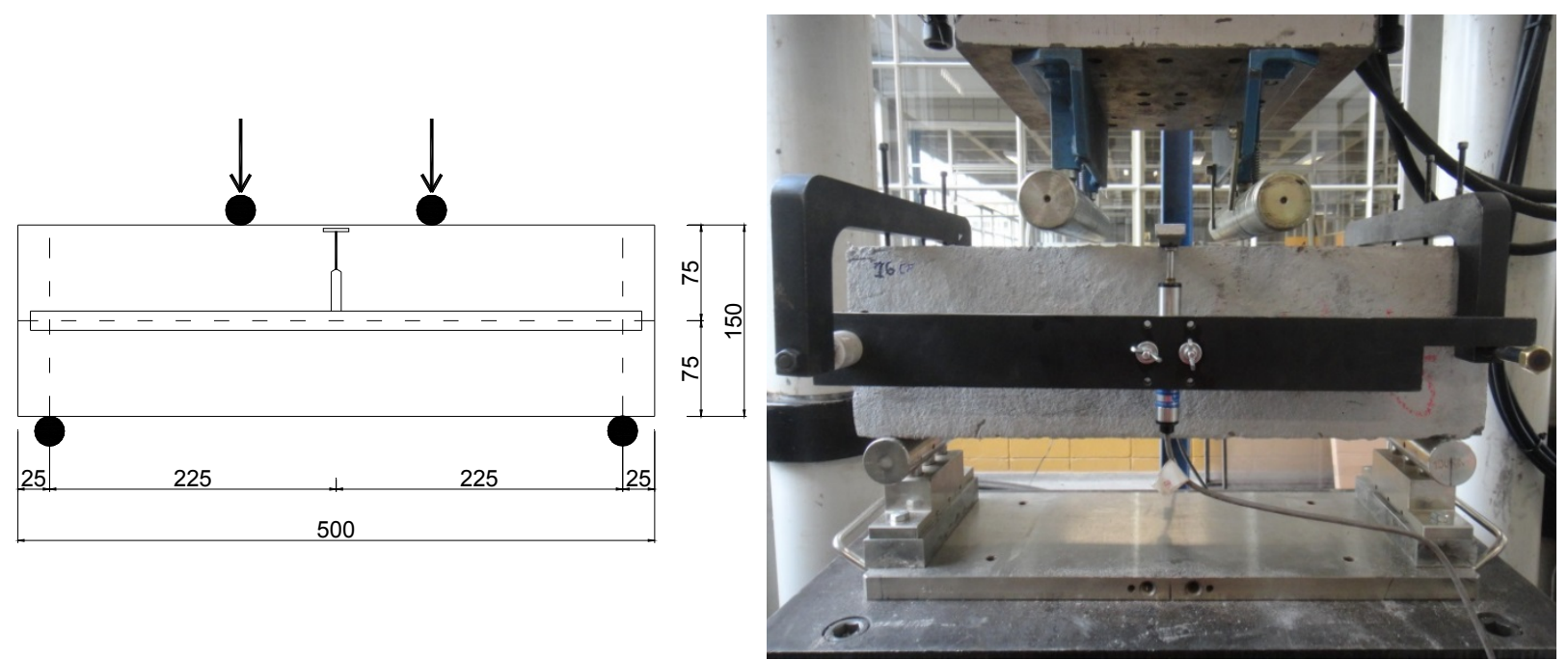

Figura 4.15 - Esquema de ensaio de flexão sob quatro pontos de carga (Unidades em mm)

\subsubsection{Barras de aço da armadura}

A caracterização das barras de aço utilizadas nas armaduras convencionais foi feita com amostras de $100 \mathrm{~cm}$ de comprimento utilizadas para a determinação da resistência ao escoamento e módulo de elasticidade. Os ensaios de tração foram realizados na máquina de ensaios universal disponível no laboratório utilizando as recomendações da ABNT - NBR 6892-1:2013. As propriedades mecânicas obtidas estão apresentadas na Tabela 4.8.

\begin{tabular}{ccccc} 
Tabela 4.8 & \multicolumn{3}{c}{ Propriedades mecânicas barras de aço - diâmetro de 5mm } \\
\hline $\mathbf{C P}$ & \multicolumn{2}{c}{$\emptyset_{\boldsymbol{b}}=\mathbf{5 0} \mathbf{~ \mathbf { m }}$} & \multicolumn{2}{c}{$\emptyset_{\boldsymbol{b}}=\mathbf{8 0} \mathbf{~ m m}$} \\
& $\mathbf{E}$ & $\boldsymbol{\sigma}_{\boldsymbol{y}}$ & $\mathbf{E}$ & $\boldsymbol{\sigma}_{\boldsymbol{y}}$ \\
& $\mathbf{( G P a )}$ & $\mathbf{( M P a )}$ & $\mathbf{( G P a )}$ & $\mathbf{( M P a )}$ \\
\hline C1 & 186,05 & 679,01 & 194,38 & 557,44 \\
C2 & 201,26 & 663,50 & 215,12 & 565,16 \\
C3 & 197,23 & 680,44 & 206,70 & 585,38 \\
Média & 194,85 & 674,31 & 205,40 & 569,33 \\
\hline
\end{tabular}

As barras que compõem a tela de aço soldado não puderam ser ensaiadas na máquina disponível do laboratório devido às dimensões reduzidas de sua seção transversal. 


\subsubsection{Aço do perfil}

Conforme as especificações da ASTM A370-97a, foram realizados ensaios para caracterização mecânica do aço do perfil metálico. Foram retiradas três amostras cujas dimensões são apresentadas na Figura 4.16.

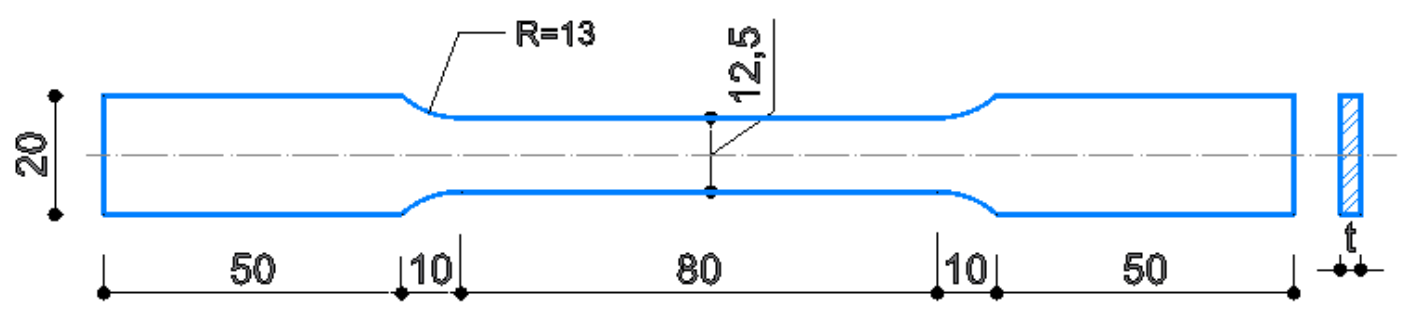

Figura 4.16 - Dimensões do corpo-de-prova para caracterização do aço

Os corpos de prova foram ensaiados à tração axial numa Máquina de ensaios e instrumentados com um extensômetro removível (Figura 4.17). Obteve se deste ensaio a curva força vs. deslocamento a partir da qual foi possível obter a resistência ao escoamento e resistência ultima do aço do perfil. A Tabela 4.9 apresenta as propriedades mecânicas do aço do perfil.

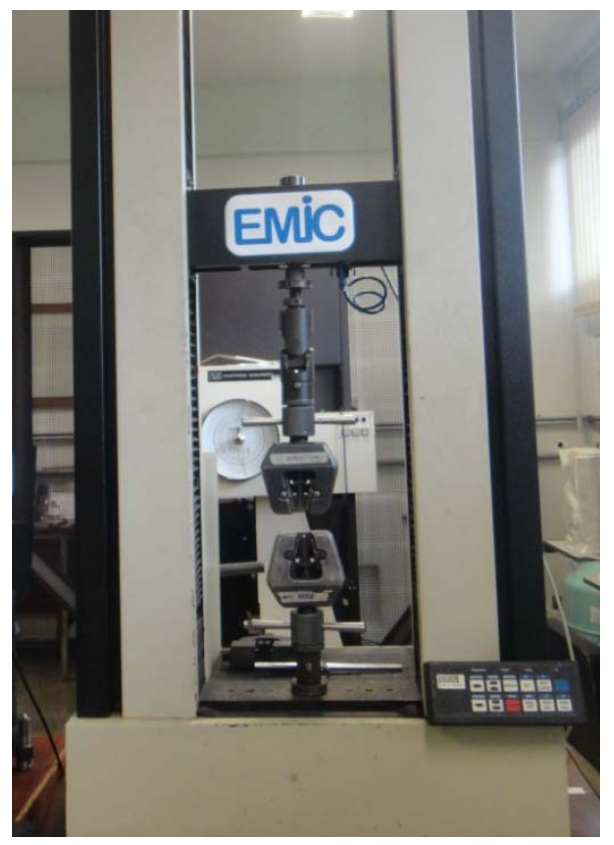

(a)

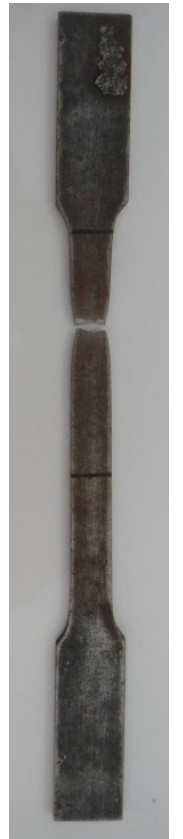

(b)

Figura 4.17 - (a) Máquina de Ensaios; (b) Corpo de prova ensaiado 
Tabela 4.9 - Propriedades Mecânicas do aço do perfil

\begin{tabular}{cccc}
\hline Amostra & $\begin{array}{c}\text { Módulo de } \\
\text { elasticidade } \\
\text { (GPa) }\end{array}$ & $\begin{array}{c}\text { Resistência ao } \\
\text { escoamento } \\
\text { (MPa) }\end{array}$ & Resistência última \\
\hline 1 & 271,05 & 326,30 & (MPa) \\
\hline 2 & 210,21 & 322,10 & 416,30 \\
3 & 197,83 & 320,30 & 412,20 \\
Média & 226,36 & 322,90 & 411,30 \\
\hline
\end{tabular}

\subsection{Pilares parcialmente revestidos: resultados e discussão}

Os resultados obtidos nos ensaios dos seis modelos de pilares mistos foram agrupados em função dos registros de deformação e deslocamento como segue. Finalmente é apresentada a configuração final dos modelos após a realização do ensaio.

A Tabela 4.10 apresenta os valores de força última obtida experimentalmente para os seis pilares mistos ensaiados. Os resultados serão discutidos a seguir.

\begin{tabular}{ccc} 
Tabela 4.10 - Capacidade resistente experimental do \\
\cline { 2 - 3 } Modelo & $\mathbf{F}_{\text {exp }}$ \\
\hline Modelo 1 & M1 & 943,00 \\
& M1-R & 974,00 \\
Modelo 2 & M2 & 954,00 \\
& M2-R & 950,00 \\
Modelo 3 & M3 & 961,00 \\
& M3-E & 816,00 \\
\hline
\end{tabular}

\subsubsection{Deslocamentos}

Por meio de curvas Força aplicada vs. Encurtamento vertical é possível avaliar comportamento global dos pilares mistos. Essas curvas foram plotadas para todos os modelos físicos ensaiados.

Ao avaliar as curvas plotadas no gráfico da Figura 4.18 para os modelos M1 e M1-R observa-se que estes apresentam comportamento similar em termos de rigidez e capacidade 
resistente. A força aplicada máxima, a qual corresponde a capacidade resistente do elemento misto foi de $943,00 \mathrm{kN}$ para o modelo $\mathrm{M} 1$ e de $974,00 \mathrm{kN}$ para o modelo M1-R. A divergência entre os valores é de apenas $3,28 \%$.

Nota-se um comportamento bastante dúctil para o elemento misto em análise, em especial para o modelo M1, com grande capacidade de deformações plásticas no pós-pico. Estes fatores demonstram boa correlação entre o exemplar e a réplica, indicando pouca variabilidade dos dados e assim maior confiabilidade dos resultados apesar do número pequeno de modelos físicos ensaiados.

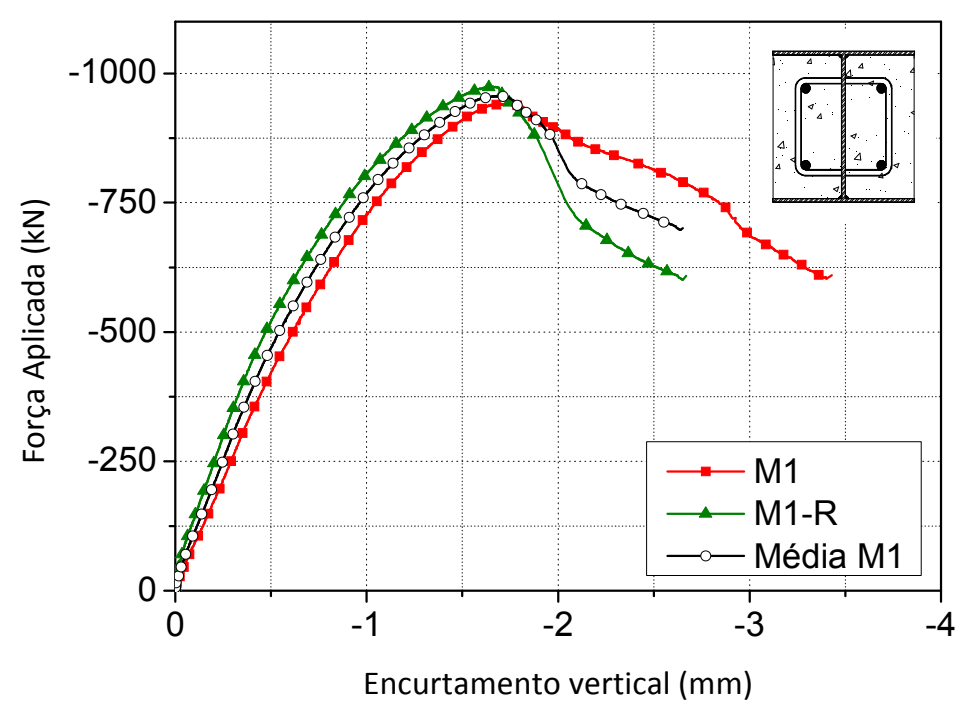

Figura 4.18 - Curva Força Aplicada vs. Encurtamento vertical para os modelos M1 e M1-R

Além das curvas para os modelos M1 e M1-R foi plotada a curva Força aplicada vs. Encurtamento vertical média, que corresponde à média aritmética dos valores de força e deslocamento obtidos nos ensaios para os modelos M1 e M1-R. Esta curva foi utilizada para representar o comportamento de pilares mistos com as configurações do modelo 1 (com armadura convencional) e serviu como curva de referência para as comparações com os demais modelos.

Para todos os pilares ensaiados, foi observado, devido ao deslizamento da extremidade superior do pilar um deslocamento lateral, de modo que a restrição lateral conferida pela rótula superior da máquina de ensaio não foi totalmente eficiente, permitindo algum deslocamento. Os gráficos da Figura 4.19 apresentam os deslocamentos laterais registrados na face 4 do modelo M1-R. Fica claro que ocorreram deslocamentos na extremidade superior do 
pilar e o eixo do pilar, representado pela linha preta, gira em sentido horário com o aumento da força aplicada.

Este deslocamento da extremidade foi corrigido nos gráficos apresentados na Figura 4.20. Manteve-se o eixo do pilar sempre na mesma posição para uma melhor visualização da evolução da configuração deformada de flexão, com o aumento da força aplicada.

Os deslocamentos laterais registrados pelos transdutores de deslocamento posicionados em faces perpendiculares entre si com esta correção são apresentados na Figura 4.20. O comportamento dos deslocamentos laterais observados para o Modelo M1 e M1-R foram similares, mas os valores registrados para o modelo M1 foram ainda menores o que dificultaria a visualização no gráfico; desta forma a título de ilustração são apresentadas apenas as curvas obtidas para o modelo M1-R.

Tais gráficos permitem avaliar a evolução dos deslocamentos laterais com o aumento da força aplicada e assim, visualizar de modo aproximado a configuração final dos modelos físicos.

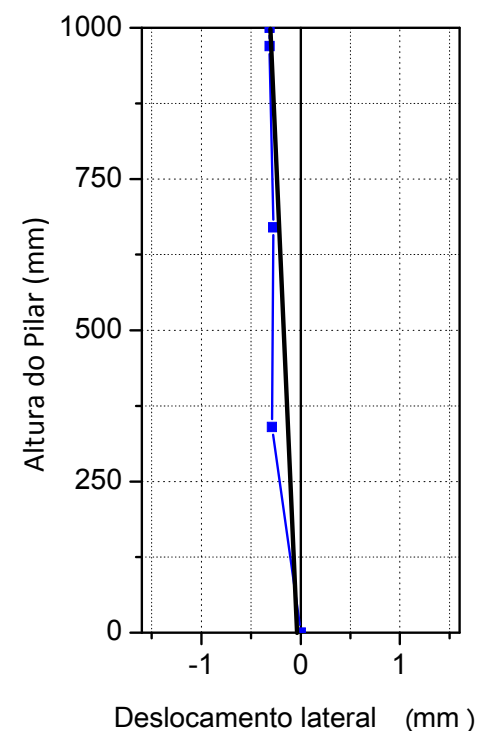

(a)

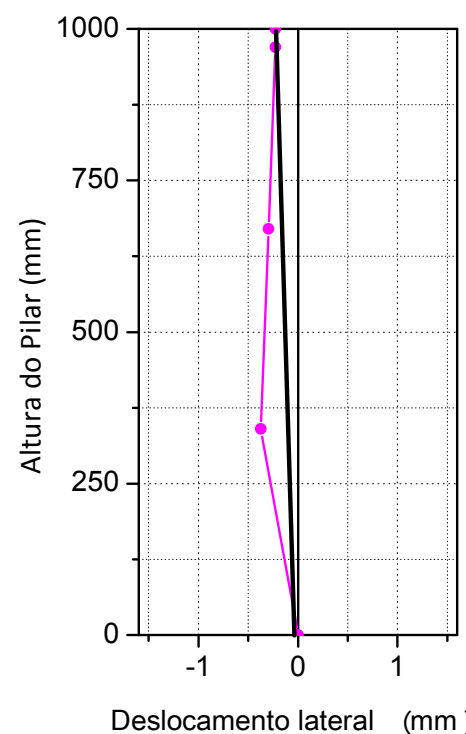

(b)

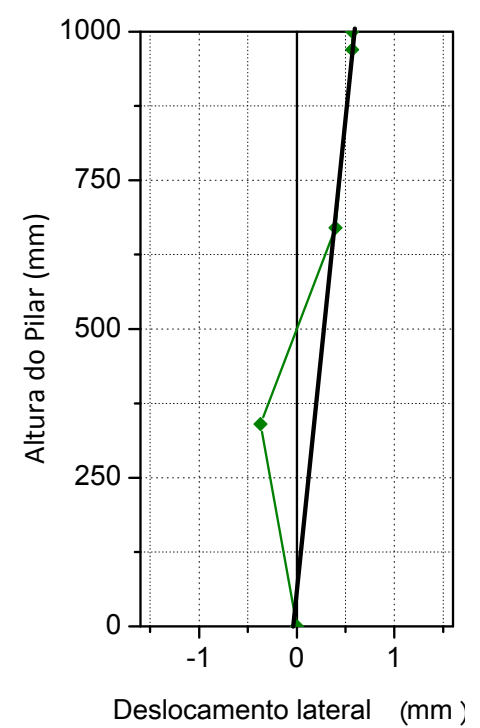

(c)

Figura 4.19 - Deslocamentos para o modelo M1-R: (a) 200 kN; (b) 600 kN; (c) 900 kN 


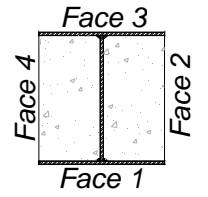

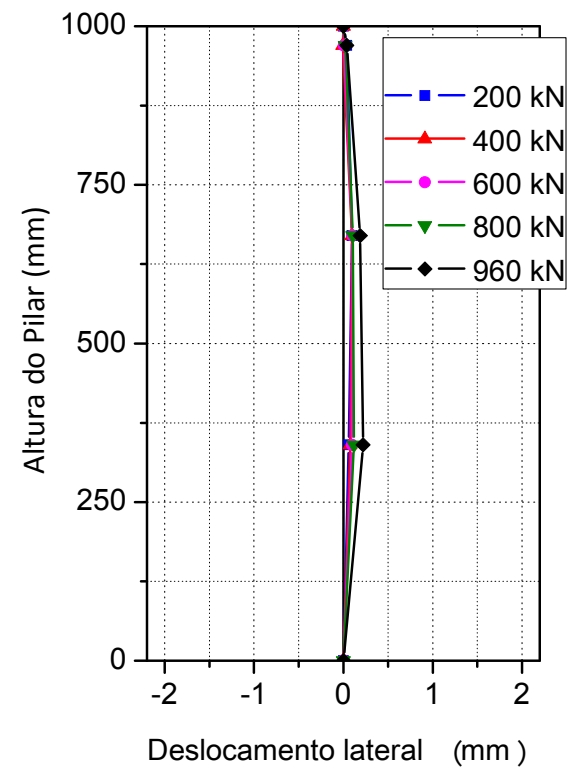

(a)

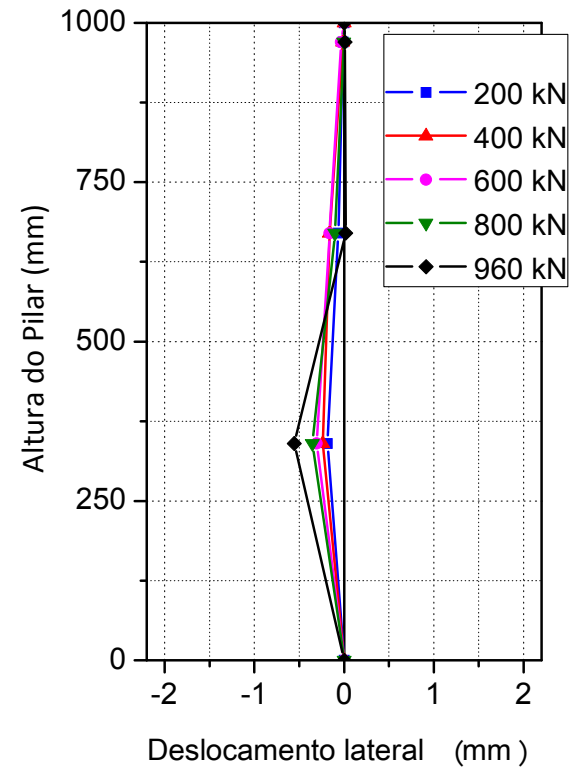

(b)

Figura 4.20 - Deslocamentos laterais compensados para o Modelo M1-R: (a) Face 3; (b) Face 4

As curvas da Figura 4.20 demonstram que houve pequenos valores de deslocamento laterais, entretanto pode-se notar uma curvatura simples em ambas as faces avaliadas, indicando uma possível flexão gerada por uma excentricidade acidental, nas duas direções. Percebe-se que na face 4 os valores de deslocamento aumentam próximo à base para a força máxima, mudando a configuração deformada final.

O gráfico da Figura 4.21 apresenta as curvas Força aplicada vs. Encurtamento vertical para os modelos M2 e M2-R, os quais possuem armadura na forma de telas de aço soldadas. Além disso, é plotada a curva Força aplicada vs. Encurtamento vertical média para o modelo com armadura convencional.

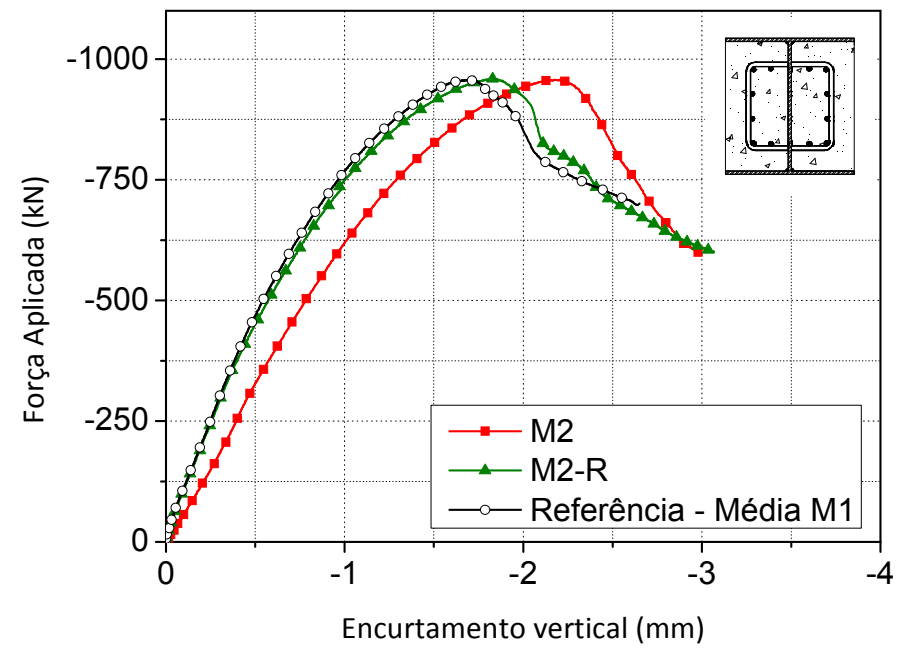

Figura 4.21 - Curva Força Aplicada vs. Encurtamento vertical para os modelos M2 e M2-R 
Ao se comparar as curvas do gráfico da Figura 4.21 observa-se que o comportamento global apresentado pelos modelos M2 e M2-R é similar ao apresentado pelo modelo com armaduras convencionais, com valores de capacidade resistente e capacidade de deformação plástica bastante próximos. Já em termos de rigidez observa-se que o modelo M2 apresenta a rigidez levemente inferior ao modelo M2-R. A capacidade resistente alcançada pelo M2 foi de $954,00 \mathrm{kN}$ e de $950,00 \mathrm{kN}$ para o modelo M2-R, menos de $1 \%$ de diferença para o valor médio obtido para o Modelo 1.

Na Figura 4.22 é apresentado, ainda para o Modelo M2, os deslocamentos laterais (com correção) registrados pelos transdutores de deslocamento, posicionados em faces perpendiculares entre si para vários níveis de força aplicada. Cabe ressaltar que foram registrados deslocamentos mínimos na face 4 e maiores na face 3, indicando possível excentricidade acidental na direção do eixo de menor rigidez durante a aplicação do carregamento.

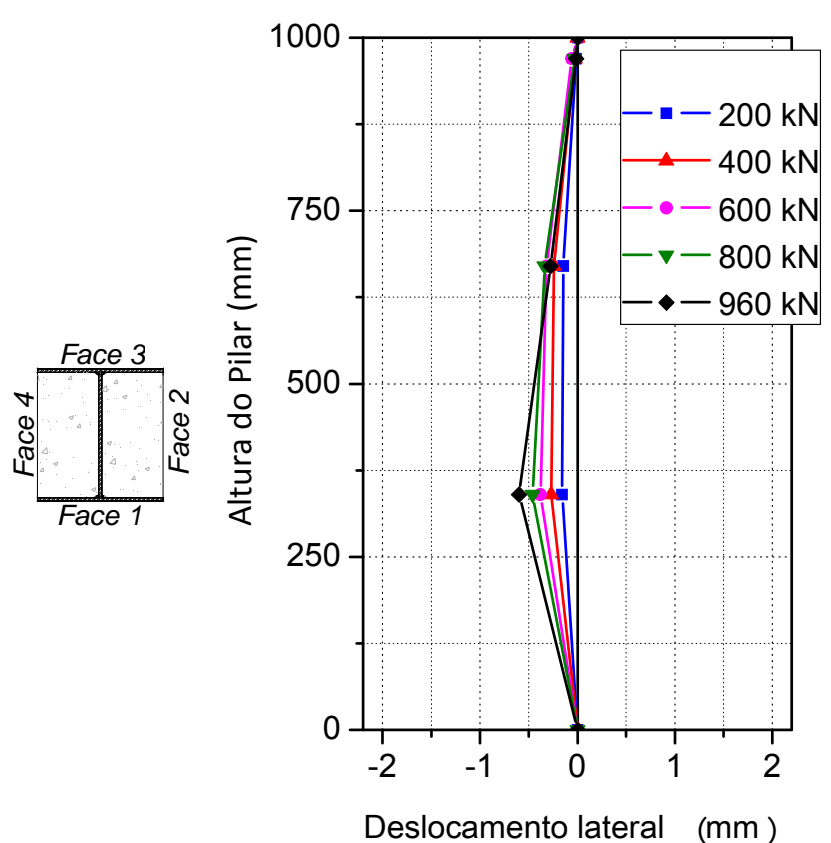

(a)

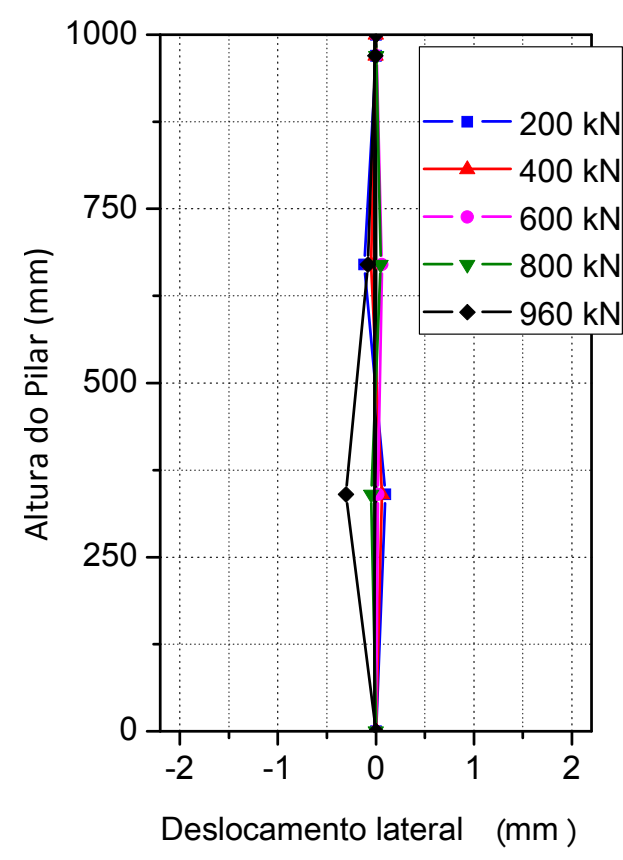

(b)

Figura 4.22 - Deslocamentos laterais compensados para o Modelo M2: (a) Face 3; (b) Face 4

O comportamento irregular para os deslocamentos laterais na face 4 pode estar associado ao fato destes deslocamentos serem muito pequenos de modo que nem sempre o sistema de aquisição de dados consegue registrá-los com a precisão adequada. 
$\mathrm{Na}$ face 3, os deslocamentos laterais apresentam crescimento regular com $\mathrm{o}$ incremento da força aplicada, onde se pode visualizar uma curvatura simples de flexão do pilar, com valores de deslocamento semelhantes entre pontos simétricos até próximo à força máxima. Com o aumento da força aplicada até a força máxima, o deslocamento do ponto a $670 \mathrm{~mm}$ da base diminuiu o que, provavelmente, está associado ao deslocamento abrupto na face 4, para este mesmo nível de carregamento ocasionando o deslocamento do pilar para uma nova posição deformada.

No que tange ao modelo 3, o gráfico da Figura 4.23 apresenta as curvas Força aplicada vs. Encurtamento vertical para os modelos M3 e M3-R, os quais não apresentam armaduras na forma de barras, mas são revestidos de concreto com adição de fibras.

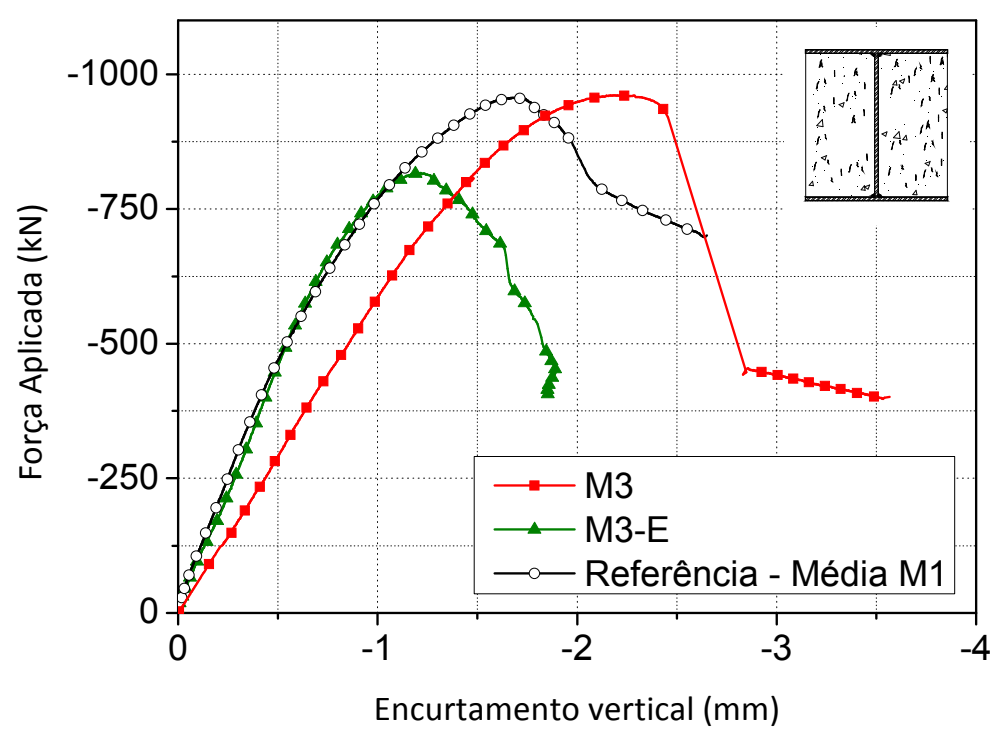

Figura 4.23 - Curva Força Aplicada vs. Encurtamento vertical para os modelos M3 e M3-E

A capacidade resistente do modelo M3 foi de $961 \mathrm{kN}$, enquanto a média obtida para o modelo 1 foi de 958,50 kN. De modo que, apesar da diferença nos valores de resistência do concreto convencional e com adição de fibras (aproximadamente 17\% menor para o concreto com fibras) não houve variação na capacidade resistente do elemento misto estudado.

Já o modelo M3-R apresenta menor capacidade resistente (aproximadamente $816 \mathrm{kN}$ ) como esperado, uma vez que está submetido à flexo-compressão. Foi observada uma redução de $15 \%$ na capacidade resistente do modelo M3-E em relação ao modelo M3.

As curvas Força aplicada vs. Encurtamento vertical (Figura 4.23) revelam que o modelo M1 médio é mais rígido que o modelo M3. Entretanto, o modelo M1 e o modelo M3E apresentam mesma rigidez. Assim, não se pode atribuir às fibras a perda de rigidez, 
podendo ter ocorrido algum problema durante o ensaio do modelo $\mathrm{M} 3$, como por exemplo, o mau posicionamento do elemento M3 na Máquina de Ensaios.

Cabe ressaltar que o modelo M2 também possui uma rigidez inferior ao modelo M1médio (referência) e pelos deslocamentos laterais registrados este apresentou uma excentricidade na direção do eixo de menor inércia. Os deslocamentos laterais apresentados na Figura 4.24 também sugerem a ocorrência de uma excentricidade acidental no eixo de menor inércia para o modelo M3. Desta forma, a isto pode estar relacionada à forma de aplicação do carregamento.

Observa-se que os modelos com concreto com fibras (modelo M3 e M3-E) apresentam menor capacidade de deformações no trecho pós-pico da curva quando comparado com o modelo M1, isto é, para pequenos deslocamentos há uma perda significativa de carregamento resistido. Algumas explicações podem ser dadas:

- Menor confinamento no concreto pela ausência da armadura em forma de barras ou tela;

- Não há o escoamento da armadura que contribui para o comportamento mais dúctil de elementos de concreto armado;

- O perfil metálico é mais solicitado no modelo M3 do que nos modelos M1 e M2. Isto pode ser observado nas grandes deformações apresentadas pela alma do perfil metálico do modelo M3 mesmo antes do pico de força (Figura 4.34), o que diminui a possibilidade de um trecho de deformações plásticas do elemento misto no pós-pico, já que o aço do perfil atingiria mais rapidamente a tensão última.

Todavia, observaram-se grandes deslocamentos ainda nos trechos iniciais do ensaio, devido à menor rigidez do modelo M3, desta forma, o valor de deslocamento para a força de pico do modelo M3 foi superior ao valor observado para o modelo M1.

Ainda na Figura 4.24 verifica-se que os deslocamentos na face 3 apresentam valores semelhantes entre pontos simétricos até a força máxima. Já na face 4 , nos primeiros estágios de carregamento os deslocamentos são ínfimos e apenas para a força máxima há um crescimento significativo. 


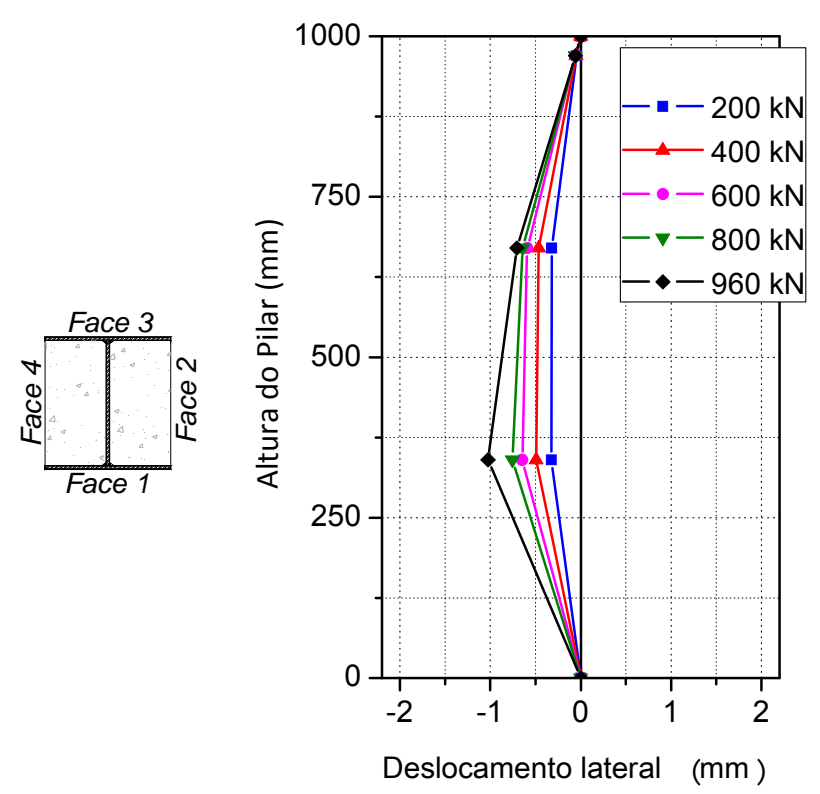

(a)

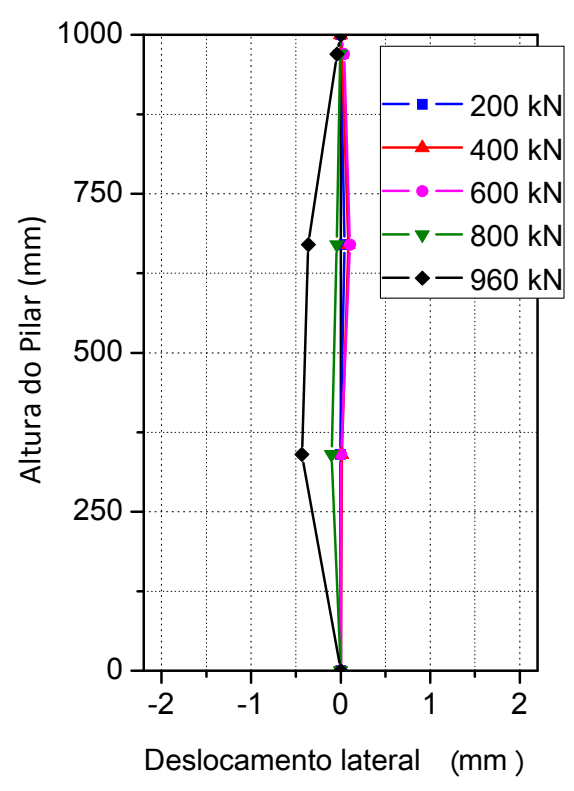

(b)

Figura 4.24 - Deslocamento lateral do modelo M3: (a) Face 3; (b) Face 4

A Figura 4.25 apresenta os deslocamentos laterais registrados pelos transdutores de deslocamento posicionados na face 4 do modelo físico M3-e.

Para o modelo M3-e foram registrados deslocamentos laterais no topo do pilar superiores àqueles registrados para os demais modelos físicos, devido ao mecanismo de aplicação da força excêntrica que facilita o escorregamento do topo. Novamente, este deslizamento foi compensado no gráfico da Figura 4.26, para facilitar a visualização.

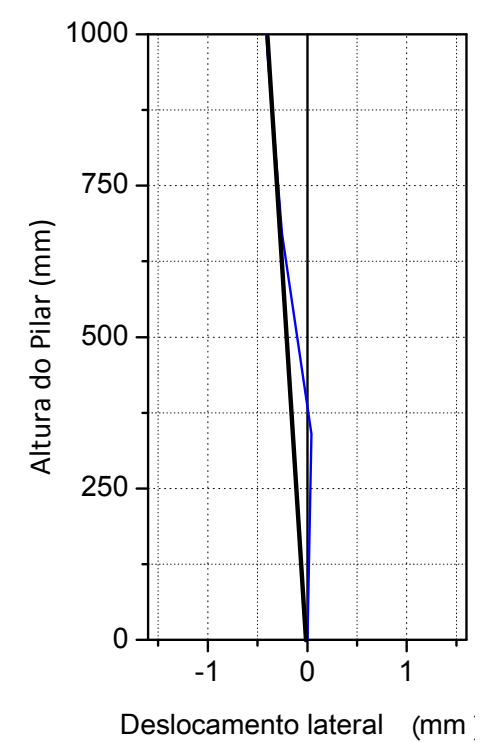

(a)

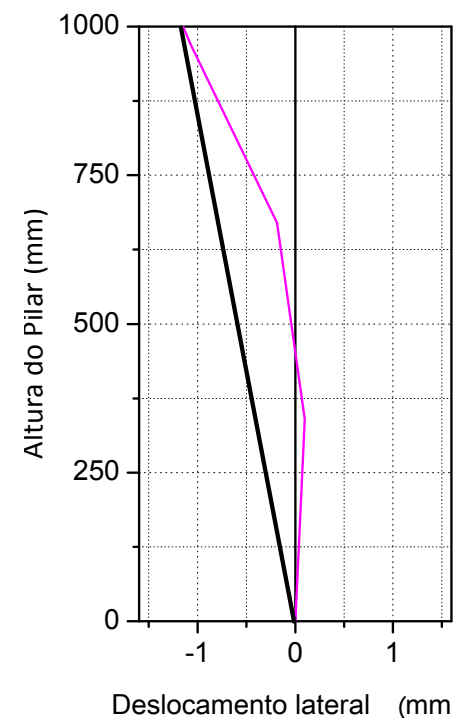

(b)

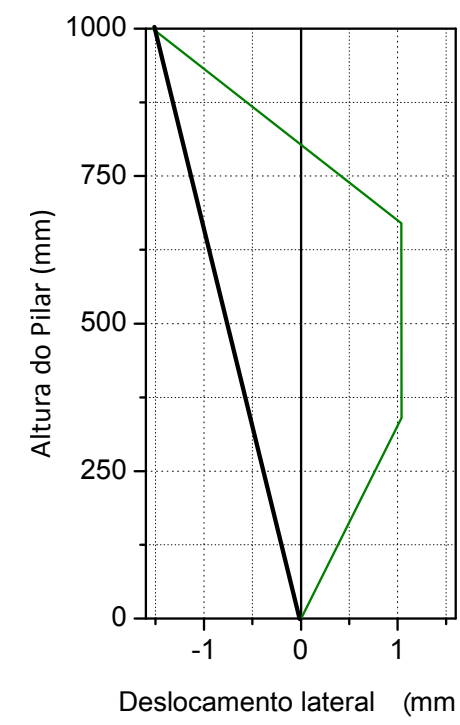

(c)

Figura 4.25 - Deslocamentos para o modelo M3-E: (a) $200 \mathrm{kN}$; (b) $600 \mathrm{kN}$; (c) $900 \mathrm{kN}$ 


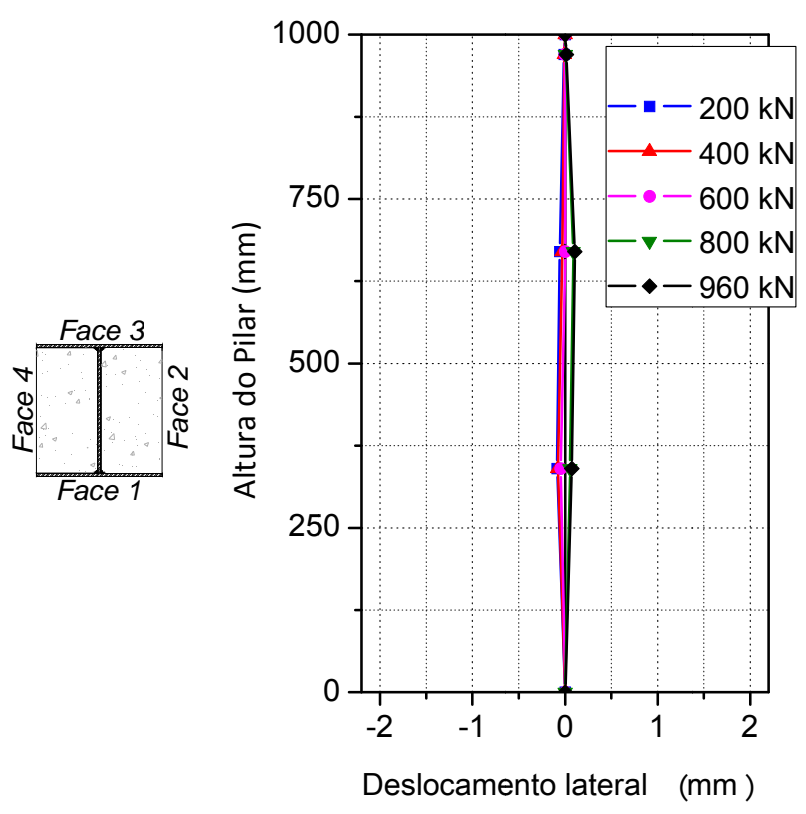

(a)

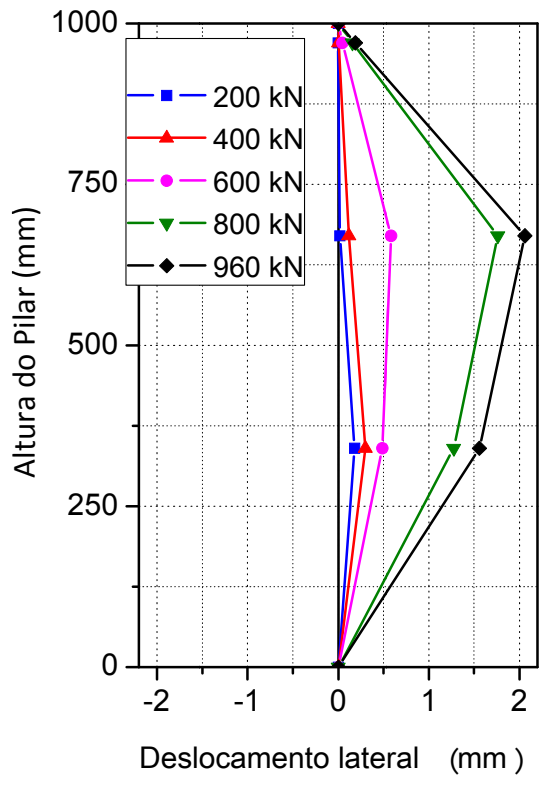

(b)

Figura 4.26 - Deslocamento lateral compensado do modelo M3-e: (a) Face 3; (b) Face 4

O gráfico da Figura 4.26 permite visualizar a formação de uma curvatura de flexão que confirma a ocorrência de flexão no eixo desejado.

\subsubsection{Deformação na mesa do perfil metálico}

A Figura 4.27, Figura 4.28 e Figura 4.29 apresentam as deformações horizontais registradas pelos extensômetros E1 e E7 posicionados nas mesas do perfil metálico (faces 1 e 3) para os modelos físicos ensaios.

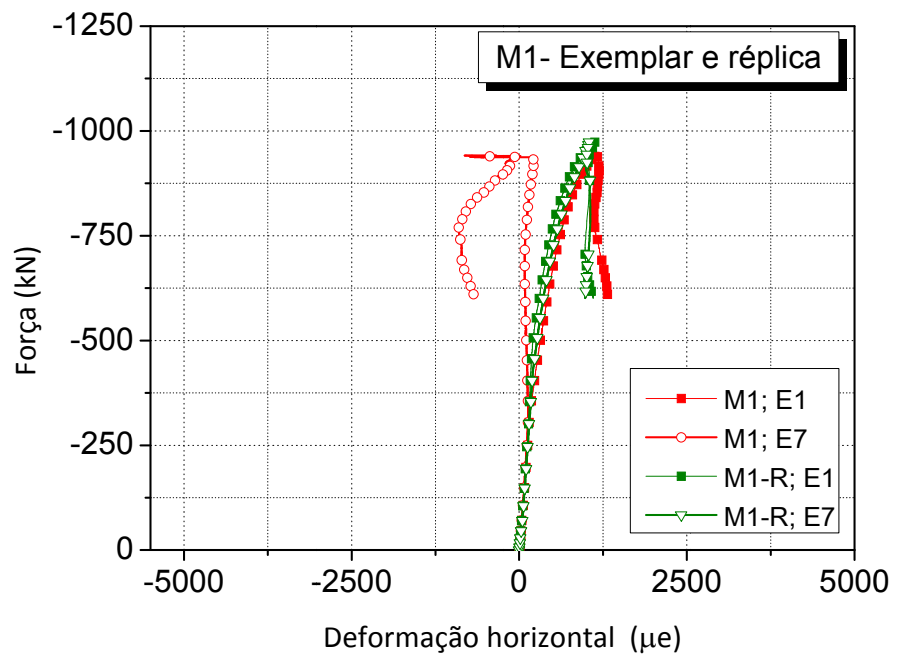

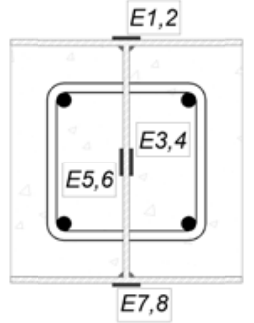

Localização dos extensômetros

Figura 4.27 - Deformações horizontais na mesa dos modelos M1 e M1-R 


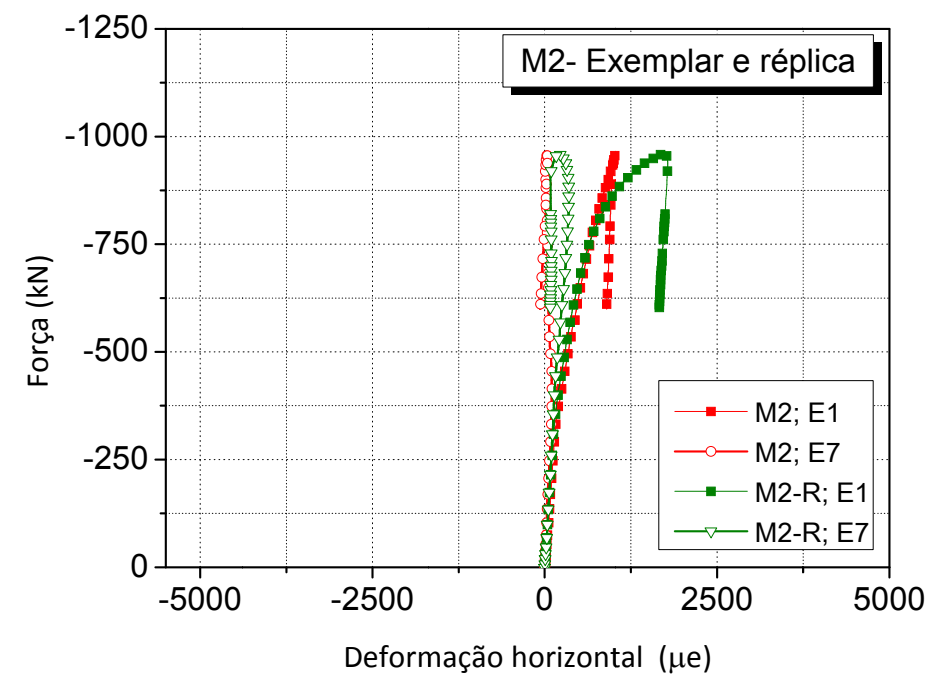

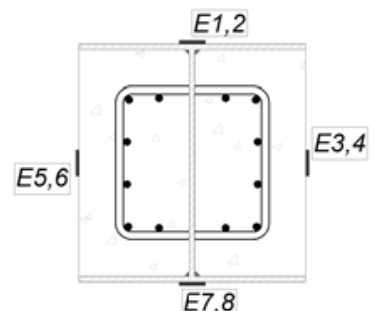

Localização dos extensômetros

Figura 4.28 - Deformações horizontais na mesa dos modelos M2 e M2-R

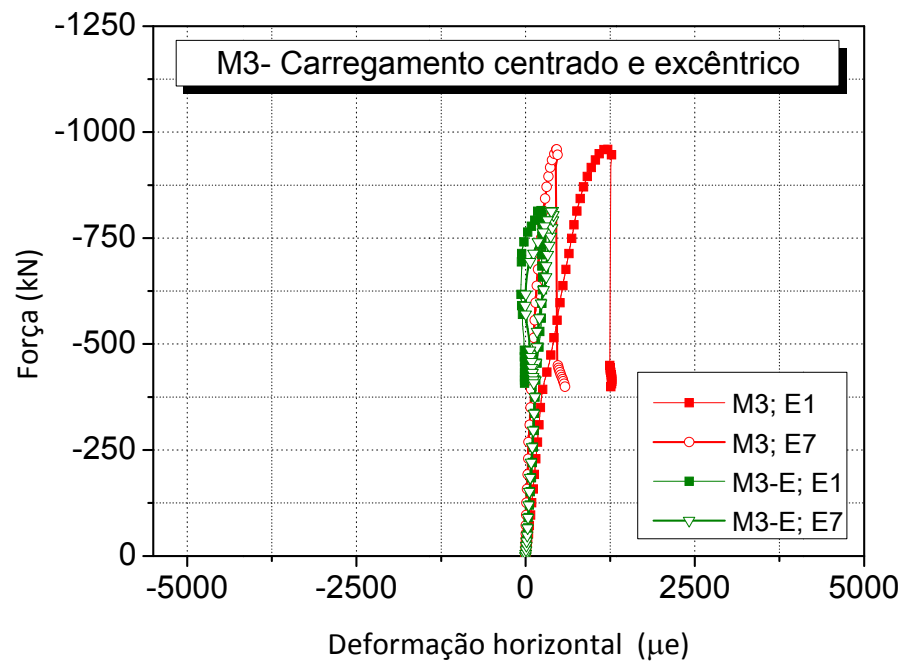

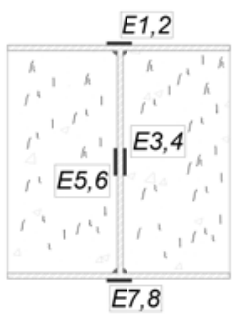

Localização dos extensômetros

Figura 4.29 - Deformações horizontais na mesa dos modelos M3 e M3-E

Em geral, o comportamento das deformações horizontais registradas para as mesas do perfil metálico está coerente com o tipo de solicitação aplicado, uma vez que causa esforços de tração na direção transversal.

Todavia, para o modelo M1 o extensômetro E7 registrou, até a força máxima, deformações de tração pouco expressivas quando comparada com o extensômetro E1 e após a força máxima registrou deformações de compressão. Este comportamento pode ser explicado pela ocorrência da plastificação da região e o aparecimento de instabilidades locais no perfil metálico (ver Figura 4.38). A Figura 4.30 apresenta as deformações verticais na mesa do perfil metálico para os mesmos pontos e os níveis de deformação sugerem a plastificação da seção, confirmando esta suposição. 
Para todos os modelos, as deformações registradas pelos extensômetros E1 e E7 deveriam ser iguais uma vez que a solicitação não deveria apresentar excentricidades no eixo de maior inércia. Entretanto a existência de excentricidades acidentais é inevitável e podem causar diferenças sutis na distribuição de tensões e deformações nas faces dos pilares.

Pode-se verificar ainda que para o modelo M3-E onde foi aplicado carregamento excêntrico no eixo de menor inércia foram registradas as menores deformações horizontais na mesa do perfil metálico.

Em relação às deformações longitudinais do perfil, a Figura 4.30, Figura 4.31 e Figura 4.32 apresentam as deformações obtidas pelos extensômetros E2 e E8 posicionados nas mesas da face 3 e 4 , respectivamente, para os modelos físicos ensaiados.

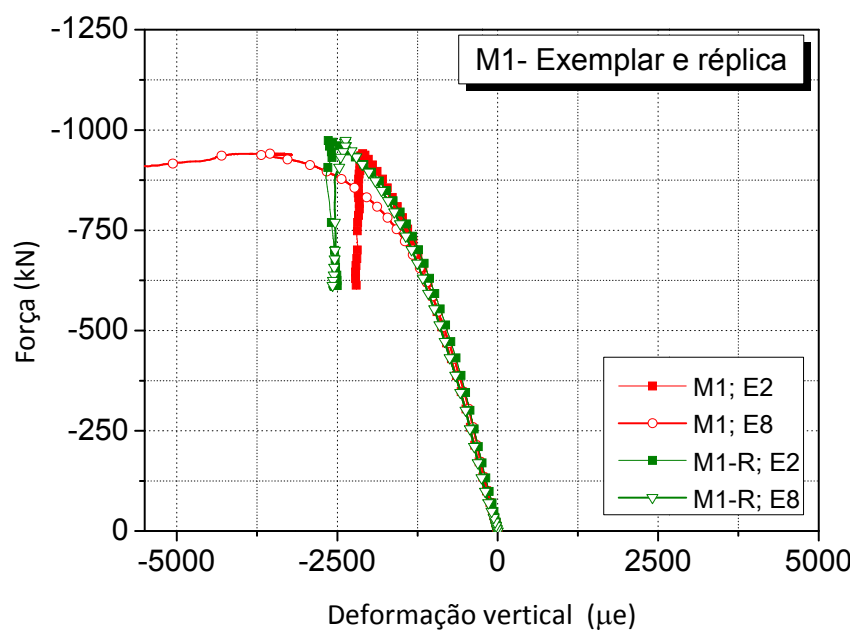

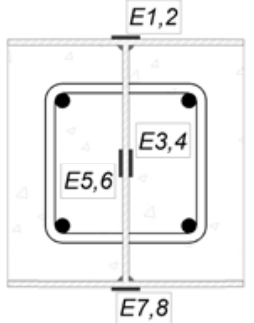

Localização dos extensômetros

Figura 4.30 - Deformações verticais na mesa dos modelos M1 e M1-R

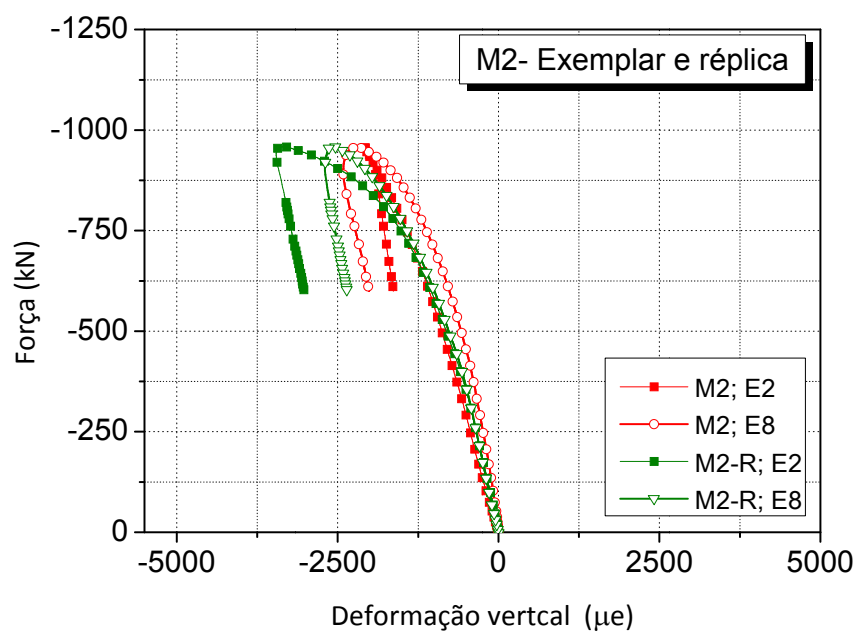

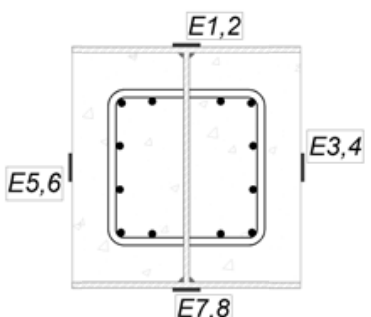

Localização dos extensômetros

Figura 4.31 - Deformações verticais na mesa dos modelos M12 e M2-R 


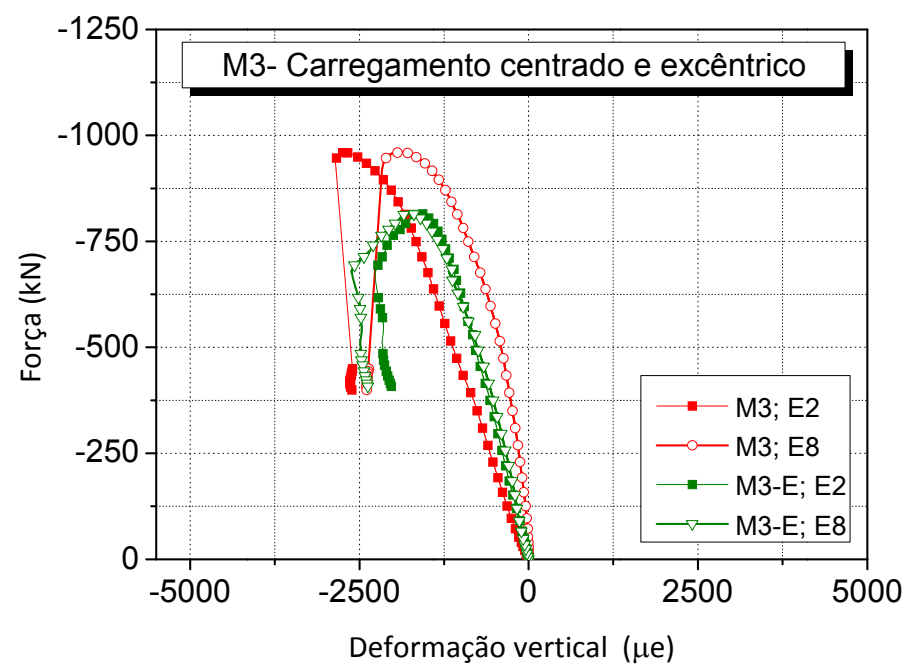

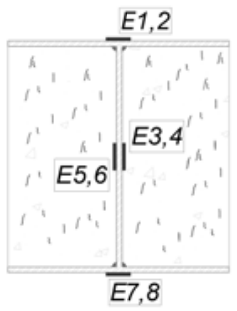

Localização dos extensômetros

Figura 4.32 - Deformações verticais na mesa dos modelos M3 e M3-E

As deformações verticais registradas para a mesa do perfil metálico para os modelos físicos apresentam comportamento condizente com o esperado. Observa-se comportamento similar entre o exemplar e a réplica indicando pouca variedade nos dados e confiabilidade dos resultados obtidos.

A ordem de grandeza das deformações registradas para níveis de carregamento próximos a força máxima indicam a ocorrência de plastificação da região com o surgimento de instabilidades locais como indicado nas Figura 4.38 a Figura 4.44.

Observa-se que após a força máxima as deformações verticais na mesa se mantêm constantes ou diminuem. Apenas o extensômetro E8 do modelo M1 registra grandes deformações indicando que há uma parcela de contribuição da mesa na a capacidade resistente residual do pilar.

\subsubsection{Deformações na alma do perfil metálico}

A Figura 4.27 e a Figura 4.28 apresentam as deformações verticais e horizontais médias da alma do perfil metálico para os modelos físicos M1, M1-R, M3 e M3-E, respectivamente.

As deformações horizontais médias foram obtidas calculando-se a média dos valores de deformações registradas pelos extensômetros E3 e E5, e as deformações verticais médias obtidas por meio da média dos valores de deformações registradas pelos extensômetros E4 e E6. 

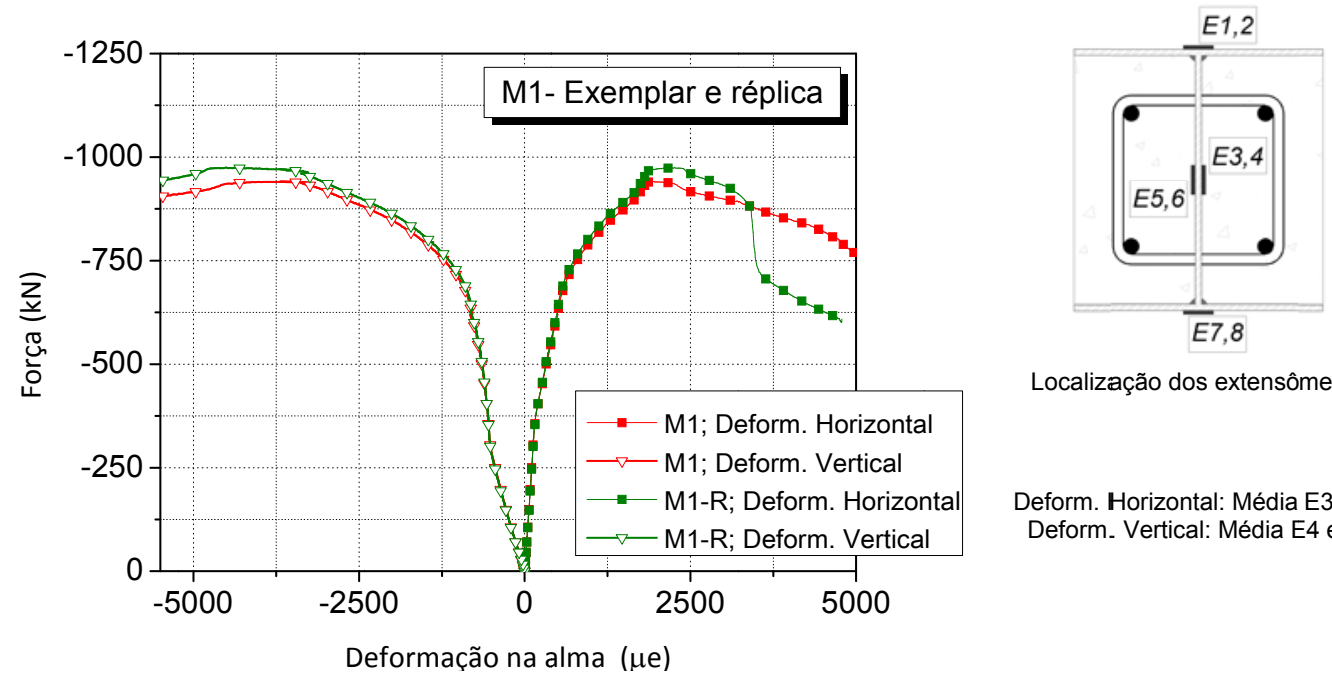

Localização dos extensômetros

Deform. Horizontal: Média E3 e E5 Deform. Vertical: Média E4 e E6

Figura 4.33 - Deformações horizontais e verticais na alma dos modlelos M1 e M1-R
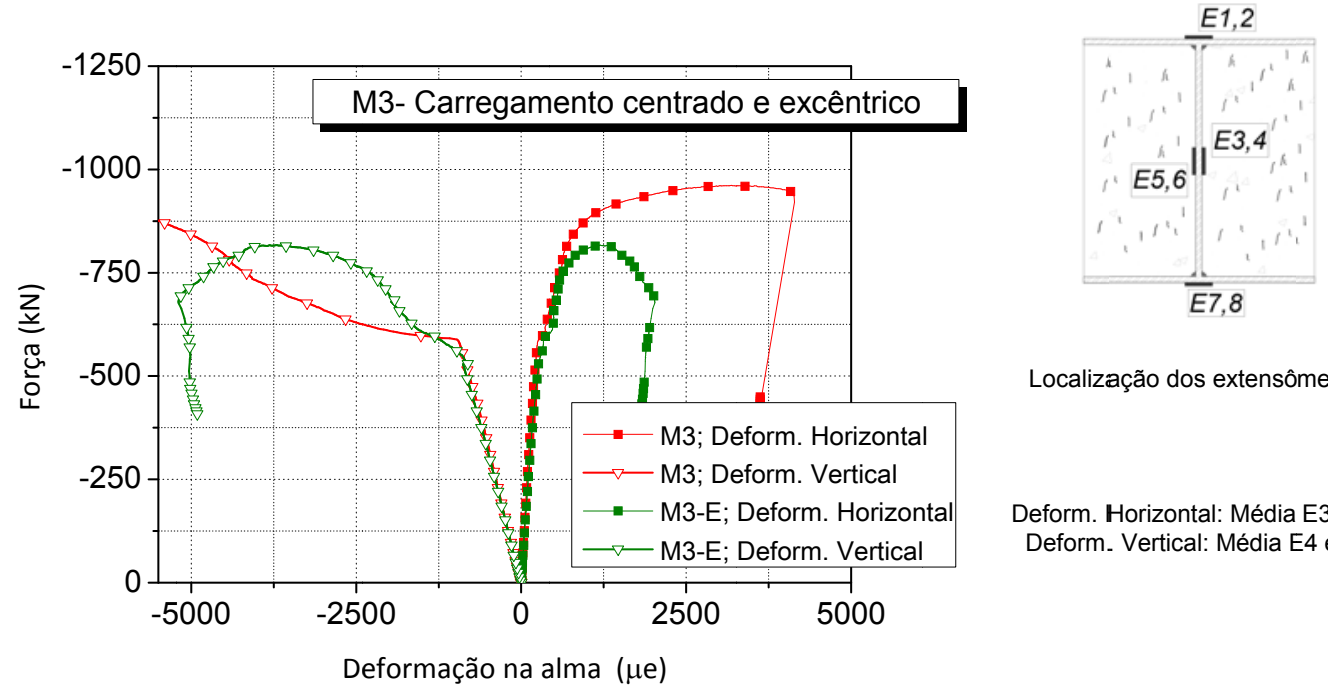

Localização dos extensômetros

Deform. Horizontal: Média E3 e E5 Deform. Vertical: Média E4 e E6

Figura 4.34 - Deformações horizontais e verticais na alma dos modelos M3 e M3-E

Novamente, os registros de deformações estão de acordo com o esperado para a solicitação aplicada e, além disso, há boa correlação entre os resultados obtidos para o exemplar e a réplica. O comportamento das deformações verticais indica que no ponto de força máxima já são registradas grandes deformações na alma, ao passio que no pós-pico são registradas deformações ainda maiores, em especial para os modelos M1 e M1-R, sugerindo que a plastificação da região da alma é a principal responsável pela capacidade resistente no pós-pico e ductilidade do pilar.

No caso do modelo M3, constata-se pelas deformações verticais que a alma foi mais solicitada que nos modelos M1 e M1-R, já que a ordem de grandeza das deformações indica que a plastificação da região ocorreu para níveis de força menores que para o modelo M1. 
As deformações horizontais de tração registradas para a alma do perfil metálico nos modelos M1, M1-R e M3 são maiores que as registradas para a mesa do perfil metálico para os mesmos modelos físicos, indicando também maior participação da alma na capacidade resistente do pilar.

\subsubsection{Deformações no concreto}

Como mencionado anteriormente, no item 4.5.1, para o modelo M2 não foi possível posicionar os extensômetros na alma do pilar metálico devido às pequenas dimensões da tela, de modo que estes foram transferidos para a face 2 e 4 e posicionados no concreto.

A Figura 4.35 apresenta as deformações verticais e horizontais médias registradas para as faces leste e oeste do modelo M2 e M2-R.
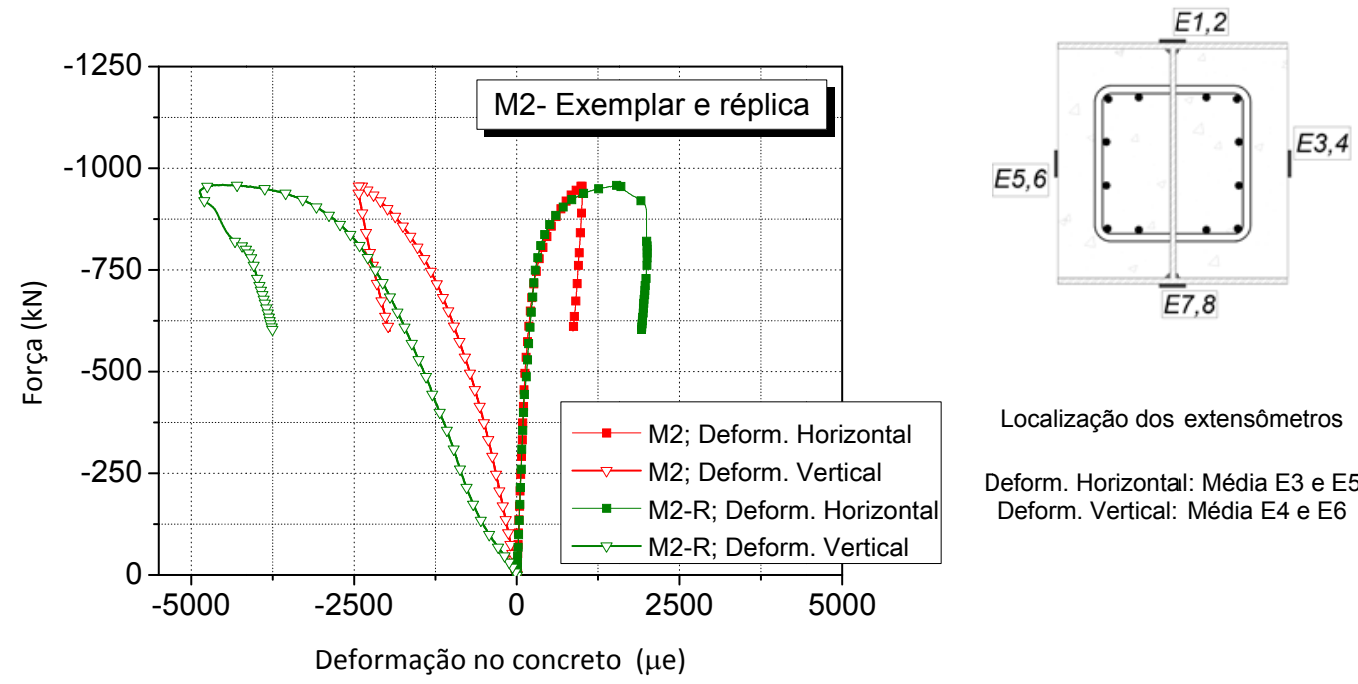

Localização dos extensômetros

Deform. Horizontal: Média E3 e E5 Deform. Vertical: Média E4 e E6

Figura 4.35 - Deformações no concreto para os modelos M2 e M2-R

Os registros de deformações no concreto indicam capacidade de deformação plástica, que pode ser atribuída ao confinamento exercido pelo perfil metálico e armaduras, quando existente.

\subsubsection{Deformações na armadura}

A Figura 4.36 apresenta as deformações registradas para as armaduras longitudinais posicionadas nas faces 2 e 4 do modelo M1 e M1-R. 


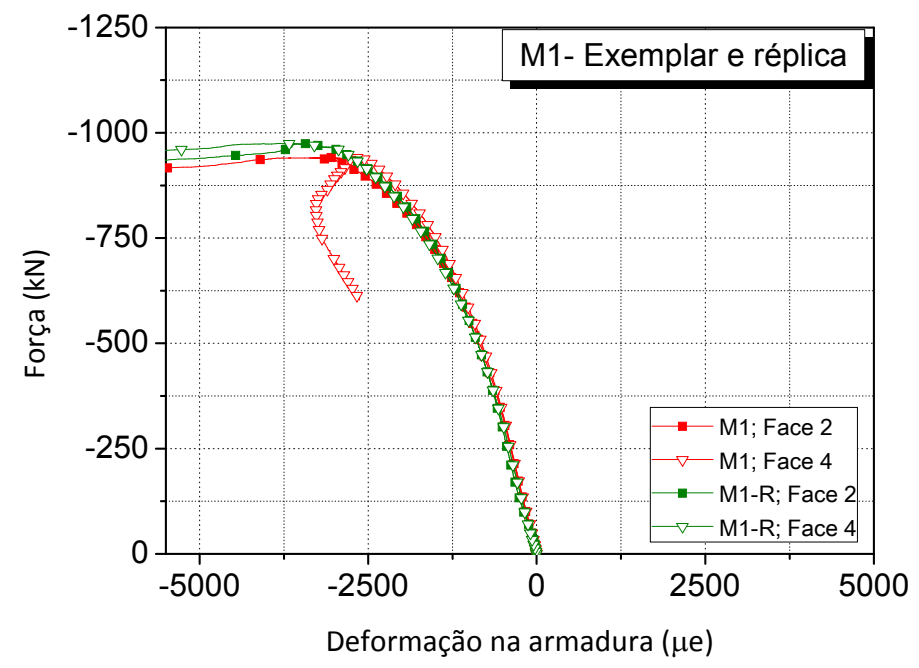

Figura 4.36 - Deformações registradas para a armadura longitudinal

Nota-se que as deformações registradas para a armadura longitudinal indicam contribuição destas para a ductilidade do pilar misto.

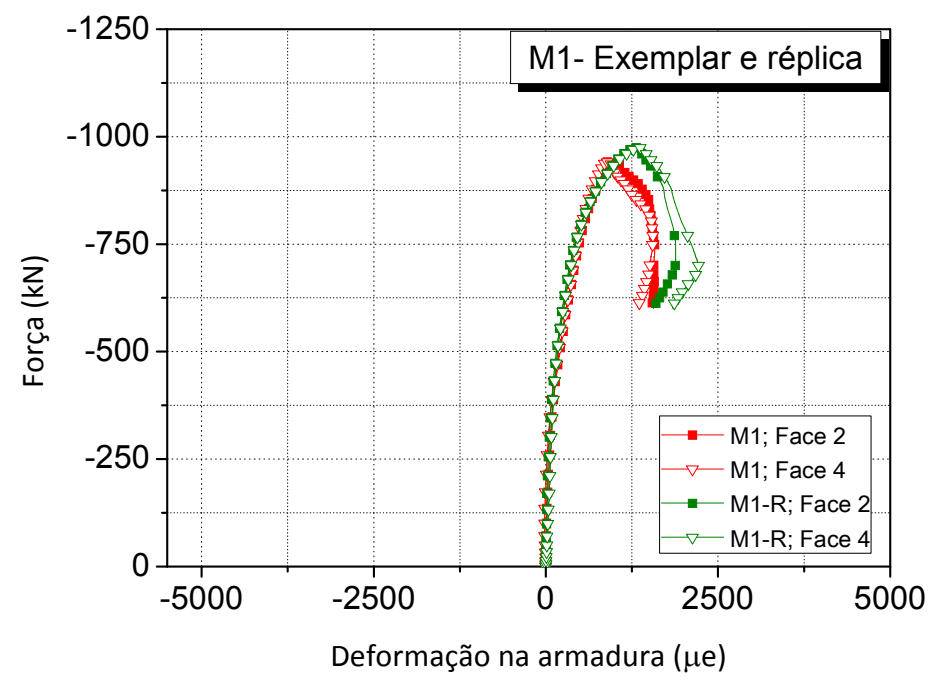

Figura 4.37 - Deformações registradas para a armadura transversal

Já a armadura transversal tem deformações expressivas apenas para o pós-pico.

\subsubsection{Configuração final}

A seguir são apresentadas as configurações finais dos modelos físicos após a realização dos ensaios.

A Figura 4.38 e a Figura 4.39 apresentam a configuração final para os modelos M1 e M1-R respectivamente. 
Durante o ensaio, os primeiros sinais de fissuração do concreto, descolamentos entre os materiais e instabilidade local no perfil metálico foram observados para uma força equivalente a $55 \%$ da força máxima para os modelos M1 e M1-R, isto é, observados a partir de um elevado nível de carregamento. Após a força máxima foi identificada uma intensificação das instabilidades locais na região da mesa (ELU-FLM) como poder ser visto nas Figura 4.38 e Figura 4.39. Vale salientar que mesmo o perfil metálico tenha sido escolhido respeitando a relação de largura e espessura das chapas para haver problemas de instabilidades locais esta ocorreu antes da carga de pico.

Observa-se comportamento similar entre o exemplar e a réplica, nos quais ocorreu o escoamento do aço do perfil em conjunto com o esmagamento do concreto. Apesar dos valores distintos de resistência do concreto nas faces 2 e 4 nota-se que o fendilhamento e as fissuras no concreto são compatíveis nas duas faces, não indicando uma tendência de ruptura na face com menor ou maior resistência do concreto.

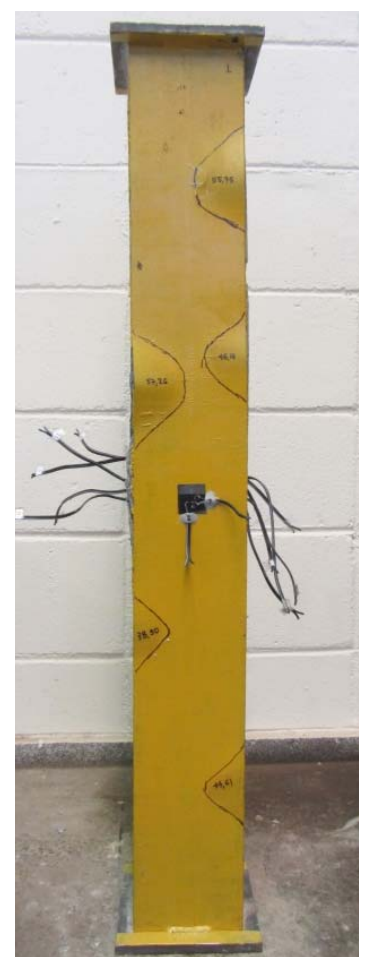

(a)

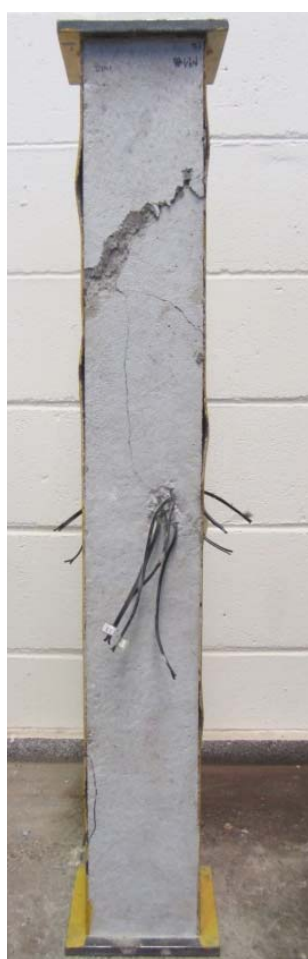

(b)

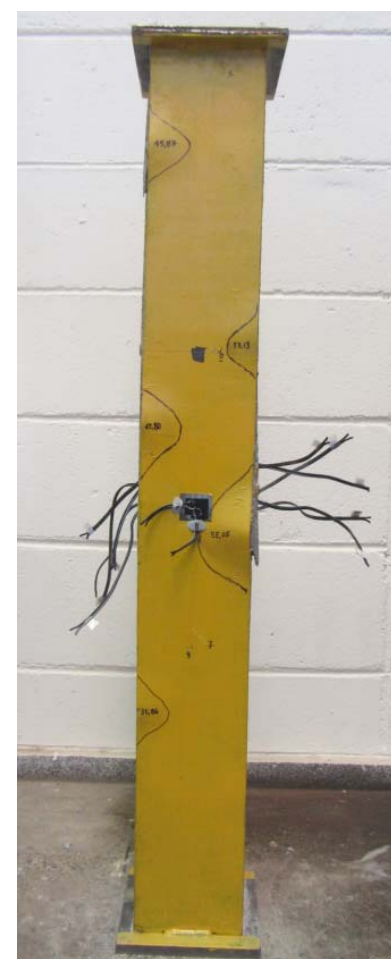

(c)

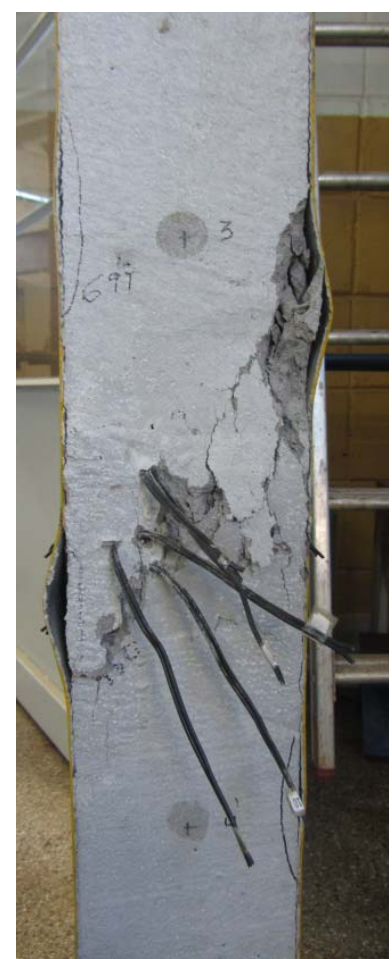

(d)

Figura 4.38 - Configuração Final do Modelo M1: (a) Face 1; (b) Face 2; (c) Face 3; (d) Face 4

Em ambos a ruína foi caracterizada pelo esgotamento da seção mista, com a perda da capacidade de suportar acréscimos de força axial ocorrendo acréscimos de deslocamentos e deformações. 


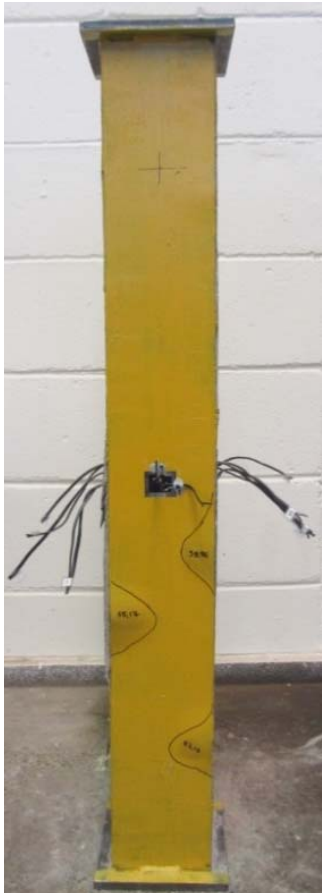

(a)

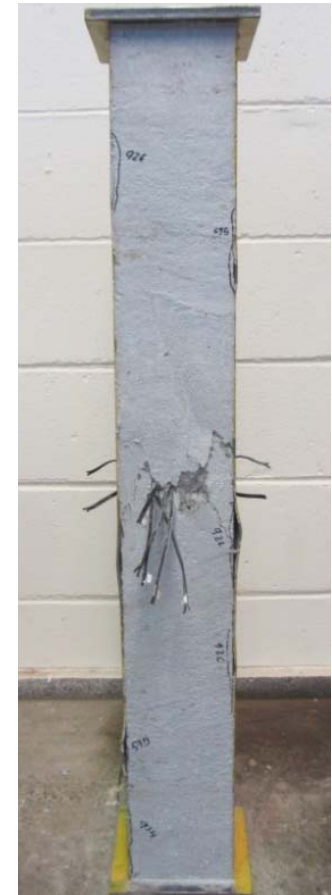

(b)

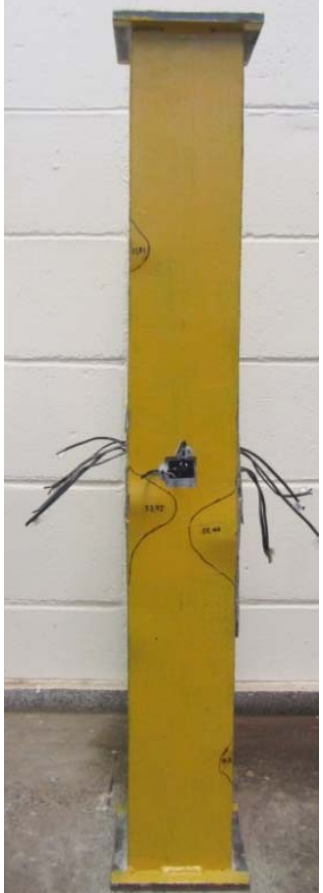

(c)

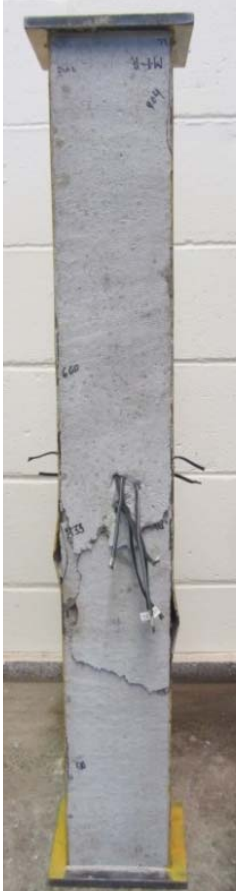

(d)

Figura 4.39 - Configuração Final do Modelo M1-R: (a) Face 1; (b) Face 2; (c) Face 3; (d) Face 4

Já a configuração final dos modelos M2 e M2-R é apresentada nas Figura 4.40 e Figura 4.41. Observa-se comportamento similar entre eles.

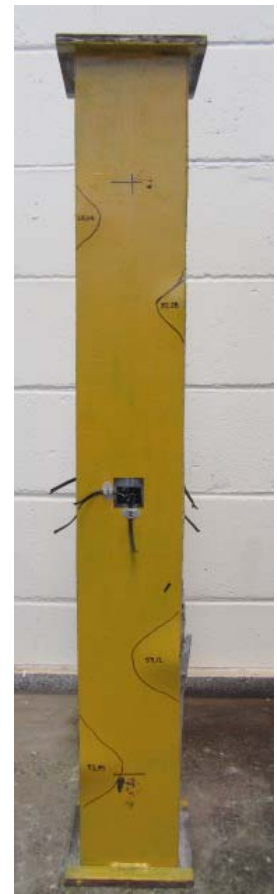

(a)

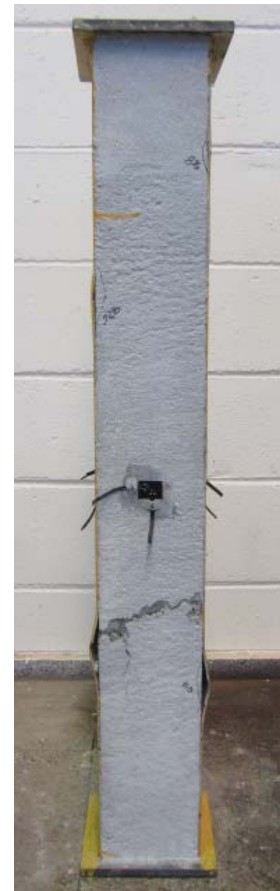

(b)

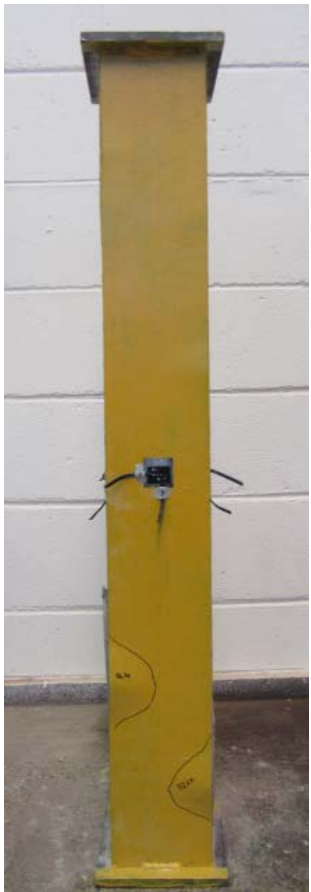

(c)

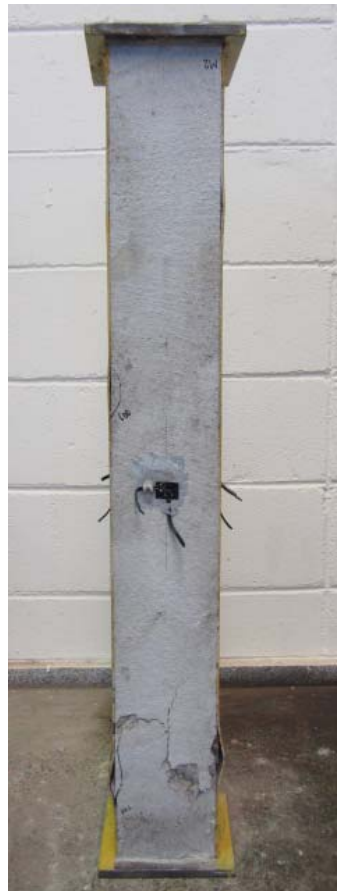

(d)

Figura 4.40 - Configuração Final do Modelo M2: (a) Face 1; (b) Face 2; (c) Face 3; (d) Face 4 


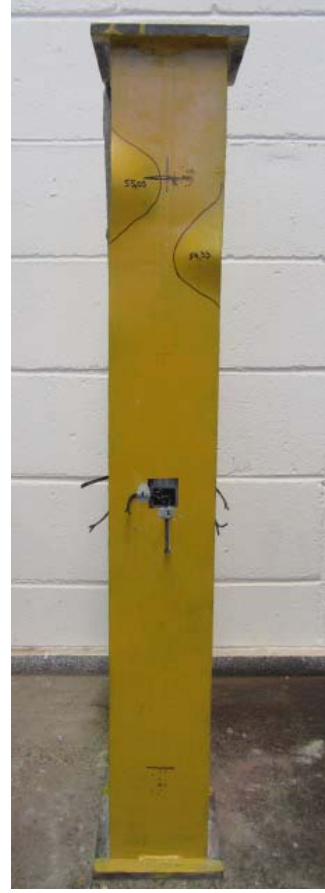

(a)

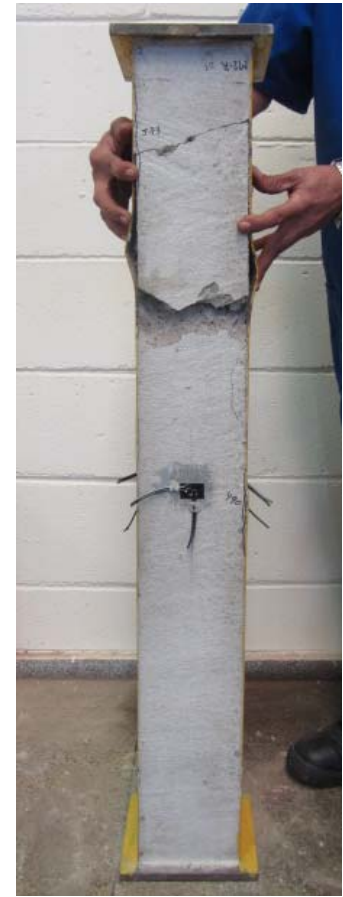

(b)

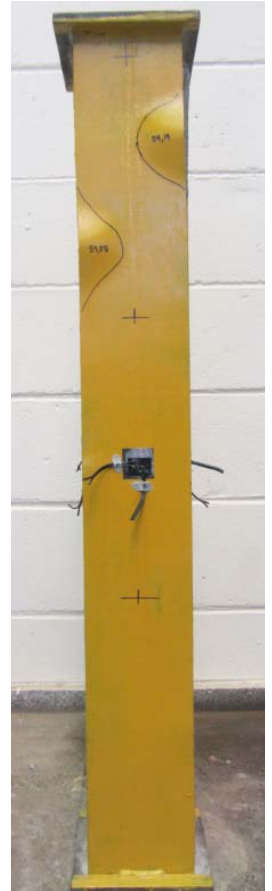

(c)

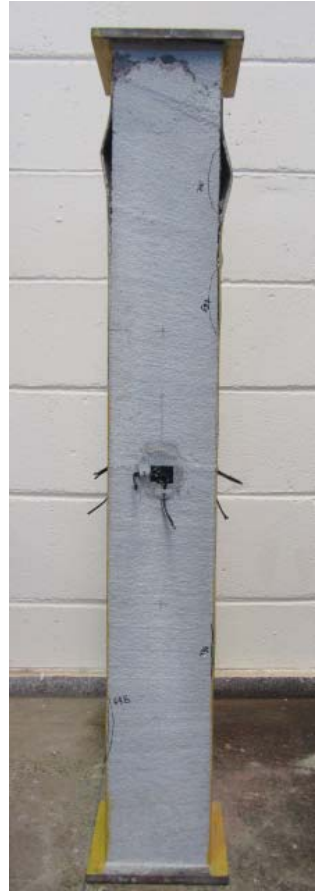

(d)

Figura 4.41 - Configuração Final do Modelo M2-R: (a) Face 1; (b) Face 2; (c) Face 3; (d) Face 4

A perda de aderência entre o aço do perfil e o concreto inicia-se em pontos isolados para força correspondente a $50 \%$ da força máxima para os modelos M2 e M2-R. A partir de uma força equivalente a $95 \%$ da força máxima evidencia-se um crescimento significativo da instabilidade local e deformações no perfil metálico.

As fissuras no concreto ocorreram próximas às extremidades e em menor intensidade do que para o modelo M1 e M1-R. A Figura 4.42 apresenta detalhe do escoamento da tela de aço no modelo M2-R. A ruína também foi caracterizada pelo esgotamento da capacidade resistente da seção mista.

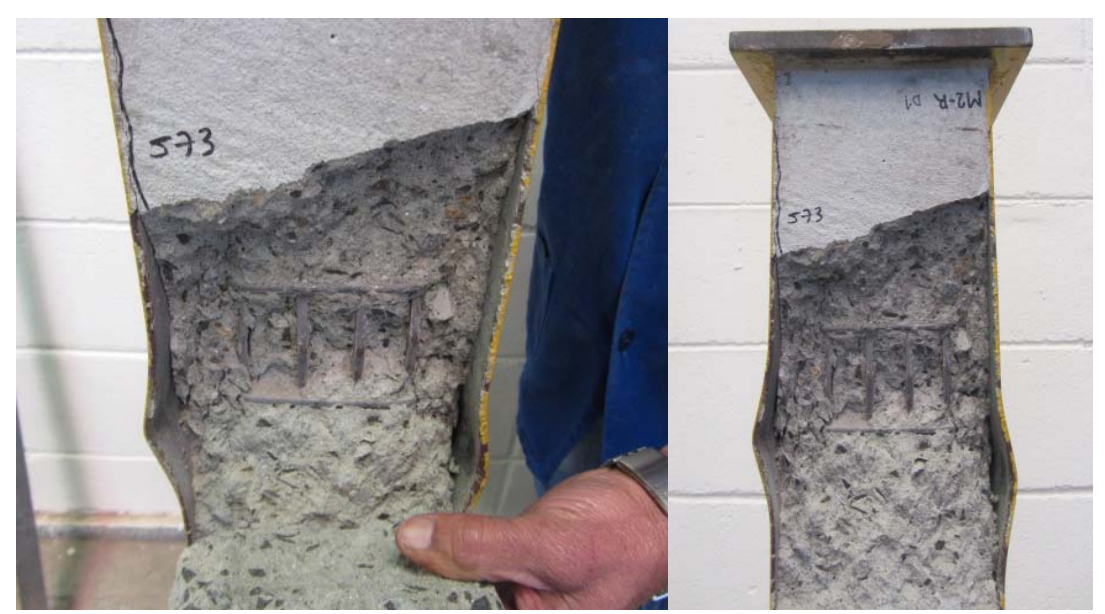

Figura 4.42 - Escoamento da tela de aço no modelo M2-R 
Finalmente para o modelo M3 a Figura 4.43 apresenta a sua configuração final. Os primeiros sinais de instabilidade local do perfil metálico apareceram para uma força de aproximadamente $75 \%$ da força de pico. Não foram observadas fissuras no concreto até a força máxima. A ruína ocorreu de maneira menos dúctil pelo esgotamento da capacidade resistente da seção mista.

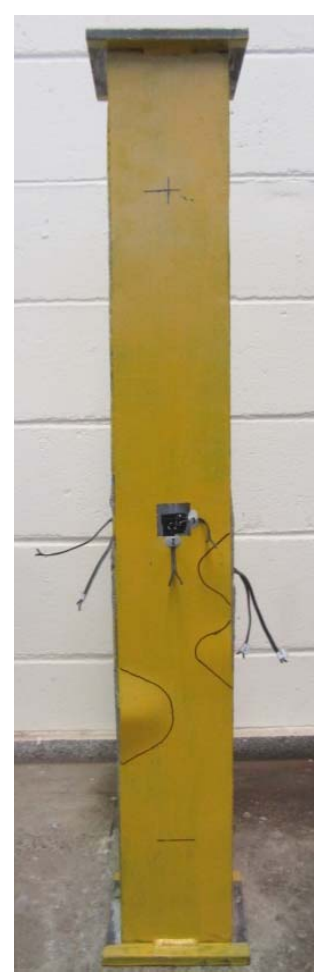

(a)

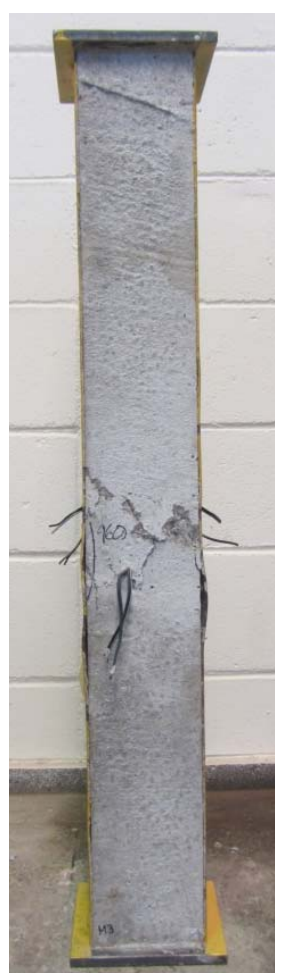

(b)

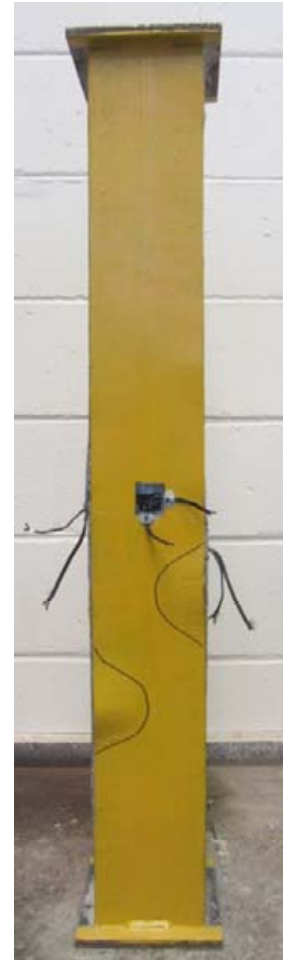

(c)

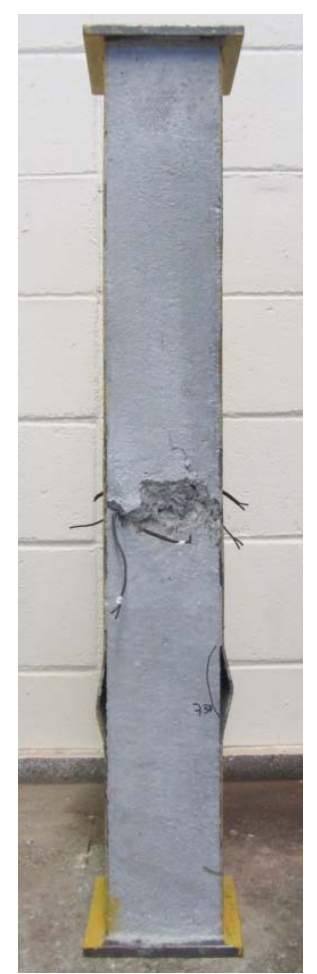

(d)

Figura 4.43 - Configuração Final do Modelo M3: (a) Face 1; (b) Face 2; (c) Face 3; (d) Face 4

A Figura 4.44 mostra a configuração deformada final do modelo M3-e. 


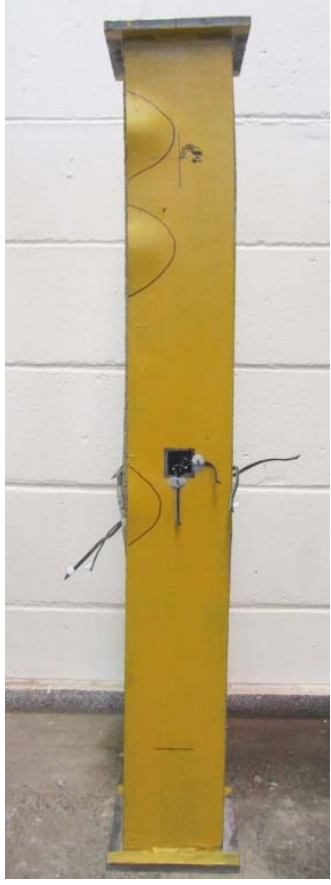

(a)

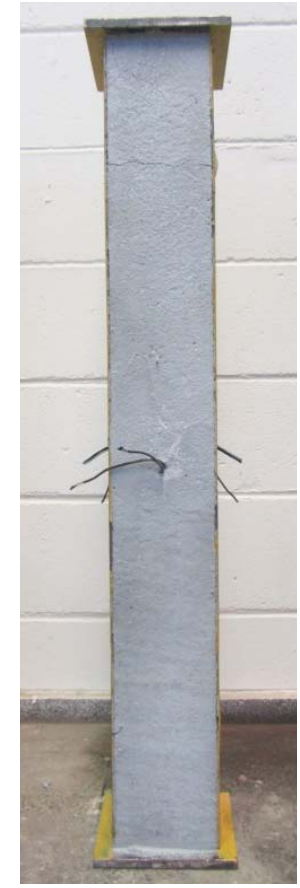

(b)

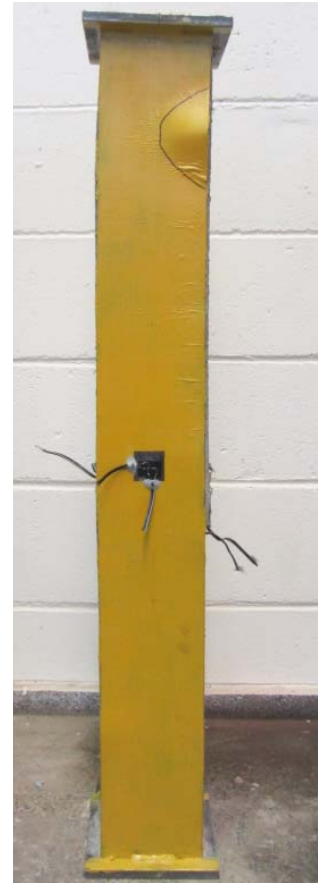

(c)

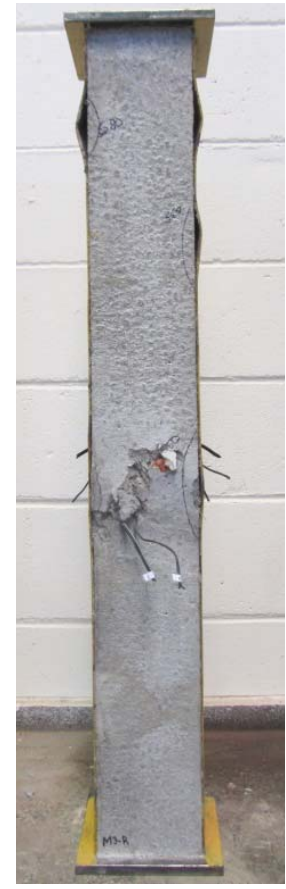

(d)

Figura 4.44 - Configuração Final do Modelo M3-E: (a) Face 1; (b) Face 2; (c) Face 3; (d) Face 4

Observa-se claramente a formação de uma curvatura que confirma a existência de excentricidade na aplicação do carregamento para este elemento. Os primeiros sinais de instabilidade local no perfil metálico e de perda de aderência entre o aço e o concreto ocorreram para uma força correspondente a $70 \%$ da força máxima. Também foi observada perda rápida da capacidade resistente após a força máxima, sem grande capacidade de deformação.

\subsection{Comparação entre os resultados experimentais e normativos}

A Tabela 4.11 mostra os resultados de força máxima obtidos nos ensaios experimentais e a comparação com os valores obtidos com os procedimentos da ABNT NBR 8800:2008 descritos no Capítulo 3. São apresentadas a força normal resistente $\left(N_{R d}\right)$ e a força normal máxima obtida com os procedimentos de cálculo do Modelo I e II considerandose o momento produzido pela excentricidade imposta de $10 \mathrm{~mm}$ (modelo M3-E). Os cálculos detalhados são apresentados no Apêndice A. 
Tabela 4.11 - Relação entre a força experimental e numérica para os pilares

\begin{tabular}{|c|c|c|c|c|c|c|c|}
\hline \multicolumn{2}{|c|}{ Modelo } & \multirow{3}{*}{$\begin{array}{c}\mathbf{F}_{\text {exp }} \\
943,00\end{array}$} & \multirow{3}{*}{$\begin{array}{c}\mathbf{N}_{\mathbf{R d}} \\
1073,66\end{array}$} & \multicolumn{2}{|c|}{ Força Máxima } & \multicolumn{2}{|c|}{$F_{\text {exp }} / F_{\text {norma }}$} \\
\hline & & & & \multirow[t]{2}{*}{ Modelo I } & \multirow[t]{2}{*}{ Modelo II } & & \\
\hline Modelo 1 & M1 & & & & & & \\
\hline & M1-R & 974,00 & & & & & \\
\hline Modelo 2 & M2 & 954,00 & 1056,34 & & & & \\
\hline & M2-R & 950,00 & & & & & \\
\hline Modelo 3 & M3 & 961,00 & 883,78 & & & & \\
\hline & M3-E & 816,00 & & 600 & 790 & 1,360 & 1,033 \\
\hline Média (exc & M3-E) & & & & & & \\
\hline Desvio & & & & & & & \\
\hline
\end{tabular}

Os resultados experimentais mostraram-se sensivelmente inferiores aos resultados analíticos. Em média, os valores experimentais para os modelos onde foi aplicado o carregamento centrado foram $6,5 \%$ inferiores aos obtidos por meio dos procedimentos normativos.

Já para o modelo M3-E, onde o carregamento foi aplicado com uma excentricidade com o valor igual a $10 \mathrm{~mm}$, o resultado experimental foi superior às estimativas obtidas tanto pelo Modelo de cálculo I como pelo II, aproximadamente, $36 \%$ e 3\%, respectivamente. Assim, percebe-se que os modelos subestimam a capacidade resistente do elemento misto flexo-comprimido.

\subsection{Considerações finais}

Este capítulo abordou a metodologia e resultados da investigação experimental. Com a realização dos ensaios experimentais foi possível avaliar, mesmo que simplificadamente, características estruturais e construtivas.

No que tange à execução, verificou-se que a concretagem realizada na horizontal facilita o processo construtivo e elimina a utilização de formas, todavia deve ser realizada separadamente para cada lado. Com isto, no mesmo elemento misto há concretos com idades e propriedades mecânicas distintas. Apesar disto, não foi observada nenhuma consequência negativa para o comportamento estrutural, não houve tendência de ruptura em nenhuma das faces, seja ela com maior ou menor resistência do concreto de modo que cada componente do pilar misto foi solicitado de acordo com sua rigidez e resistência.

Em todos os pilares mistos estudados, ao se avaliarem as deformações registradas pode-se perceber que a alma do perfil metálico apresenta grandes valores de deformação no 
trecho pós-pico da curva força vs. deslocamento. Isto sugere que a alma contribui significativamente para a capacidade resistente residual do elemento em estudo. Já a mesa do perfil metálico exibe instabilidades locais para a força máxima, as quais se intensificam no trecho pós-pico, diminuindo assim sua contribuição para a capacidade resistente do conjunto.

O modelo 1, constituído por armaduras convencionais com barras de aço na forma de vergalhões apresentou comportamento bastante dúctil. A capacidade resistente foi de $943 \mathrm{kN}$ e $974 \mathrm{kN}$, para o exemplar e réplica, respectivamente. O comportamento estrutural global do modelo 2, onde foram utilizadas telas de aço soldadas, foi similar ao modelo 1 em termos de rigidez, capacidade de deformação e capacidade resistente, resistindo a $954 \mathrm{kN}$ e $950 \mathrm{kN}$, o exemplar e a réplica, respectivamente. O modelo M3, onde foi utilizado concreto com fibras e aplicação de compressão axial teve uma capacidade resistente também bastante próxima (958 kN), porém apresenta menor rigidez e capacidade de deformação. Não se pode afirmar com clareza o que levou à diminuição destes parâmetros; acredita-se que o fato esteja associado ao mau posicionamento deste na máquina de ensaios e possíveis excentricidades acidentais.

O modelo M3-E, que foi submetido a flexo-compressão com excentricidade de $10 \mathrm{~mm}$ apresentou uma redução de $15 \%$ na capacidade resistente em comparação com o modelo de referência (modelo 1). Identificou-se neste modelo físico a mesma rigidez do modelo M1 e capacidade de deformação sutilmente menor. Este modelo foi ensaiado para avaliar o comportamento conjunto na situação onde não há armaduras e o pilar esta solicitado a esforços de flexo-compressão. Pode-se observar que mesmo nesta situação os materiais trabalham em conjunto sem a perda precoce da aderência.

Cabe destacar que em todos os ensaios experimentais ocorreram deslizamentos da extremidade superior do pilar e excentricidades acidentais na aplicação do carregamento, assinalando a dificuldade da aplicação de um carregamento centrado, seja em laboratório ou em obras reais. 


\section{Simulações Numéricas}

\subsection{Considerações iniciais}

As simulações numéricas foram utilizadas para auxiliar na caracterização do concreto com fibras de aço por meio da análise inversa do ensaio de tenacidade como proposto por Araújo, Carmo e Prado (2007). Além disso, as simulações foram empregadas para representar o comportamento dos modelos físicos ensaiados e assim possibilitar a avaliação de outros parâmetros que não puderam ser avaliados experimentalmente, tais como a espessura da chapa do perfil metálico, a resistência do concreto e excentricidades no carregamento aplicado.

A modelagem computacional dos pilares mistos foi realizada em três etapas. A primeira etapa, realizada antes da parte experimental, teve caráter exploratório visando estimar a capacidade resistente da seção transversal. Após a realização da investigação experimental e com base nos resultados obtidos foi feita a calibração e validação do modelo numérico (item 5.3.2). Finalmente foi desenvolvida uma análise paramétrica utilizando o modelo numérico validado.

\subsection{Aspectos da modelagem no FX+ DIANA ${ }^{\circledR}$}

O software DIANA ${ }^{\circledR}$ é um programa em elementos finitos baseado no método dos deslocamentos que possibilita a realização de análises não lineares. Foi desenvolvido em 1972 pela TNO Building and Construction Research na Holanda. Já o FX, desenvolvido pela empresa Midas, é o pré e pós-processador do DIANA ${ }^{\circledR}$.

Este pacote computacional foi escolhido para a simulação numérica desenvolvida neste trabalho devido às características dos modelos constitutivos dos materiais disponíveis no software que possibilitam melhor representação do concreto. As etapas foram:

1. Pré-processamento: Criação da geometria, definição da malha e escolha dos elementos finitos e definição das propriedades mecânicas dos materiais;

2. Processamento: Escolha do tipo de análise (linear ou não linear) e estratégia de solução;

3. Pós-processamento: Visualização dos resultados e comparação com os resultados experimentais. 


\subsubsection{Modelos constitutivos para o concreto}

O concreto possui baixa resistência a esforços de tração de modo que, mesmo quando solicitado por forças de compressão, ocorrem fissuras que modificam a distribuição de tensões e reduzem a rigidez dos elementos estruturais e assim passa a apresentar comportamento não linear. A transmissão de esforços ao longo da zona de fraturamento ocorre devido à sua microestrutura heterogênea onde as microfissuras são descontinuas. Entretanto, essa a transmissão desaparece gradativamente com a abertura das fissuras, caracterizando um processo de amolecimento.

Para modelagem numérica deste comportamento, o software DIANA ${ }^{\circledR}$ contempla a abordagem discreta e distribuída. Na abordagem discreta a malha é desconectada nos nós onde ocorre a fissura enquanto na abordagem distribuída o material é considerado contínuo durante toda a análise, mas localmente a rigidez é reduzida.

$\mathrm{Na}$ fissuração distribuída em um elemento, quando um critério de fissuração é atingido em um ponto de integração, o material passa a ter novas propriedades mecânicas, com menor rigidez. Desta forma, não há introdução de nenhuma fisssura física no modelo.

O software DIANA ${ }^{\circledR}$ v. 9.4.4 possui basicamente dois tipos de modelos de fissuração distribuída: os modelos de fissuração relacionados com a deformação total (Total Strain Crack Models) e modelos de fissuração fixa multidirecional (Multi-Directional Fixed Crack Model).

Os modelos constitutivos baseados na deformação total foram desenvolvidos considerando a Teoria de Campo Modificado de Compressão, originalmente proposta por Vecchio e Collins (1993) e podem ser divididos em dois tipos: fixo e rotacional. No modelo fixo a orientação adotada para a fissura é mantida constante durante a análise, enquanto no modelo rotacional a orientação da fissura pode acompanhar as direções principais de tensões.

Nestes modelos é necessário definir parâmetros básicos, como módulo de elasticidade e coeficiente de poisson, e também definir o comportamento da transferência dos esforços de cisalhamento (total, constante ou variável) atráves da fissura e o comportamento de amolecimento do material (frágil, linear, multilinear ou não linaer). Para isto são necessários parâmetros como: coeficiente de retenção ao cisalhamento $(\beta)$, energia de fraturamento na tração e na compressão $\left(G_{f}\right.$ e $\left.G_{c}\right)$, resistências à tração e à compressão e largura de banda de fissuras ("crack band").

Já os modelos de fissuração fixa multidirecional (Multi-Directional Fixed Crack Model) permitem a abertura de mais de uma fissura em um mesmo ponto de integração de 
Gauss em função do ângulo entre uma fissura existente e outra formada no mesmo ponto definido pelo usuário. Nestes modelos o comportamento do material para tração é representado por um modelo de fissuração distribuída e o comportamento a compressão é representado por modelo plástico. Para isto, é necessário definir parâmetros de transferência dos esforços de cisalhamento atráves da fissura e comportamento de amolecimento do material à tração e critério de ruptura (constante ou linear).

A transferência de esforços cortantes é representada pelo modelo de retenção ao cisalhamento, no qual o surgimento de fissuras reduz a rigidez transversal do material. No pacote computacional DIANA ${ }^{\circledR}$ o módulo de rigidez ao cisalhamento $(\mathrm{G})$ é reduzido para um valor $\beta \cdot G$, onde $\beta$ é o fator de retenção ao cisalhamento $(\operatorname{com} 0,01 \leq \beta \leq 0,99)$. Ao se assumir valores do fator $\beta$ próximos a zero tem-se a rigidez ao cisalhamento do concreto muito pequena, por outro lado, para valores próximos da unidade, considera-se uma rigidez infinita ao cisalhamento, de modo que não haverá a formação de fissuras nesta direção.

A largura de banda de fissuras visa eliminar a influência da malha de elementos finitos nos resultados do modelo constitutivo do material. Esse parâmetro pode ser fornecido pelo usuário ou calculado pelo programa de acordo com o tipo de elemento finito utilizado. Para elementos finitos planos, a largura de banda de fissuração é tomada como a raiz quadrada da área do elemento finito, enquanto para elementos sólidos é considerada como a raiz cúbica do volume do elemento finito.

Para representar os elementos de concreto com adição de fibras de aço no âmbito dos modelos constitutivos disponíveis no software DIANA ${ }^{\circledR}, \mathrm{o}$ amolecimento foi definido por meio dos parâmetros: energia de fraturamento à tração $\left(G_{f}\right)$ e energia de fraturamento à compressão $\left(G_{c}\right)$.

A energia de fraturamento pode ser calculada de duas formas: com base no modelo do CEB-FIB apresentada no Capítulo 3 ou com base no comportamento da curva tensãodeformação, nos ramos de endurecimento e amolecimento do concreto.

\subsection{Determinação indireta da energia de fraturamento em prismas de concreto com fibras}

Os corpos de prova prismáticos de concreto com fibras foram simulados numericamente visando determinar a energia de fraturamento a partir da análise inversa do ensaio de flexão sob quatro pontos. Com base na curva experimental tensão vs. deformação dos corpos de prova prismáticos, foi calibrado um modelo numérico, e da curva numérica 
resultante desta calibração, foi extraído o valor de energia de fraturamento à tração utilizada como dado de entrada nas simulações numéricas dos pilares mistos.

\subsubsection{Hipóteses adotadas na análise inversa do ensaio de tenacidade}

Foi desenvolvido um modelo bidimensional em elementos finitos para representação dos prismas de concreto com as dimensões de $500 \mathrm{~mm}$ x $150 \mathrm{~mm}$ e espessura de $150 \mathrm{~mm}$.

Para este modelo, foi utilizado o elemento Q8MEM, elemento isoparamétrico com quatro nós e dois graus de liberdade por nó. O elemento é baseado na interpolação linear e integração de Gauss. A malha de elementos finitos utilizada possui 240 elemnentos e 287 nós (Figura 5.1).

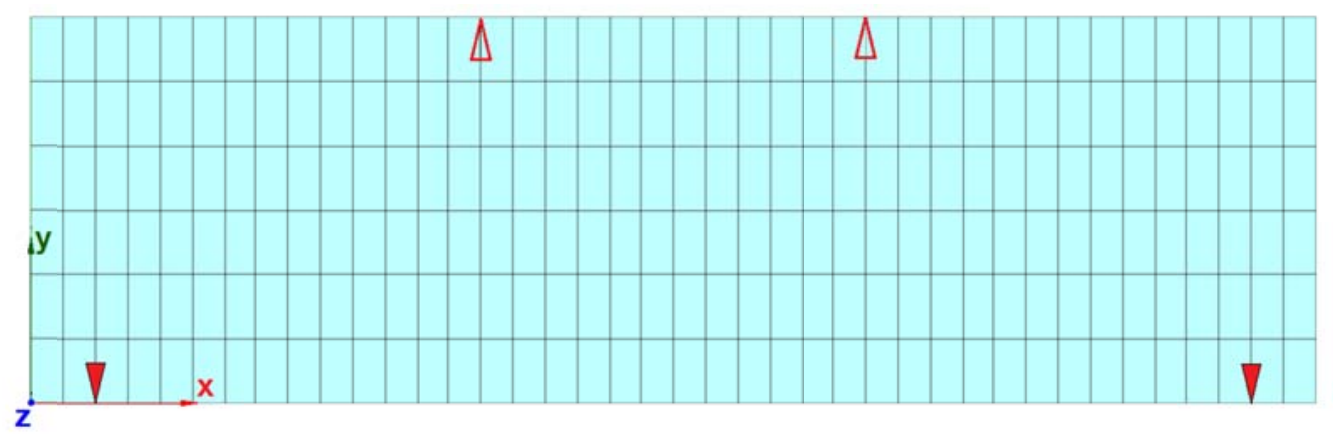

Figura 5.1 - Prisma de concreto com fibras: malha de elementos finitos e condições de contorno

A fim de reproduzir as condições de contorno do ensaio experimental, foram considerados restritos os deslocamentos dos nós da extremidade inferior localizados a $25 \mathrm{~mm}$ da borda vertical. Já o carregamento foi aplicado em dois pontos localizados a $175 \mathrm{~mm}$ das extremidades como indicado na Figura 5.1.

O comportamento do material foi representado pelo modelo o Multi-Directional Fixed Crack Model. Neste, o comportamento do concreto é representado por um modelo de fissuração distribuída para tração e um modelo plástico para compressão. Para representar o amolecimento do material à tração foi utilizada uma curva bi linear (Figura 5.2).

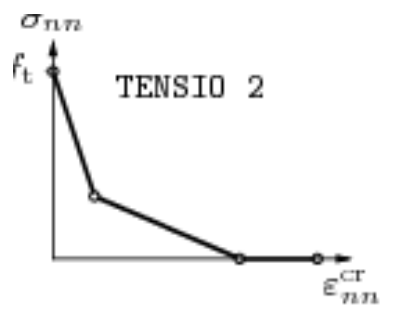

Figura 5.2 - Curva de amolecimento multilinear para os prismas de concreto. DIANA, 2012 
A Tabela 5.1 apresenta um exemplo dos parâmetros necessários para a implementação do modelo Multi-Directional Fixed Crack Model. Os valores de módulo de elasticidade e resistência à compressão foram aqueles obtidos nos ensaios de caracterização.

Tabela 5.1 - Relação constitutiva do concreto dos prismas

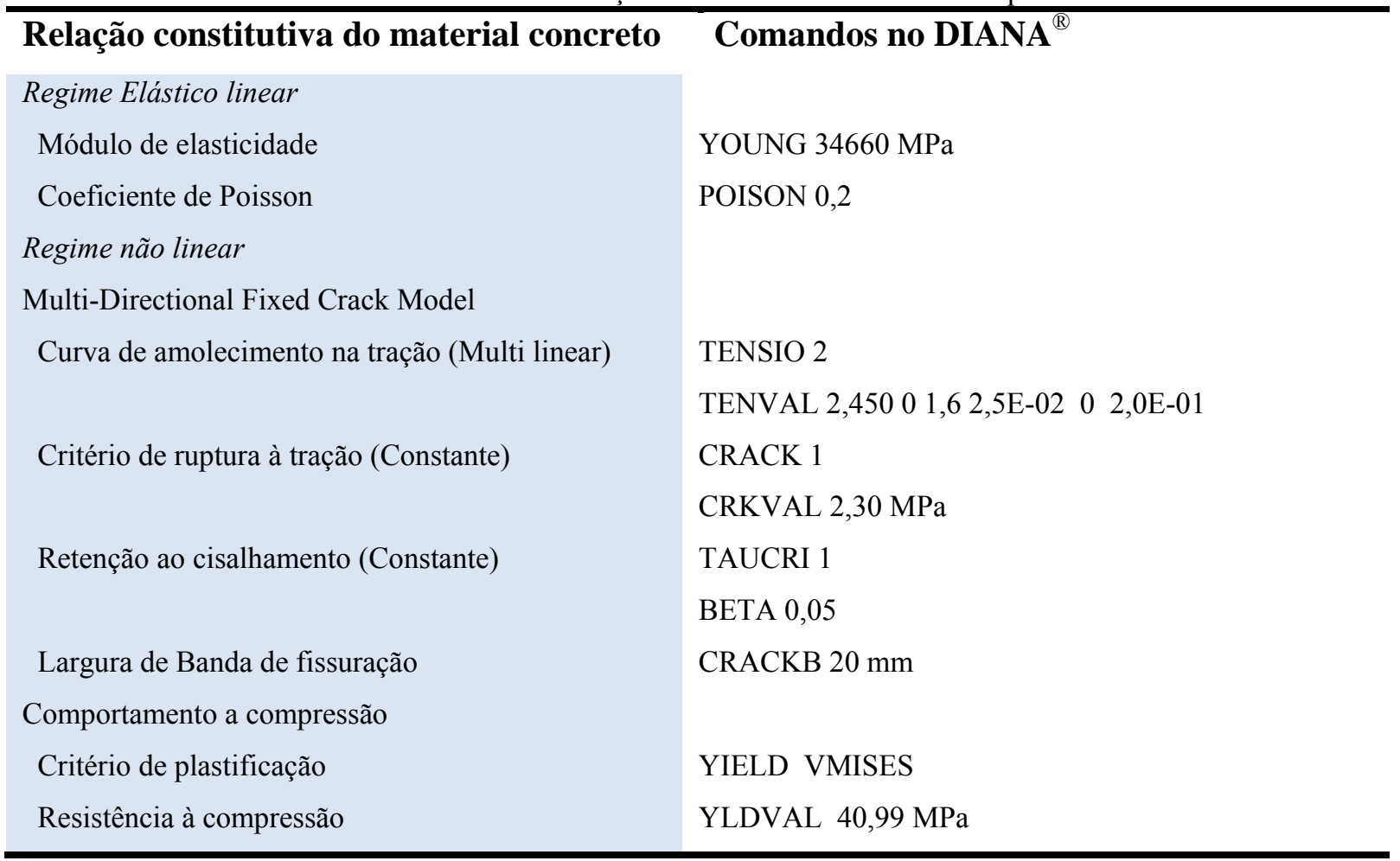

Nos ensaios de flexão sob quatro pontos em prismas de concreto não deveria haver influência das tensões de cisalhamento. Entretanto, no modelo numérico as tensões de cisalhamento têm influência na resposta dos prismas de concreto devido ao elemento finito que não representa fielmente os campos de tensões e deformações. Desta forma, devem-se utilizar valores baixos de beta na análise inversa do ensaio de tenacidade para reduzir a influência do cisalhamento. Vale ressaltar que um valor baixo de beta faz sentido mesmo para o concreto com fibras, pois se trata de um modelo que fissura prioritariamente por tensões normais (modo I).

Como estratégia de solução foi adotado o Método de Newton-Raphson com critério de convergência em energia e tolerância de $10^{-2}$. Foram aplicados passos de $0,025 \mathrm{~mm}$ até a perda de convergência do modelo. 


\subsubsection{Resultados}

Os procedimentos descritos no item 5.3.1 foram utilizados para representar todos os corpos de prova de concreto com adição de fibras ensaiados (CPs 11 a 20). Os parâmetros da curva de amolecimento foram definidos de forma que a resposta numérica se ajustasse à curva força vs. deslocamento do ensaio de tenacidade. A Figura 5.1 apresenta as curvas experimentais e numéricas obtidas para o corpo de prova CP 11. Maiores detalhes da correlação entre os resultados numéricos e experimentais podem ser observados na Tabela 5.2 .

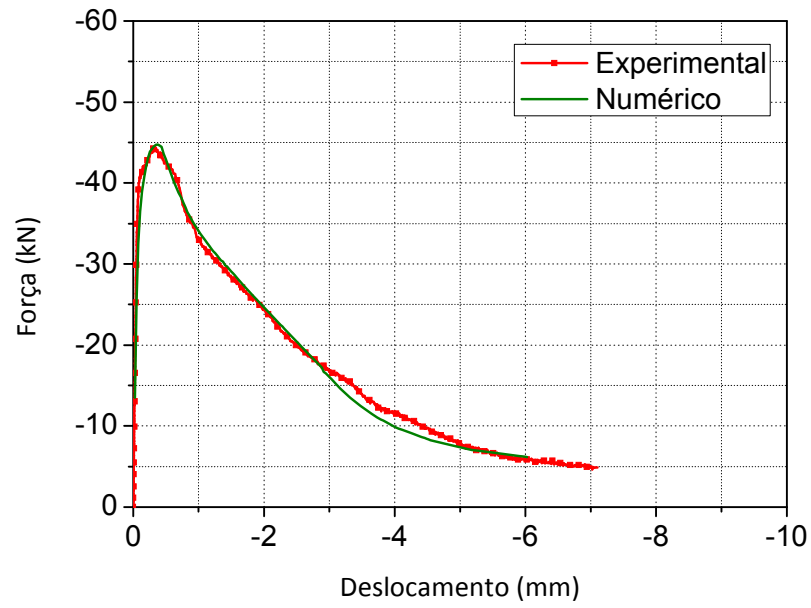

Figura 5.3 - Curva força vs. deslocamento dos ensaios de flexão sob quatro pontos de carga

Tabela 5.2 - Comparação entre os resultados experimentais e numéricos para prismas de concreto

\begin{tabular}{|c|c|c|c|c|c|c|}
\hline $\mathbf{C P}$ & $A_{\text {,exp }}$ & $\mathbf{A}_{\text {,num }}$ & $\mathbf{A}_{\text {,exp }} / \mathbf{A}_{\text {,num }}$ & $\begin{array}{l}F_{\text {máx,exp }} \\
(\mathbf{k N})\end{array}$ & $\begin{array}{l}\text { F }_{\text {máx,num }} \\
(\mathbf{k N})\end{array}$ & $\mathbf{F}_{\text {máx,exp }} / \mathbf{F}_{\text {máx,num }}$ \\
\hline 11 & 117,91 & 115,91 & $-1,70 \%$ & 44,25 & 44,75 & $1,13 \%$ \\
\hline 12 & 94,76 & 88,88 & $-6,21 \%$ & 35,63 & 37,10 & $4,11 \%$ \\
\hline 13 & 93,35 & 90,37 & $-3,20 \%$ & 38,91 & 38,36 & $-1,42 \%$ \\
\hline 14 & 103,36 & 105,43 & $2,00 \%$ & 45,40 & 44,77 & $-1,39 \%$ \\
\hline 15 & 75,11 & 79,74 & $6,17 \%$ & 38,69 & 38,85 & $0,42 \%$ \\
\hline 16 & 54,10 & 54,74 & $1,18 \%$ & 53,94 & 51,85 & $-3,87 \%$ \\
\hline 17 & 107,33 & 107,54 & $0,20 \%$ & 49,83 & 49,63 & $-0,40 \%$ \\
\hline 18 & 122,33 & 122,84 & $0,42 \%$ & 53,72 & 54,74 & $1,91 \%$ \\
\hline 19 & 122,32 & 115,95 & $-5,21 \%$ & 48,91 & 49,69 & $1,59 \%$ \\
\hline 20 & 100,70 & 97,77 & $-2,91 \%$ & 55,32 & 54,92 & $-0,72 \%$ \\
\hline
\end{tabular}


$\mathrm{Na}$ Tabela 5.3 são mostrados os valores das deformações $\varepsilon_{2, \text { num }}$ e $\varepsilon_{3, \text { num }}$ e da resistência à tração direta, $\mathrm{f}_{\mathrm{t}, \text { num }}$, os quais definem a curva tensão versus deformação bi linear (Figura 5.4) para os concretos com adição de fibras avaliados.

Tabela 5.3 - Parâmetros obtidos na simulação numérica do prismas de concreto

\begin{tabular}{|c|c|c|c|c|c|c|c|}
\hline $\mathrm{CP}$ & $\begin{array}{l}\mathbf{f}_{\mathrm{c}, \exp } \\
(\mathrm{MPa})\end{array}$ & $\begin{array}{l}f_{t, \exp }{ }^{*} \\
(\mathrm{MPa})\end{array}$ & $\begin{array}{l}\mathbf{f}_{\mathrm{t}, \mathrm{num}} \\
(\mathrm{MPa})\end{array}$ & $\begin{array}{l}\varepsilon_{2, \text { num }} \\
(\% 0)\end{array}$ & $\begin{array}{l}\varepsilon_{3, \mathrm{num}} \\
(\% 0)\end{array}$ & $\begin{array}{l}G_{f} \\
(N / m)\end{array}$ & $\begin{array}{l}G_{f, \text { med }} \\
(\mathrm{N} / \mathrm{m})\end{array}$ \\
\hline 11 & 40,99 & 4,08 & 2,45 & 25 & 200 & 3430,8 & \\
\hline 12 & 40,99 & 4,08 & 2,00 & 25 & 200 & 2970 & \\
\hline 13 & 40,99 & 4,08 & 2,1 & 25 & 200 & 2993,4 & \\
\hline 14 & 40,99 & 4,08 & 2,5 & 25 & 200 & 3497,4 & \\
\hline 15 & 40,99 & 4,08 & 2,2 & 25 & 200 & 2655 & 3109,32 \\
\hline 16 & 53,22 & 5,57 & 3,1 & 25 & 200 & 4046,4 & \\
\hline 17 & 53,22 & 5,57 & 2,75 & 25 & 200 & 3589,2 & \\
\hline 18 & 53,22 & 5,57 & 3,1 & 25 & 200 & 4046,4 & \\
\hline 19 & 53,22 & 5,57 & 2,75 & 25 & 200 & 3589,2 & \\
\hline 20 & 53,22 & 5,57 & 3,15 & 25 & 200 & 3589,2 & 3772,08 \\
\hline
\end{tabular}

* por compressão diametral

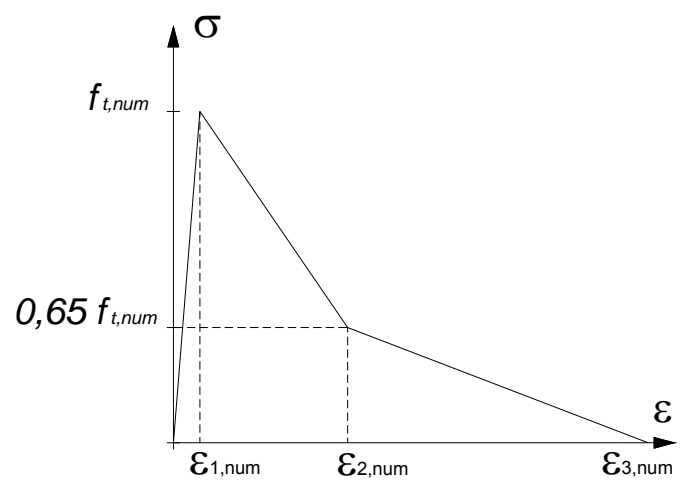

Figura 5.4 - Curva tensão vs. deformação à tração do concreto com adição de fibras de aço

Da curva tensão vs. deformação à tração foi possível calcular a energia de fraturamento na tração, multiplicando-se a área sob o diagrama tensão vs. deformação pela largura de banda de físsuração recomendada pelo programa DIANA ${ }^{\circledR}$. Os valores obtidos para a energia de fraturamento são apresentados na Tabela 5.3.

\subsection{Simulações numéricas de pilares mistos parcialmente revestidos}

\subsubsection{Análises Preliminares}




\subsubsection{Hipóteses}

\section{Características geométricas e Condições de contorno}

Foi desenvolvido um modelo tridimensional cujas características geométricas são apresentadas na Figura 5.5. Uma chapa com material bastante rígido $(\mathrm{E}=1000 \mathrm{GPa})$ foi posicionada na extremidade superior do pilar. O deslocamento foi imposto nos nós desta chapa a qual distribuía para toda a superfície do pilar de maneira uniforme. Nesta etapa o deslocamento foi aplicado centrado no pilar.

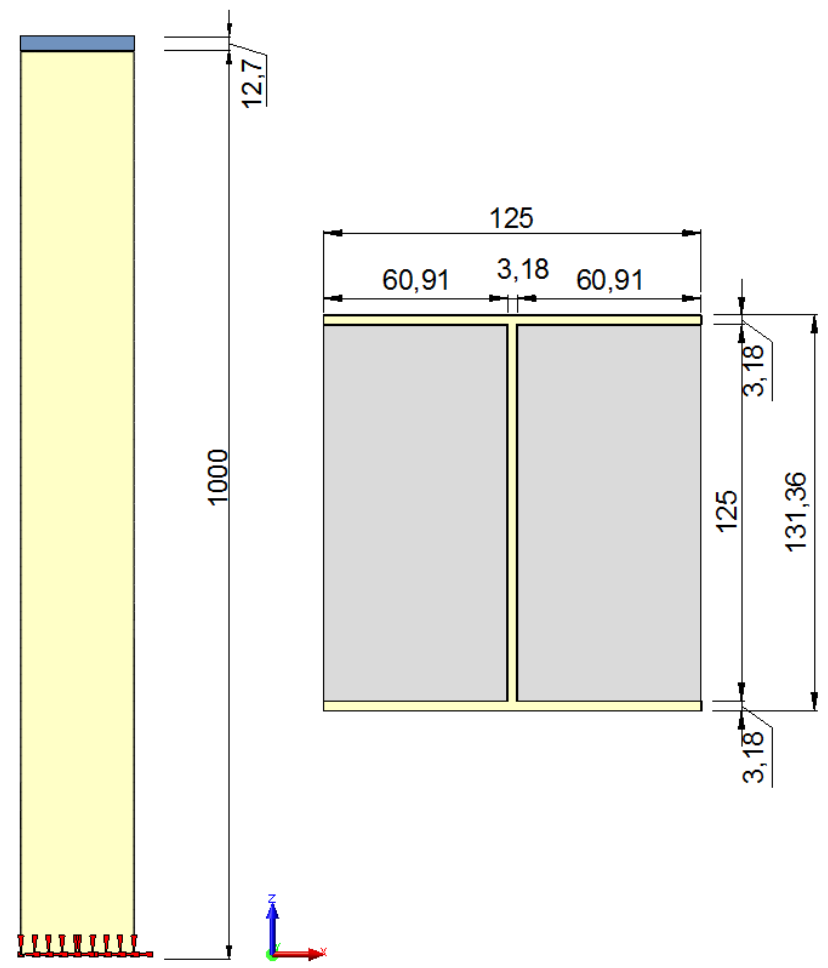

Figura 5.5 - Dimensões do Modelo em mm

Como condições de contorno para todos os nós da base, foram restringidas suas translações em $\mathrm{x}, \mathrm{y}$, e z, resultando assim em um engaste, já que se trata de elementos finitos sólidos que não possui graus de liberdade de rotação.

Esta geometria foi considerada para as três configurações de propostas no programa experimental:

1. Modelo 1 - Armadura convencional com vergalhões;

2. Modelo 2 - Armadura na forma de tela de aço soldada;

3. Modelo 3 - Sem armaduras na forma de barras, mas com a utilização de concreto com fibras de aço. 


\section{Elemento finito}

Foram utilizados elementos finitos sólidos, tanto para simulação do perfil metálico quanto do concreto entre as mesas do perfil. Da biblioteca de elementos finitos do software DIANA ${ }^{\circledR}$ v. 9.4.4, escolheu-se o elemento sólido HX24L. Trata-se de um elemento isoparamétrico com oito nós (Figura 5.6). Este elemento faz uma aproximação da distribuição de deformação e de tensões sobre o volume do elemento. Baseia-se na interpolação linear e de integração de Gauss.

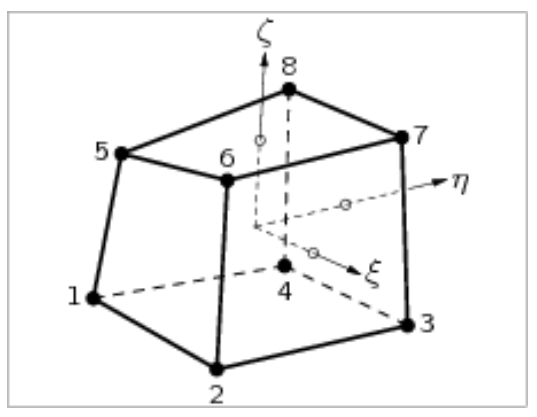

Figura 5.6 - Elemento finito HX24L. Adaptado DIANA, 2012

Ressalta-se que foi avaliada a possibilidade de utilização de um elemento com interpolação quadrática, uma vez que este poderia representar de maneira mais adequada o campo de tensões e deformações do modelo. Entretanto, as simulações numéricas com este elemento requereram grande esforço computacional e tempo de processamento. Além disso, os resultados obtidos pela simulação com o elemento de interpolação linear para o comportamento força vs. deslocamento e o campo de tensões foram bastante próximos aos obtidos pela simulação utilizando o elemento de interpolação quadrática.

Para os modelos cujas configurações apresentam armaduras em forma de vergalhões ou telas de aço (modelos 1 e 2), estas foram representadas por barras embutidas no concreto (Embedded reinforcements). Essa barra não é um elemento finito com graus de liberdade próprios e apenas altera a rigidez dos elementos onde ela está inserida, implicando na hipótese de aderência perfeita entre a barra e a matriz.

\section{Malha de elementos finitos}

A malha de elementos finitos é algo relevante para a resposta do modelo numérico, pois a adequada discretização da estrutura é fundamental para a precisão dos resultados e para a agilidade do processamento.

Neste sentido buscou-se a utilização de elementos finitos sólidos com as três dimensões iguais. Entretanto, para a representação do perfil metálico isto não foi possível, 
devido à pequena espessura da chapa metálica. A utilização de elementos de casca para representação do perfil metálico não é viável, uma vez que não haveria compatibilidade entre os graus de liberdade dos nós dos elementos finitos na interface perfil metálico-concreto.

Foi realizada uma análise da influência da malha de elementos finitos nos resultados de deslocamentos nodais. A Figura 5.7 apresenta a seção transversal discretizada de acordo com três malhas de elementos finitos. Foi realizada uma análise linear aplicando-se uma força centrada no pilar e observou-se que a diferença entre os deslocamentos no eixo longitudinal do pilar, comparando-se as malhas 2 e 3, foi de no máximo $0,10 \%$. Desta forma, adotou-se a malha 2 como malha ideal para representar o problema, ficando a malha adlotada com 9000 elementos e 14544 nós.

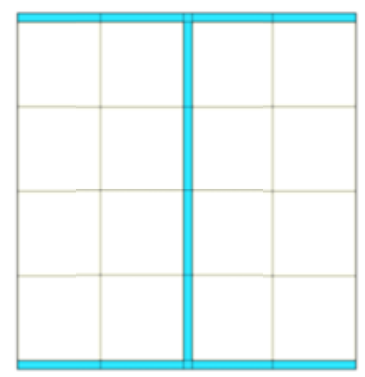

Malha 1

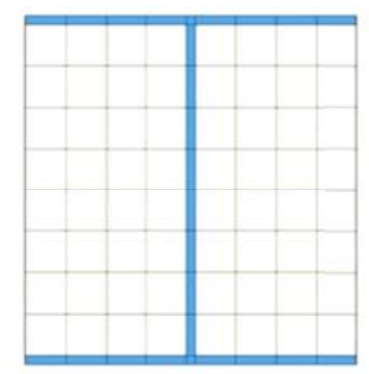

Malha 2

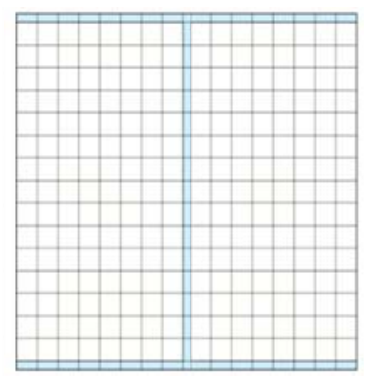

Malha 3

Figura 5.7 - Malha de elementos finitos

\section{Relação constitutiva dos materiais}

Para o aço, tanto do perfil como da armadura, foi adotado o comportamento elastoplástico perfeito (Figura 5.8) e critério de plastificação de Von Mises.

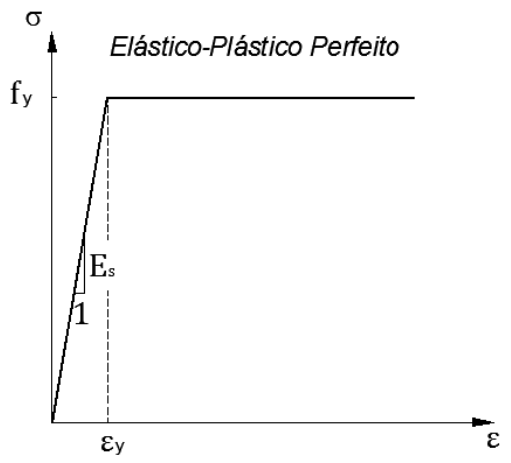

Figura 5.8 - Comportamento elasto-plastico

Para as análises preliminares foram considerados os valores recomendados pelas normas brasileiras para o módulo de elasticidade, e resistência ao escoamento de $250 \mathrm{MPa}$ e $500 \mathrm{MPa}$ para o aço do perfil e da armadura, respectivamente. 
Nas simulações numéricas de pilares mistos parcialmente revestidos, para representar o concreto optou-se pela abordagem de fissuração distribuída, mais especificamente o modelo com fissuração fixa baseado na Deformação Total (Total Strain Fixed Crack Model). Para este modelo foi necessário informar as propriedades básicas do material elástico linear (módulo de elasticidade e coeficiente de Poisson) e definir o comportamento à tração, cisalhamento e compressão.

$\mathrm{Na}$ análise preliminar as propriedades elásticas do material foram estimadas segundo as equações (3.41) e (3.44) apresentadas no Capítulo 3.

Para o comportamento do concreto à tração foi considerada uma curva tensãodeformação exponencial (Figura 5.9 - (a)). Esta curva é baseada na resistência à tração $\left(f_{t}\right)$, energia de fraturamento à tração do concreto $\left(G_{f}^{I}\right)$ e largura de banda de fissuração $(h)$. Para o comportamento do concreto à compressão foi considerada uma curva tensão-deformação parabólica disponível no pacote computacional DIANA ${ }^{\circledR}$ v. 9.4 .4 (Figura 5.9 - (b)). Esta é baseada na resistência a compressão $\left(f_{c}\right)$ energia de fraturamento a compressão do concreto $\left(G_{c}\right)$ e na largura de banda de fissuração $(h)$. A largura de banda neste caso equivale a 13,33 $\mathrm{mm}$.

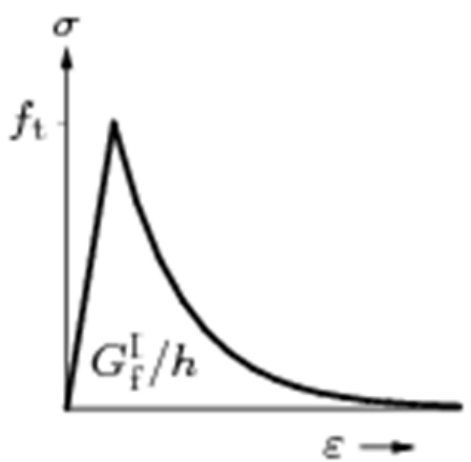

(a)

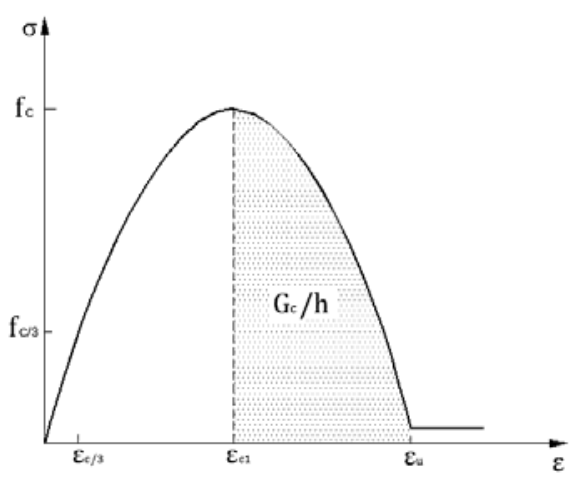

(b)

Figura 5.9 - (a) Modelo de amolecimento à tração; (b) Curva tensão-deformação do concreto a compressão uniaxial. Adaptado DIANA, 2012

Para as análises preliminares, os valores de resistência à compressão considerados foram 25, 50 e $80 \mathrm{MPa}$. Já os valores de energia de fraturamento à tração e à compressão foram estimados conforme as equações apresentadas no item 3.3.3 do Capítulo 3.

O comportamento do concreto ao cisalhamento está relacionado à transferência de tensão de cisalhamento através da fissura. Em geral, após o processo de fissuração no concreto haverá a transferência de parte das tensões cisalhantes por meio do engrenamento dos agregados, atrito e efeito pino das armaduras; desta forma, podem-se adotar valores 
intermediários para o fator $\beta$. Foi realizada uma análise da influência deste parâmetro para o modelo proposto e observou-se que os resultados não são influenciados pelo parâmetro, provavelmente por não haver tensões cisalhantes significativas. Admitiu-se $\beta$ constante com o valor de 0,5 para todas as simulações numéricas.

Outro aspecto considerado foi o comportamento biaxial do concreto. Após a fissuração, o concreto paralelo à direção da fissura ainda é capaz de resistir às tensões. Entretanto, as fissuras causam dano ao concreto, de modo que essas grandes deformações de tração perpendiculares à direção principal de compressão reduzem a resistência do concreto à compressão. Desta forma, para levar em conta este efeito considerou-se o modelo proposto por Vecchio e Collins (1993), disponível na biblioteca do DIANA ${ }^{\circledR}$. A Tabela 5.4 apresenta um exemplo de especificação do modelo constitutivo para o concreto.

Tabela 5.4- Exemplo de Especificação do modelo constitutivo para o concreto

\begin{tabular}{ll}
\hline $\begin{array}{l}\text { Relação constitutiva do material concreto } \\
\text { Regime Elástico linear }\end{array}$ & Comandos no DIANA ${ }^{(R)}$ \\
Módulo de elasticidade & YOUNG $36760 \mathrm{MPa}$ \\
Coeficiente de Possoin & POISON 0,2 \\
Regime não linear & \\
Total Strain Crack Models & TOTCRK FIXED \\
Comportamento a Tração - Diagrama exponencial & TENCRV EXPONE \\
Resistência à tração & TENSTR 4,093 MPa \\
Energia de Fraturamento $\left(G_{f}\right)$ & GF1 0,1027 MPa \\
Largura de banda & CRACKB $13,35 \mathrm{~mm}$ \\
Comportamento à compressão - Diagrama Parábola & COMCRV PARABO \\
Resistência à compressão & COMSTR $50 \mathrm{MPa}$ \\
Energia de Fraturamento $\left(G_{c}\right)$ & GC 1,027 MPa \\
Retenção de cisalhamento constante & SHRCRV CONSTA \\
Fator de retenção ao cisalhamento $(\beta)$ & BETA 0,5 \\
Modelo proposto por Vecchio e Collins & REDCRV VC1993 \\
\hline
\end{tabular}

\subsubsection{Estratégia de solução e critérios de convergência}

A estratégia de solução adotada foi a Quase-Newton (ou Secante), com critério de convergência em energia. A tolerância adotada foi de $10^{-2}$. Fez-se uso do algoritmo Line Search para redução do tempo de processamento. 
O deslocamento imposto foi aplicado em até 25 passos de $0,25 \mathrm{~mm}$. Como critério de parada considerou-se a perda de convergência do modelo.

\subsubsection{Resultados da Análise preliminar}

\section{Influência da energia de fraturamento à compressão}

Como foi apresentada no Capítulo 3, a energia de fraturamento à compressão pode ser estimada como sendo de 50 a 100 vezes o valor da energia de fraturamento à tração do concreto estudado. Também se pode estimá-la como sendo a área pós-pico sob a curva tensão x deformação do concreto, como indicado na Figura 5.9 - (b). Os valores de energia de fraturamento à compressão obtidos por meio destas metodologias são muito diferentes entre si. A fim de avaliar a influência destes valores nas simulações numéricas propõem-se os modelos Tabela 5.5.

Estas análises foram realizadas para o modelo 1, o qual possui armaduras convencionais como recomendadas pela ABNT - NBR 8800:2008, variando-se apenas o valor da energia de fraturamento à compressão do concreto.

Tabela 5.5 - Avaliação da influência da energia de fraturamento à compressão

\section{Estimativa da energia de fraturamento à compressão}

Modelo 1A

Área pós-pico sob a curva tensão x deformação proposta pelo EUROCODE 2 (1992)

Modelo $1 \mathrm{~B}$

50 vezes a energia de fraturamento a tração

Modelo 1C

100 vezes a energia de fraturamento a tração

A Figura 5.10 apresenta o comportamento força vs. deslocamento obtido para o Modelo 1, segundo os modelos propostos. 


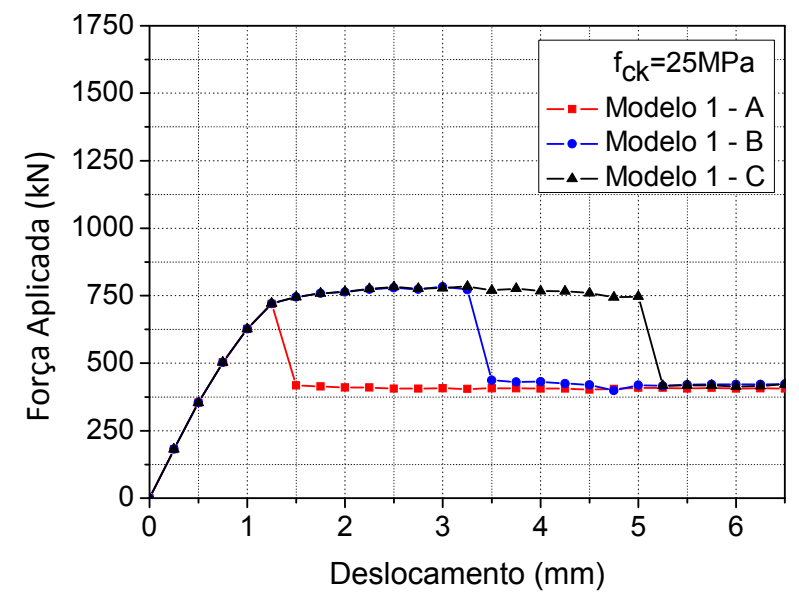

(a)

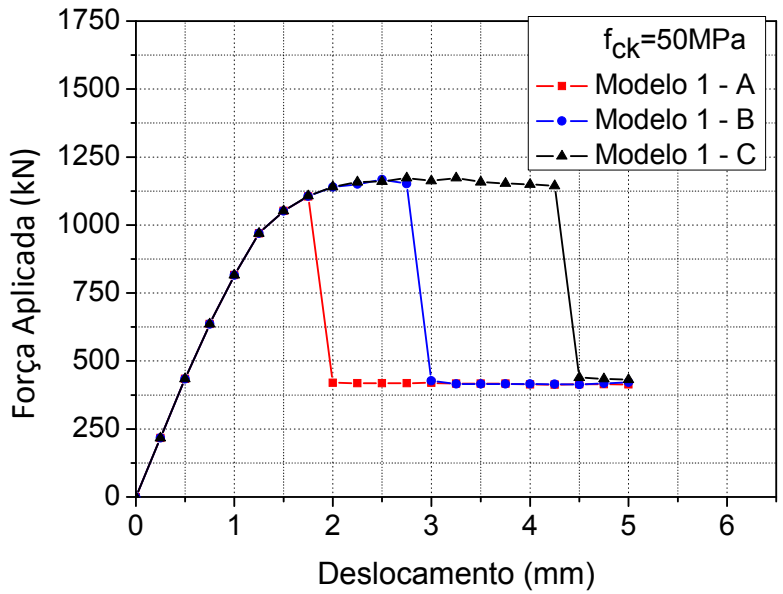

(b)

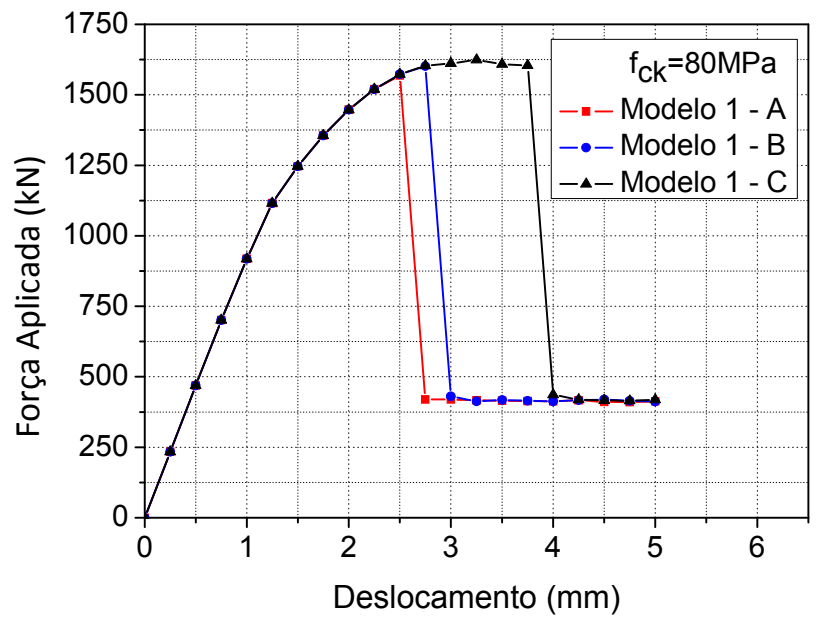

(c)

Figura 5.10 - Curva Força Aplicada x Deslocamento para diferentes valores de energia de fraturamento

Para todos os valores de resistência à compressão do concreto, foi observado que a resistência máxima do pilar atinge valores próximos independente do valor de energia de fraturamento à compressão adotada. Entretanto, percebe-se que quanto maior a energia fraturamento à compressão adotada, maiores são os deslocamentos finais da estrutura, resultando em maior ductilidade da estrutura. Graficamente isto é representado pelos patamares nas curvas força vs. deslocamento para os Modelos 1B e 1C.

Ao comparar os resultados obtidos para os Modelos 1A e Modelo 1B nota-se que, para os valores de resistência à compressão do concreto de $25 \mathrm{MPa}$ e $50 \mathrm{MPa}$, há um aumento de $300 \%$ e $143 \%$, respectivamente, nos deslocamentos finais do modelo numérico, enquanto que para os modelos com a resistência à compressão de $80 \mathrm{MPa}$ este aumento foi de $50 \%$, 
indicando maior sensibilidade à variação da energia de fraturamento à compressão, nos concretos de menores resistências.

Nota-se que para um dado valor de resistência à compressão há uma faixa de valores de energia de fraturamento que modifica os resultados obtidos pela simulação numérica. De modo que para uma grande resistência, por exemplo, $80 \mathrm{MPa}$, a variação do valor da energia de fraturamento à compressão em uma faixa de aproximadamente 10 a 100 vezes o valor da energia de fraturamento à compressão causa mudanças pouco expressivas.

Observa-se ainda que, para simulação de pilares mistos parcialmente revestidos submetidos à compressão centrada, a energia de fraturamento à compressão define o ponto a partir do qual há queda na capacidade resistente do elemento.

Independente do valor de energia de fraturamento à compressão adotado, o comportamento foi coerente com o esperado, isto é, quanto maior a resistência do material menor a ductilidade. Contudo, o elevado deslocamento apresentado previamente à ruptura, acredita-se não ser compatível com o comportamento esperado para o concreto. Desta forma, optou-se por estimar a energia de fraturamento à compressão por meio da área pós-pico sob a curva tensão x deformação proposta pelo EUROCODE 2 (1992).

\section{Comportamento estrutural global}

A Figura 5.11 apresenta os resultados obtidos na simulação numérica exploratória para o comportamento dos pilares misto parcialmente revestidos submetidos à compressão axial utilizando concreto com resistência a compressão de $50 \mathrm{MPa}$ nas três configurações propostas.

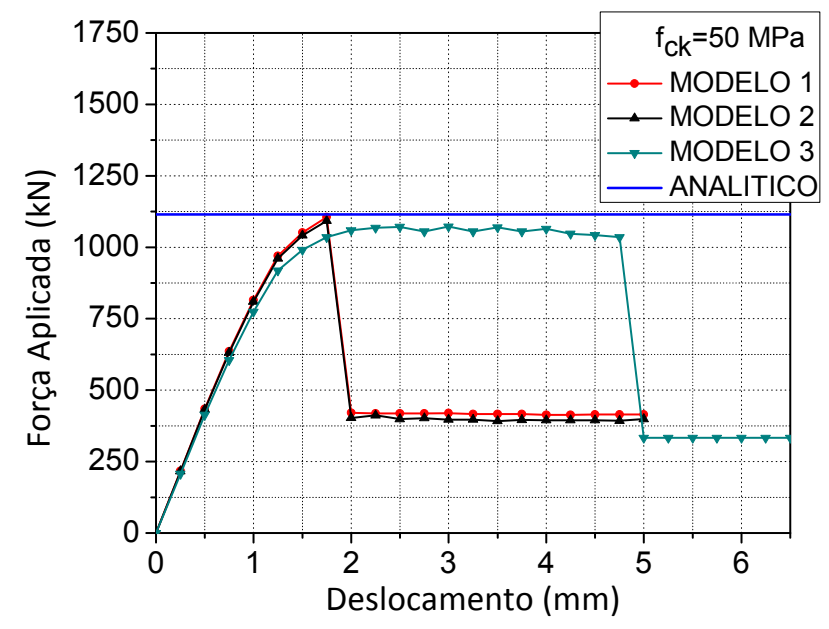

Figura 5.11 - Curva força vs. deslocamento - Pilar misto com concreto de $\mathrm{f}_{\mathrm{ck}}=50 \mathrm{MPa}$ 
As curvas força vs. deslocamento indicam que os comportamentos observados para os Modelos 1 e 2 são similares, uma vez que foi utilizada a mesma taxa de aço.

Ressalta-se ainda que a capacidade resistente obtida para os Modelos 1 e 2 é coerente com o valor estimado analiticamente. Para o pilar misto que utiliza concreto com resistência de $50 \mathrm{MPa}$, o Modelo 1 apresenta valor numérico $0,95 \%$ menor que o valor estimado e para o Modelo 2 ele é 2,04\% menor.

Entretanto, a adição de fibras ao concreto modifica o comportamento global do pilar misto, resultando em maior ductilidade e maior deformação antes do colapso. Além disso, a força máxima resistida quando se utiliza concreto com fibras é 3,83\% menor que o valor estimado.

A Figura 5.12 apresenta o panorama de fissurações no concreto. Pode-se observar que para as condições de contorno adotadas nas análises preliminares a fissuração ocorreu de modo intenso na base do pilar, indicando uma possível ruptura neste ponto.

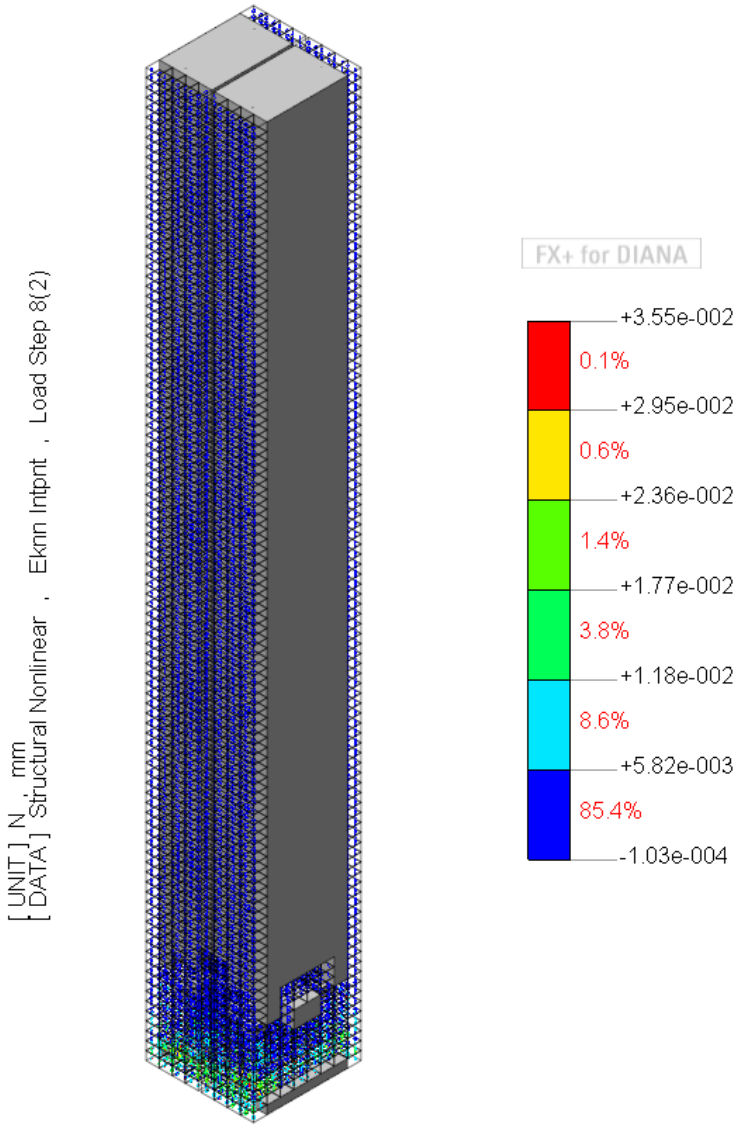

Figura 5.12 - Panorama de fissuração no concreto

No programa experimental não foi observada ruptura ou grande fissuração na base, e no pós-pico também não houve uma queda de resistência tão rápida como indicado na Figura 
5.11. Deste modo optou-se, para as Análises Definitivas, em fazer a alteração das condições de contorno da base, pois provavelmente durante o ensaio o confinamento conferido pela máquina à base do pilar não foi o suficiente para promover o engastamento perfeito desta.

\subsubsection{Análises Definitivas}

\subsubsection{Hipóteses adotadas}

\section{Condições de contorno}

Nas análises definitivas mantiveram-se as mesmas características geométricas, alterando-se apenas as condições de contorno da base. Para diminuir as restrições que geram concentração de tensões e reproduzir as condições de vinculação do ensaio experimental foram restritas, em todos os nós, as translações em z, e apenas para os nós da alma do perfil restritas as translações em x e y, na região da base, como indicado na Figura 5.13.

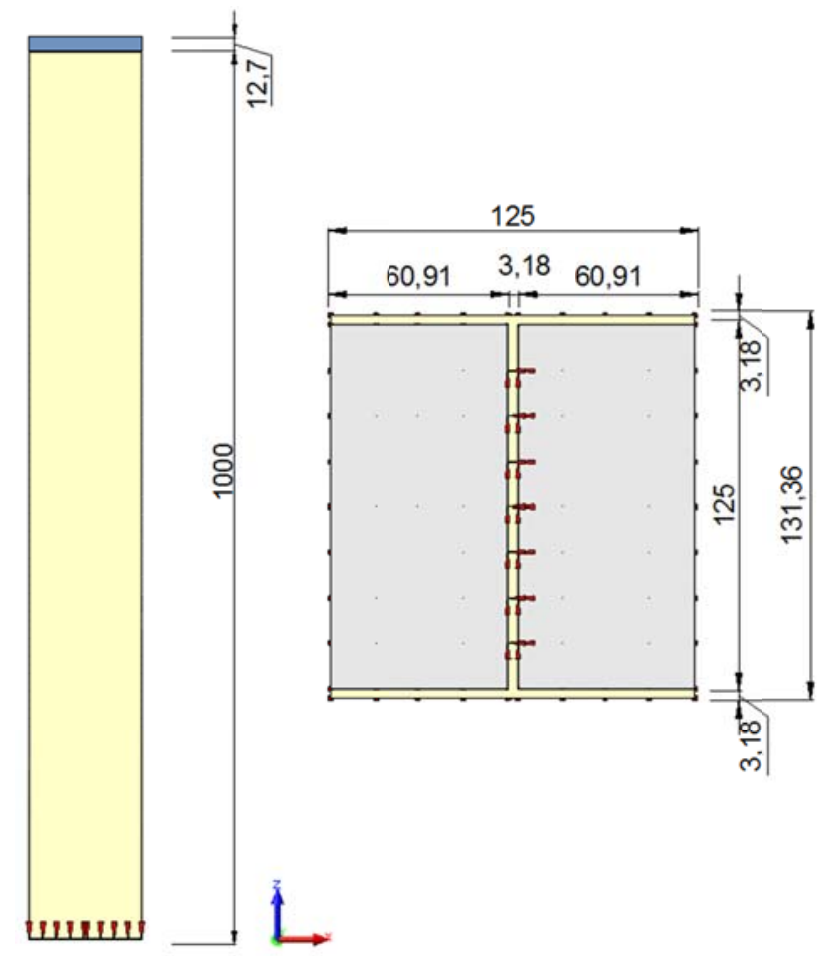

Figura 5.13 - Condições de contorno nas análises definitivas

A vinculação na extremidade superior manteve-se livre, uma vez que os pilares apresentaram deslocamentos laterais no topo nos ensaios experimentais. 
Em uma primeira análise o deslocamento foi aplicado centrado no pilar, porém o valor da força máxima da simulação numérica resultou aproximadamente $30 \%$ superior ao valor experimental do pilar simulado.

A fim de reduzir o valor da força máxima obtida com o modelo numérico foi imposto um valor de excentricidade ao carregamento. Esta excentricidade foi considerada como uma excentricidade acidental, fruto provavelmente de algum desvio no posicionamento do modelo experimental.

\section{Malha e elemento finito}

Como a análise preliminar apresentou resultados satisfatórios utilizou-se o mesmo elemento finito para as análises definitivas. O elemento sólido HX24L da biblioteca de elementos finitos do DIANA ${ }^{\circledR}$ v. 9.4.4 é um elemento isoparamétrico com oito nós e aproximação linear.

Para a malha de elementos finitos também foi mantida a discretização assumida como ideal pelas análises preliminares (Figura 5.14). Apenas para região de introdução do carregamento houve um refinamento da malha para possibilitar a aplicação de uma excentricidade acidental do carregamento, resultando em uma malha com 11000 elementos e 17170 nós para os modelos 1 e 2.

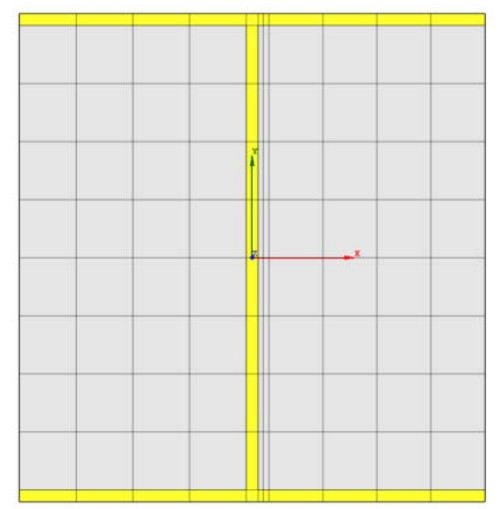

Figura 5.14 - Vista da seção transversal do pilar misto

Na Figura 5.15 são demonstrados os componentes do modelo numérico separadamente para o modelo 1 (configuração com armadura convencional). Para as barras de armadura foram utilizadas barras embutidas em elementos finitos (Bar reinforcement). No modelo 2 os componentes são similares apenas substituindo a armadura convencional pela tela de aço soldada. 
Para o modelo 3 foi aplicada uma excentricidade proposital no carregamento (M3-E) e desta forma utilizou-se uma malha de elementos finitos com discretização especial nesta região resultando em 13200 elementos e 18548 nós. Esta mesma malha foi utilizada para as análises paramétricas.

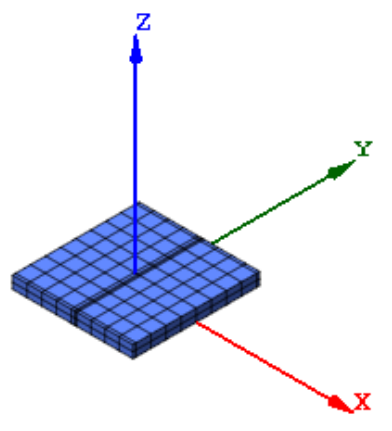

(a)

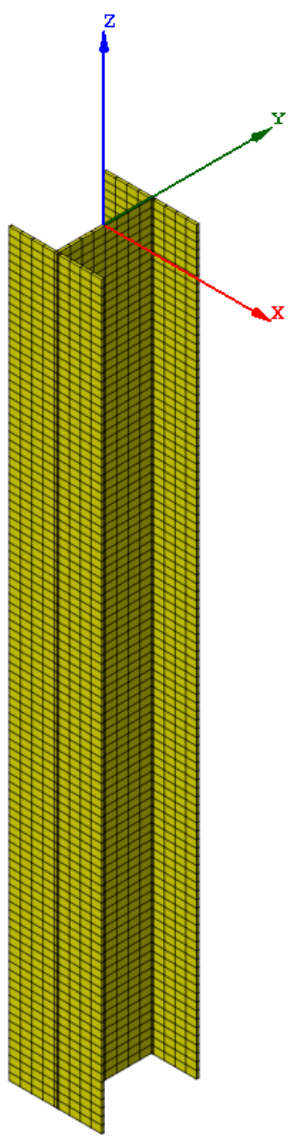

(b)

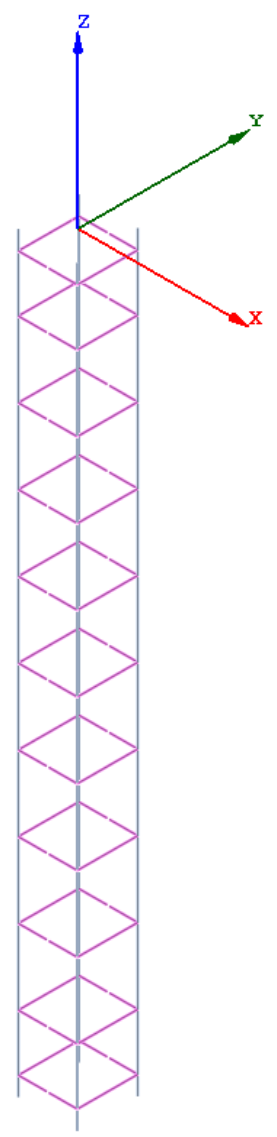

(c)

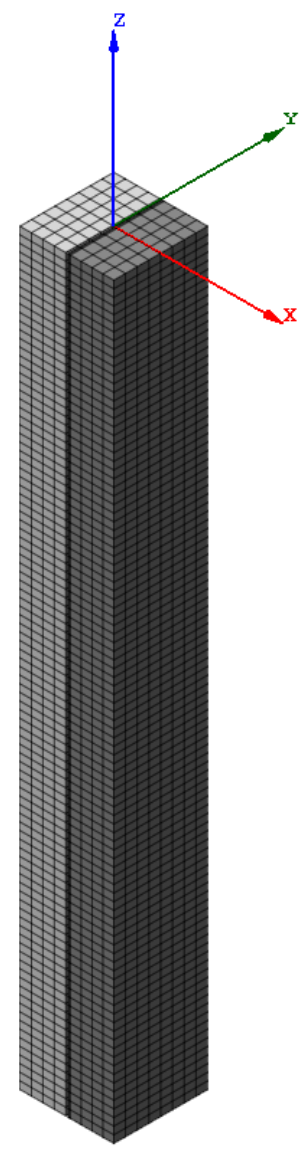

(d)

Figura 5.15 - Componentes do modelo numérico: (a) Chapa de topo; (b) Perfil metálico; (c) Armadura; (d) Blocos de concreto.

\section{Relação constitutiva dos materiais}

Não houve mudanças significativas nas relações constitutivas dos materiais para as análises definitivas. Para o aço que constitui o perfil metálico e as barras da armadura foi adotado um comportamento elástico-perfeito com critério de plastificação de Von Mises.

Para representar o comportamento do concreto foi adotado o modelo de fissuração distribuída com fissuração fixa baseado na deformação total (Total Strain fixed crack model) onde se utilizou uma curva exponencial para representar o amolecimento do material à tração e uma curva parabólica para representar o comportamento à compressão do material. 
Os dados de entrada solicitados pelo pacote computacional foram preenchidos com os dados obtidos nos ensaios de caracterização dos materiais. Apenas o valor da energia de fraturamento à compressão não pode ser obtido experimentalmente e foi calibrado a partir dos resultados obtidos para o comportamento estrutural global do pilar.

\subsubsection{Calibração do modelo numérico}

Os resultados experimentais do comportamento global do elemento estrutural representados pela curva força aplicada vs. encurtamento do pilar foram comparados com os resultados obtidos numericamente a fim de avaliar a representatividade do modelo numérico desenvolvido. Para se obter o encurtamento do pilar calculou-se a diferença dos deslocamentos entre dois nós, como ocorreu no ensaio experimental.

Como se verificou nas análises preliminares que o valor da energia de fraturamento à compressão define o ponto a partir do qual há a queda na capacidade resistente do elemento este parâmetro foi calibrado de modo a coincidir o início do trecho descendente da curva experimental com a numérica, resultando em um valor de $1,0 \mathrm{~N} . \mathrm{mm} / \mathrm{mm}$.

Outro parâmetro que necessitou ser calibrado foi a excentricidade acidental imposta no modelo numérico. Foram avaliadas excentricidades iguais a $3 \mathrm{~mm}, 4,5 \mathrm{~mm}$ e $5,5 \mathrm{~mm}$, sendo os resultados no comportamento global do elemento são apresentados na Figura 5.16.

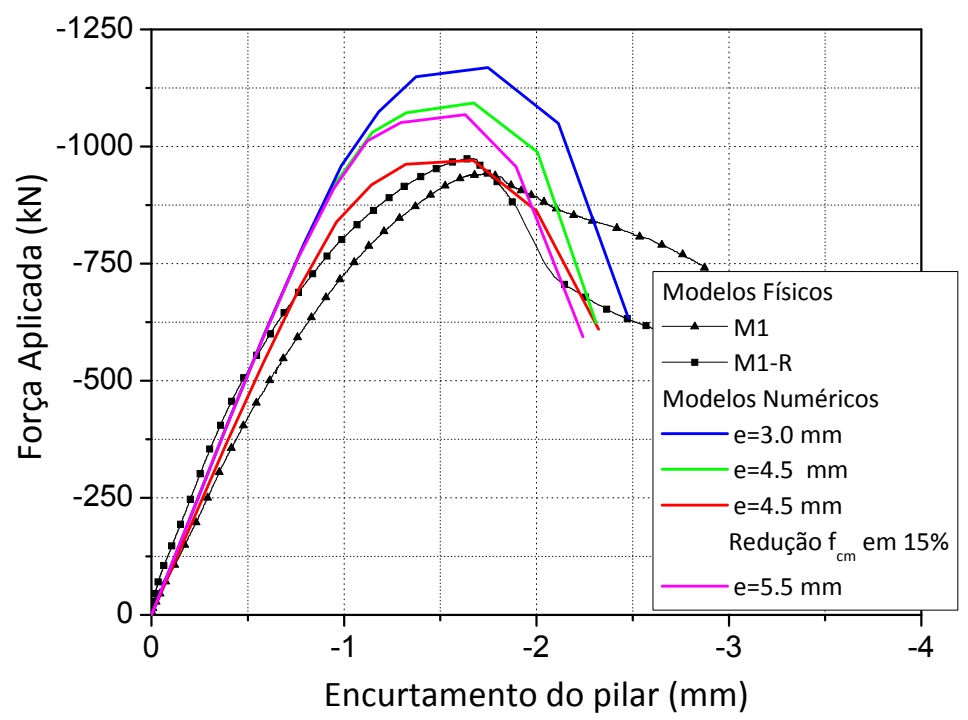

Figura 5.16 - Curva Força aplicada vs. Encurtamento do pilar para modelos físicos e numéricos

Observa-se no gráfico da Figura 5.16 que a introdução de excentricidades ao carregamento diminui significativamente o valor da capacidade resistente máxima do pilar 
misto. Nota-se ainda que mesmo para um valor de $5,5 \mathrm{~mm}$ de excentricidade não é possível reproduzir a curva Força Aplicada x Encurtamento do pilar experimental utilizando o modelo numérico. Neste contexto, propõe-se que as propriedades mecânicas do concreto obtidas por meio dos ensaios de caracterização sejam reduzidas, uma vez que as condições de cura e adensamento do concreto não são tão eficientes para o modelo físico de pilar misto quanto para os corpos-de-prova utilizados para caracterização. As pequenas dimensões da seção transversal do pilar misto e do espaçamento entre as barras de armadura dificultam o adensamento do material no estado fresco, prejudicando sua resistência final.

A partir desta calibração concluiu-se que o modelo numérico que melhor representa o comportamento estrutural obtido pelos ensaios experimentais possui como hipótese um valor de 4,5mm de excentricidade no carregamento axial e uma redução de $15 \%$ nas propriedades mecânicas do material. Cabe ressaltar que para os modelos onde não havia a armadura esta redução não foi efetuada, já que a ausência da armadura e a fluidez do concreto com fibras proporcionada pelo superplastificante adicionado auxiliaram no processo de adensamento.

\subsubsection{Resultados das análises definitivas}

\section{Força aplicada vs. encurtamento vertical}

A Figura 5.17 apresenta a curva força aplicada vs. encurtamento vertical para os modelos físicos M1 e M1-R e para o modelo numérico que busca representá-los. Observa-se boa correlação entre os resultados experimentais e numéricos, especialmente para a comparação com o modelo M1-R para o qual o pós-pico pode ser mais bem representado.

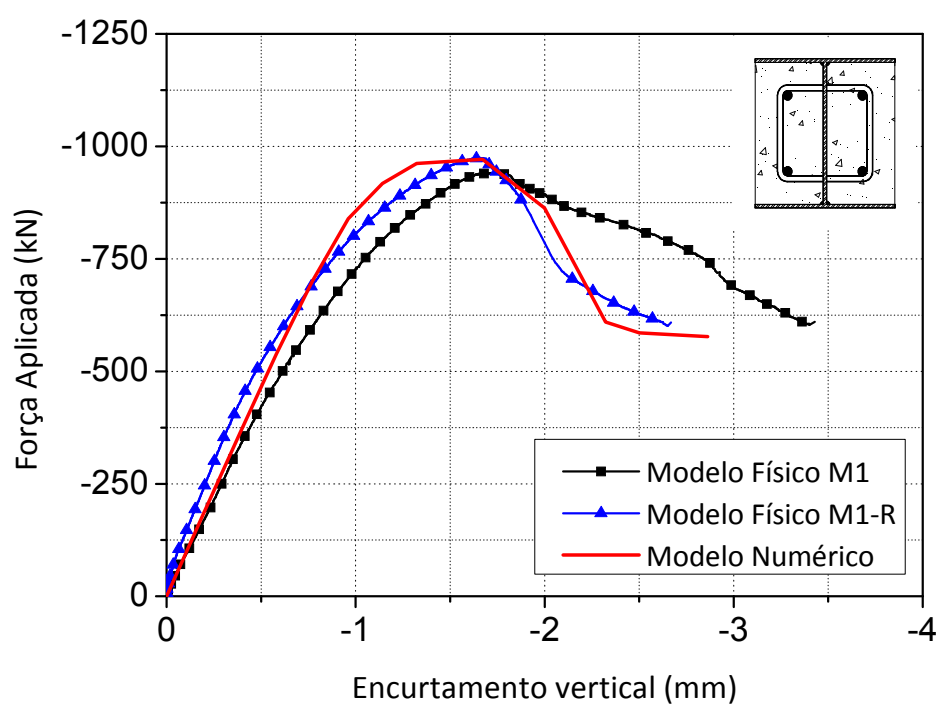

Figura 5.17 - Curva Força vs. Encurtamento vertical modelo 1 
Já para os modelos físicos M2 e M2-R onde as armaduras convencionais foram substituídas o por telas de aço a Figura 5.18 apresenta a comparação entre as curvas Força aplicada vs. Encurtamento vertical experimental e numérica. O modelo numérico não pode representar adequadamente o modelo físico M2, especialmente no que diz respeito à rigidez, isto pode ser explicado pelo fato deste modelo físico estar possivelmente submetido a uma excentricidade acidental no outro eixo (eixo de menor inércia).

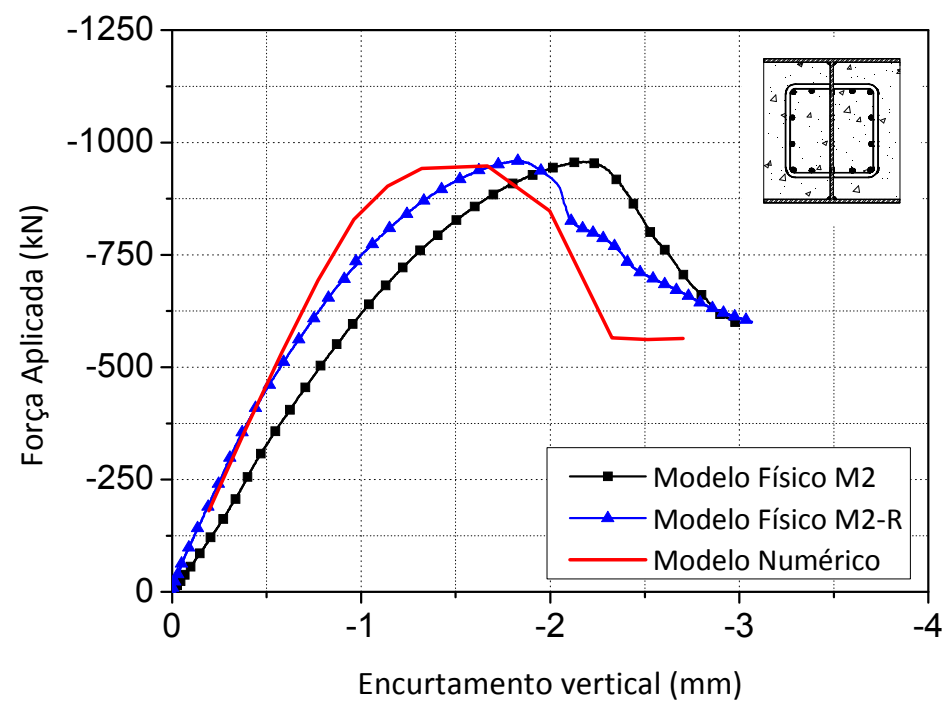

Figura 5.18 - Curva Força vs. Encurtamento vertical modelo 2

A Figura 5.19 apresenta a comparação entre os modelos experimental M3 e M3-E com o modelo numérico. Para o M3-E os resultados numéricos apresentaram correlação satisfatória com os resultados experimentais. Entretanto, o modelo M3 apresentou um comportamento distinto, como escorregamentos na direção do eixo de menor inércia ocasionados por alguma imperfeição geométrica ou de posicionamento na máquina que não puderam ser identificadas inviabilizando a sua representação via modelo de elementos finitos.

No gráfico da Figura 5.19 apresenta-se o modelo numérico que representaria o modelo M3 ideal, isto é um modelo de pilar misto parcialmente revestido com concreto com fibras com as características experimentais para um carregamento com valor de excentricidade acidental de 4,5 mm no eixo de maior inércia caso este não apresentasse imperfeições. Observa-se que a rigidez acompanharia o modelo M3-E e ficaria sensivelmente mais rígido que o modelo M3. 


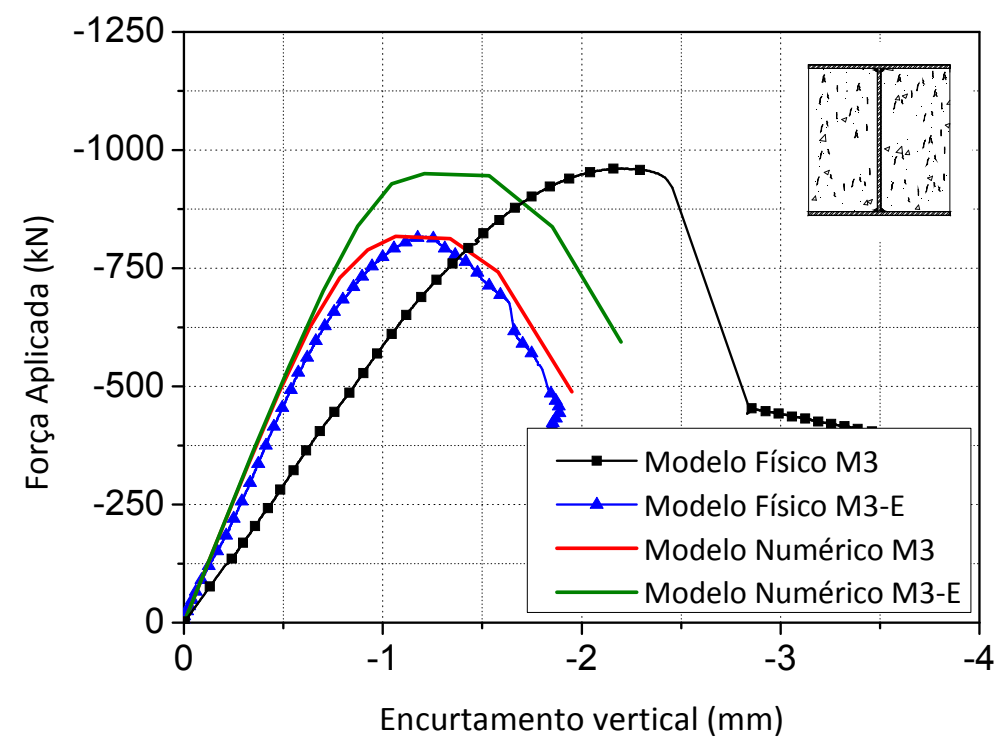

Figura 5.19 - Curva Força vs. Encurtamento vertical modelo 3

A Tabela 4.11 apresenta os resultados de força de pico obtidos na simulação numérica e a comparação com os valores obtidos nos ensaios experimentais.

Tabela 5.6 - Relação entre a força experimental e numérica para os pilares

\begin{tabular}{ccccc}
\hline Modelo & & $\mathbf{F}_{\mathbf{e x p}}$ & $\mathbf{F}_{\text {num }}$ & $\mathbf{F}_{\mathbf{e x p}} / \mathbf{F}_{\text {num }}$ \\
Modelo 1 & M1 & 943,00 & & 0,971 \\
& M1-R & 974,00 & 970,97 & 1,003 \\
Modelo 2 & M2 & 954,00 & & 1,006 \\
& M2-R & 950,00 & 948,33 & 1,002 \\
Modelo 3 & M3 & 961,00 & 949,84 & 1,012 \\
& M3-E & 816,00 & 817,01 & 1,001 \\
Média & & & & $\mathbf{0 , 9 9 8}$ \\
Desvio Padrão & & & & $\mathbf{0 , 0 1 4}$ \\
\hline
\end{tabular}

Os resultados numéricos mostraram-se muito próximos aos resultados experimentais. Em média os valores experimentais foram $0,2 \%$ inferiores aos obtidos por meio da simulação numérica. Apesar de em alguns casos o modelo numérico não representar com fidelidade o comportamento pós-pico dos pilares, a capacidade resistente pode ser estimada satisfatoriamente com a consideração da excentricidade acidental.

\section{Modo de ruptura}




\section{Modelo 1 e 2}

Os modelos 1 e 2 apresentaram comportamento bastante similar, como pode ser visto nas Figura 5.17 e Figura 5.18. Desta forma, para representar o modo de ruptura destes modelos serão apresentados o panorama de tensões principais e a fissuração do concreto apenas para o modelo 1 .

A Figura 5.20 apresenta a distribuição de tensões de Von Mises para o perfil metálico. Pode-se verificar que grande parte das mesas e a alma do perfil encontram-se com elevados valores de tensão, próximos ao valor da tensão de escoamento $(322.90 \mathrm{MPa})$, indicando o início da plastificação da seção, coerente com o observado experimentalmente.

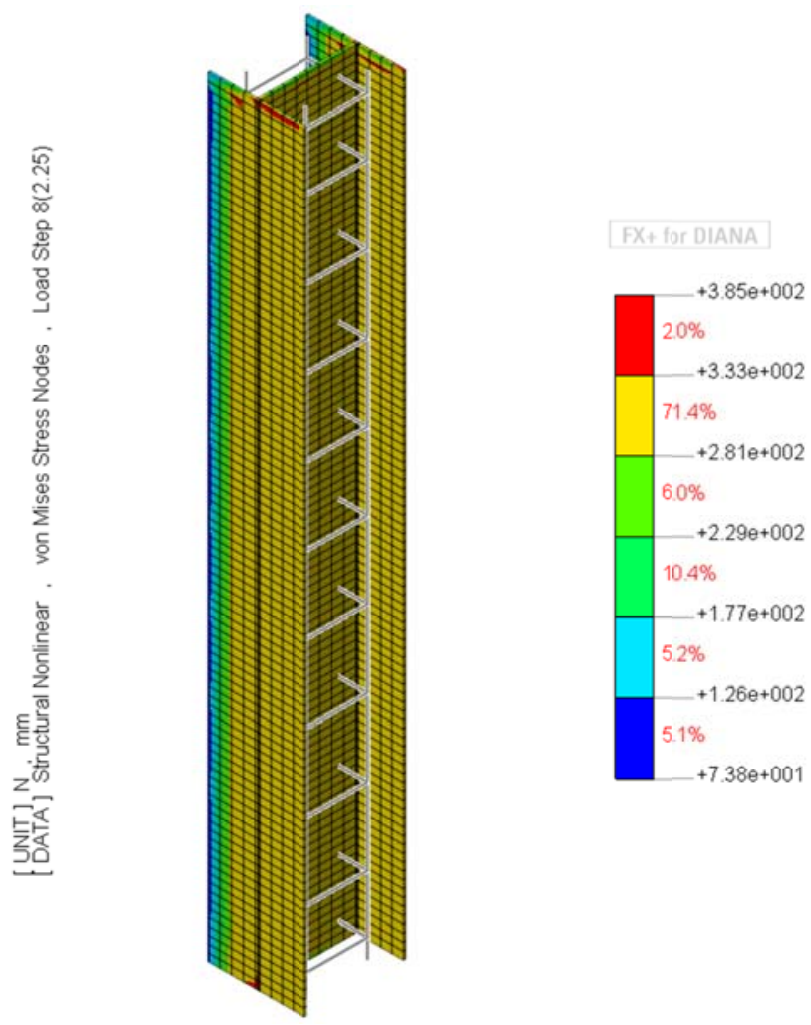

Figura 5.20 - Panorama de tensões de Von Mises para o perfil metálico no Modelo 1

As tensões principais no bloco de concreto referentes ao passo correspondente à força máxima do modelo são apresentadas nas Figura 5.21, Figura 5.22 e Figura 5.23. Nestas figuras, as tensões principais são mostradas por meio de gradiente de tensões, indicadas com (a), e também se apresenta a região do bloco de concreto onde as tensões excederam as de tração (ou compressão) do material, indicadas como (b). Para a Figura 5.21 ainda é mostrada a distribuição de fissuração. 

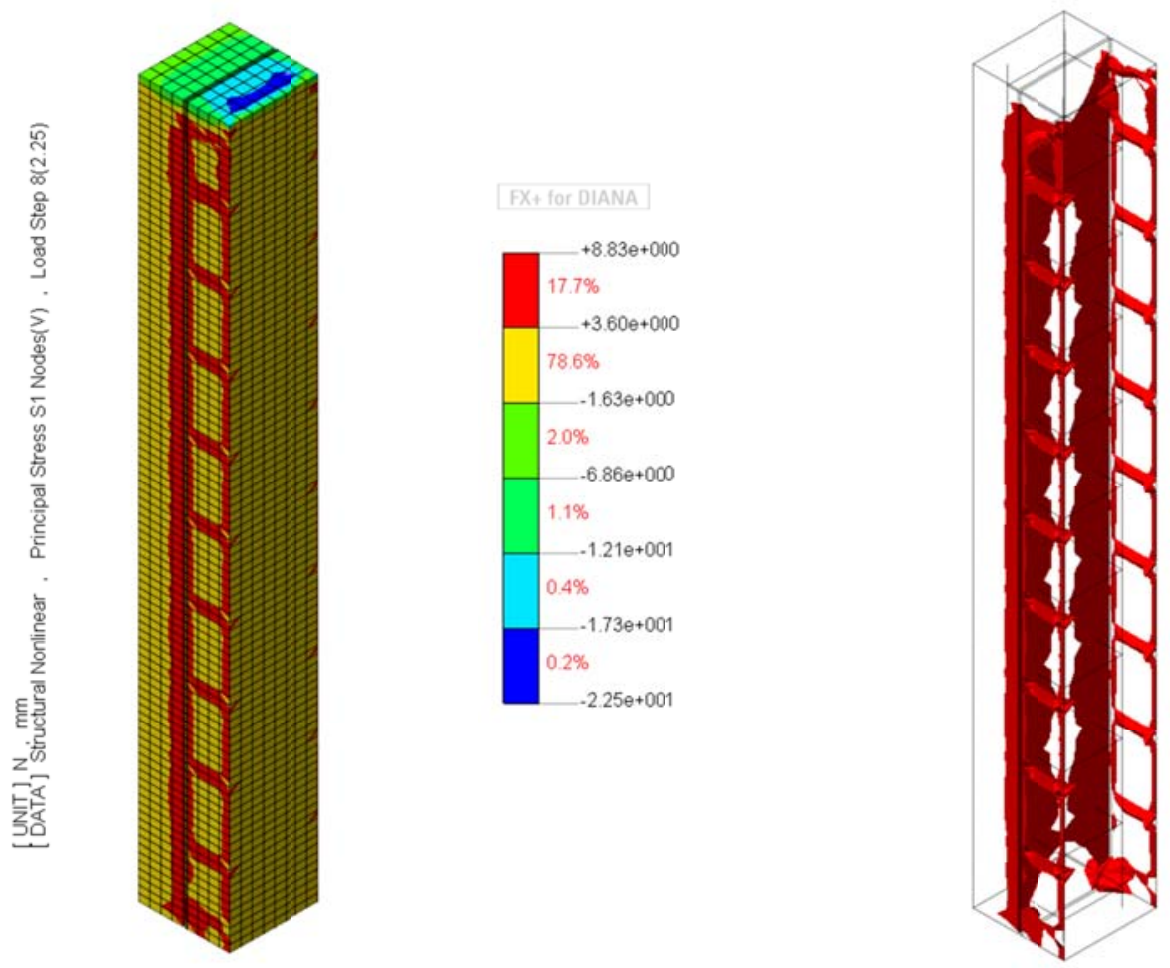

(a)

(b)
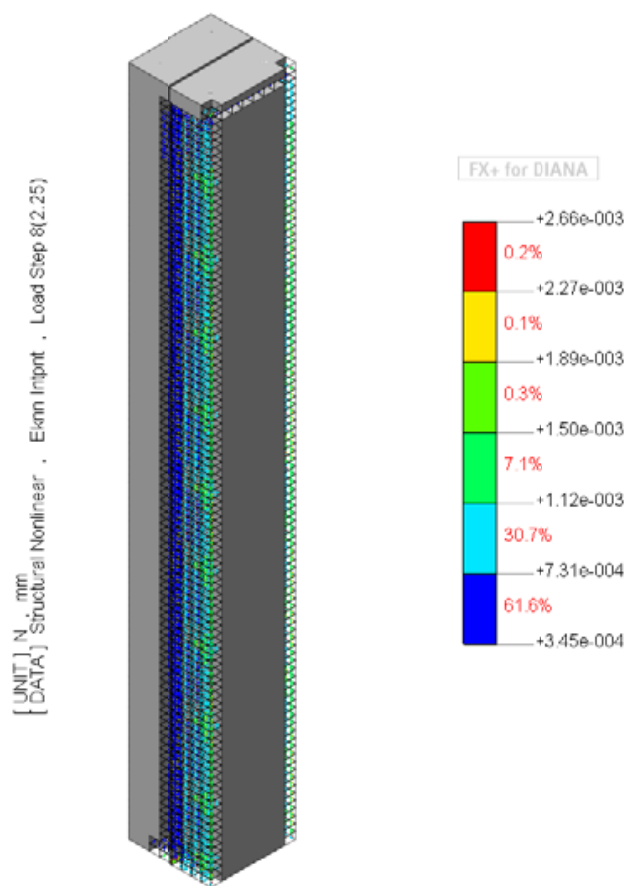

(c)

Figura 5.21 - (a) Panorama da tensão principal S1 no bloco de concreto; (b) Região do bloco onde a tensão S1 excedeu a tensão de tração no concreto; (c) Fissuração no concreto referente à força máxima no Modelo 1 


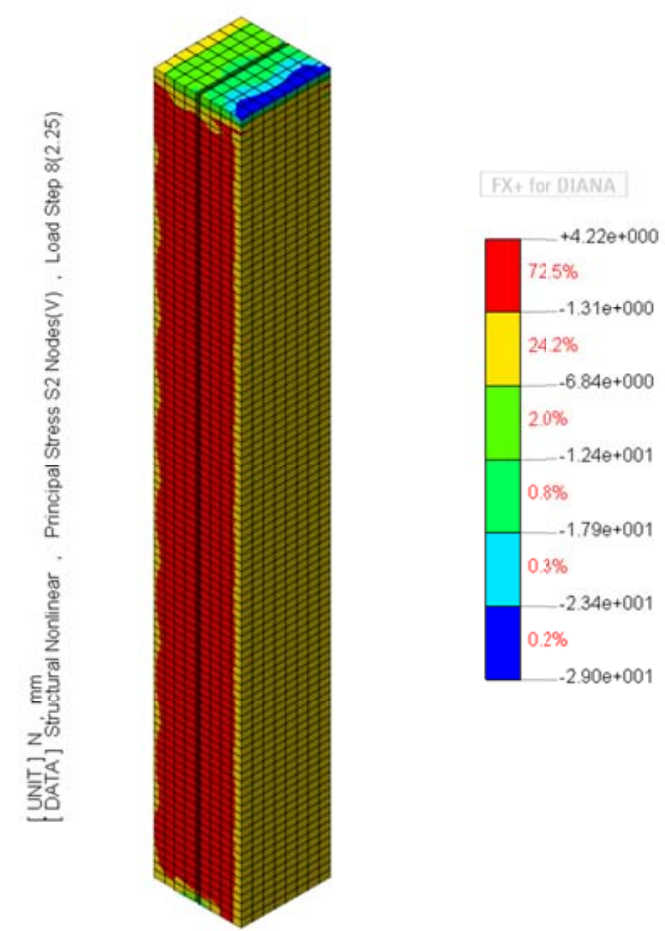

(a)

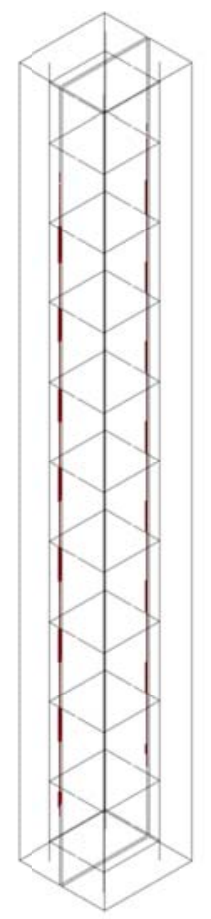

(b)

Figura 5.22 - (a) Panorama da tensão principal S2 no bloco de concreto; (b) Região do bloco onde a tensão S1 excedeu a tensão de tração resistente do concreto no Modelo 1.

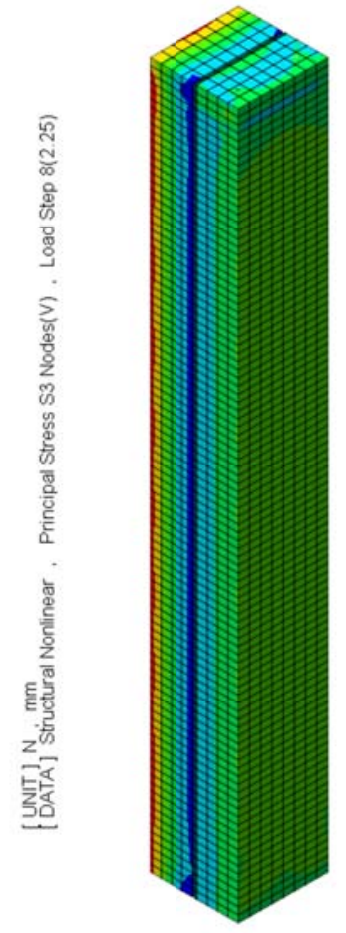

(a)

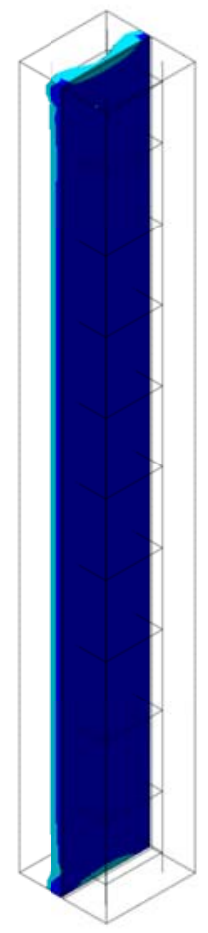

(b)

Figura 5.23 - (a) Panorama da tensão principal S3 no bloco de concreto; (b) Região do bloco onde a tensão S1 excedeu a tensão de compressão resistente do concreto no Modelo 1. 
A concentração de elevadas tensões de tração/compressão na região de concreto em contato com o perfil metálico (Figura 5.21, Figura 5.22 e Figura 5.23) é coerente com o aspecto da fissuração apresentado (Figura 5.21 - (c)). O mesmo padrão de fisssuração também pode ser observado nos modelos físicos, onde as fissuras, até a força máxima, se concentravam na interface aço- concreto.

Após a força máxima, no modelo numérico, há um aumento significativo da fissuração no concreto, de modo que a maior parte do bloco do concreto encontra-se em estado já fissurado o que também reproduz satisfatoriamente o modelo físico.

A Figura 5.24 apresenta as tensões nas armaduras para os modelos 1 e 2. Observa-se que para a força máxima, as barras longitudinais apresentam valores de tensão próximos dos valores da tensão de escoamento do aço da barra, enquanto as barras transversais apresentam níveis de tensões mais baixos.

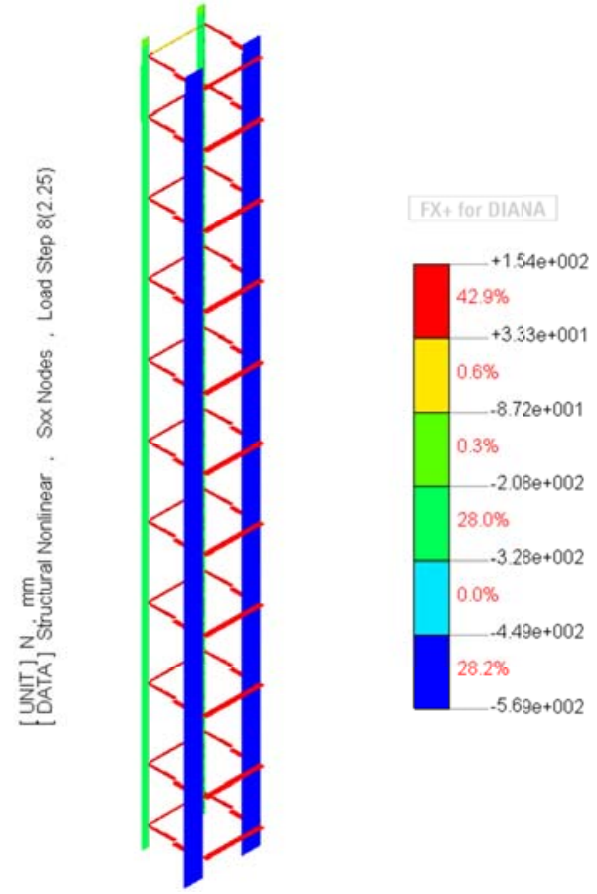

(a)

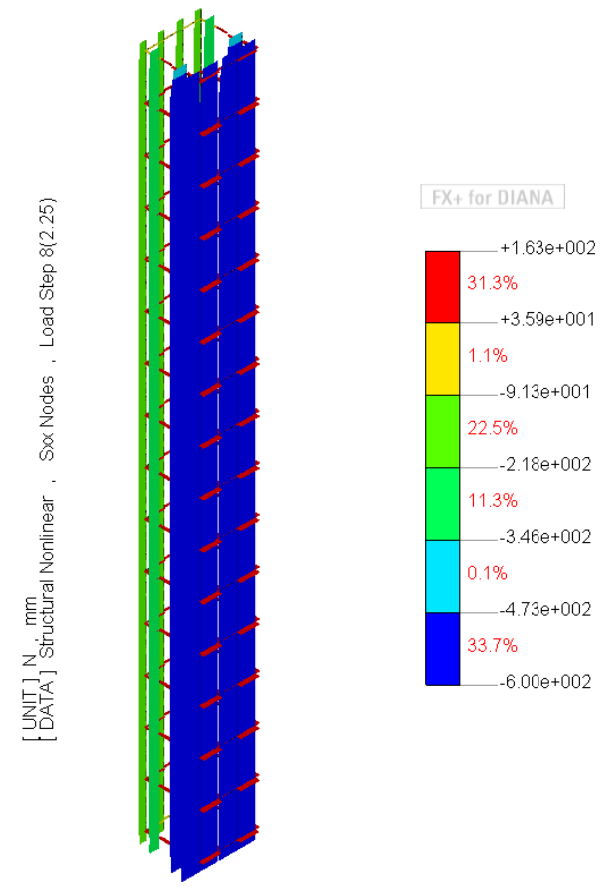

(b)

Figura 5.24 - Tensões na armadura (a) Modelo 1; (b) Modelo 2

\section{Modelo 3}

Para o modelo 3, que teve a força aplicada com excentricidade de $10 \mathrm{~mm}$, apresentamse as tensões de Von Mises para o perfil metálico na Figura 5.25. Novamente para a força máxima o perfil está submetido a elevados níveis de tensão, em especial na face mais comprimida do pilar misto, na qual ocorre a plastificação do perfil. 


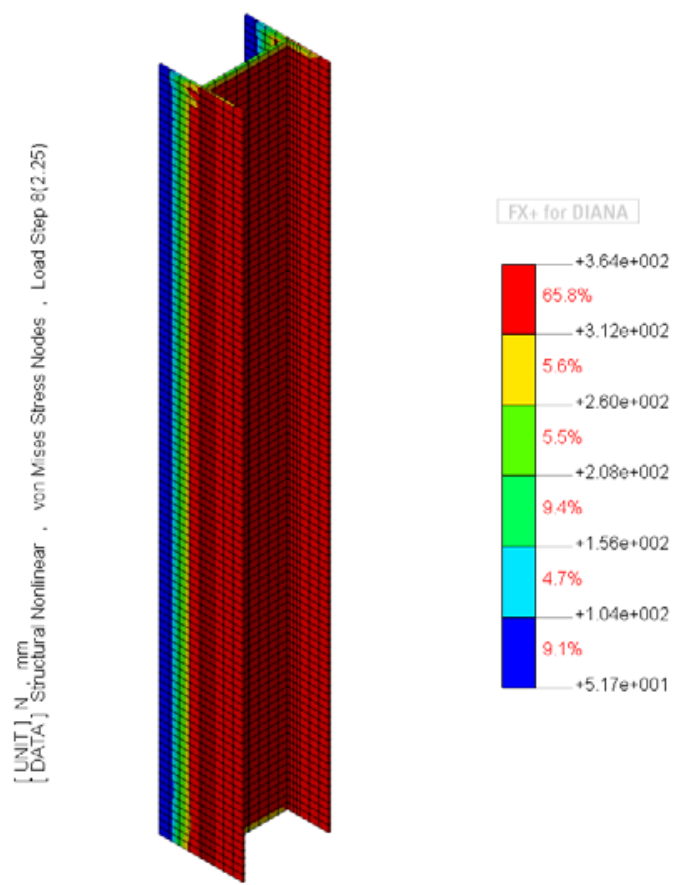

Figura 5.25 - Panorama de tensões de Von Mises para o perfil metálico no Modelo M3-E

As tensões principais no bloco de concreto para a força máxima do modelo 3 são apresentadas nas Figura 5.26; Figura 5.27 e Figura 5.28. Nestas figuras, mostram-se o gradiente de tensões, indicadas com (a), e também a região do bloco de concreto onde as tensões excederam as de tração (ou compressão) do material, indicadas como (b).

As tensões principais S1 indicam que as maiores tensões de tração estão localizadas no concreto adjacente às mesas do perfil metálico e em uma das faces expostas de concreto. Já as tensões de compressão que excederam a resistência do material estão localizadas no concreto da interface com a alma do perfil metálico.

O panorama de fissuração apresentado na Figura 5.26 é coerente com as concentrações de tensões apresentadas. Nota-se em uma das faces uma concentração de fissuras na extremidade superior do pilar compatível com a fissura de tração observada no modelo físico. 


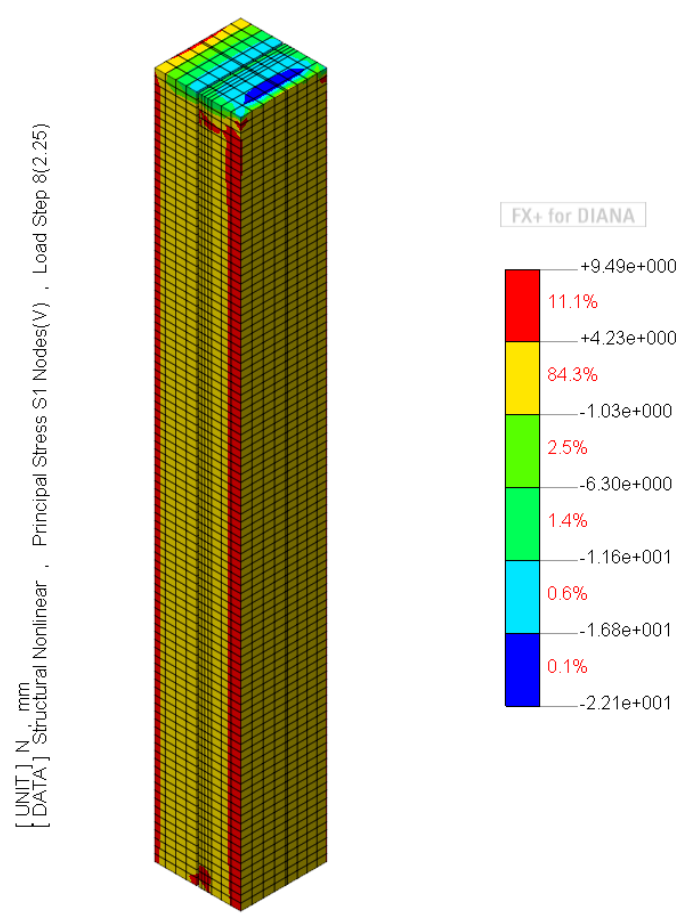

(a)

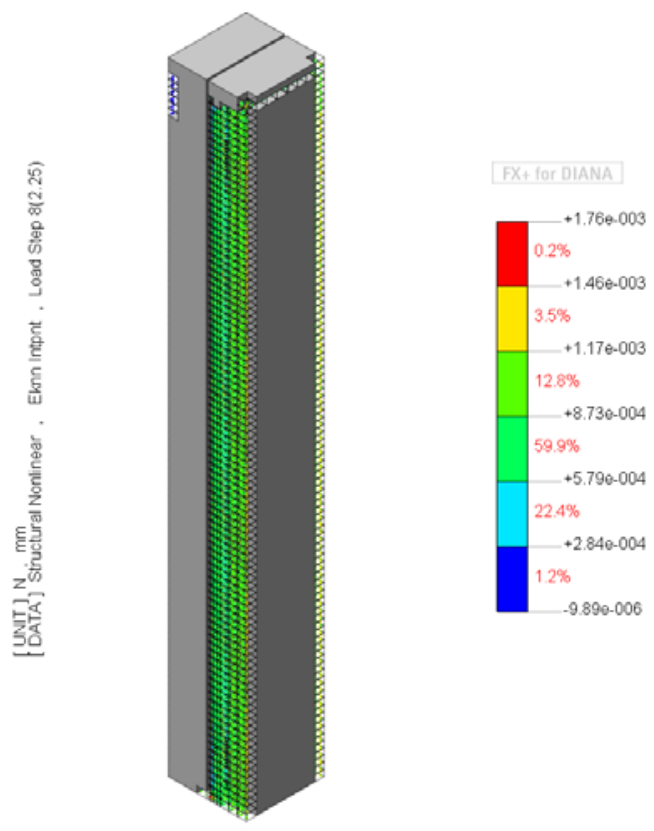

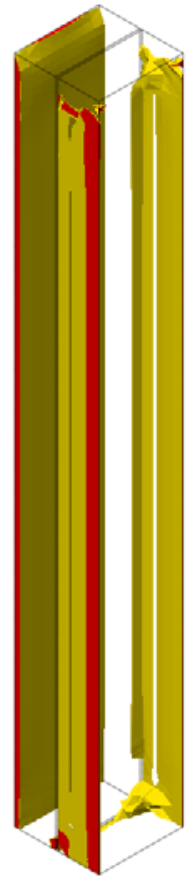

(b)

(c)

Figura 5.26 - (a) Panorama da tensão principal S1 no bloco de concreto; (b) Região do bloco onde a tensão S1 excedeu a tensão de tração no concreto; (c) Fissuração no concreto referente à força máxima no Modelo M3-E. 


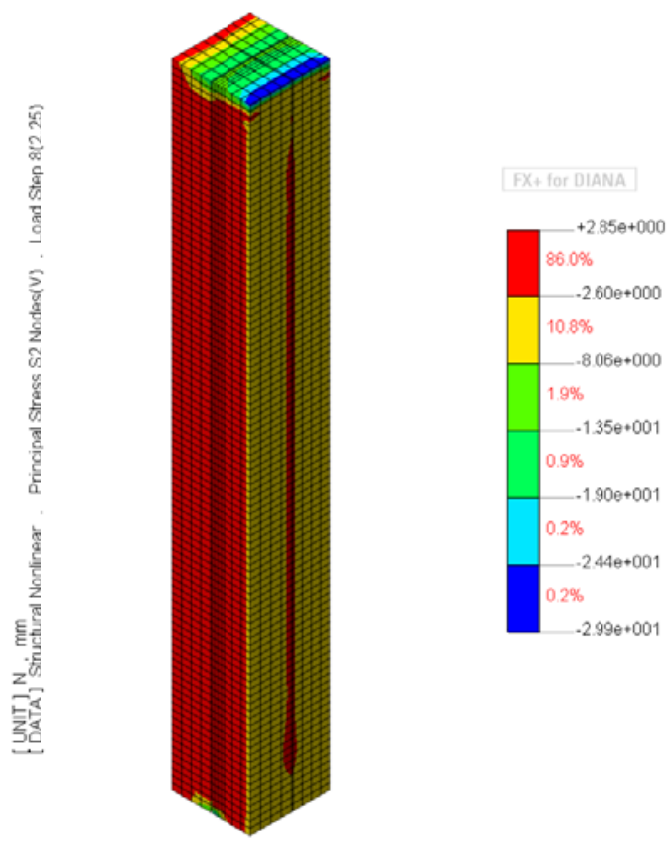

Figura 5.27 - (a) Panorama da tensão principal S2 no bloco de concreto no Modelo 3.

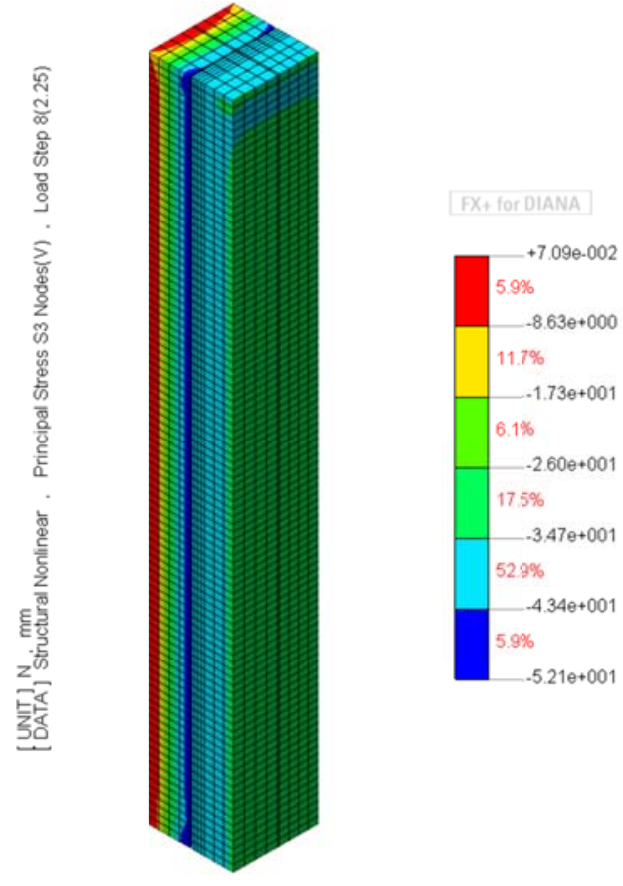

(a)

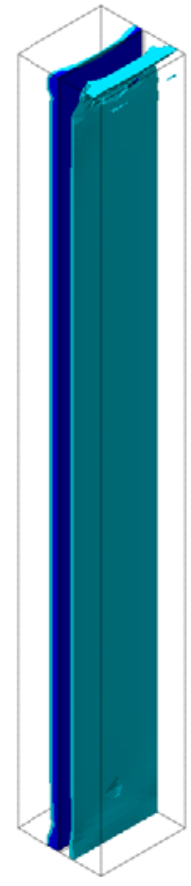

(b)

Figura 5.28 - (a) Panorama da tensão principal S3 no bloco de concreto; (b) Região do bloco onde a tensão S1 excedeu a tensão de compressão resistente do concreto no Modelo M3-E. 


\subsubsection{Análise Paramétrica}

Vários parâmetros que podem ser relevantes para a definição do comportamento estrutural dos pilares mistos não foram avaliados no programa experimental desenvolvido. Desta forma, foi desenvolvida uma análise paramétrica considerando as variáveis apresentadas na Tabela 5.7.

Tabela 5.7 - Variáveis avaliadas na análise paramétrica

\begin{tabular}{cc}
\hline Parâmetros avaliados & \\
\hline Dimensões da seção - bf x d (mm) & $125 \times 131,36$ \\
Espessura da chapa do perfil - $\mathrm{t}(\mathrm{mm})$ & 3,18 e 4,75 \\
Excentricidade no carregamento $-\mathrm{e}(\mathrm{mm})$ & $4.5,10,20$ \\
fck (MPa) & 30,50 e 80 \\
Tipo de Armadura & Convencional, Tela de aço soldada e fibras de aço \\
\hline
\end{tabular}

Ao todo foram avaliados 18 pilares mistos, cujas características são apresentadas na Tabela 5.8.

Tabela 5.8 - Características dos modelos numéricos da análise paramétrica

\begin{tabular}{cccccc}
\hline Modelo & Armadura & Concreto & $\left.\boldsymbol{f}_{\boldsymbol{c k}} \mathbf{( M P a}\right)$ & $\mathbf{t} \mathbf{( \mathbf { m m } )}$ & $\mathbf{e} \mathbf{( \mathbf { m m } )}$ \\
P1 & Convencional & Convencional & 50 & 3,18 & 4,5 \\
P2 & Convencional & Convencional & 30 & 3,18 & 4,5 \\
P3 & Convencional & Convencional & 80 & 3,18 & 4,5 \\
P4 & Convencional & Convencional & 50 & 3,18 & 10 \\
P5 & Convencional & Convencional & 50 & 3,18 & 20 \\
P6 & Convencional & Convencional & 50 & 4,75 & 4,5 \\
P7 & Tela de aço soldada & Convencional & 50 & 3,18 & 4,5 \\
P8 & Tela de aço soldada & Convencional & 30 & 3,18 & 4,5 \\
P9 & Tela de aço soldada & Convencional & 80 & 3,18 & 4,5 \\
P10 & Tela de aço soldada & Convencional & 50 & 3,18 & 10 \\
P11 & Tela de aço soldada & Convencional & 50 & 3,18 & 20 \\
P12 & Tela de aço soldada & Convencional & 50 & 4,75 & 4,5 \\
P13 & - & Adição de fibras & 50 & 3,18 & 4,5 \\
P14 & - & Adição de fibras & 30 & 3,18 & 4,5 \\
P15 & - & Adição de fibras & 80 & 3,18 & 4,5 \\
P16 & P17 & Adição de fibras & 50 & 3,18 & 10 \\
P18 & - & Adição de fibras & 50 & 3,18 & 20 \\
\hline & Adição de fibras & 50 & 4,75 & 4,5 \\
\hline
\end{tabular}


As características mecânicas do concreto, como módulo de elasticidade e energia de fraturamento, foram estimadas de acordo com as equações apresentadas no item 3.3.

\subsubsection{Influência da espessura da chapa do perfil metálico}

A Figura 5.29 apresenta as curvas força vs. encurtamento vertical para os pilares com diferentes espessuras da chapa que compõe o perfil metálico a fim de avaliar a influência desta variável para as configurações com armadura convencional, tela de aço soldada e concreto com adição de fibras de aço.

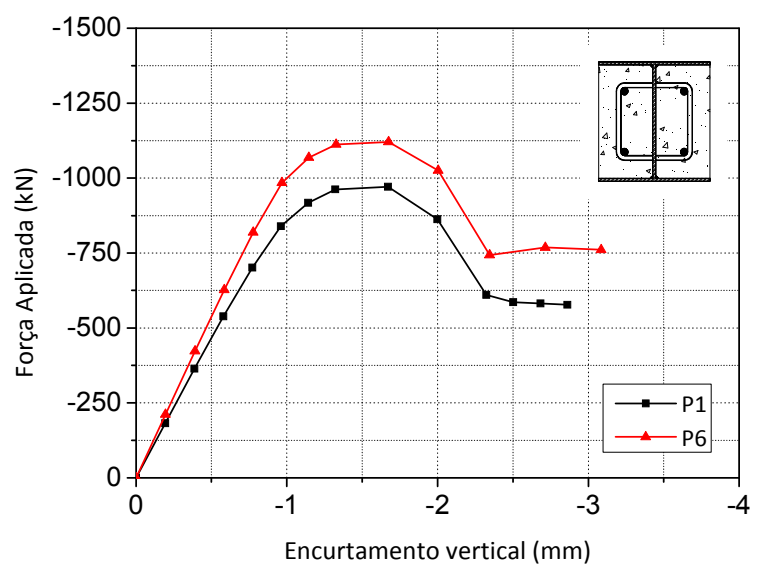

(a)

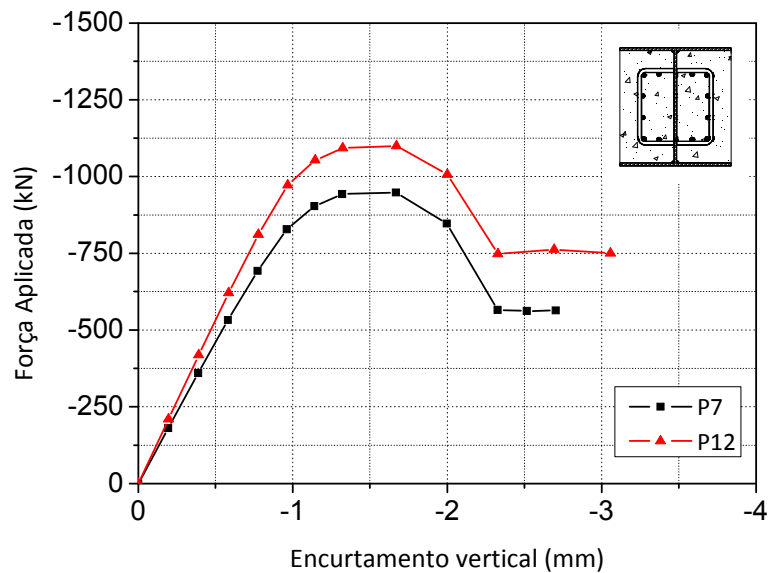

(b)

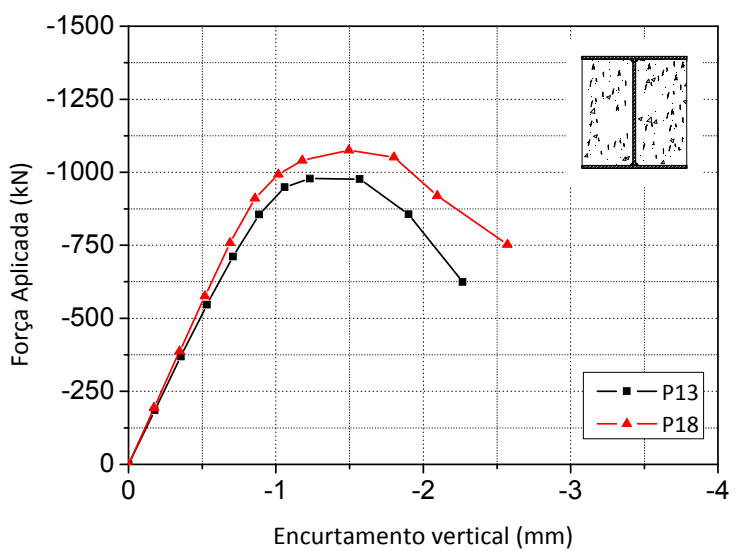

(c)

Figura 5.29 - Influência da espessura da chapa na curva força vs. deslocamento para palares com (a) armadura convencional; (b) tela de aço; (c) concreto com fibras

Verifica-se, como esperado, um aumento da capacidade resistente e da rigidez do pilar misto com o aumento da espessura da chapa do perfil; todavia nota-se que a ruptura ocorre para o mesmo valor de encurtamento vertical, indicando que a ruptura está relacionada com as 
características atribuídas ao concreto. Além disso, observa-se nos gráficos da Figura 5.29 que, após a ruptura, a capacidade resistente residual é maior para os pilares com chapas de maior espessura, indicando que o aço do perfil, por meio do escoamento da seção, é o principal responsável pela capacidade resistente residual.

Observa-se na Figura 5.29 - (c) que para os pilares com utilização de concreto com adição de fibras, o aço do perfil metálico tem maior influência no comportamento global do pilar, modificando de maneira sutil o ponto de ruptura.

\subsubsection{Influência da resistência à compressão do concreto}

A Figura 5.30 apresenta as curvas força vs. encurtamento vertical para os pilares mistos com concreto de revestimento de 30,50 e $80 \mathrm{MPa}$ nas três configurações estudadas (com armadura convencional, tela de aço soldada e concreto com adição de fibras de aço).

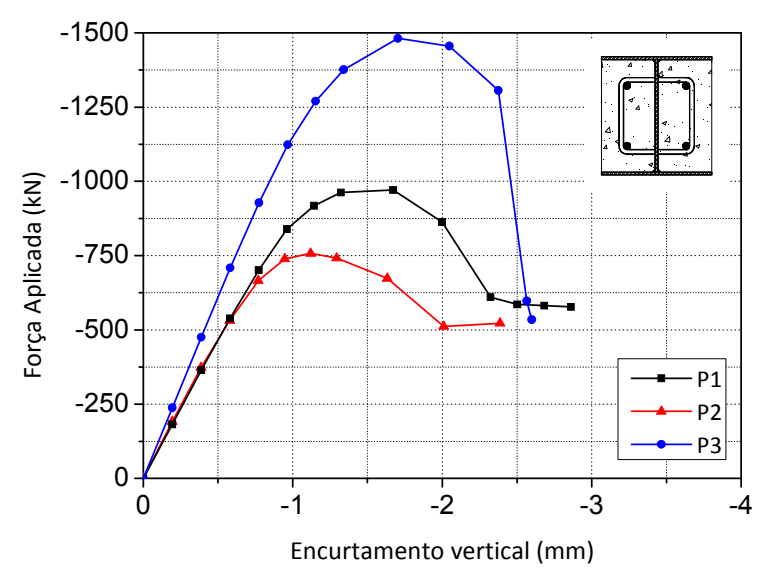

(a)

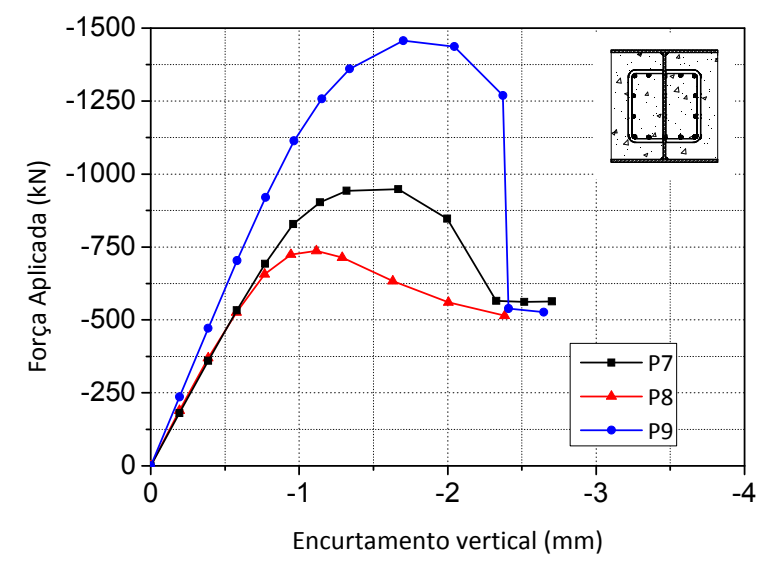

(b)

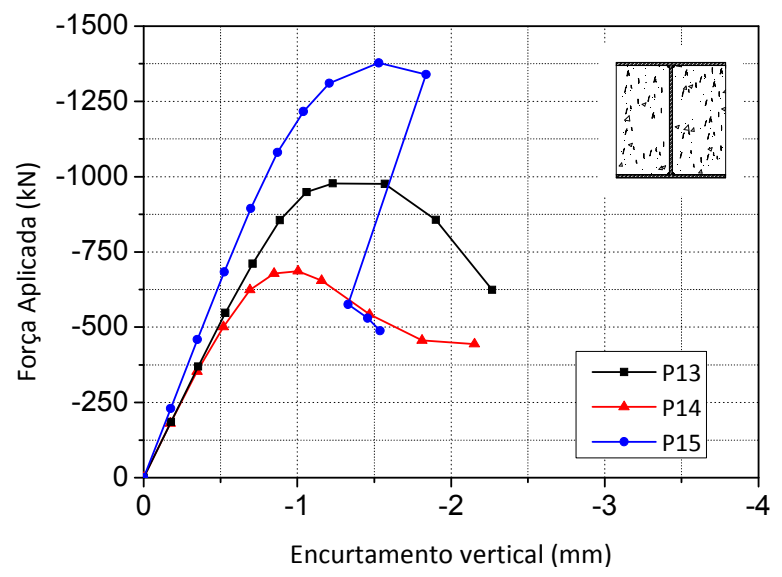

(c)

Figura 5.30 - Influência da espessura da chapa na curva força vs. deslocamento para palares com (a) armadura convencional; (b) tela de aço; (c) concreto com fibras 
Observa-se que os pilares mistos com concretos de 30 e $50 \mathrm{MPa}$ possuem rigidezes bastante próximas; já para concretos de $80 \mathrm{MPa}$ há um aumento de rigidez significativo e uma queda brusca da capacidade resistente após a força máxima. Este comportamento está intimamente relacionado às propriedades mecânicas atribuídas de acordo com os códigos normativos para concreto de $80 \mathrm{MPa}$, que penalizam a energia de fraturamento para concretos de maiores resistências.

O comportamento global expresso em termos da curva força aplicada vs. encurtamento vertical é bastante similar para os pilares com armadura convencional e com a tela de aço soldada; já os pilares com o concreto com adição de fibras de aço a ruptura ocorreu de modo brusco, com a fissuração concentrada na base do pilar.

\subsubsection{Influência de excentricidades na força aplicada}

A Figura 5.31 apresenta as curvas força vs. encurtamento vertical para os pilares mistos onde carregamento foi aplicado com excentricidades no valor de 4,5; 10 e $20 \mathrm{~mm}$ para as três configurações estudadas (com armadura convencional, tela de aço soldada e concreto com adição de fibras de aço). 


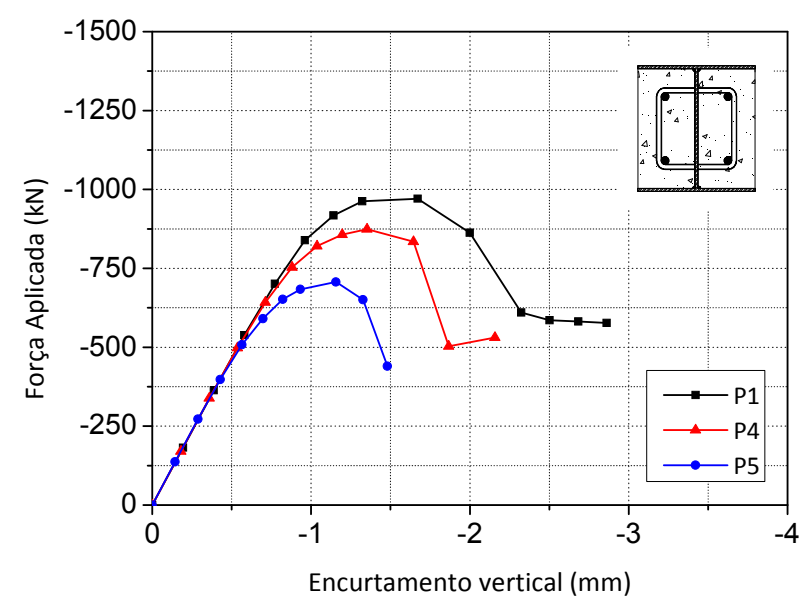

(a)

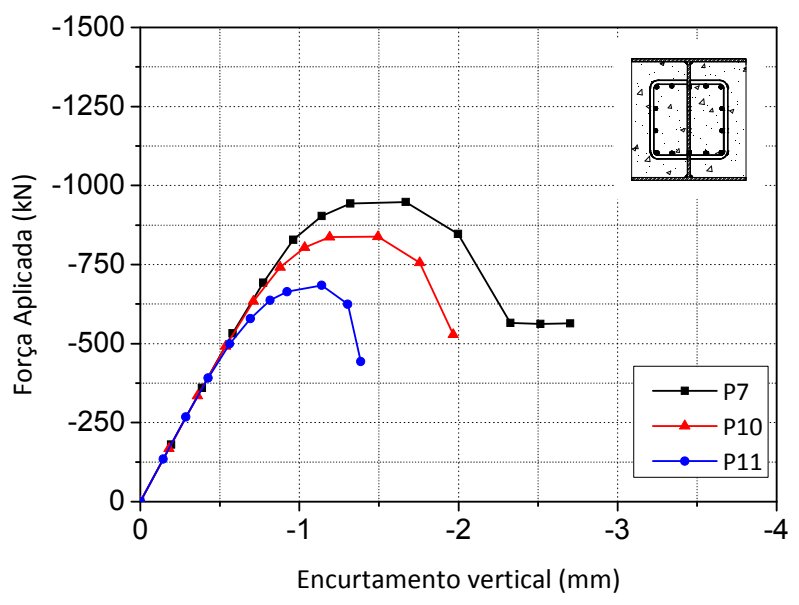

(b)

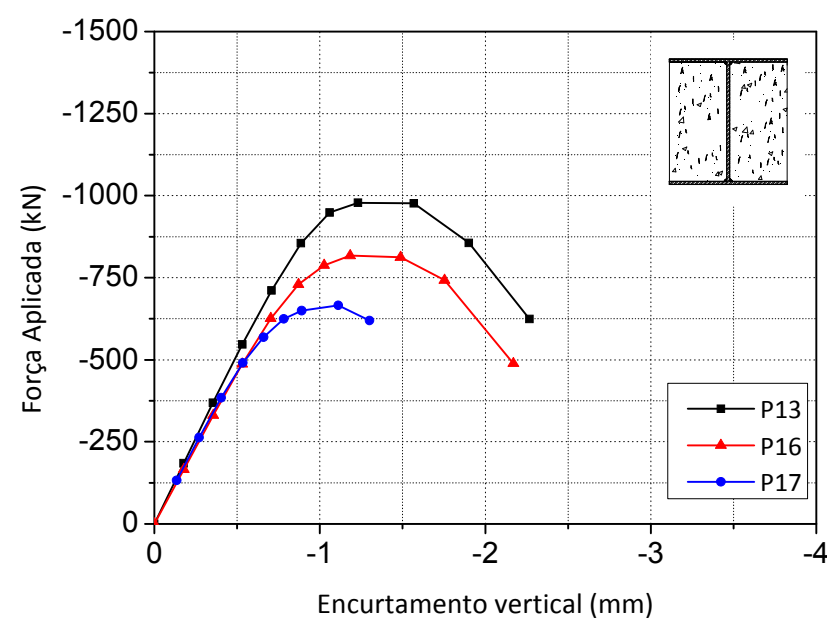

(c)

Figura 5.31 - Influência da espessura da chapa na curva força vs. deslocamento para palares com (a) armadura convencional; (b) tela de aço; (c) concreto com fibras

Nos gráficos da Figura 5.31 fica claro que o aumento da excentricidade no carregamento diminui a capacidade resistente, mas não altera a rigidez do elemento. Também há uma diminuição da ductilidade com o aumento da excentricidade, acarretando maior concentração de fissuras na face mais solicitada do pilar.

\subsubsection{Avaliação qualitativa da influência da consideração da interface aço-concreto}

Foi realizada uma análise qualitativa das alterações no comportamento global que a consideração de uma interface entre os componentes dos pilares mistos parcialmente revestidos com concreto reforçado com fibras de aço submetidos à flexo-compressão.

Para isto foi gerado um novo modelo numérico cujos componentes são apresentados na Figura 5.32.Para representar os componentes chapa de topo, perfil metálico e concreto 
foram utilizados os elementos sólidos $\mathrm{HX} 24 \mathrm{~L}$, já utilizados nas demais análises realizadas neste trabalho.

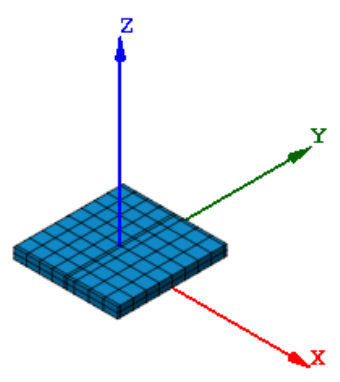

(a)

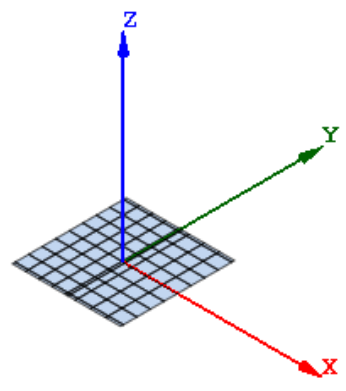

(b)

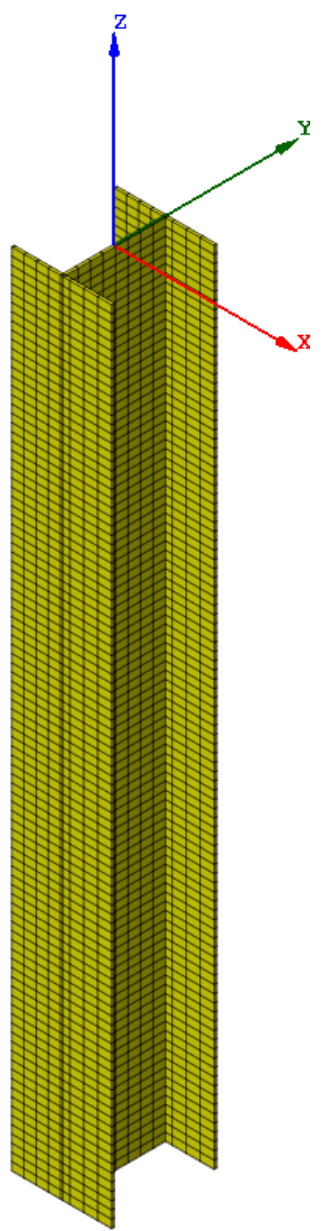

(c)

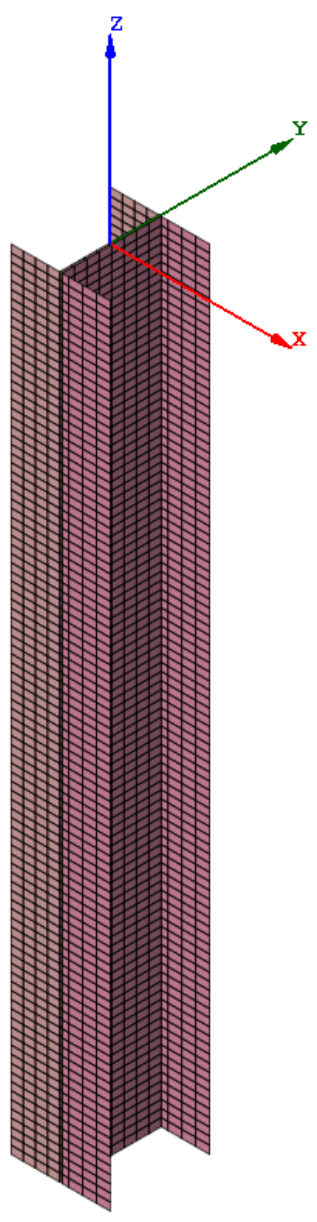

(d)

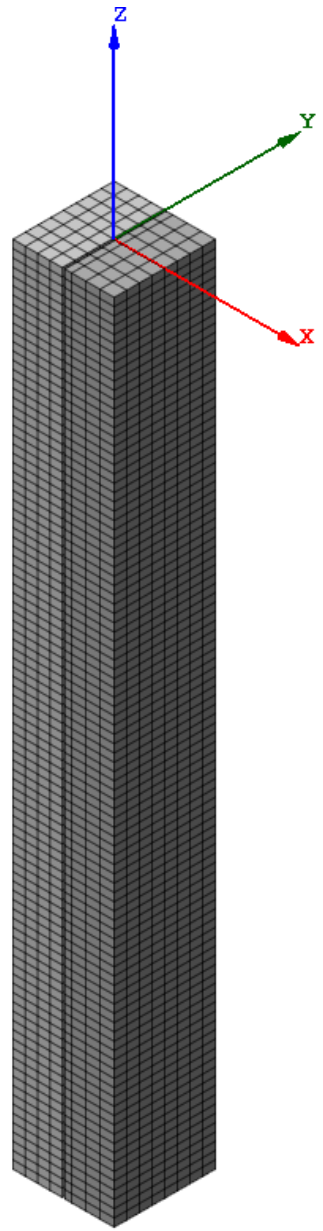

(e)

Figura 5.32 - Componentes do modelo numérico: (a) Chapa de topo; (b) Interface chapa-pilar; (c) Perfil metálico; (d) Interface perfil-Concreto; (e) Blocos de concreto.

No que diz respeito à modelagem das interfaces (Figura 5.32 - (b); (d)) foi utilizado o elemento finito de interface Q24IF (Figura 5.23). Trata-se de um elemento de interface entre dois planos numa configuração tridimensional com interpolação linear.

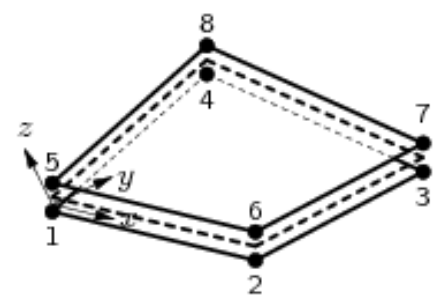

(a)

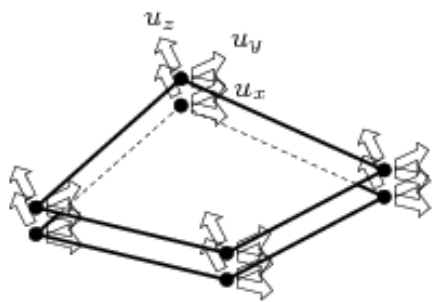

(b)

Figura 5.33 - Elemento finito de interface Q24IF: (a) Tipologia; (b) Deslocamentos (DIANA, 2012). 
O software DIANA ${ }^{\circledR}$ possui vários modelos para descrição das interfaces. Como não foram realizados ensaios específicos para caracterização da interface foi adotado o modelo mais simples de interface linear. Para simulação numérica da interface linear é necessário informar parâmetros de rigidez tangencial $\left(K_{t}\right)$ e normal $\left(K_{n}\right)$ iniciais. O parâmetro de rigidez tangencial é a relação entre a tração devido ao cisalhamento e o deslocamento correspondente, e o parâmetro de rigidez normal é a relação entre a tração devido ao esforço normal e o deslocamento correspondente.

Para avaliar a sensibilidade do modelo à variação destes parâmetros, foram testadas três combinações de valores para a interface perfil-concreto indicadas na Tabela 5.9. Com estas combinações busca-se verificar qual parâmetro tem maior influência no comportamento do pilar misto.

Tabela 5.9 - Interfaces avaliadas

\begin{tabular}{cc}
\hline Modelo & Tipo de Interface \\
Interface 1 & Aderência perfeita \\
Interface 2 & Rigidez normal $=10^{10} \mathrm{~N} / \mathrm{mm}^{3}$ e Rigidez transversal $=0,01 \mathrm{~N} / \mathrm{mm}^{3}$ \\
Interface 3 & Rigidez normal $=0,01 \mathrm{~N} / \mathrm{mm}^{3}$ e Rigidez transversal $=10^{10} \mathrm{~N} / \mathrm{mm}^{3}$ \\
\hline
\end{tabular}

Para a interface entre a chapa de topo e o pilar foi adotado em todas as análises um valor mínimo para a rigidez tangencial e um valor muito alto para a rigidez normal. Deste modo, é possível que a chapa deslize sobre o pilar sem penetrar a seção.

A Figura 5.34 apresenta os resultados experimentais obtidos para o modelo M3-E comparado com os resultados numéricos obtidos para as diferentes interfaces. Observa-se que a melhor correlação entre as curvas experimental e numérica ocorre para uma rigidez tangencial muito elevada, o que sugere o comportamento de aderência perfeita, justificando os bons resultados obtidos com a Interface 1 . 


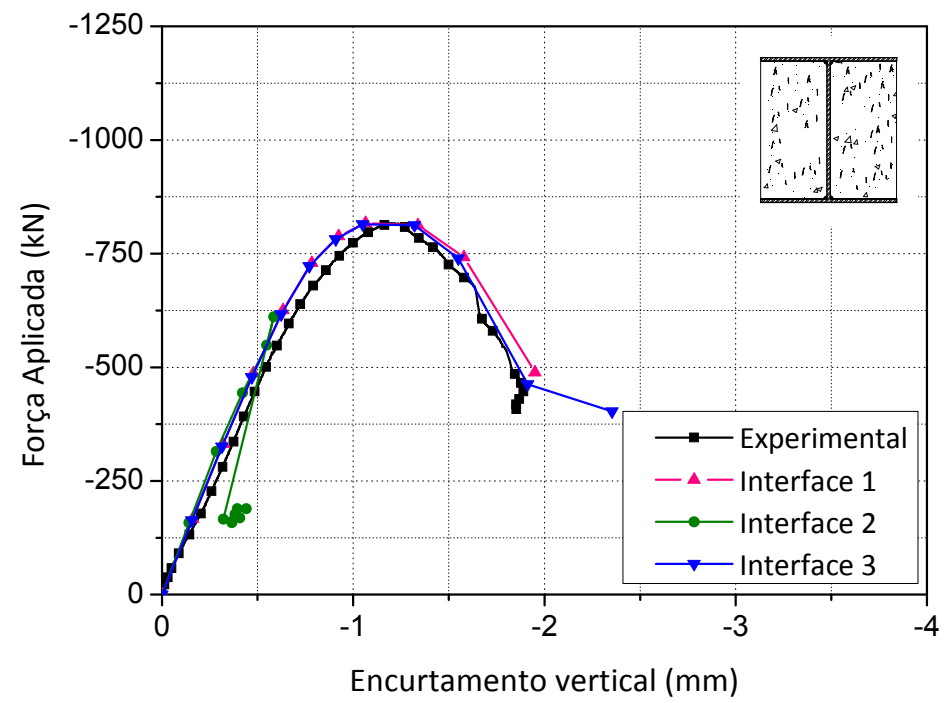

Figura 5.34 - Curva força aplicada vs. encurtamento vertical para modelos com interface

Observou-se que para a Interface 2 a fissuração ocorria de modo concentrado nas extremidades do pilar, já para a Interface 3 a fissuração ocorreu de modo distribuído, mais compatível com o comportamento experimental.

\subsection{Considerações finais}

Por meio das simulações numéricas preliminares percebeu-se que os valores de energia de fratura tem papel determinante nos resultados numéricos. Constatou-se que a energia de fratura à compressão define o ponto onde ocorre o inicio da queda da capacidade resistente do elemento. Já a energia de fratura à tração modifica o início e padrão da fissuração. Além disso, verificou-se que para um dado valor de resistência à compressão do concreto há uma faixa de valores de energia de fraturamento que podem modificar os resultados.

O modelo numérico final desenvolvido para pilares mistos é capaz de reproduzir a capacidade resistente do modelo físico desde que seja considerada uma excentricidade acidental. O pós-pico pode ser bem representado para os modelos M1 e M3-E. Ademais, o padrão de fissuração observado experimentalmente foi satisfatoriamente reproduzido pela simulação, isto é, fissuras concentradas na face mais comprimida ao longo da interface entre as mesas e o concreto.

Da análise paramétrica verificou-se que o aumento da espessura do perfil metálico aumenta a capacidade resistente do pilar sem modificar o comportamento estrutural em 
termos de curva força aplicada vs. encurtamento do pilar. Já o aumento da resistência do concreto modifica também o comportamento estrutural, tornando o mais frágil.

A consideração de excentricidades ao carregamento, ou seja, passando a considerar o pilar solicitado a flexo-compressão, há uma redução significativa da capacidade resistente e para grandes valores de excentricidade há uma ruptura abrupta não sendo possível, numericamente, reproduzir o trecho pós-pico.

Finalmente, avaliou-se, qualitativamente, a possibilidade de considerar um deslizamento relativo entre o aço e concreto por meio de uma interface no modelo numérico. Nesta análise notou-se que o comportamento mais próximo ainda é o considerando a aderência perfeita. Entretanto, ensaios experimentais são necessários para melhor caracterização desta interface. 


\section{Conclusões e sugestões para novas pesquisas}

Este trabalho tinha como objetivo principal avaliar o comportamento estrutural de pilares mistos parcialmente revestidos, em particular a capacidade resistente e integridade do concreto. Para isto foram realizadas as etapas: Revisão bibliográfica, Investigação experimental e simulações numéricas. A seguir são sintetizadas as principais conclusões obtidas de cada etapa.

\section{Revisão bibliográfica}

Inicialmente desenvolveu-se uma revisão bibliográfica buscando entender os mecanismos resistentes da seção mista. Neste sentido, pode-se perceber que um aspecto relevante no comportamento da seção mista são os fenômenos de instabilidades locais do perfil de aço, sendo especialmente significativos para chapas finas que podem compor os perfis de aço.

Estudos demonstraram ainda que a utilização de barras transversais soldadas entre as mesas do perfil de aço conferem maior rigidez às mesas do perfil, que passam a ter maior resistência frente à expansão lateral do concreto. Além disso, contribuem para o confinamento do concreto, resultando em maior capacidade residual no trecho pós-pico e, consequentemente, pilares com maior capacidade de deformação e ductilidade.

Em outras pesquisas, observou-se que a adição de fibras de aço ao concreto traz benefícios para a resposta estrutural e para a ductilidade do pilar misto parcialmente revestido.

Outra característica relevante para o comportamento conjunto ao longo do pilar são os mecanismos de aderência aço-concreto. Estudos analisaram esse aspecto e contatou-se comportamento conjunto até mesmo quando o pilar misto parcialmente revestido é solicitado por carregamentos excêntricos. Além disso, notou-se que a rugosidade da superfície tem papel determinante nas forças de aderência desenvolvidas na interface.

Observou-se ainda que a maioria dos estudos recentes sobre pilares mistos parcialmente revestidos foca na utilização dos elementos mistos em situação de sismo ou submetidos a altas temperaturas (incêndio), aspectos determinantes para a maior aceitação desses pilares. Estes estudos demostraram que os pilares mistos parcialmente revestidos podem ser adequados para áreas de sismos devido à ductilidade e à capacidade de dissipação 
de energia observada nos ensaios com carregamentos cíclicos. E para as situações de incêndio os pilares mistos revelaram melhor comportamento que os pilares de aço.

Outra linha de pesquisa bastante empregada foca no desenvolvimento de modelos numéricos simplificados que representem o comportamento dos pilares mistos parcialmente revestidos, cuja principal dificuldade encontra-se na caracterização da interface aço-concreto. Há autores que utilizam elementos de interface, enquanto outros buscam alternativas para evitar a discretização da interface, como por exemplo, a representação do concreto por meio de molas ou com uma seção de aço equivalente.

De um modo geral, observou-se que estudos envolvendo pilares mistos parcialmente revestidos são recentes e necessitam ser ampliados.

\section{Investigação experimental}

$\mathrm{Na}$ sequência, realizou-se um programa experimental, onde foram avaliados seis pilares mistos parcialmente revestidos com três configurações de armadura, modelo 1 armadura convencional; modelo 2 - armadura com telas de aço soldado e modelo 3 substituição da armadura por fibras de aço no concreto.

Pelo registro de deformações notou-se que a alma do perfil metálico apresenta grandes valores de deformação no trecho pós-pico da curva força vs. deslocamento, o que sugere que a alma contribui para a capacidade resistente residual do elemento em estudo. Já a mesa do perfil metálico exibe instabilidades locais para a força máxima as quais se intensificam no trecho pós-pico e assim diminuem sua contribuição para a capacidade resistente do conjunto. O modo de falha constatado foi o esgotamento da seção mista por esmagamento do concreto seguido de instabilidades locais da mesa.

Cabe destacar que em todos os ensaios experimentais ocorreram deslizamentos da extremidade superior do pilar e excentricidades acidentais na aplicação do carregamento, assinalando a dificuldade da aplicação de um carregamento centrado, seja em laboratório ou em obras reais.

O modelo 1 apresentou comportamento bastante dúctil. A capacidade resistente foi de $943 \mathrm{kN}$ e $974 \mathrm{kN}$, para o exemplar e réplica, respectivamente. O comportamento estrutural global do modelo 2 foi similar ao modelo $1 \mathrm{em}$ termos de rigidez, capacidade de deformação e capacidade resistente, resistindo a $954 \mathrm{kN}$ e $950 \mathrm{kN}$, o exemplar e a réplica, respectivamente. $\mathrm{O}$ modelo $\mathrm{M} 3$ teve uma capacidade resistente também bastante próxima $(958 \mathrm{kN})$, porém apresenta menor rigidez e capacidade de deformação. Não se pode afirmar 
com clareza o que levou à diminuição destes parâmetros, acredita-se que esteja associada ao mau posicionamento deste na máquina de ensaios e excentricidades acidentais.

Finalmente no modelo M3-E que foi submetido à flexo-compressão com excentricidade de $10 \mathrm{~mm}$ houve uma redução de $15 \%$ na capacidade resistente em comparação com o modelo de referência (modelo 1). Os resultados experimentais comprovaram a existência do comportamento conjunto na ausência de armaduras mesmo quando o pilar é solicitado a carregamentos excêntricos.

Ao se comparar os resultados experimentais com os resultados obtidos pelos procedimentos da norma ABNT - NBR 8800:2008 verificou-se que os resultados analíticos superestimam a capacidade resistente dos pilares mistos. Já para o modelo físico que foi submetido à flexo-compressão os resultados da norma ficam a favor da segurança, com valores abaixo dos obtidos experimentalmente.

\section{Simulações numéricas}

Finalmente foram realizadas simulações numéricas no pacote computacional Fx + DIANA $^{\circledR}$ para representar o comportamento dos pilares mistos e extrapolar os resultados experimentais. Para isto foram realizadas simulações numéricas preliminares que permitiram avaliar como os parâmetros numéricos poderiam influenciar na resposta estrutural, além de ajudar na previsão da capacidade resistente do elemento.

Notou-se, nas análises preliminares, que o valor da energia de fratura à compressão define o ponto onde ocorre o início da queda da capacidade resistente do elemento e a energia de fratura à tração modifica o início e padrão da fissuração. Verificou-se que para um dado valor de resistência à compressão do concreto há uma faixa de valores de energia de fraturamento que podem modificar os resultados.

O modelo numérico final desenvolvido para pilares mistos foi capaz de reproduzir a capacidade resistente do modelo físico quando considerada uma excentricidade acidental. $\mathrm{O}$ pós-pico pode ser bem representado para os modelos M1 e M3-E. Ademais, o padrão de fissuração observado experimentalmente foi satisfatoriamente reproduzido pela simulação, isto é, fissuras concentradas na face mais comprimida ao longo da interface entre as mesas e o concreto.

Da análise paramétrica verificou-se que o aumento da espessura do perfil metálico aumenta a capacidade resistente do pilar sem modificar o comportamento estrutural em termos de curva força aplicada vs. encurtamento do pilar. Já o aumento da resistência do concreto modifica também o comportamento estrutural, tornando-o mais frágil. A 
consideração de excentricidades no carregamento produz uma redução significativa da capacidade resistente. Para grandes valores de excentricidade há uma ruptura abrupta não sendo possível, numericamente, reproduzir o trecho pós-pico.

Finalmente, a possibilidade de considerar um deslizamento relativo entre o aço e concreto por meio de uma interface no modelo numérico foi avaliada. Nesta análise notou-se que o comportamento mais próximo ainda é o considerando a aderência perfeita. Entretanto ensaios experimentais são necessários para melhor caracterização desta interface.

Por meio dos estudos realizados a substituição da armadura por alternativas como a tela de aço soldada ou o uso de concreto com adição de fibras de aço, se mostraram promissoras, sendo necessários, no entanto, estudos mais abrangentes para permitir a sua utilização corrente.

\subsection{Sugestão para pesquisas futuras}

Visando dar continuidade à pesquisa do comportamento estrutural do pilar misto parcialmente revestido, são sugeridos os estudos a seguir:

- Avaliação da interface aço-concreto por meio de ensaios de arrancamento (push-out);

- Consideração da utilização de conectores de cisalhamento fora da zona de introdução de carga para configurações de pilares sem armadura;

- Análise de outras taxas e tamanhos de fibras de aço para o concreto com fibras;

- Realização de ensaios de pilares mistos sem armadura convencional em situação de incêndio ou cargas cíclicas e;

- Realização de um programa experimental mais completo, onde possam ser avaliados pilares de outras dimensões e resistência à compressão do concreto.

Acredita-se que a continuidade das pesquisas relativas aos pilares mistos parcialmente revestidos contribuirá para a disseminação das estruturas mistas em geral, de modo a proporcionar o desenvolvimento tecnológico do setor da construção civil como um todo em nosso país. 


\section{Referências bibliográficas}

AMERICAN SOCIETY FOR TESTING AND MATERIALS. ASTM A 370-97a: Standard Test Methods and Definitions for Mechanical Testing of Steel Products. West Conshohocken: American Society for Testing and Materials, 1997.

ARQUITETURA \& AÇO (2013). Rio de Janeiro: CBCA - Centro Brasileiro de Construção em aço, Março, 2013. Trimestral.

ARAÚJO, D. L.; CARMO, L. C.; PRADO, A. A. (2007). Determinação da curva tensãodeformação à tração de concretos reforçados com fibras de aço via modelagem computacional. In: CMNE/CILAMCE, 2007, Porto, Portugal. Anais. Porto, Portugal: 2007. p. 17.

ASSOCIAÇÃO BRASILEIRA DE NORMAS TÉCNICAS. NBR 15530: Fibras de aço para concreto - Especificações. Rio de Janeiro, 2007.

$174 \mathrm{p}$.

NBR 6118: Projeto de estruturas de concreto - Procedimento. Rio de Janeiro, 2007.

NBR 6892-1: Materiais metálicos — Ensaio de Tração Parte 1: Método de ensaio à temperatura ambiente. Rio de Janeiro, 2013. 70p.

NBR 8800: Projeto de estruturas de aço e de estruturas mistas de aço e concreto de edifícios. Rio de Janeiro, 2008. 237p.

BASTOS, P. S. S. (1999). Análise Experimental de dormentes de concreto protendido reforçados com fibras de aço. 1999. 256p. Tese (Doutorado em Estruturas). Escola de Engenharia de São Carlos, da Universidade de São Paulo. São Carlos, São Paulo. 1999.

BARROS, J. A. O.; FIGUEIRAS, J. A. (1999). Flexural behavior of sfrc: testing and modeling. Journal of Materials in Civil Engineering, v. 11, n. 4, p. 331-339, Nov. 1999.

BENTUR, A.; MINDESS, S. (1990). Fibre reinforced cementitious composites. London: Elsevier Applied Science. 1990.

BEGUM, M.; GHOSH, D.; Finite Element Analysis of Partially Encased Composite Columns with Equivalent Steel Section. Journal of Structural Engineering, v. 133, n. 3, p. 326-334, Mar. 2002

CEB - Comité Euro-International Du Béton. CEB MODEL CODE 1990, 1990.

CHEN, Y.; WANG, T.; YANG, J.; ZHAO, X. (2010). Test and Numerical Simulation of Partially Encased Composite Columns Subject to Axial and Cyclic Horizontal Loads. International Journal of Steel Structures, v. 10, n. 4, p. 385-393, Dec. 2010.

CHICOINE, T.; TREMBLAY, R.; MASSICOTTE, B.; RICLES, J. M.; LU, L. (2002). Behavior and Strength of partially encased composite columns with built-up shapes. Journal of Structural Engineering, Canada, v.128, n. 3, p. 279-288, Mar. 2002. 
CHICOINE, T.; TREMBLAY, R.; MASSICOTTE, B. (2003); Long-term Behavior and Strength of partially encased composite columns made with built-up steel shapes. Journal of Structural Engineering, Canada, v.129, n. 2, p. 141-150, Feb. 2003.

DE NARDIN, S. (1999). Estudo teórico-experimental de pilares mistos compostos por tubos de aço preenchidos com concreto de alta resistência. 1999. 148p. Dissertação (Mestrado em Estruturas) - Escola de Engenharia de São Carlos, Universidade de São Paulo, São Carlos, 1999.

(2003). Pilares mistos preenchidos: estudo da flexo-compressão e de ligações viga-pilar. 2003. 341p. Tese (Doutorado em Estruturas) - Escola de Engenharia de São Carlos, Universidade de São Paulo, São Carlos, 2003.

DIANA, T. DIANA Finite Element Analysis. User's Manual release 9.4.4. Delft, Netherland, 2012.

EUROPEAN COMMITTEE FOR STANDARDIZATION. Eurocode 2: Design of concrete structures - Part 1: General rules and rules for buildings. Brussels, 2004

EUROPEAN COMMITTEE FOR STANDARDIZATION. Eurocode 4: Design of composite steel and concrete structures - Part 1-1: General rules and rules for buildings. Brussels, 2004

ELNASHAI, A.S.; BRODERICK, B.M. (1994a). Seismic resistance of composite beamcolumns in multi-storey structures. Part 1: Experimental studies. Journal of Constructional Steel Research, v.30, n. 03, p. 201-229, Oxford, 1994.

(1994b). Seismic resistance of composite beam-columns in multi-storey structures. Part 2: Analytical model and discussion of results. Journal of Constructional Steel Research, Oxford, v.30, n. 03, p. 231-258, 1994.

ELLOBODY, E; YOUNG, B. (2011). Numerical simulation of concrete encased steel composite columns. Journal of Constructional Steel Research, v. 67, p. 211-222, 2011.

FEENSTRA, P. H. (1993). Computational Aspects of Biaxial Stress in Plain and Reinforced Concrete. PhD thesis, Delft University of Technology, 1993.

FIGUEIREDO, A. D. (1997). Parâmetros de controle e dosagem do concreto projetado com fibras de aço. 1997. Tese (Doutorado). Escola Politécnica, Universidade de São Paulo. São Paulo, 1997.

FIGUEIREDO, A. D. (2000). Concreto com fibras de aço. 2000. Boletim técnico. Escola Politécnica, Universidade de São Paulo. São Paulo, 2000.

FIGUEIREDO, L. M. B. (1998). Projeto e construção de pilares mistos aço-concreto. São Carlos. 1998. 142p. Dissertação (Mestrado em Estruturas) - Escola de Engenharia de São Carlos, Universidade Federal de São Paulo, 1998.

FIGUEIREDO, L. M. B.; NETO, P. J. C.; FARIA, H. M. (2008). A nova normalização brasileira sobre fibras de aço. Revista Concreto \& Construções, São Paulo, a. XXXVI, n.50, p.67-75, abr. mai. jun. 2008. Disponível em: $<$ http://www.ibracon.org.br $>$. Acesso em: 8 out. 2012. 
GAIGA, F. (2008). Análise da distribuição das tensões de cisalhamento na interface açoconcreto de pilares mistos parcialmente revestidos. 2008. 180p. Dissertação (Mestre em Engenharia Civil) - Faculdade de Engenharia Civil, Arquitetura e Urbanismo, Universidade Estadual de Campinas, Campinas, 2008.

HUNAITI, Y.M.; FATTAH, B. A.(1994). Design Considerations of Partially Composite Columns. Proc. Inst. Civ. Eng., Struct. Build., v.106, n.2, p.75-82, Feb. 1994.

JAPAN SOCIETY OF CIVIL ENGINEERS. JSCE-SF4. Method of tests for flexural strength and flexural toughness of steel fiber reinforced concrete. Concrete Library of JSCE. Part III-2 Method of tests for steel fiber reinforced concrete. $\mathrm{N}^{\mathrm{o}} 3$ June 1984. p.58-61.

KORZEN, M.; RODRIGUES, J. P. C; CORREIA, A. J. P. M. (2010). Composite Columns Made of Partially Encased Steel Sections Subjected to Fire, In: Proceedings of the International Conference SIF10 - Structures in Fire, Michigan, 2010. p. 341-348

LIMA JÚNIOR, H. C. (2003). Avaliação da ductilidade de pilares de concreto armado, submetidos à flexo-compressão reta com e sem adição de fibras metálicas. 2003. 324p. Tese (Doutorado em Estruturas) - Escola de Engenharia de São Carlos, Universidade de São Paulo, São Carlos, 2003.

MANTOVANI, E. C. (2006). Comportamento de pilares mistos, com ênfase na zona de introdução de cargas. 2006. 225p. Dissertação (Mestre em Estruturas) - Escola de Engenharia da Universidade Federal de Minas Gerais, Belo Horizonte, 2006.

MEHTA, P. K.; MONTEIRO, P. J. M. (2008). Concreto: Microestrutura, Propriedades e Materiais. Ed. 8. São Paulo: IBRACON, 2008.

MUISE, J. (2000). Behaviour of Simple Framing Connections to Partially Concrete Encased H Section Columns. 2010. 114p. Thesis (Master) - Dept. of Civil Engineering, University of Toronto, Toronto, Canada, 2010.

NUNES, N. L. (1998). Estudo da Influência da geometria da fibra de aço na tenacidade à flexão dos compósitos de matriz de concreto. 1998. 193p. Dissertação (Mestrado). Escola Politécnica, Universidade de São Paulo. São Paulo, 1998.

NUNES, N. L. (2006). Contribuição para a aplicação do concreto reforçado com fibras de aço em elementos de superfície restringidos. 2006. 253p. Tese (Doutorado). Escola Politécnica, Universidade de São Paulo. São Paulo, 2006.

NUNES, N. L.; AGOOYAN, V. (1998). A influência do fator de forma da fibra na tenacidade à flexão do concreto reforçado com fibras de aço. Boletim Técnico, São Paulo: EPUSP, 1998. $18 \mathrm{p}$.

OH, M. et. al. (2006). Structural Performance of Steel-Concrete Composite Column Subjected to Axial and Flexural Loading. Journal of Asian Architecture and Building Engineering. South Korea, v.5, n.1, p.153-160, May, 2006.

OLIVEIRA, W. L. A. (2008). Análise teórico-experimental de pilares mistos Preenchidos de seção circular. 2008. 251p. Tese (Doutorado em Estruturas) - Escola de Engenharia de São Carlos, Universidade de São Paulo, São Carlos, 2008. 
PECCE, M.; CERONI, F. (2010). Bond tests of partially encased composite columns. Advanced Steel Construction, Hong Kong, v. 6, n. 4, p. 1001-1018, 2010.

PRICKETT, B.S.; DRIVER, R.G. (2006). Behavior of Partially Encased Columns Made with High Performance Concrete. 2006. 221f. Structural Engineering Report no 262, Dept. of Civil and Enviroment Engineering, University of Alberta, AB, Canada, 2006.

RILEM Draft Recommendation. 50-FMC Committee Fracture Mechanics of Concrete. Determination of fracture energy of mortar and concrete by means of three-point bend tests on notched beams. Matériaux et Constructions, v. 33, pp. 347-351. (1985)

ROCHA, P. A. S. (2011). Resistência da ligação aço-concreto em pilares mistos parcialmente revestidos sob altas temperaturas. 2011. 89p. Tese (Doutorado em Engenharia Civil) - COPPE, Universidade Federal do Rio de Janeiro, Rio de Janeiro, 2011.

TREMBLAY, R.; MASSICOTTE, B.; FILION, I.; MARANDA, R. (1998). Experimental study on the behavior of partially encased composite columns made with light welded $H$ steel shapes under compressive axial loads. Proceedings - Annual Technical Session, Structural Stability Research Council. Atlanta: 1998. p. 195-204.

TREMBLAY, R. CHICOINE, T.; MASSICOTTE, B. (2002). Design equation for the capacity of partially encased non-columns. Proceedings, Composite Construction in steel and concrete IV, ASCE, Reston, VA, p.506-517, 2002.

VINCENT, R.; TREMBLAY, R. (2001). An Innovative Partially Composite Column System for High-Rise Buildings. Proceedings, North American Steel Construction Conf., Fort Lauderlade, FL., p. 30-3 a 30-17, 2001.

VECCHIO, J. F.; COLLINS, M. P. (1993) Compression Response of Cracked Reinforced Concrete. Journal of Structural Engineering, v. 119, n. 12. P. 3590-3610, 1993. 
Apêndice A 


\section{Planilha de Dimensionamento de Pilares Mistos NBR-8800:2008 MODELO 1}

\section{Dados de entrada}

Perfil Metálico:

Altura total

Largura da mesa

Espessura da mesa

Espessura da alma

Armadura

Número de barras

Diametro da barra

$\begin{array}{ll}\mathrm{d}:=131.36 & \mathrm{~mm} \\ \mathrm{bf}:=125 & \mathrm{~mm} \\ \mathrm{t}_{\mathrm{f}}:=3.18 & \mathrm{~mm} \\ \mathrm{t}_{\mathrm{w}}:=3.18 & \mathrm{~mm}\end{array}$

$\mathrm{n}:=4$

Barras

dia $:=8$

$\mathrm{mm}$

1.2 - Propriedades mecânicas dos Materiais $\left(\mathrm{kN} / \mathrm{cm}^{2}\right)$

Resistência Característica do Aço

Resistência Característica do Concreto

Resistência Característica do Armadura

Módulo Elasticidade do Aço do Perfil

Módulo de Elasticidade do Aço da Armadura

$$
\begin{array}{ll}
\mathrm{f}_{\mathrm{yk}}:=32.29 & \frac{\mathrm{kN}}{\mathrm{cm}^{2}} \\
\mathrm{f}_{\mathrm{ck}}:=5.46 & \frac{\mathrm{kN}}{\mathrm{cm}^{2}}
\end{array}
$$

$$
\mathrm{f}_{\mathrm{sk}}:=61 \quad \frac{\mathrm{kN}}{\mathrm{cm}^{2}}
$$

$$
\text { Es }:=22636 \quad \frac{\mathrm{kN}}{\mathrm{cm}^{2}}
$$

$\mathrm{Ea}:=20012.5 \quad \frac{\mathrm{kN}}{\mathrm{cm}^{2}}$

\section{3 - Comprimentos e coeficientes de flambagem}

Coeficiente de Flambagem em $\mathrm{x}$

Coeficiente de Flambagem em y

Comprimento de Flambagem em $\mathrm{x}$

Comprimento de Flambagem em y
$\mathrm{Kx}:=1$

$\mathrm{Ky}:=1$

$L x:=100$

$\mathrm{cm}$

Ly $:=100 \quad$ cm 


\section{4 - Solicitações de cálculo}

Momento Solicitante de Cálculo em x

Momento Solicitante de Cálculo em y

Normal Solicitante de Cálculo

Parcela da Normal devido a ação permanente e quase permanente

$$
\mathrm{M}_{\mathrm{X} . \mathrm{Sd}}:=0 \quad \mathrm{kNcm}
$$

$$
\mathrm{M}_{\mathrm{y} . \mathrm{Sd}}:=0 \quad \mathrm{kNcm}
$$

$$
\mathrm{N}_{\mathrm{sd}}:=1073 \quad \mathrm{kN}
$$

$$
\mathrm{N}_{\mathrm{G} . \mathrm{Sd}}:=0.6 \cdot \mathrm{N}_{\mathrm{Sd}}=643.8 \quad \mathrm{kN}
$$

\section{Determinação das propriedades geométricas da seção \\ Perfil Metálico:}

$$
\begin{aligned}
& \mathrm{h}:=\mathrm{d}-2 \cdot \mathrm{t}_{\mathrm{f}} \\
& \mathrm{A}_{\mathrm{a}}:=\left(2 \cdot \mathrm{bf} \cdot \mathrm{t}_{\mathrm{f}}+\mathrm{h} \cdot \mathrm{t}_{\mathrm{w}}\right) \cdot 0.01 \\
& \text { Iax }:=10^{-4} \cdot\left[2 \cdot \frac{\mathrm{bf} \cdot \mathrm{t}_{\mathrm{f}}{ }^{3}}{12}+2 \cdot \mathrm{bf} \cdot \mathrm{t}_{\mathrm{f}}\left(\frac{\mathrm{h}}{2}+\frac{\mathrm{t}_{\mathrm{f}}}{2}\right)^{2}+\frac{\mathrm{t}_{\mathrm{w}} \cdot \mathrm{h}^{3}}{12}\right] \\
& \text { Iay }:=10^{-4} \cdot\left(2 \cdot \frac{\mathrm{bf}^{3} \cdot \mathrm{t}_{\mathrm{f}}}{12}+\frac{\mathrm{t}_{\mathrm{w}}{ }^{3} \cdot \mathrm{h}}{12}\right) \\
& \mathrm{Z}_{\mathrm{ax}}:=\frac{\mathrm{bf}}{10} \cdot \frac{\mathrm{t}_{\mathrm{f}}}{10} \cdot\left(\frac{\mathrm{d}}{10}-\frac{\mathrm{t}_{\mathrm{f}}}{10}\right)+\left(\frac{\mathrm{d}}{10}-2 \cdot \frac{\mathrm{t}_{\mathrm{f}}}{10}\right)^{2} \cdot \frac{\mathrm{t}_{\mathrm{w}}}{40} \\
& \mathrm{Z}_{\text {ay }}:=\left(\frac{\mathrm{bf}}{10}\right)^{2} \cdot \frac{\mathrm{t}_{\mathrm{f}}}{20}+\frac{\left.\left[\left(\frac{\mathrm{d}}{10}\right)-2 \frac{\mathrm{t}_{\mathrm{f}}}{10}\right] \cdot\left(\frac{\mathrm{t}_{\mathrm{w}}}{10}\right)^{2}\right]}{4}
\end{aligned}
$$$$
\mathrm{h}=125
$$$$
\mathrm{mm}
$$$$
\mathrm{A}_{\mathrm{a}}=11.925
$$$$
\mathrm{cm}^{2}
$$$$
\operatorname{Iax}=378.3733
$$$$
\mathrm{cm}^{4}
$$

\section{Concreto:}

Largura total

Altura total

$$
\begin{gathered}
\text { Ac }:=\left(\text { bf } \cdot \frac{d}{10^{2}}\right)-A_{a} \\
\text { Icx }:=\left[\frac{\left(d^{3} \cdot \frac{b f}{12}\right)}{10^{4}}-\operatorname{Iax}\right]
\end{gathered}
$$

$\begin{array}{ll}\mathrm{bc}:=\mathrm{bf}-\mathrm{t}_{\mathrm{w}}=121.82 & \mathrm{~mm} \\ \mathrm{hc}:=\mathrm{d}-2 \cdot \mathrm{t}_{\mathrm{f}}=125 & \mathrm{~mm}\end{array}$

$\mathrm{Ac}=152.275$

$\mathrm{cm}^{2}$

IcX $=1982.7474$

$\mathrm{cm}^{4}$ 
Icy $:=\left[\frac{\left[\mathrm{bf}^{3} \cdot\left(\frac{\mathrm{d}}{12}\right)\right]}{10^{4}}-\right.$ Iay $]$

\section{Verificação da Armadura Mínima exigida}

$$
\begin{array}{lr}
\text { Ast }:=\mathrm{n} \cdot\left(\frac{\mathrm{dia}}{20}\right)^{2} \cdot(3.1415) & \text { Ast }=2.0106 \\
\text { Taxa }:=\frac{\text { Ast }}{\mathrm{Ac}} & \text { Taxa }=0.0132 \\
\text { taxa_armadura }:=\operatorname{if}\left[\left(\operatorname{Taxa}<\frac{0.3}{100}\right), \text { "Aumentar Armadura" , "Ok" }\right] &
\end{array}
$$$$
\mathrm{cm}^{2}
$$

\section{Determinação das propriedades mecânicas $\left(\mathrm{kN} / \mathrm{cm}^{2}\right)$}

Coeficiente de redução de fcd

$$
\begin{array}{ll}
\mathrm{f}_{\mathrm{yd}}:=\frac{\mathrm{f}_{\mathrm{yk}}}{1.0}=32.29 & \mathrm{f}_{\mathrm{cd}}:=\frac{\mathrm{f}_{\mathrm{ck}}}{1}=5.46 \quad \mathrm{f}_{\mathrm{cd} 1}:=\alpha \cdot \mathrm{f}_{\mathrm{cd}}=4.641 \quad \mathrm{f}_{\mathrm{sd}}:=\frac{\mathrm{f}_{\mathrm{sk}}}{1}=61 \\
\mathrm{Ec}:=3268.5 & \frac{\mathrm{kN}}{\mathrm{cm}^{2}}
\end{array}
$$

5 Verificação da Instabilidade Local

$$
\text { Instabilidade }:=\text { if }\left[\left(\frac{\frac{\mathrm{bf}}{10}}{\frac{\mathrm{t}_{\mathrm{f}}}{10}}\right)<1.49 \cdot \sqrt{\frac{\mathrm{Ea}}{\frac{\mathrm{f}_{\mathrm{yd}}}{10}}}\right], \text { "Ok" , "Não ok" }
$$

Instabilidade $=$ "Ok" $\alpha:=0.85$ 


\section{Resistência da Seção à Plastificação}

\subsection{Força de Compressão Resistente de Cáculo à Plastificação tota}

Área de armadura considerada no dimensionamento:

$\mathrm{N}_{\mathrm{pl} \cdot \mathrm{Rd}}:=\mathrm{f}_{\mathrm{yd}} \cdot \mathrm{A}_{\mathrm{a}}+\alpha \cdot \mathrm{f}_{\mathrm{cd}} \cdot \mathrm{Ac}+\mathrm{f}_{\mathrm{sd}} \cdot \mathrm{As}=1214.4131$

$\mathrm{N}_{\text {pl.R. }}:=\mathrm{f}_{\mathrm{yk}} \cdot \mathrm{A}_{\mathrm{a}}+\alpha \cdot \mathrm{f}_{\mathrm{ck}} \cdot \mathrm{Ac}+\mathrm{f}_{\mathrm{sk}} \cdot \mathrm{As}=1214.4131$

$\delta_{1}:=\frac{\mathrm{A}_{\mathrm{a}} \cdot \mathrm{f}_{\mathrm{yd}}}{\mathrm{N}_{\mathrm{pl} \cdot \mathrm{Rd}}}$

contribuição_perfil := if $\left[\left(\delta_{1}>0.2\right) \mathrm{e}\left(\delta_{1}<0.9\right)\right]$, "ok", "Não ok"]

$$
\begin{gathered}
\text { As }:=2.0106 \quad \mathrm{~cm} \\
\mathrm{~N}_{\text {pl.Rd }}=1214.4131 \quad \mathrm{kN} \\
\mathrm{N}_{\text {pl.R. }}=1214.4131 \quad \mathrm{kN} \\
\delta_{1}=0.3171
\end{gathered}
$$$$
\text { contribuição_perfil = "ok" }
$$

\subsection{Cálculo do Indice de Esbeltez Reduzido}

Coeficiente de Fluência do concreto

Momento de Inércia armadura - eixo x

Momento de Inércia armadura - eixo y

$\mathrm{E}_{\mathrm{c} . \mathrm{red}}:=\frac{\mathrm{Ec}}{1+\psi \cdot\left(\frac{\mathrm{N}_{\mathrm{G} . \mathrm{Sd}}}{\mathrm{N}_{\mathrm{sd}}}\right)}$

$\mathrm{EI}_{\mathrm{ex}}:=\mathrm{Ea} \cdot \mathrm{Iax}+0.6 \cdot \mathrm{E}_{\mathrm{c} . \mathrm{red}} \cdot \mathrm{Icx}+\mathrm{Es} \cdot \mathrm{Isx}$

$\mathrm{EI}_{\text {ey }}:=\mathrm{Ea} \cdot \mathrm{Iay}+0.6 \cdot \mathrm{E}_{\mathrm{c} . r e d} \cdot \mathrm{Icy}+\mathrm{Es} \cdot \mathrm{Isy}$

$\mathrm{Nex}:=\pi^{2} \cdot \frac{\mathrm{EI}_{\mathrm{ex}}}{(\mathrm{Kx} \cdot \mathrm{Lx})^{2}}$

Ney $:=\pi^{2} \cdot \frac{\mathrm{EI}_{\text {ey }}}{(\mathrm{Ky} \cdot \mathrm{Ly})^{2}}$

$\mathrm{Ne}:=\mid \begin{aligned} & \mathrm{Nex} \text { if } \mathrm{Nex} \leq \mathrm{Ney} \\ & \mathrm{Ney} \text { if } \mathrm{Nex}>\mathrm{Ney}\end{aligned}$

$$
\lambda_{\text {o.m.x }}:=\sqrt{\frac{\mathrm{N}_{\text {pl.R. }}}{\mathrm{Ne}}}
$$

\subsection{Cálculo do Fator de Redução}

$$
x:=\mid \begin{array}{ll}
0.658^{\lambda_{\text {o.m.x }}{ }^{2}} \text { if } \lambda_{\text {o.m.x }} \leq 1.5 \\
\frac{0.877}{\lambda_{\text {o.m.x }}^{2}} \text { if } \lambda_{\text {o.m.x }}>1.5
\end{array}
$$

$\mathrm{N}_{\mathrm{Rd}}:=\chi \cdot \mathrm{N}_{\mathrm{pl} . \mathrm{Rd}}$ $\psi:=2.5$

Isx $:=22.64$

$\mathrm{cm}^{4}$

Isy := 22.64

$\mathrm{cm}^{4}$

$\mathrm{E}_{\mathrm{c} . \mathrm{red}}=1307.4$

$\frac{\mathrm{kN}}{\mathrm{cm}^{2}}$

$\mathrm{EI}_{\mathrm{ex}}=9640020.8953$

$\mathrm{kN} \cdot \mathrm{cm}^{2}$

$\mathrm{EI}_{\text {ey }}=4180676.8395$

$\mathrm{kN} \cdot \mathrm{cm}^{2}$

$\mathrm{Nex}=9514.3193$

$\mathrm{kN}$

$\mathrm{Ney}=4126.1627$

$\mathrm{kN}$

$\lambda_{\text {o.m.x }}=0.5425$ $\chi=0.884$ 


\section{Planilha de Dimensionamento MODELO 2}

\section{Dados de entrada}

\section{Perfil Metálico:}

Altura total

Largura da mesa

Espessura da mesa

Espessura da alma

Armadura

Número de barras

Diametro da barra

$\begin{array}{ll}\mathrm{d}:=131.36 & \mathrm{~mm} \\ \mathrm{bf}:=125 & \mathrm{~mm} \\ \mathrm{t}_{\mathrm{f}}:=3.18 & \mathrm{~mm} \\ \mathrm{t}_{\mathrm{w}}:=3.18 & \mathrm{~mm}\end{array}$

$\mathrm{n}:=12$

Barras

$\mathrm{mm}$

\section{2 - Propriedades mecânicas dos Materiais $\left(\mathrm{kN} / \mathrm{cm}^{2}\right)$}

Resistência Característica do Aço

Resistência Característica do Concreto

Resistência Característica do Armadura

Módulo Elasticidade do Aço do Perfil

Módulo de Elasticidade do Aço da Armadura

$$
\mathrm{f}_{\mathrm{yk}}:=32.29 \quad \frac{\mathrm{kN}}{\mathrm{cm}^{2}}
$$

$$
\mathrm{f}_{\mathrm{ck}}:=5.46 \quad \frac{\mathrm{kN}}{\mathrm{cm}^{2}}
$$

$$
\mathrm{f}_{\mathrm{sk}}:=61 \quad \frac{\mathrm{kN}}{\mathrm{cm}^{2}}
$$

$$
\text { Es }:=22636 \quad \frac{\mathrm{kN}}{\mathrm{cm}^{2}}
$$

$\mathrm{Ea}:=20012.5 \quad \frac{\mathrm{kN}}{\mathrm{cm}^{2}}$

\section{3 - Comprimentos e coeficientes de flambagem}

Coeficiente de Flambagem em x

$$
\mathrm{Kx}:=1
$$

Coeficiente de Flambagem em y

$\mathrm{Ky}:=1$

Comprimento de Flambagem em $\mathrm{x}$ 


\section{4 - Solicitações de cálculo}

Momento Solicitante de Cálculo em x

$$
\mathrm{M}_{\mathrm{X} . \mathrm{Sd}}:=0 \quad \mathrm{kNcm}
$$

Momento Solicitante de Cálculo em y

$$
\mathrm{M}_{\mathrm{y} . \mathrm{Sd}}:=0 \quad \mathrm{kNcm}
$$

Normal Solicitante de Cálculo

$$
\mathrm{N}_{\mathrm{Sd}}:=834 \quad \mathrm{kN}
$$

Parcela da Normal devido a ação permanente e quase permanente

2 Determinação das propriedades geométricas da seção

\section{Perfil Metálico:}

$$
\begin{aligned}
& \mathrm{h}:=\mathrm{d}-2 \cdot \mathrm{t}_{\mathrm{f}} \\
& A_{a}:=\left(2 \cdot b f \cdot t_{f}+h \cdot t_{w}\right) \cdot 0.01 \\
& \mathrm{~h}=125 \\
& \mathrm{~mm} \\
& \mathrm{~A}_{\mathrm{a}}=11.925 \\
& \mathrm{~cm}^{2} \\
& \text { Iax }:=10^{-4} \cdot\left[2 \cdot \frac{\mathrm{bf} \cdot \mathrm{t}_{\mathrm{f}}{ }^{3}}{12}+2 \cdot \mathrm{bf} \cdot \mathrm{t}_{\mathrm{f}} \cdot\left(\frac{\mathrm{h}}{2}+\frac{\mathrm{t}_{\mathrm{f}}}{2}\right)^{2}+\frac{\mathrm{t}_{\mathrm{w}} \cdot \mathrm{h}^{3}}{12}\right] \\
& \operatorname{Iax}=378.3733 \\
& \mathrm{~cm}^{4} \\
& \text { Iay }:=10^{-4} \cdot\left(2 \cdot \frac{\mathrm{bf}^{3} \cdot \mathrm{t}_{\mathrm{f}}}{12}+\frac{\mathrm{t}_{\mathrm{w}}{ }^{3} \cdot \mathrm{h}}{12}\right) \\
& \text { Iay }=103.5491 \\
& \mathrm{~cm}^{4} \\
& \mathrm{Z}_{\mathrm{ax}}:=\frac{\mathrm{bf}}{10} \cdot \frac{\mathrm{t}_{\mathrm{f}}}{10} \cdot\left(\frac{\mathrm{d}}{10}-\frac{\mathrm{t}_{\mathrm{f}}}{10}\right)+\left(\frac{\mathrm{d}}{10}-2 \cdot \frac{\mathrm{t}_{\mathrm{f}}}{10}\right)^{2} \cdot \frac{\mathrm{t}_{\mathrm{w}}}{40} \\
& \mathrm{Z}_{\mathrm{ax}}=63.3734 \\
& \mathrm{~cm}^{3} \\
& \mathrm{Z}_{\text {ay }}:=\left(\frac{\mathrm{bf}}{10}\right)^{2} \cdot \frac{\mathrm{t}_{\mathrm{f}}}{20}+\frac{\left[\left[\left(\frac{\mathrm{d}}{10}\right)-2 \frac{\mathrm{t}_{\mathrm{f}}}{10}\right] \cdot\left(\frac{\mathrm{t}_{\mathrm{w}}}{10}\right)^{2}\right]}{4} \\
& Z_{\text {ay }}=25.1598 \\
& \mathrm{~cm}^{3}
\end{aligned}
$$

\section{Concreto:}

\section{Largura total}

Altura total

$$
\begin{gathered}
\text { Ac }:=\left(\mathrm{bf} \cdot \frac{\mathrm{d}}{10^{2}}\right)-\mathrm{A}_{\mathrm{a}} \\
\text { Icx }:=\left[\frac{\left(\mathrm{d}^{3} \cdot \frac{\mathrm{bf}}{12}\right)}{10^{4}}-\mathrm{Iax}\right]
\end{gathered}
$$

$\mathrm{bc}:=\mathrm{bf}-\mathrm{t}_{\mathrm{w}}=121.82$ 
Icy $:=\left[\frac{\left[\mathrm{bf}^{3} \cdot\left(\frac{\mathrm{d}}{12}\right)\right]}{10^{4}}-\right.$ Iay $]$

$\mathrm{Zc}_{\mathrm{x}}:=\left(\frac{\mathrm{bf}}{40}\right) \cdot\left(\frac{\mathrm{d}}{10}\right)^{2}-\mathrm{Z}_{\mathrm{ax}}$

$\mathrm{Zc}_{\mathrm{y}}:=\left(\frac{\mathrm{d}}{40}\right) \cdot\left(\frac{\mathrm{bf}}{10}\right)^{2}-\mathrm{z}_{\mathrm{ay}}$
Icy $=2034.4717$

$\mathrm{cm}^{4}$

$\mathrm{Zc}_{\mathrm{X}}=475.8594$

$\mathrm{cm}^{3}$

$Z c_{y}=487.9652$

3 Verificação da Armadura Mínima exigida

$$
\begin{array}{lr}
\text { Ast }:=\mathrm{n} \cdot\left(\frac{\mathrm{dia}}{20}\right)^{2} \cdot(3.1415) & \text { Ast }=1.6625 \\
\text { Taxa }:=\frac{\text { Ast }}{\mathrm{Ac}} & \text { Taxa }=0.0109 \\
\text { taxa_armadura }:=\operatorname{if}\left[\left(\text { Taxa }<\frac{0.3}{100}\right), \text { "Aumentar Armadura" , "Ok" }\right] &
\end{array}
$$$$
\mathrm{cm}^{2}
$$

\section{Determinação das propriedades mecânicas $\left(\mathrm{kN} / \mathrm{cm}^{2}\right)$}

Coeficiente de redução de fcd

$$
\begin{array}{ll}
\mathrm{f}_{\mathrm{yd}}:=\frac{\mathrm{f}_{\mathrm{yk}}}{1.0}=32.29 & \mathrm{f}_{\mathrm{cd}}:=\frac{\mathrm{f}_{\mathrm{ck}}}{1.0}=5.46 \quad \mathrm{f}_{\mathrm{cd} 1}:=\alpha \cdot \mathrm{f}_{\mathrm{cd}}=4.641 \quad \mathrm{f}_{\mathrm{sd}}:=\frac{\mathrm{f}_{\mathrm{sk}}}{1.0}=61 \\
\mathrm{Ec}:=4760 \cdot \frac{\sqrt{\mathrm{f}_{\mathrm{ck}} \cdot 10}}{10}=3517.2503 & \frac{\mathrm{kN}}{\mathrm{cm}^{2}}
\end{array}
$$

\section{Verificação da Instabilidade Local}

$$
\text { Instabilidade } \left.:=\mathrm{if}\left[\left(\frac{\frac{\mathrm{bf}}{10}}{\frac{\mathrm{t}_{\mathrm{f}}}{10}}\right)<1.49 \cdot \sqrt{\frac{\mathrm{Ea}}{\frac{\mathrm{f}_{\mathrm{yd}}}{10}}}\right], \text { "Ok" , "Não ok" }\right]
$$

Instabilidade $=$ "Ok" $\alpha:=0.85$ 


\section{Resistência da Seção à Plastificação}

\subsection{Força de Compressão Resistente de Cáculo à Plastificação total}

Área de armadura considerada no dimensionamento:

As $:=1.662$

$\mathrm{cm}^{2}$

$\mathrm{N}_{\text {pl.Rd }}:=\mathrm{f}_{\mathrm{yd}} \cdot \mathrm{A}_{\mathrm{a}}+\alpha \cdot \mathrm{f}_{\mathrm{cd}} \cdot \mathrm{Ac}+\mathrm{f}_{\mathrm{sd}} \cdot \mathrm{As}=1193.1485$

$\mathrm{N}_{\text {pl.Rd }}=1193.1485 \quad \mathrm{kN}$

$\mathrm{N}_{\text {pl.R. }}:=\mathrm{f}_{\mathrm{yk}} \cdot \mathrm{A}_{\mathrm{a}}+\alpha \cdot \mathrm{f}_{\mathrm{ck}} \cdot \mathrm{Ac}+\mathrm{f}_{\mathrm{sk}} \cdot \mathrm{As}=1193.1485$

$\mathrm{N}_{\text {pl.R. }}=1193.1485 \quad \mathrm{kN}$

$\delta_{1}:=\frac{\mathrm{A}_{\mathrm{a}} \cdot \mathrm{f}_{\mathrm{yd}}}{\mathrm{N}_{\mathrm{pl} \cdot \mathrm{Rd}}}$

$\delta_{1}=0.3227$

contribuição_perfil := if $\left[\left(\delta_{1}>0.2\right) \mathrm{e}\left(\delta_{1}<0.9\right)\right]$, "ok" , "Não ok"]

contribuição_perfil = "ok"

\subsection{Cálculo do Índice de Esbeltez Reduzido}

Coeficiente de Fluência do concreto

Momento de Inércia armadura - eixo $\mathrm{x}$

Momento de Inércia armadura - eixo y

$\mathrm{E}_{\mathrm{c} . \mathrm{red}}:=\frac{\mathrm{Ec}}{1+\psi \cdot\left(\frac{\mathrm{N}_{\mathrm{G} . \mathrm{Sd}}}{\mathrm{N}_{\mathrm{sd}}}\right)}$

$\mathrm{EI}_{\mathrm{ex}}:=\mathrm{Ea} \cdot \mathrm{Iax}+0.6 \cdot \mathrm{E}_{\mathrm{c} \cdot \mathrm{red}} \cdot \mathrm{Icx}+\mathrm{Es} \cdot \mathrm{Isx}$

$\mathrm{EI}_{\mathrm{ey}}:=\mathrm{Ea} \cdot \mathrm{Iay}+0.6 \cdot \mathrm{E}_{\mathrm{c} \cdot \mathrm{red}} \cdot \mathrm{Icy}+\mathrm{Es} \cdot \mathrm{Isy}$

Nex $:=\pi^{2} \cdot \frac{\mathrm{EI}_{\mathrm{ex}}}{(\mathrm{Kx} \cdot \mathrm{Lx})^{2}}$

Ney $:=\pi^{2} \cdot \frac{\mathrm{EI}_{\text {ey }}}{(\mathrm{Ky} \cdot \mathrm{Ly})^{2}}$

$\mathrm{Ne}:=\mid \begin{array}{ll}\mathrm{Nex} & \text { if Nex } \leq \mathrm{Ney} \\ \mathrm{Ney} & \text { if } \mathrm{Nex}>\mathrm{Ney}\end{array}$

$\lambda_{\text {o.m.x }}:=\sqrt{\frac{\mathrm{N}_{\mathrm{pl} . \mathrm{R} .}}{\mathrm{Ne}}}$

\subsection{Cálculo do Fator de Redução}

$$
\chi:=\mid \begin{array}{ll}
0.658^{\lambda_{\text {o.m.x }}{ }^{2}} \text { if } \lambda_{\text {o.m.x }} \leq 1.5 \\
\frac{0.877}{\lambda_{\text {o.m.x }}^{2}} \text { if } \lambda_{\text {o.m.x }}>1.5
\end{array}
$$

$\mathrm{N}_{\mathrm{Rd}}:=\chi \cdot \mathrm{N}_{\mathrm{pl} \cdot \mathrm{Rd}}$ $\psi:=2.5$

Isx $:=15.0$

$\mathrm{cm}^{4}$

Isy := 16.13

$\mathrm{cm}^{4}$

$\mathrm{E}_{\mathrm{c} . \mathrm{red}}=1406.9001$

$\mathrm{kN}$

$\mathrm{EI}_{\mathrm{ex}}=9585678.3727$

$\mathrm{kN} \cdot \mathrm{cm}^{2}$

$\mathrm{EI}_{\text {ey }}=4154774.5821 \quad \mathrm{kN} \cdot \mathrm{cm}^{2}$

$\mathrm{Nex}=9460.6853$

$\mathrm{kN}$

Ney $=4100.5982$

$\mathrm{kN}$

$\mathrm{Ne}=4100.5982$

$\mathrm{kN}$

$\lambda_{\text {o.m.x }}=0.5394$ 


\section{Planilha de Dimensionamento de Pilares Mistos MODELO 3}

\section{Dados de entrada}

\section{Perfil Metálico:}

$\begin{array}{lll}\text { Altura total } & \mathrm{d}:=131.36 & \mathrm{~mm} \\ \begin{array}{l}\text { Largura da mesa } \\ \text { Espessura da mesa }\end{array} & \mathrm{t}_{\mathrm{f}}:=3.18 & \mathrm{~mm} \\ \text { Espessura da alma } & \mathrm{t}_{\mathrm{w}}:=3.18 & \mathrm{~mm} \\ \text { Armadura } & & \mathrm{nm}:=0 \\ \text { Número de barras } & \text { dia }:=0 \quad \text { Barras } \\ \text { Diametro da barra } & \mathrm{mm}\end{array}$

\section{2 - Propriedades mecânicas dos Materiais $\left(\mathrm{kN} / \mathrm{cm}^{2}\right)$}

Resistência Característica do Aço

$\mathrm{f}_{\mathrm{yk}}:=32.29 \quad \frac{\mathrm{kN}}{\mathrm{cm}^{2}}$

Resistência Característica do Concreto

$\mathrm{f}_{\mathrm{ck}}:=4.71 \quad \frac{\mathrm{kN}}{\mathrm{cm}^{2}}$

Resistência Característica do Armadura

$\mathrm{f}_{\mathrm{sk}}:=61 \quad \frac{\mathrm{kN}}{\mathrm{cm}^{2}}$

Módulo Elasticidade do Aço do Perfil

Es $:=22636 \quad \frac{\mathrm{kN}}{\mathrm{cm}^{2}}$

Módulo de Elasticidade do Aço da Armadura

$\mathrm{Ea}:=20012.5 \quad \frac{\mathrm{kN}}{\mathrm{cm}^{2}}$

\section{3 - Comprimentos e coeficientes de flambagem}

Coeficiente de Flambagem em $\mathrm{x}$

$\mathrm{Kx}:=1$

Coeficiente de Flambagem em y

$\mathrm{Ky}:=1$

Comprimento de Flambagem em $\mathbf{x}$

$\mathrm{Lx}:=100 \quad \mathrm{~cm}$

Comprimento de Flambagem em y

Ly $:=100 \quad \mathrm{~cm}$




\section{4 - Solicitações de cálculo}

Momento Solicitante de Cálculo em $\mathrm{x}$

$$
\mathrm{M}_{\mathrm{x} . \mathrm{Sd}}:=0 \quad \mathrm{kNcm}
$$

Momento Solicitante de Cálculo em y

$$
\mathrm{M}_{\mathrm{y} \cdot \mathrm{Sd}}:=600 \quad \mathrm{kNcm}
$$

Normal Solicitante de Cálculo

$$
\mathrm{N}_{\mathrm{Sd}}:=600 \quad \mathrm{kN}
$$

Parcela da Normal devido a ação permanente e quase permanente

$$
\mathrm{N}_{\mathrm{G} . S d}:=0.6 \cdot \mathrm{N}_{\mathrm{sd}}=360 \quad \mathrm{kN}
$$

\section{Determinação das propriedades geométricas da seção}

$$
\begin{array}{lll}
\mathrm{h}:=\mathrm{d}-2 \cdot \mathrm{t}_{\mathrm{f}} & \mathrm{h}=125 & \mathrm{~mm} \\
\mathrm{~A}_{\mathrm{a}}:=\left(2 \cdot \mathrm{bf} \cdot \mathrm{t}_{\mathrm{f}}+\mathrm{h} \cdot \mathrm{t}_{\mathrm{w}}\right) \cdot 0.01 & \mathrm{~A}_{\mathrm{a}}=11.925 & \mathrm{~cm}^{2} \\
\text { Iax }:=10^{-4} \cdot\left[2 \cdot \frac{\mathrm{bf} \cdot \mathrm{t}_{\mathrm{f}}{ }^{3}}{12}+2 \cdot \mathrm{bf} \cdot \mathrm{t}_{\mathrm{f}} \cdot\left(\frac{\mathrm{h}}{2}+\frac{\mathrm{t}_{\mathrm{f}}}{2}\right)^{2}+\frac{\mathrm{t}_{\mathrm{w}} \cdot \mathrm{h}^{3}}{12}\right] & \text { Iax }=378.3733 & \mathrm{~cm}^{4} \\
\text { Iay }:=10^{-4} \cdot\left(2 \cdot \frac{\mathrm{bf}^{3} \cdot \mathrm{t}_{\mathrm{f}}}{12}+\frac{\mathrm{t}_{\mathrm{w}}{ }^{3} \cdot \mathrm{h}}{12}\right) & \text { Iay }=103.5491 & \mathrm{~cm}^{4} \\
\mathrm{Z}_{\mathrm{ax}}:=\frac{\mathrm{bf}}{10} \cdot \frac{\mathrm{t}_{\mathrm{f}}}{10} \cdot\left(\frac{\mathrm{d}}{10}-\frac{\mathrm{t}_{\mathrm{f}}}{10}\right)+\left(\frac{\mathrm{d}}{10}-2 \cdot \frac{\mathrm{t}_{\mathrm{f}}}{10}\right)^{2} \cdot \frac{\mathrm{t}_{\mathrm{w}}}{40} & \mathrm{Z}_{\mathrm{ax}}=63.3734 & \mathrm{~cm}^{3} \\
\mathrm{Z}_{\text {ay }}:=\left(\frac{\mathrm{bf}}{10}\right)^{2} \cdot \frac{\mathrm{t}_{\mathrm{f}}}{20}+\frac{\left.\left(\left[\frac{\mathrm{d}}{10}\right)-2 \frac{\mathrm{t}_{\mathrm{f}}}{10}\right] \cdot\left(\frac{\mathrm{t}_{\mathrm{w}}}{10}\right)^{2}\right]}{4} & &
\end{array}
$$

\section{Concreto:}

Largura total

Altura total

$$
\begin{gathered}
\text { Ac }:=\left(b f \cdot \frac{d}{10^{2}}\right)-A_{a} \\
\operatorname{Icx}:=\left[\frac{\left(d^{3} \cdot \frac{b f}{12}\right)}{10^{4}}-\operatorname{Iax}\right]
\end{gathered}
$$

$\mathrm{bc}:=\mathrm{bf}-\mathrm{t}_{\mathrm{w}}=121.82$

hc $:=\mathrm{d}-2 \cdot \mathrm{t}_{\mathrm{f}}=125$

$\mathrm{mm}$

$\mathrm{Ac}=152.275$

$\mathrm{cm}^{2}$

Icx $=1982.7474$

$\mathrm{cm}^{4}$ 
Icy $:=\left[\frac{\left[\mathrm{bf}^{3} \cdot\left(\frac{\mathrm{d}}{12}\right)\right]}{10^{4}}-\right.$ Iay $]$

$\mathrm{Zc}_{\mathrm{x}}:=\left(\frac{\mathrm{bf}}{40}\right) \cdot\left(\frac{\mathrm{d}}{10}\right)^{2}-\mathrm{Z}_{\mathrm{ax}}$

$Z_{c_{y}}:=\left(\frac{d}{40}\right) \cdot\left(\frac{b f}{10}\right)^{2}-Z_{a y}$
Icy $=2034.4717$

$\mathrm{cm}^{4}$

$Z c_{x}=475.8594$

$\mathrm{cm}^{3}$

\section{Verificação da Armadura Mínima exigida}

$$
\begin{array}{ll}
\text { Ast }:=\mathrm{n} \cdot\left(\frac{\mathrm{dia}}{20}\right)^{2} \cdot(3.1415) & \text { Ast }=0 \\
\text { Taxa }:=\frac{\text { Ast }}{\mathrm{Ac}} & \text { Taxa }=0 \\
\text { taxa_armadura }:=\operatorname{iff}\left[\left(\text { Taxa }<\frac{0.3}{100}\right), \text { "Aumentar Armadura" ,Ok" }\right] &
\end{array}
$$$$
\mathrm{cm}^{2}
$$ 


\section{Determinação das propriedades mecânicas $\left(\mathrm{kN} / \mathrm{cm}^{2}\right)$}

Coeficiente de redução de fcd

$f_{y d}:=\frac{f_{y k}}{1 .}=32.29$

$\mathrm{f}_{\mathrm{cd}}:=\frac{\mathrm{f}_{\mathrm{ck}}}{1}=4.71$

$\frac{\mathrm{kN}}{\mathrm{cm}^{2}}$

Ec $:=3063.35$ $\alpha:=0.85$

$f_{\text {cd } 1}:=\alpha \cdot f_{c d}=4.0035$

$f_{s d}:=\frac{f_{s k}}{1 .}=61$

\section{Cálculo do Módulos Plásticos:}

\section{1 - Eixo x}

\subsection{1 -Posição da Linha Neutra}

Soma das áreas das barras da armadura da região de altura $2 \mathrm{hn}$.

Asnx : $=0 \quad \mathrm{~cm}^{2}$

Atribuir um valor para armadura e verificar se corresponde a região $2 \mathrm{hn}$ que será calculada a seguir.

$$
\begin{aligned}
& \operatorname{hnx}:=\mid \mathrm{Z} \leftarrow\left[\frac{\mathrm{Ac} \cdot \mathrm{f}_{\mathrm{cd} 1}-\mathrm{Asnx} \cdot\left(2 \cdot \mathrm{f}_{\mathrm{sd}}-\mathrm{f}_{\mathrm{cdl}}\right)}{2 \cdot \frac{\mathrm{bc}}{10} \cdot \mathrm{f}_{\mathrm{cd} 1}+2 \cdot \frac{\mathrm{t}_{\mathrm{w}}}{10} \cdot\left(2 \cdot \mathrm{f}_{\mathrm{yd}}-\mathrm{f}_{\mathrm{cd} 1}\right)}\right] \text { if } \mathrm{Z} \leq 0.5 \cdot \frac{\mathrm{d}}{10}-\frac{\mathrm{t}_{\mathrm{f}}}{10} \\
& \left\{\begin{array}{l}
Z \leftarrow \frac{{ }^{2} \cdot f_{c d 1}-A s n x \cdot\left(2 \cdot f_{s d}-f_{c d 1}\right)+\left(\frac{b f}{10}-\frac{t_{w}}{10}\right) \cdot\left(\frac{d}{10}-2 \cdot \frac{t_{f}}{10}\right) \cdot\left(2 \cdot f_{y d}-f_{c d 1}\right)}{2 \cdot \frac{b c}{10} \cdot f_{c d 1}+2 \cdot \frac{b f}{10} \cdot\left(2 \cdot f_{y d}-f_{c d 1}\right)} \text { if }\left(Z>0.5 \cdot \frac{d}{10}-\frac{t_{f}}{10}\right) e\left(Z \leq 0.5 \cdot \frac{d}{10}\right) \\
Z \leftarrow\left[\frac{A c \cdot f_{c d 1}-A s n x \cdot\left(2 \cdot f_{s d}-f_{c d 1}\right)-A_{a} \cdot\left(2 \cdot f_{y d}-f_{c d 1}\right)}{2 \cdot \frac{b c}{10} \cdot f_{c d 1}}\right] \text { if }\left(Z>0.5 \cdot \frac{d}{10}\right) e\left(Z \leq 0.5 \cdot \frac{h c}{10}\right)
\end{array}\right. \\
& \text { hnx }=4.4804 \quad \mathrm{~cm}
\end{aligned}
$$

\subsection{2 -Cálculo dos Módulos Plásticos do Aço e Concreto}

$$
\begin{aligned}
& \operatorname{Zan}_{x}:=\mid \frac{{ }_{w}}{10} \cdot \text { hnx }^{2} \text { if } \operatorname{hnx} \leq 0.5 \cdot \frac{\mathrm{d}}{10}-\frac{\mathrm{t}_{\mathrm{f}}}{10} \\
& \begin{array}{l}
\frac{b f}{10} \cdot h n x^{2}-\frac{\left(\frac{b f}{10}-\frac{t_{w}}{10}\right) \cdot\left(\frac{d}{10}-2 \cdot \frac{t_{f}}{10}\right)^{2}}{4} \text { if }\left(\operatorname{hnx}>0.5 \cdot \frac{d}{10}-\frac{t_{f}}{10}\right) e\left(h n x \leq 0.5 \cdot \frac{d}{10}\right) \\
Z_{a x} \text { if }\left(h n x>0.5 \cdot \frac{d}{10}\right) \cdot\left(h n x \leq 0.5 \cdot \frac{h c}{10}\right)
\end{array} \\
& \operatorname{Zan}_{\mathrm{x}}=6.3834 \quad \mathrm{~cm}^{3} \\
& Z_{\text {snx }}:=0 \quad \mathrm{~cm}^{3} \quad \text { Calcular pelas Eq: } Z_{\text {snx }}=\Sigma\left|A_{\text {sni }^{*}}{ }^{*} e_{\mathrm{i}}\right| \\
& \mathrm{Zen}_{\mathrm{X}}:=\mid \begin{array}{l}
\mathrm{A} \leftarrow\left(\frac{\mathrm{bc}}{10} \cdot \mathrm{hnx}^{2}-\mathrm{Zan}_{\mathrm{x}}-\mathrm{Zsnx}\right) \text { if } \mathrm{A} \geq 0 \\
\mathrm{~A} \leftarrow 0 \text { if } \mathrm{A}<0
\end{array}
\end{aligned}
$$




\section{2 - Eixo y}

\subsection{1 -Posição da Linha Neutra}

Soma das áreas das barras da armadura da região de altura $2 \mathrm{hn}$.

Atribuir um valor para armadura e verificar se corresponde a região $2 \mathrm{hn}$ que será calculada a seguir.

$$
\text { hny }:=\left\{\begin{array}{l}
\mathrm{Z} \leftarrow\left[\frac{\mathrm{Ac} \cdot \mathrm{f}_{\mathrm{cd} 1}-\mathrm{Asny} \cdot\left(2 \cdot \mathrm{f}_{\mathrm{sd}}-\mathrm{f}_{\mathrm{cd} 1}\right)}{2 \cdot \frac{\mathrm{hc}}{10} \cdot \mathrm{f}_{\mathrm{cd} 1}+2 \cdot \frac{\mathrm{d}}{10} \cdot\left(2 \cdot \mathrm{f}_{\mathrm{yd}}-\mathrm{f}_{\mathrm{cd} 1}\right)}\right] \text { if } \mathrm{Z} \leq 0.5 \cdot \frac{\mathrm{w}}{10} \\
\mathrm{Z} \leftarrow \frac{\mathrm{Ac} \cdot \mathrm{f}_{\mathrm{cd} 1}-\text { Asny } \cdot\left(2 \cdot \mathrm{f}_{\mathrm{sd}}-\mathrm{f}_{\mathrm{cd} 1}\right)+\left(\frac{\mathrm{t}}{10}\right) \cdot\left(2 \cdot \frac{\mathrm{t}_{\mathrm{f}}}{10}-\frac{\mathrm{d}}{10}\right) \cdot\left(2 \cdot \mathrm{f}_{\mathrm{yd}}-\mathrm{f}_{\mathrm{cd} 1}\right)}{2 \cdot \frac{\mathrm{hc}}{10} \cdot \mathrm{f}_{\mathrm{cd} 1}+4 \cdot \frac{\mathrm{t}_{\mathrm{f}}}{10} \cdot\left(2 \cdot \mathrm{f}_{\mathrm{yd}}-\mathrm{f}_{\mathrm{cd} 1}\right)} \text { if }\left(\mathrm{Z}>0.5 \cdot \frac{\mathrm{w}}{10}\right) \mathrm{e}\left(\mathrm{Z} \leq 0.5 \cdot \frac{\mathrm{bf}}{10}\right) \\
\mathrm{Z} \leftarrow\left[\frac{\mathrm{Ac} \cdot \mathrm{f}_{\mathrm{cd} 1}-\text { Asny } \cdot\left(2 \cdot \mathrm{f}_{\mathrm{sd}}-\mathrm{f}_{\mathrm{cd} 1}\right)-\mathrm{A}_{\mathrm{a}} \cdot\left(2 \cdot \mathrm{f}_{\mathrm{yd}}-\mathrm{f}_{\mathrm{cd} 1}\right)}{2 \cdot \frac{\mathrm{hc}}{10} \cdot \mathrm{f}_{\mathrm{cd} 1}}\right] \text { if }\left(\mathrm{Z}>0.5 \cdot \frac{\mathrm{bf}}{10}\right) \mathrm{e}\left(\mathrm{Z} \leq 0.5 \cdot \frac{\mathrm{bc}}{10}\right)
\end{array}\right.
$$$$
\text { hny }=2.0822 \quad \mathrm{~cm}
$$

\subsection{2 -Cálculo dos Módulos Plásticos do Aço e Concreto}

$$
\begin{aligned}
& \operatorname{Zan}_{\mathrm{y}}:=\mid \begin{array}{l}
\frac{\mathrm{d}}{10} \cdot \text { hny }^{2} \text { if } \text { hny } \leq 0.5 \cdot \frac{\mathrm{t}_{\mathrm{w}}}{10} \\
2 \frac{\mathrm{t}_{\mathrm{f}}}{10} \cdot \text { hny }^{2}+\frac{\left(\frac{\mathrm{t}_{\mathrm{w}}}{10}\right)^{2} \cdot\left(\frac{\mathrm{d}}{10}-2 \cdot \frac{\mathrm{t}_{\mathrm{f}}}{10}\right)}{4} \text { if }\left(\text { hny }>0.5 \cdot \frac{\mathrm{t}_{\mathrm{w}}}{10}\right) \mathrm{e}\left(\text { hny } \leq 0.5 \cdot \frac{\mathrm{bf}}{10}\right) \\
\left.\mathrm{Z}_{\text {ay }} \text { if (hny }>0.5 \cdot \mathrm{bf}\right) \mathrm{e}(\text { hny } \leq 0.5 \cdot \mathrm{bc})
\end{array} \\
& \operatorname{Zan}_{\mathrm{y}}=3.0734 \quad \mathrm{~cm}^{3} \\
& \text { Zsny }:=0 \quad \mathrm{~cm}^{3} \quad \text { Calcular pelas Eq: } Z_{\text {snx }}=\Sigma\left|A_{\text {sni }}{ }^{*} e_{\text {yi }}\right| \\
& \mathrm{Zcn}_{\mathrm{y}}:=\mid \begin{array}{l}
\mathrm{A} \leftarrow\left(\frac{\mathrm{bc}}{10} \cdot \frac{\mathrm{hny}^{2}}{4}-\mathrm{Zan}_{\mathrm{y}}-\mathrm{Zsny}\right) \text { if } \mathrm{A} \geq 0 \\
\mathrm{~A} \leftarrow 0 \text { if } \mathrm{A}<0
\end{array} \\
& \mathrm{Zcn}_{\mathrm{y}}=10.1304 \quad \mathrm{~cm}^{3}
\end{aligned}
$$

\section{Verificação da Instabilidade Local}

$$
\text { Instabilidade } \left.:=\text { if }\left[\left(\frac{\frac{\mathrm{bf}}{10}}{\frac{\mathrm{t}_{\mathrm{f}}}{10}}\right)<1.49 \cdot \sqrt{\frac{\mathrm{Ea}}{\frac{\mathrm{f}_{\mathrm{yd}}}{10}}}\right], \text { "Ok" , "Não ok" }\right]
$$




\section{Resistência da Seção à Plastificação \\ Flexo-Compressão}

\subsection{Força de Compressão Resistente de Cáculo à Plastificação total}

$$
\begin{aligned}
& \text { Área de armadura considerada no dimensionamento: } \\
& \text { As }:=0 \\
& \mathrm{~cm}^{2} \\
& \mathrm{~N}_{\text {pl.Rd }}:=\mathrm{f}_{\mathrm{yd}} \cdot \mathrm{A}_{\mathrm{a}}+\alpha \cdot \mathrm{f}_{\mathrm{cd}} \cdot \mathrm{Ac}+\mathrm{f}_{\mathrm{sd}} \cdot \mathrm{As}=994.6912 \\
& \mathrm{~N}_{\text {pl.Rd }}=994.6912 \quad \mathrm{kN} \\
& N_{\text {pl.R. }}:=f_{y k} \cdot A_{a}+\alpha \cdot f_{c k} \cdot A c+f_{s k} \cdot A s=994.6912 \\
& \mathrm{~N}_{\text {pl.R. }}=994.6912 \\
& \mathrm{kN} \\
& \delta_{1}:=\frac{\mathrm{A}_{\mathrm{a}} \cdot \mathrm{f}_{\mathrm{yd}}}{\mathrm{N}_{\mathrm{pl} . \mathrm{Rd}}} \\
& \delta_{1}=0.3871 \\
& \text { contribuição_perfil := if } \left.\left[\left(\delta_{1}>0.2\right) \mathrm{e}\left(\delta_{1}<0.9\right)\right] \text {, "ok" , "Não ok" }\right] \\
& \text { contribuição_perfil = "ok" }
\end{aligned}
$$

\subsection{Cálculo do Indice de Esbeltez Reduzido}

Coeficiente de Fluência do concreto

Momento de Inércia - eixo $\mathrm{x}$

Momento de Inércia - eixo y

$$
\mathrm{E}_{\text {c.red }}:=\frac{\mathrm{Ec}}{1+\psi \cdot\left(\frac{\mathrm{N}_{\mathrm{G} . S d}}{\mathrm{~N}_{\mathrm{sd}}}\right)}
$$

$\mathrm{EI}_{\mathrm{ex}}:=\mathrm{Ea} \cdot \mathrm{Iax}+0.6 \cdot \mathrm{E}_{\mathrm{c} . \mathrm{red}} \cdot \mathrm{Icx}+\mathrm{Es} \cdot \mathrm{Isx}$

$\mathrm{EI}_{\mathrm{ey}}:=\mathrm{Ea} \cdot \mathrm{Iay}+0.6 \cdot \mathrm{E}_{\mathrm{c} . \mathrm{red}} \cdot \mathrm{Icy}+$ Es·Isy

$\mathrm{Nex}:=\pi^{2} \cdot \frac{\mathrm{EI}_{\mathrm{ex}}}{(\mathrm{Kx} \cdot \mathrm{Lx})^{2}}$

Ney $:=\pi^{2} \cdot \frac{\mathrm{EI}_{\mathrm{ey}}}{(\mathrm{Ky} \cdot \mathrm{Ly})^{2}}$

$\mathrm{Ne}:=\mid \begin{array}{ll}\mathrm{Nex} & \text { if Nex } \leq \mathrm{Ney} \\ \mathrm{Ney} & \text { if Nex }>\text { Ney }\end{array}$

$\lambda_{\text {o.m.x }}:=\sqrt{\frac{\mathrm{N}_{\text {pl.R. }}}{\mathrm{Ne}}}$ $\psi:=2.5$

Isx $:=0$

$\mathrm{cm}^{4}$

Isy := 0

$\mathrm{cm}^{4}$

$\mathrm{E}_{\mathrm{c} . \mathrm{red}}=1225.34$

$\frac{\mathrm{kN}}{\mathrm{cm}^{2}}$

$\mathrm{EI}_{\text {ex }}=9029919.3045 \quad \mathrm{kN} \cdot \mathrm{cm}^{2}$

$\mathrm{EI}_{\text {ey }}=3568028.5503 \quad \mathrm{kN} \cdot \mathrm{cm}^{2}$

$\mathrm{Nex}=8912.1731$

$\mathrm{kN}$

$\mathrm{Ney}=3521.503$

$\mathrm{kN}$

$\mathrm{Ne}=3521.503$

$\mathrm{kN}$

$\lambda_{\text {o.m.x }}=0.5315$ 


\subsection{Cálculo do Fator de Redução}

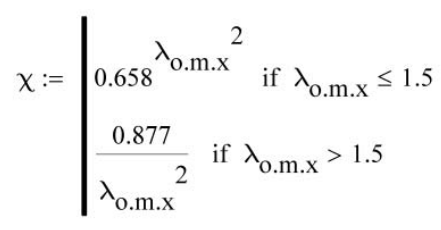

$\mathrm{N}_{\mathrm{Rd}}:=\chi \cdot \mathrm{N}_{\mathrm{pl} . \mathrm{Rd}}$ $\chi=0.888$

$\mathrm{N}_{\mathrm{Rd}}=883.7796$
$\mathrm{kN}$

\subsection{Modelo I}

\subsubsection{Momentos fletores de plastificação de Cálculo}

Admitindo-se: Momento Resistente Plástico da Armadura- eixo $\mathrm{x}$

$\mathrm{Z}_{\mathrm{S} . \mathrm{X}}:=0$

$\mathrm{cm}^{3}$ Momento Resistente Plástico- eixo y

$\mathrm{M}_{\text {pl.x.Rd }}:=\mathrm{f}_{\mathrm{yd}} \cdot\left(\mathrm{Z}_{\mathrm{ax}}-\mathrm{Zan}_{\mathrm{x}}\right)+0.5 \cdot \mathrm{f}_{\mathrm{cd} 1} \cdot\left(\mathrm{Zc}_{\mathrm{x}}-\mathrm{Zcn}_{\mathrm{x}}\right)+\mathrm{f}_{\mathrm{sd}} \cdot\left(\mathrm{Z}_{\mathrm{s} \cdot \mathrm{x}}-\mathrm{Zsnx}\right)$

$$
\mathrm{M}_{\text {pl.x.Rd }}=2316.036
$$

$M_{\text {pl.y.Rd }}:=f_{y d} \cdot\left(Z_{a y}-Z_{a n}\right)+0.5 \cdot f_{c d l} \cdot\left(Z_{y}-Z_{c n}\right)+f_{s d} \cdot\left(Z_{s \cdot y}-Z s n y\right)$

$$
\mathrm{M}_{\text {pl.y.Rd }}=1669.6742 \quad \mathrm{kN} \cdot \mathrm{cm}
$$

$\mathrm{M}_{\mathrm{x} \cdot \mathrm{Rd}}:=\mathrm{M}_{\mathrm{pl} \cdot \mathrm{x} \cdot \mathrm{Rd}} \quad \mathrm{M}_{\mathrm{y} \cdot \mathrm{Rd}}:=\mathrm{M}_{\mathrm{pl} \cdot \mathrm{y} \cdot \mathrm{Rd}}$

$\mathrm{M}_{\text {max.pl.x.Rd }}:=\mathrm{f}_{\mathrm{yd}} \cdot \mathrm{Z}_{\mathrm{ax}}+0.5 \cdot \mathrm{f}_{\mathrm{cd} 1} \cdot \mathrm{Zc}_{\mathrm{x}}+\mathrm{f}_{\mathrm{sd}} \cdot \mathrm{Z}_{\mathrm{s} . \mathrm{x}}$

$\mathrm{M}_{\text {max.pl.y.Rd }}:=\mathrm{f}_{\mathrm{yd}} \cdot \mathrm{Z}_{\text {ay }}+0.5 \cdot \mathrm{f}_{\mathrm{cd} 1} \cdot \mathrm{Zc}_{\mathrm{y}}+\mathrm{f}_{\text {sd }} \cdot \mathrm{Z}_{\text {s.y }}$

\subsubsection{Equação de Interação}

$$
\text { InteraçãoI : }=\begin{array}{ll}
{\left[\left(\frac{\mathrm{N}_{\mathrm{sd}}}{\mathrm{N}_{\mathrm{Rd}}}\right)+\frac{8}{9} \cdot\left[\left(\frac{\mathrm{M}_{\mathrm{x} \cdot \mathrm{Sd}}}{\mathrm{M}_{\mathrm{x} \cdot \mathrm{Rd}}}\right)+\left(\frac{\mathrm{M}_{\mathrm{y} \cdot \mathrm{Sd}}}{\mathrm{M}_{\mathrm{y} \cdot \mathrm{Rd}}}\right)\right]\right] \text { if }\left(\frac{\mathrm{N}_{\mathrm{sd}}}{\mathrm{N}_{\mathrm{Rd}}} \geq 0.2\right)} \\
{\left[\left(\frac{\mathrm{N}_{\mathrm{sd}}}{2 \mathrm{~N}_{\mathrm{Rd}}}\right)+\left[\left(\frac{\mathrm{M}_{\mathrm{x} \cdot \mathrm{Sd}}}{\mathrm{M}_{\mathrm{x} \cdot \mathrm{Rd}}}\right)+\left(\frac{\mathrm{M}_{\mathrm{y} \cdot \mathrm{Sd}}}{\mathrm{M}_{\mathrm{y} \cdot \mathrm{Rd}}}\right)\right]\right] \text { if }\left(\frac{\mathrm{N}_{\mathrm{sd}}}{\mathrm{N}_{\mathrm{Rd}}}<0.2\right)}
\end{array}
$$

InteraçãoI $=0.9983$ 


\section{Planilha de Dimensionamento de Pilares Mistos MODELO 3 - Modelo de Cálculo II}

Momento Solicitante de Cálculo em x

Momento Solicitante de Cálculo em y

Normal Solicitante de Cálculo

Parcela da Normal devido a ação

permanente e quase permanente

\subsection{Modelo II}

7.5.1 Cálculo de $M_{c, x}$ e $M_{c, y}$

$$
\begin{aligned}
& \mathrm{M}_{\mathrm{c} . \mathrm{x}}:=0.9 \cdot \mathrm{M}_{\text {pl.x.Rd }} \\
& \mathrm{M}_{\mathrm{c} . \mathrm{y}}:=0.9 \cdot \mathrm{M}_{\text {pl.y.Rd }}
\end{aligned}
$$

$\mathrm{kNcm}$

$$
\mathrm{M}_{\mathrm{X} . S \mathrm{~d}}:=0
$$

$$
\mathrm{M}_{\mathrm{y} . \mathrm{Sd}}:=790
$$$$
\mathrm{N}_{\mathrm{sd}}:=790
$$

$\mathrm{kNcm}$

$\mathrm{N}_{\mathrm{G} . S d}:=0.6 \cdot \mathrm{N}_{\mathrm{Sd}}=474$ $\mathrm{kN}$

\subsubsection{Cálculo de $\mu_{x}$ e $\mu_{y}$}

$$
\begin{aligned}
& \mathrm{M}_{\mathrm{d} . \mathrm{x}}:=\mid \begin{array}{l}
\mathrm{h} 1 \leftarrow\left(0.8 \mathrm{M}_{\text {max.pl.x.Rd }}\right) \text { if }\left(\mathrm{h} 1>\mathrm{M}_{\text {c.x }}\right) \\
\mathrm{h} 1 \leftarrow\left(\mathrm{M}_{\text {c.x }}\right) \text { if }\left(\mathrm{h} 1<\mathrm{M}_{\text {c.x }}\right)
\end{array} \\
& \mathrm{M}_{\mathrm{d} . \mathrm{x}}=2084.4324 \quad \mathrm{kN} \cdot \mathrm{cm} \\
& \mathrm{M}_{\text {d.y }}:=\mid \begin{array}{l}
\mathrm{h} 1 \leftarrow\left(0.8 \mathrm{M}_{\text {max.pl.y.Rd }}\right) \text { if }\left(\mathrm{h} 1>\mathrm{M}_{\text {c.y }}\right) \\
\mathrm{M}_{\text {c.y }} \text { if }\left(\mathrm{h} 1<\mathrm{M}_{\text {c.y }}\right)
\end{array} \\
& \mathrm{M}_{\text {d.y }}=1502.7068 \quad \mathrm{kN} \cdot \mathrm{cm} \\
& \mathrm{N}_{\text {pl.c.Rd }}:=\alpha \cdot A c \cdot f_{c d} \\
& \mathrm{~N}_{\text {pl.c. } \mathrm{Rd}}=609.633 \\
& \mathrm{kN}
\end{aligned}
$$

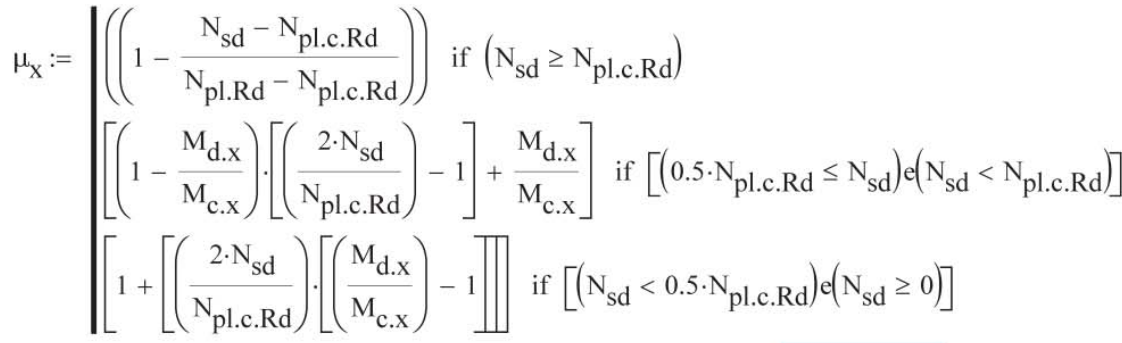

$$
\begin{aligned}
& \mu_{x}=0.5316
\end{aligned}
$$




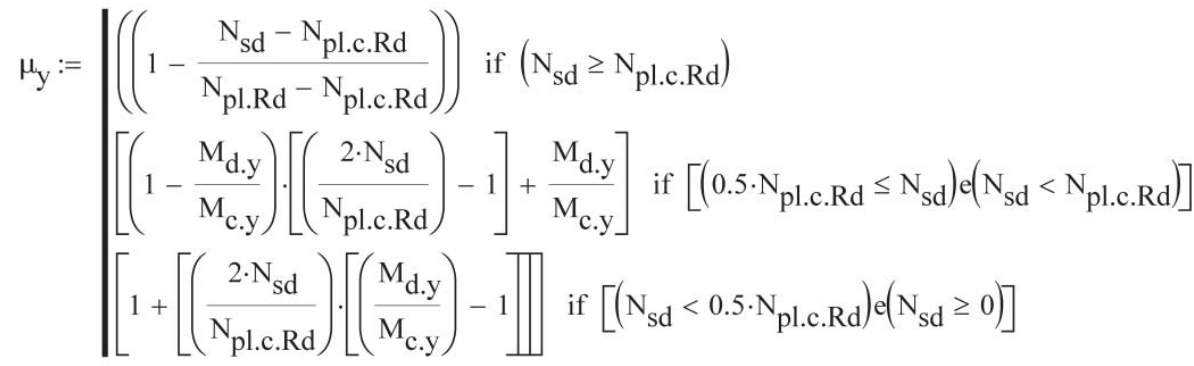

$$
\begin{aligned}
& \mu_{y}=0.5316
\end{aligned}
$$

\subsubsection{Equação de Interação}

$$
\begin{gathered}
\frac{\mathrm{N}_{\mathrm{sd}}}{\mathrm{N}_{\mathrm{Rd}}}=0.8939 \\
\left(\frac{\mathrm{M}_{\mathrm{x} \cdot \mathrm{Sd}}}{\mu_{\mathrm{x}} \cdot \mathrm{M}_{\text {c. }}}\right)+\left(\frac{\mathrm{M}_{\mathrm{y} \cdot \mathrm{Sd}}}{\mu_{\mathrm{y}} \cdot \mathrm{M}_{\text {c.y }}}\right)=0.989
\end{gathered}
$$

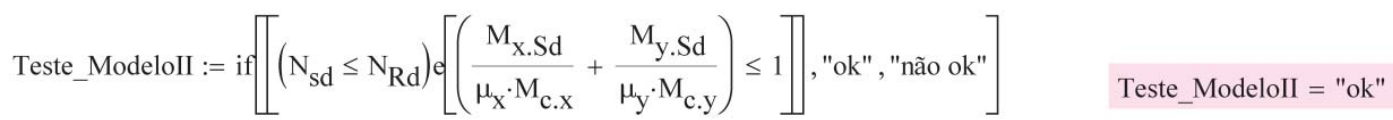

